\title{
Range Plant Community Types and Carrying Capacity for the Subalpine and Alpine Subregions
}
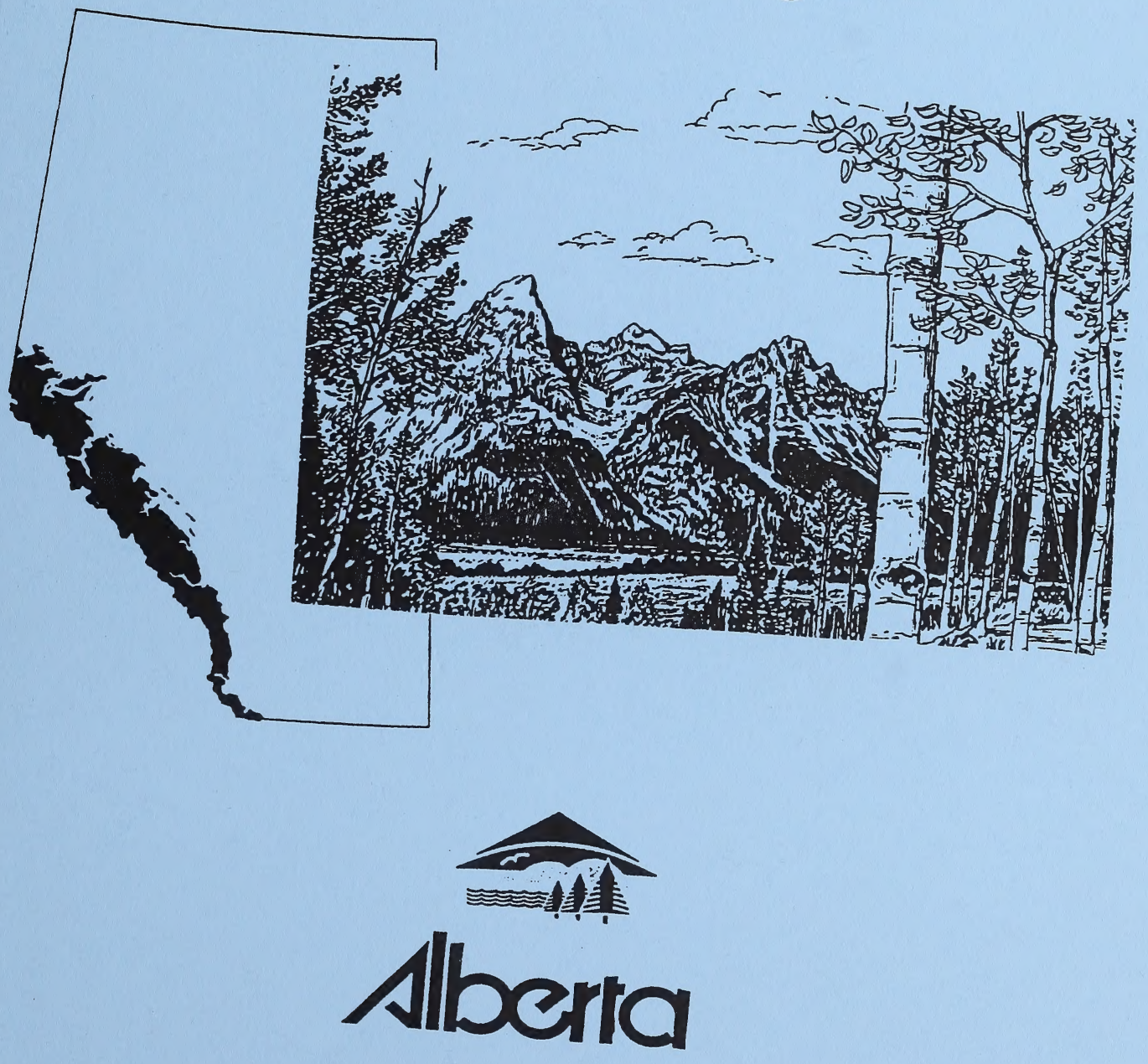

Sustainable Resource Development 


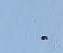

\section{-}




\title{
RANGE PLANT COMMUNITY TYPES AND CARRYING CAPACITY FOR THE SUBALPINE AND ALPINE SUBREGIONS
}

\section{Second approximation}

(Please note this edition is a revision of the $1^{\text {st }}$ approximation of the $R_{\text {an }}$ Plant Community types and carrying capacity for the Subalpine and Alpine subregions. Pub. No. $\mathrm{T} / 438)$

\section{3}

\author{
Prepared by \\ Michael G. Willoughby \\ and \\ Michael J. Alexander
}


Pub. No.: T/034

ISBN: 0-7785-2342-X

For coplus vi this report contact:

Michael Willoughby

Rm 200 J.G. O' Donoghue Bldg.

7000113 th Str.

Edmonton, Alta.

T6H 5T6

(780) 422-4598

mike.willoughby@gov.ab.ca 


\section{Table of contents}

Introduction

Climate of Subalpine and Alpine subregions

Methods

How to use guide

Results

Subalpine (Grassland and Shrubland ecology)

Central and Northern Foothills areas

Ecology of ecodistricts

Key to grasslands in the Foothills

Key to shrublands in the Foothills

Grasslands

Community types

SACFA1. Water sedge-Beaked sedge meadows $\quad 35$

SACFA2. Tufted bulrush $\quad 36$

SACFA3. Sedge-Cottongrass $\quad 37$

SACFA4. Tufted hairgrass-Sedge 38

SACFA5. Sedge-Tufted hairgrass 39

SACFA6. Sedge-Rocky Mtn. fescue-Alpine timothy 40

SACFA7. Sedge-Slender wheatgrass-Fringed brome/Forb 41

SACFA8. California oatgrass-Sedge 42

SACFA9. Rough fescue-Hairy wildrye-Sedge 43

SACFA10. Sedge-Hairy wildrye 44

SACFA11. Blunt sedge-Junegrass/Bearberry 45

SACFA12. Fringed sage/Sedge-Junegrass 46

SACFA13. Sedge-Bog sedge-Tufted hairgrass $\quad 47$

SACFA14. White Mtn. avens/Bog sedge 48

SACFA15. Creeping red fescue-Sedge 49

SACFA16. Kentucky bluegrass-Sedge/Dandelion 50

SACFA17. Fireweed-Meadow rue/Sedge-Hairy wildrye 51

Shrublands

SACFB1. Willow-Bog birch/Water sedge 52

SACFB2. Willow/Horsetail 53 
SACFB3. Willow/Graceful sedge $\quad 54$

SACFB4. Willow-Bog birch/Tufted hairgrass $\quad 55$

SACFB5. Willow-Bog birch/Clover-Dandelion 56

SACFB6. Willow-Bog birch/California oatgrass $\quad 57$

SACFB7. Willow-Bog birch/Hairy wildrye $\quad 58$

SACFB8. Bog birch/Bog sedge-Sedge $\quad 59$

SACFB9. Bog birch-Willow/Rough fescue $\quad 60$

SACFB10. Bog birch/Rough fescue-Bog sedge 61

SACFB11. Willow/Fringed brome-Sedge 62

Central and Northern Rocky Mountain areas 63

Ecology of ecodistricts 64

Key to the grasslands within the Mountain ecodistricts 68

Key to the shrublands within the Mountain ecodistricts 69

Grasslands

Community types

SACMA1. Bog sedge-California oatgrass $\quad 70$

SACMA2. Forb meadows $\quad 71$

SACMA3. Shrubby cinquefoil/Hairy wildrye $\quad 72$

SACMA4. Bearberry-Juniper 73

SACMA5. Junegrass-Hairy wildrye-Brome $\quad 74$

SACMA6. Hairy wildrye/Bearberry-Juniper 75

SACMA7. Northern wheatgrass $\quad 76$

$\begin{array}{ll}\text { SACMA8. Alpine bluegrass } & 77\end{array}$

SACMA9. Yellow mountain avens 78

Shrublands

SACMB1. Willow/Water sedge $\quad 79$

SACMB2. Willow-Bog birch/Sedge $\quad 80$

SACMB3. Willow-Bog birch/Hairy wildrye $\quad 81$

SACMB4. Willow-Bog birch/Bog sedge $\quad 82$

SACMB5. Bog birch/Juniper $\quad 83$

SACMB6. Willow/Forb $\quad 84$

SACMB7. Grouseberry-Juniper $\quad 85$

SACMB8. Subalpine fir $\quad 86$

$\begin{array}{ll}\text { Southern Rocky Mountains } & 87\end{array}$

Native grass and shrubland ecology $\quad 88$

Key to grasslands and shrublands $\quad 116$

Grasslands

Community types

North of Blairmore 
SASMA1. Water sedge

SASMA1a. Beaked sedge-Alpine foxtail-Tufted hairgrass

SASMA2. Rough fescue-Sedge

SASMA3. Rough fescue-Hairy wildrye

SASMA3a Hairy wildrye-Rough fescue-Sedge

SASMA4. Sedge-Hairy wildrye-Slender wheatgrass

SASMA5. Kentucky bluegrass/Dandelion

SASMA6. Yellow mountain avens

SASMA7. Tufted hairgrass-Sedge

SASMA7a Marsh reedgrass/Cow parsnip

South of Blairmore

SASMA8. Rough fescue-Idaho fescue-Parry oatgrass

SASMA9. Rough fescue-Sedge/Bearberry

SASMA10. Parry oatgrass-Rough fescue-Sedge

SASMA11. Sedge/Bearberry

SASMA12. Silverberry-Rose

SASMA13. Fescue-Junegrass/Early yellow locoweed

SASMA14. White Mountain avens

SASMA15. Pinegrass-Hairy wildrye/Strawberry

SASMA16. Forb meadow

Shrublands

SASMB1. Willow/Sedge

SASMB2. Willow/Richardson needlegrass 139

SASMB4. Willow-Bog birch/Rough fescue-Kentucky bluegrass $\quad 140$

SASMB5. Willow/Marsh reedgrass

Grazing modified

SASMC1. Parry oatgrass-Rough fescue-Kentucky bluegrass

SASMC2. Parry oatgrass-Kentucky bluegrass-Sedge

SASMC3. Meadow foxtail-Kentucky bluegrass

SASMC4. Fringed sage/Kentucky bluegrass-Parry oatgrass 145

SASMC5. Rough fescue-Kentucky bluegrass $\quad 146$

SASMC6. Kentucky bluegrass-Rough fescue 147

SASMC7. Timothy-Slender wheatgrass/Fireweed 148

SASMC8. Marsh reedgrass-Timothy/Cow parsnip 149

SASMC9. Idaho fescue-Rough fescue/Bearberry 150

Subalpine Forest Ecology 152

Deciduous

SASMD1 Pb/Silverberry 
SASMD2. Aw/Rose/Pinegrass

SASMD3. Aw/Fireweed/Meadow foxtail 156

SASMD4. Aw/Rose/Canada bluegrass 157

SASMD5. Aw-Pb/Cow parsnip $\quad 158$

SASMD6. Aw-Pb/Cow parsnip/Timothy 159

Conifer

SASME1. PI/Juniper $\quad 160$

SASME2. P1/Pinegrass 161

SASME3. Pl-Se/Moss $\quad 162$

SASME4. Se-Aw/Alder/Hairy wildrye 163

Alpine subregion

Ecology of Alpine communities 165

Community types

ALPA1. Bog sedge 167

ALPA2. White mountain avens 168

$\begin{array}{ll}\text { ALPA3. Mountain heather } & 169\end{array}$

ALPA4. Blackening sedge $\quad 170$

ALPA5. Simple bog sedge $\quad 171$

ALPA6. Arctic willow (low willow types) 172

$\begin{array}{ll}\text { Literature cited } & 173\end{array}$

\section{List of Figures}

Figure 1. Overview of native shrub and grassland complex in the Central and Northern Foothills 28

Figure 2. Grassland and shrubland community types in the landscape of the Central and Northern Rocky Mountain and Foothills areas of the Subalpine subregion

Figure 3. Overview of native shrub and grassland complex in the Central and Northern Rocky Mountains

Figure 4. Sequence of plant communities in the upper Subalpine and Alpine subregions of Alberta

Figure 5. Overview of native shrub and grassland complex in the Southern Rocky

Mountains

Figure 6. Grassland and shrubland community types in the landscape of the Montane and Subalpine subregions of southern Alberta

Figure 7. Aspen/Rose/Pinegrass dominated community type in the southern zone of the Subalpine subregion

Figure 8. Overview of native shrub and grassland complex in the Alpine 
subregion

\section{List of Tables}

Table 1. Ecosites, ecosite phases and plant community types for the Subalpine subregion of West-Central Alberta(adapted from Beckingham et al. 1996).

6

Table 2. Native grass and shrublands of the Central and Northern Foothills

Table 3. Native grass and shrublands of the Central and Northern Rocky Mountains

Table 4. Ecosites, ecosite phases and plant community types for the Subalpine subregion of Southern Alberta(adapted from Archibald and Klappstein 1996).

Table 5. Native grass and shrublands of the Southern Rocky Mountains

Table 6. Deciduous and conifer communities for the Southern Rocky Mtn. ecodistrict of the Subalpine subregion 153

Table 7. Native grasslands and shrublands of the Alpine subregion 166

\section{List of Maps}

Map 1. Location of Alpine and Subalpine subregions in Alberta 


\begin{abstract}
The Subalpine subregion is a Rocky Mountain altitudinal vegetation zone extending from an elevation of $1575 \mathrm{~m}$ to $2175 \mathrm{~m}$ at its southernmost occurrence and $1365 \mathrm{~m}$ to $2000 \mathrm{~m}$ near Grande Cache (Strong 1992). The valley bottoms of the subalpine are extensively utilized for recreational horseback riding and commercial trail riding operations. As a result many of the grass and shrublands around the back country campsites are extensively utilized by horses. This utilization has an impact on the vegetation which can be detrimental to the wildlife populations in the area. Despite the importance of these vegetation types for wildlife and backcountry horse use there is little information on their ecology. The lack of information makes it difficult to development management prescriptions for multiple use. The Alpine subregion which occurs above the upper climatic forest-line in the Rocky Mountains (Strong 1992) overlaps with many of the subalpine community types and therefore can be important locally for wildlife. As a result this guide was developed for the Subalpine and Alpine subregions in order to provide a framework that will easily group the vegetative community types. It is hoped this classification system can be used by field staff to assess the ecology of the sites and develop management prescriptions on lands within each region. This guide represents the analysis of 651 plots described in the Subalpine subregion and 134 grass and shrubland plots described in the Alpine subregion. In the Subalpine subregion it was found there was distinct differences between the grassland and shrubland community types between the Central and Northern Foothills (West of Rocky Mountain house and Hinton), the Central and Northern Rocky Mountains (Banff and Jasper National Parks) and the Southern Rocky Mountains (southwest of Calgary). As a result the Subalpine was prestratified into 3 subdivisions. These types are split into:
\end{abstract}

\title{
Subalpine
}

Central and Northern Foothills
A. Native grasslands
17 community types
B. Native shrublands
11 community types

Central and Northern Rocky Mountains
A Native grasslands
B. Native shrublands
9 community types
8 community types

Southern Rocky Mountains
A. Native grasslands
19 community types
B. Native shrublands
C. Grazed grasslands
D. Deciduous
E. Conifer
5 community types
9 community types
6 community types
4 community types

\section{Alpine}

A. Native grasslands and shrublands 6 community types

The dominant plant species, canopy cover, environmental conditions, response to grazing, forage production and carrying capacity are outlined for each type. 


\section{Acknowledgements}

The creation of this report would not be possible without the data collected in other projects. We would like to acknowledge Parks Canada for allowing us to use data from the Ecological Land Classification of Banff and Jasper National Parks (Holland and Coen 1982). Much of the grass and shrubland vegetation data collected by Ian Corns and Peter Achuff for this project were incorporated into this guide. We would also like to acknowledge the Alberta Conservation Association and Corporate Management Service. They provided funding for the study of bighorn sheep winter range in Southern Alberta and backcountry horse use and elk carrying capacity in the Panther Corners. The vegetation data from these studies were also included in this guide. Finally appreciation and thanks go out to all members and former members of Land and Forest Service who were involved in data collection. 



\section{Introduction}

The province of Alberta is covered by a broad spectrum of vegetation regions from prairie in the South, to alpine vegetation in the mountains and dense forests in the Central and Northern part of the province. These broad vegetation regions have been classified into 6 regions and 20 subregions (Dept. of Environmental Protection 1994). Each of the 20 subregions consists of groups of plant communities which are influenced by environmental conditions and human impacts. Intensive management of these regions requires the ability to recognize the vegetative communities that have similar productivities and respond to disturbance in the same way.

The purpose of this guide was to develop a framework that would easily group the grassland and shrubland community types in the Subalpine and Alpine subregions of the province. Initially the guide was developed to provide a classification system that could be ust. by the field staff to assess carrying capacity and evaluate range condition on back country areas within the foothills of the Subalpine subregion, but it was realized that these community types were only transitional to subalpine and alpine communities described by Ogilvie (1969) and Corns and Achuff (1982). As a result, their original data was reclassified and added to the more recent data to form a more detailed classification.

It is hoped this classification system can be used by field staff to assess the ecology of the sites and develop management prescriptions on lands within the region. This guide supplements the work done by Beckingham et al. (1996), Beckingham and Archibald (1996) and Archibald et al. (1996) on the forested community types in the Subalpine subregion. Their guides are a good description of the forested community types found within the subregion, but it does not include forage production values and carrying capacities. It also does not provide a description of the native shrubland and grassland communities which are utilized by livestock at the lower elevations in this subregion.

The sections of the guide that describes the Central and Northern Rocky Mountain areas of the Subalpine and the Alpine subregions supplements the work done by Corns and Achuff (1982) in Banff and Jasper National Parks.

\section{Climate}

\section{Subalpine subregion}

The subalpine subregion is a Rocky Mountain altitudinal vegetation zone with its upper boundary formed by the Alpine subregion, whereas the lower boundary abuts the Montane, Foothills parkland and the Upper Foothills subregions. In Alberta, the subalpine extends from $1525 \mathrm{~m}$ to $2175 \mathrm{~m}$ at its southernmost occurrence and from $1360 \mathrm{~m}$ to $2000 \mathrm{~m}$ in the vicinity of Grande Cache (Strong 1992). The subalpine has a cordilleran climate characterized by snowy, cold winters and showery cool summers. Annual precipitation ranges from $329 \mathrm{~mm}$ to $916 \mathrm{~mm}$, with maximum precipitation falling during July. The subalpine recieves more precipiatiton during the winter months than any subregion (Strong 1992). The mean summer temperatures averages $9.4{ }^{\circ} \mathrm{C}$ and winter temperatures typically average $-8.9^{\circ} \mathrm{C}$ with December and January being the coldest months. The cold winter temperatures help to maintain the snowpack which 
makes this an important watershed area.

The majority of the vegetation is dominated by seral lodgepole pine forests at lower elevations with Engelmann spruce and subalpine fir forests being more common at higher elevations. At timberline dwarf spruce, subalpine and whitebark pine are typical of the transition to the Alpine subregion. Imperfectly drained bottomlands are dominated by willow, bog birch, sedge, tufted hairgrass and california oatgrass species and the steep south facing slopes are often dominated by fescue, hairy wildrye, wheatgrass and junegrass species.

\section{Alpine subregion}

The Alpine subregion occurs above timberline in the Rocky Mountains of Alberta. Elevationally, alpine occupies areas greater than $2150 \mathrm{~m}$ in southern Alberta and declines to 2000 $\mathrm{m}$ in more northern portions. It is felt that the total annual precipitation is at least equal to the Subalpine subregion, which potentially makes the Alpine the wettest subregion in Alberta (Strong 1992). Summer temperatures are the coldest in Alberta with July mean temperatures averaging $10{ }^{\circ} \mathrm{C}$. Freezing temperatures occur in all months of the year. Winter temperatures are probably colder than the subalpine subregion with temperatures probably never going above freezing for the whole winter. The cold temperatures help to maintain the snowpack for much of the year. Wind is also extremely important climatic factor in the Alpine. Although, precipitation is abundant the strong winds likely result in very large moisture deficits (Strong 1992).

The Alpine is characterized by low growing vegetation, which helps to protect the vegetation from the dessicating winds, and allows the plants to gain heat from the ground. Glaciers occur at the higher elevations where snow accumulation exceeds melt. 


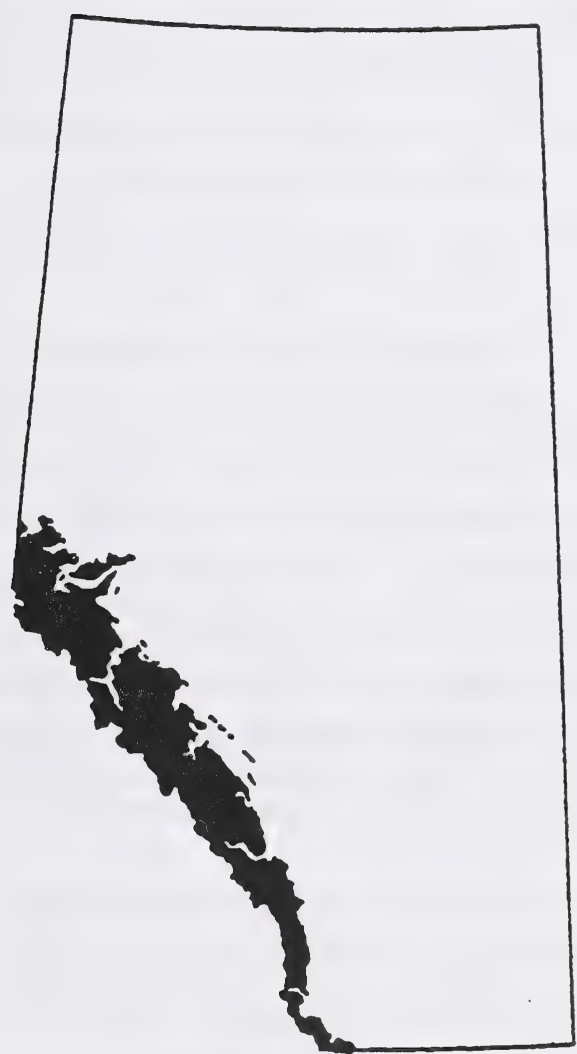

Map 1. Location of Subalpine and Alpine subregions in Alberta 


\section{Methods}

A community type approach (Mueggler 1988) to classification was chosen in preference to the habitat type approach (Daubenmire 1952) or ecosystem association approach (Corns and Annas 1986) because of the lack of understanding of the successional sequences of the communities. Community types are aggregates of similar plant communities based upon existing floristics regardless of successional status (Mueggler 1988). Community types are what is actually seen in the field. After defining the community types, they then can be linked to the ecosystem associations developed by Corns and Annas (1986) and Beckingham et al. (1996). In the mean time community types can be used as the basis for mapping and range management planning.

Individual plots were initially classified within a forest region using cluster analysis (SAS) and ordination (DECORANA, Gauch 1982). These types were described in individual carrying capacity guides for each forest. This led to differences in classification of the same types between forests, particularly for deciduous forest types. In an effort to standardize the community name and gain some understanding of each community types ecology, all plots sampled in each forest were reclassified. As the study progressed it became quite evident that there were differences in the productivity of the communities between subregions. As a result, it was decided to develop the classification within the subregion framework. A subregion is a geographical area that has broad vegetation zones combined with climatic data. As a result, the vegetation within each subregion is strongly influenced by the climatic conditions.

Sampling for this guide occurred within the Subalpine and Alpine subregions. This guide outlines the preliminary classification of 651 plots described in the Subalpine and 134 plots described in the Alpine subregion.

The procedure for inventory in the Southern Rocky Mtn. and Central and Northern Foothills areas followed the Range Survey Manual (1992) and uses the MF5 form. A plot consisted of a 10x10 m macroplot and ten randomly selected $1 \times 1 \mathrm{~m}$ microplots to record the canopy cover of shrubs and ten nested 20x50 cm microplots to record the canopy cover of forbs and grass. At each macroplot a 50x100 cm was clipped and separated into trees, shrubs, forbs and graminoids, oven dried and weighed. The recommended stocking rate is based on 25 percent of the total production for forested types and $50 \%$ total production for grass and shrubland types and the fact that one animal requires $455 \mathrm{~kg}$ of dry weight material for one month of grazing.

For a description of the methodology for the remaining plots done in the Central and Northern Rocky Mountains of the Subalpine and Alpine subregions see Holland and Coen (1982).

\section{How to use the guide}

In the Subalpine subregion it was found there was distinct differences between the grassland and shrubland community types between the Central and Northern Foothills (the foothills west of Sundre, Rocky Mtn. House, Hinton and Grande Cache), the Central and Northern Rocky 
Mountains (mountains of Banff and Jasper National Park) and the Southern Rocky Mountains (foothills west of Calgary, Turner valley and areas south of Blairmore) (Strong and Thompson 1995). As a result the Subalpine was prestratified into 3 subdivisions. For the Subalpine first decide which area you are in then turn to the appropriate subdivision in the guide. The Alpine is generally all the vegetation types above timberline.

In order to understand how the community types in this guide are related to the ecosites and ecosite phases outlined in "Ecosites of West-Central Alberta and Southwestern Alberta" (Beckingham et al. 1996, Archibald et al. 1996), the community types in this guide are arranged by ecosite and ecosite phase for West-Central Alberta (Table 1) and Southwestern Alberta (Table 4). Ecosites are defined as ecological units that develop under similar environmental influences (climate, moisture and nutrient regime). An ecosite phase is a subdivision of the ecosite based on the dominant species in the canopy. Table 1 is a reproduction of Figure 20 in the Ecosites of West-Central Alberta guide and table 4 is a reproduction of Figure 20 in the Ecosites of Southwestern Alberta guide with the community types in this guide highlighted. For the most part the ecosites and ecosite phases are the same, particularly for the forested community types, but a number of new ecosites and ecosite phases had to be created for the grass and shrubland community types (Table 1). The ecosites included (bb)(subxeric/poor) yellow mountain avens, and (dd)(subhygric/medium) bog sedge meadow. The ecosite phases include (b2) bearberry grassland, (bb1) yellow mtn. avens, (c4) hairy wildrye grassland, (d4) California oatgrass, (d5) willow, (d6) grouseberry, (dd1) sedge-bog sedge, (dd2) shrubland, (e3) grass meadow, (g2) willow and (h3) grass bog for West-Central Alberta (Table 1). In Southwestern Alberta the new ecosites include (cc) (submesic/rich) rough fescue, and (i) fen. The ecosite phases included (a2) grassland, (b2) grassland, (c2) yellow mtn. avens, (cc1) rough fescue, (cc2) shrubland, (cc3) forb meadow, (f3) thimbleberry Aw, (f4) shrubby seepages, (i1)shrub fen and (i2) graminoid fen (Table 4). The "Grazing succession" category outlines the successional sequence the community type will undergo with increased grazing pressure. For a detailed description of the forested community types in the Subalpine please refer to the work done by Beckingham et al. (1996), Beckingham and Archibald (1996) and Archibald and Klappstein (1996). The dominant plant species, canopy cover, environmental conditions, response to grazing, forage production and carrying capacity of the grasslands and shrublands for the Subalpine and Alpine subregions are outlined in this guide. 


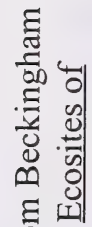

웅요

율

흘

胥

픈

है

$\frac{1}{5}$

3

48

응

क्ष

के

0

응

के ซึ

号

อั

\& $\Xi$

¿

.

छ ฮ

हี ซี

¿ֶ)

ป

.

过 홍

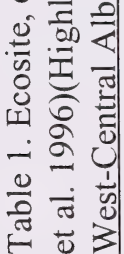

\begin{tabular}{|c|c|c|c|c|c|c|c|c|c|c|}
\hline 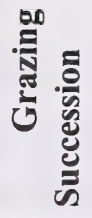 & & & & & & & & & & \\
\hline 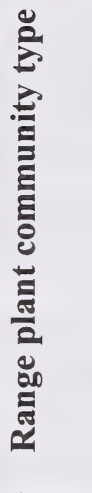 & 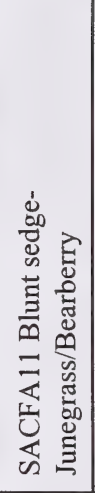 & 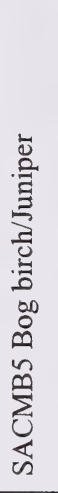 & 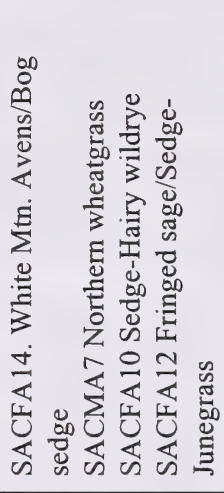 & & & & 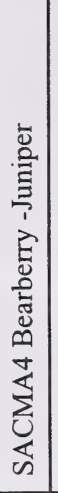 & 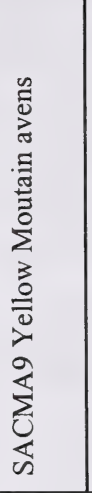 & & \\
\hline 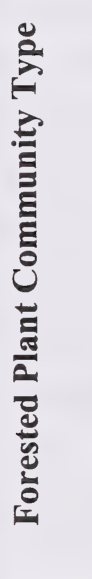 & 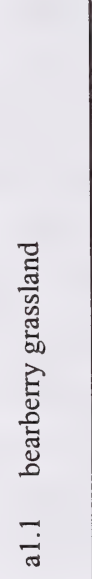 & 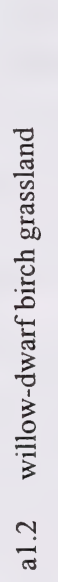 & 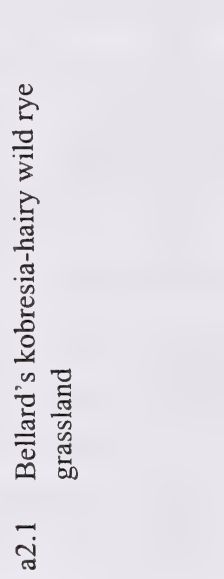 & 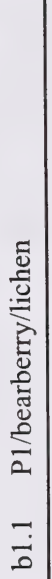 & 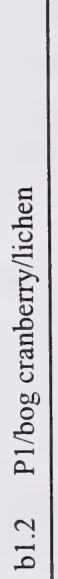 & 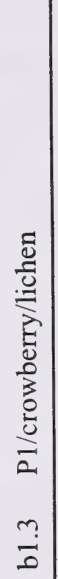 & & & 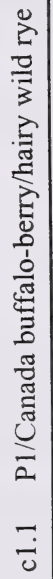 & 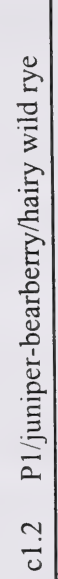 \\
\hline 总 & 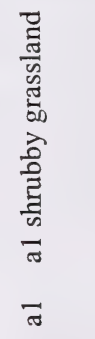 & & 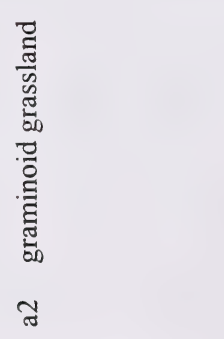 & 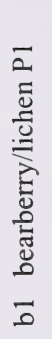 & & & 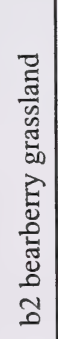 & 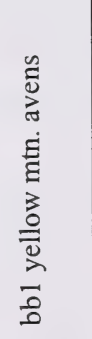 & 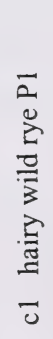 & \\
\hline 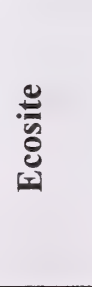 & 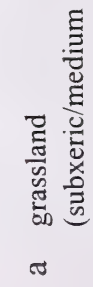 & & & 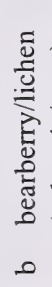 & & & & 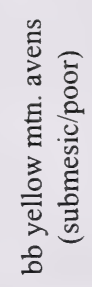 & $\sum_{0}^{\frac{0}{3}}$ & 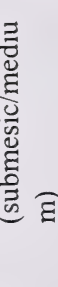 \\
\hline
\end{tabular}




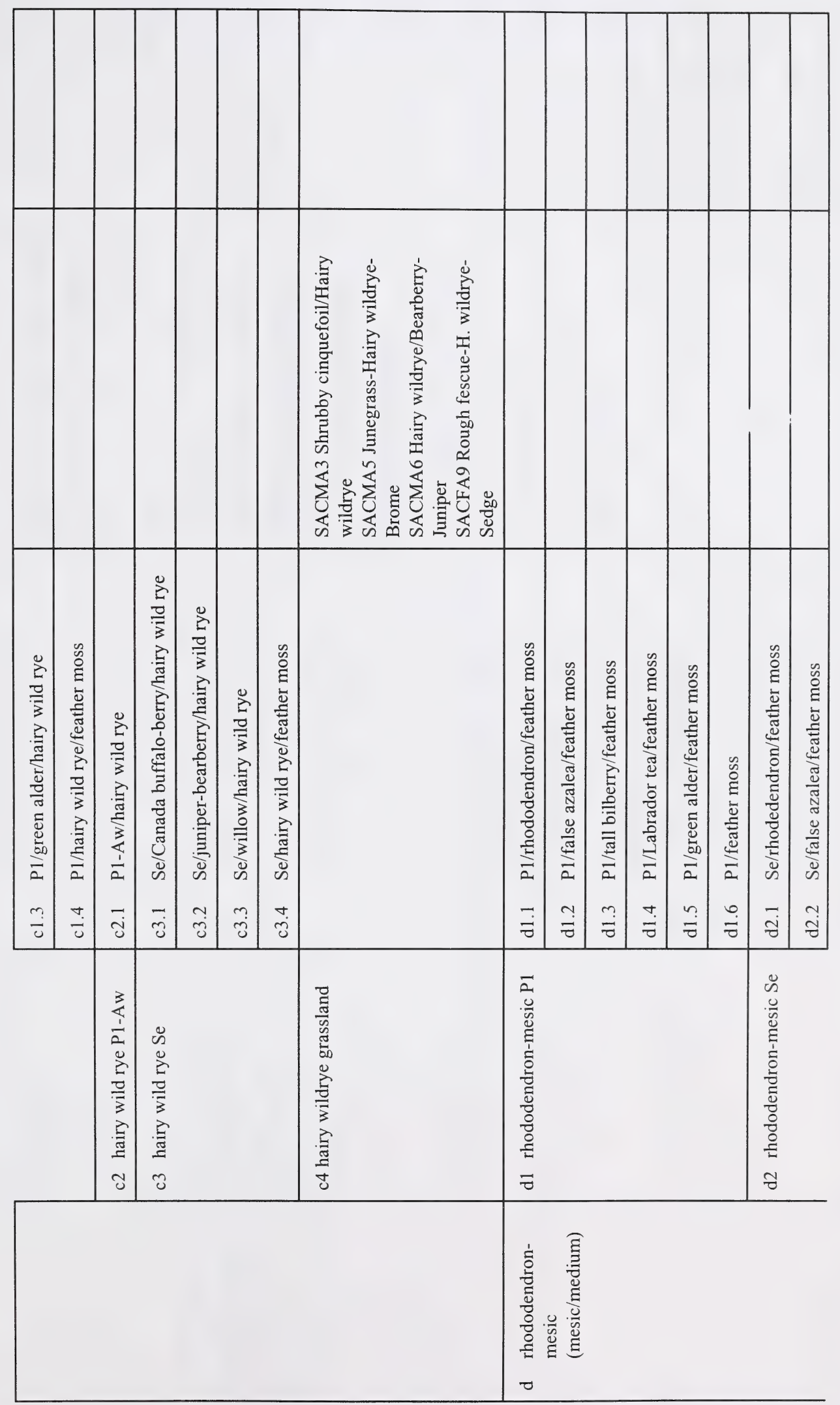




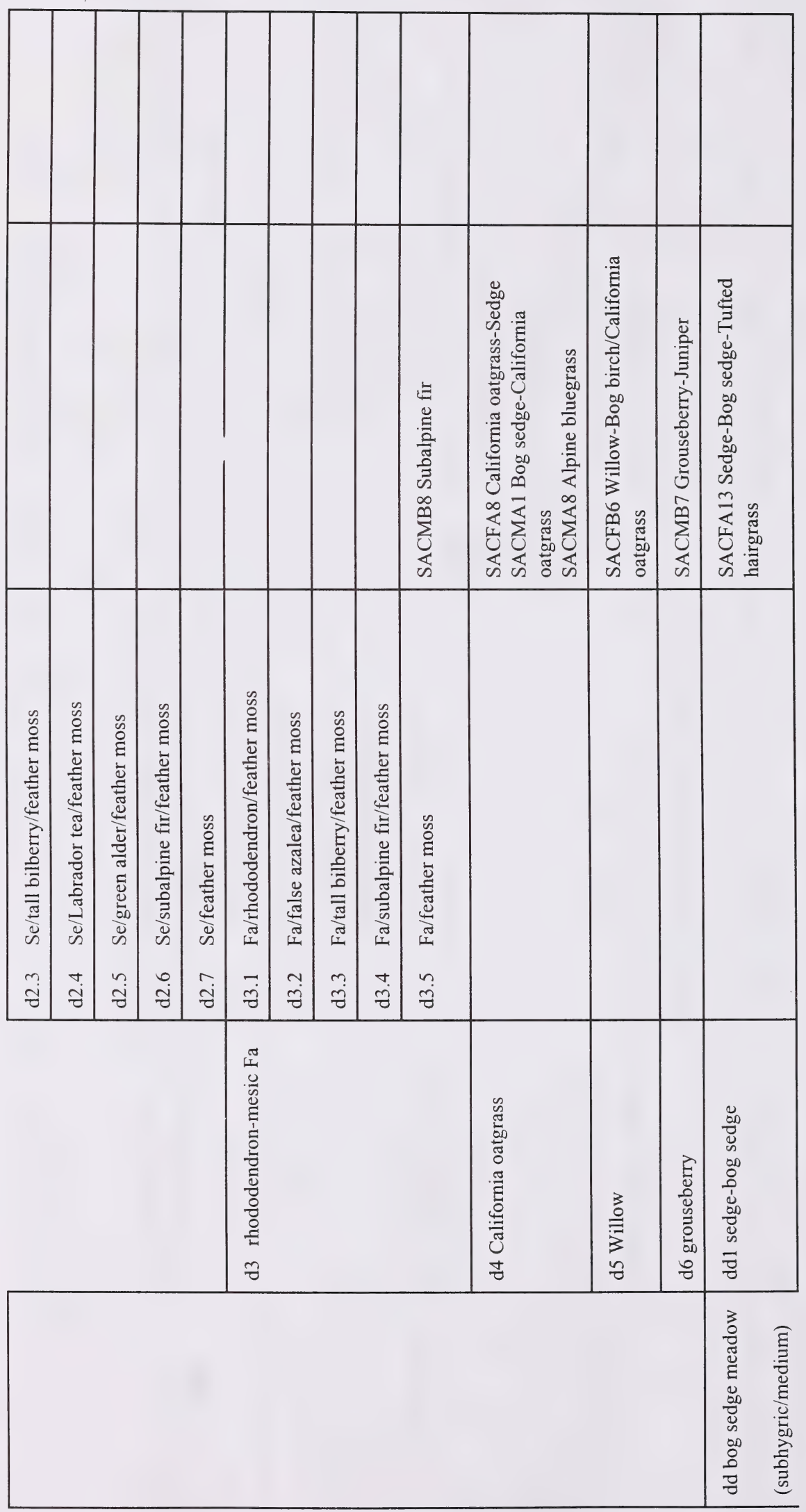




\begin{tabular}{|c|c|c|c|}
\hline & 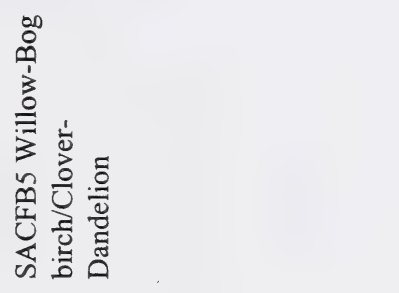 & & 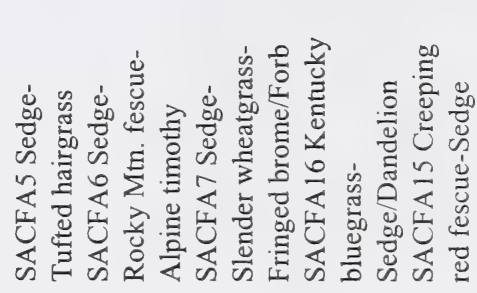 \\
\hline 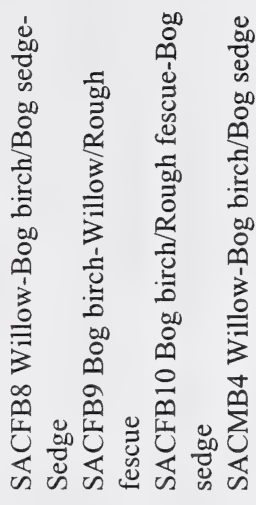 & 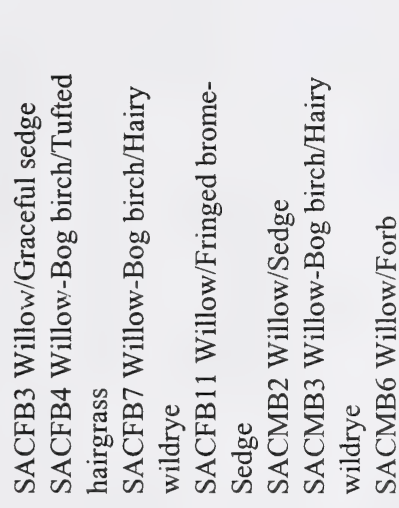 & 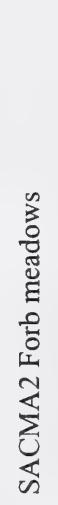 & 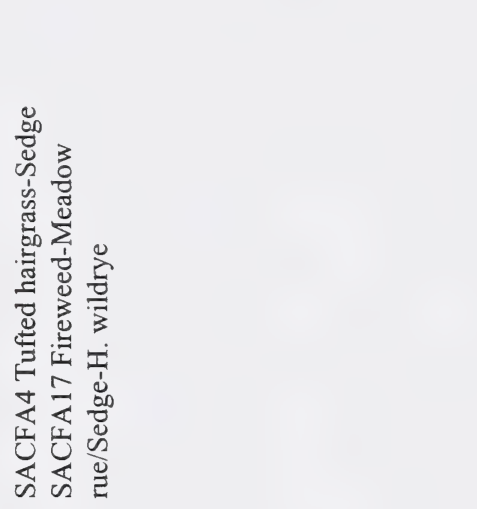 \\
\hline & 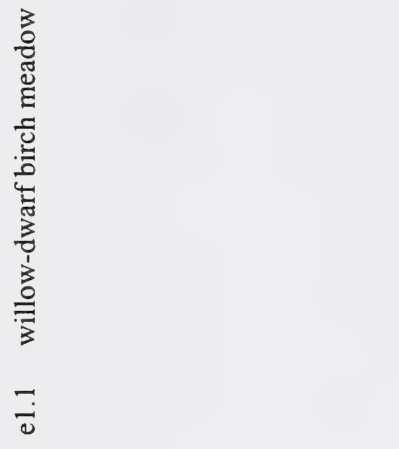 & 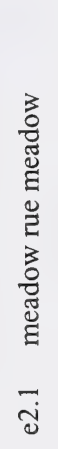 & \\
\hline 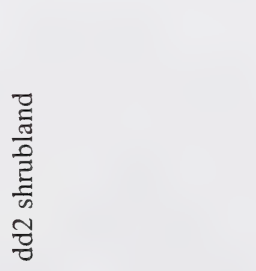 & 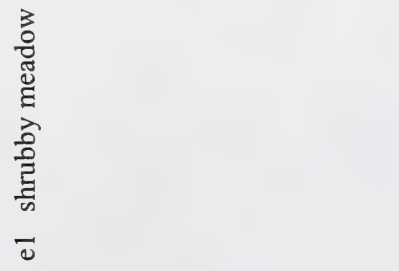 & 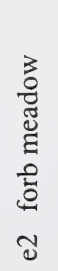 & 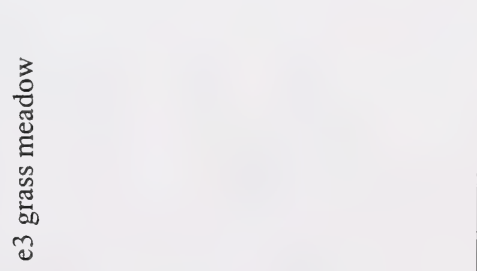 \\
\hline & 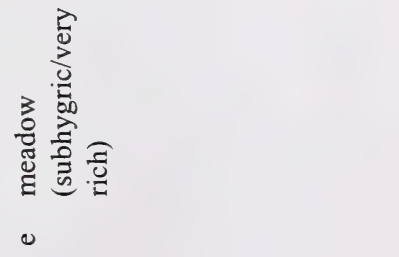 & & \\
\hline
\end{tabular}




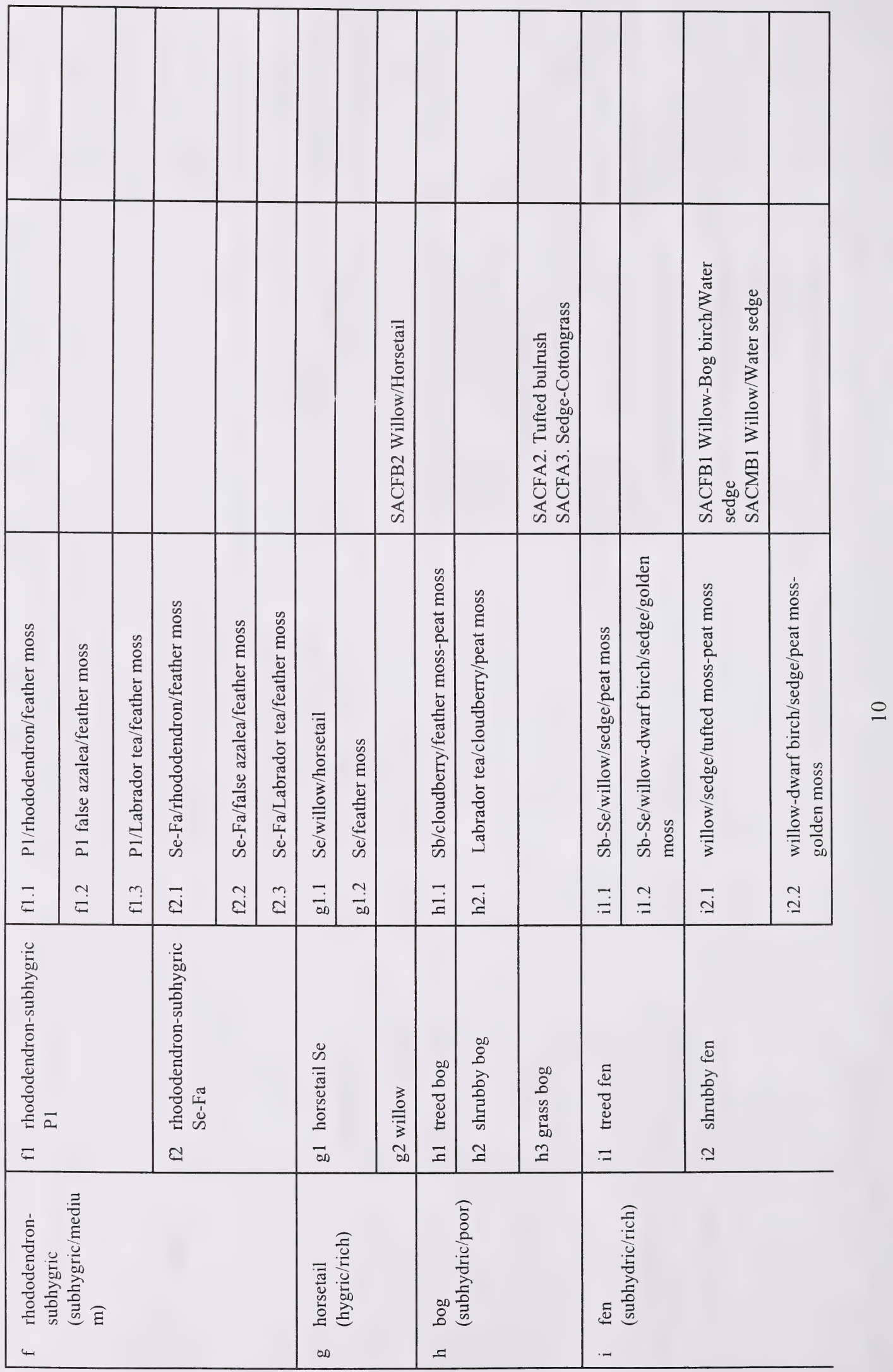




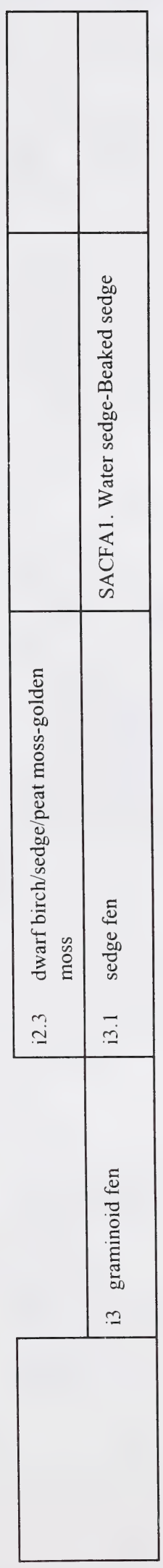




\section{b2 bearberry grassland $(n=9)$}

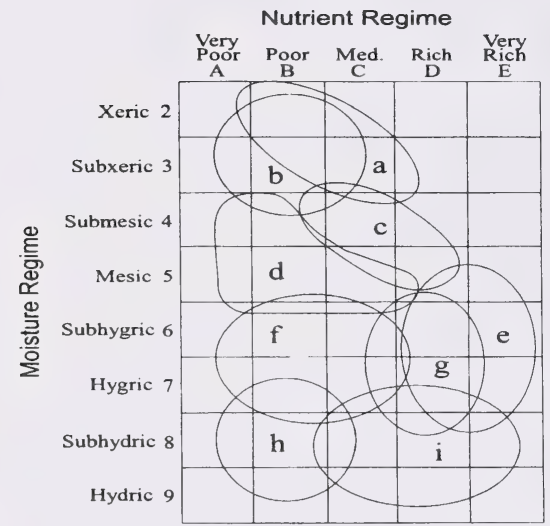

\section{SITE CHARACTERISTICS}

Moisture regime: subxeric, mesic

Nutrient regime: poor, medium

Topographic position: upper slope

Slope: (16-30)(46-70)

Aspect: southerly

\section{SOIL CHARACTERISTICS}

Organic thickness: $(0-5)$

Humus form: mor

Surface texture: SL,S,L

Effective texture: SL, LS

Depth to Mottles/Gley: none

Diainage: rapid, well

Parent material: $\mathrm{M}, \mathrm{GF}$

Soil subgroup:, E.DYB, O.HFP, BR.GL, O.EB

\section{COMMUNITY TYPES}

SACMA4. Bearberry-Juniper $(n=9)$

\section{CHARACTERISTIC SPECIES}

Trees

[2] Aspen

\section{Shrubs}

[4] Willow

[2] White mtn. avens

[4] Shrubby cinquefoil

[11] Ground juniper

Forbs

[16] Bearberry

[2] White camas

[1] Strawberry

[1] Yarrow

\section{Graminoids}

\section{[2] Sedge}

[1] Spiked trisetum

[3] Hairy wildrye 


\section{subxeric/medium}

\section{GENERAL DESCRIPTION}

This ecosite is located on recent fluvial and glacialfluvial landforms with gentle slopes. The soils are poorly developed gravels and are rapidly drained. Yellow mountain avens, bearberry, juniper and junegrass are typical of these early successional river flats. The poor soil conditions limits the forage productivity and amount of regrowth after grazing. This ecosite should be rated as non-use range.

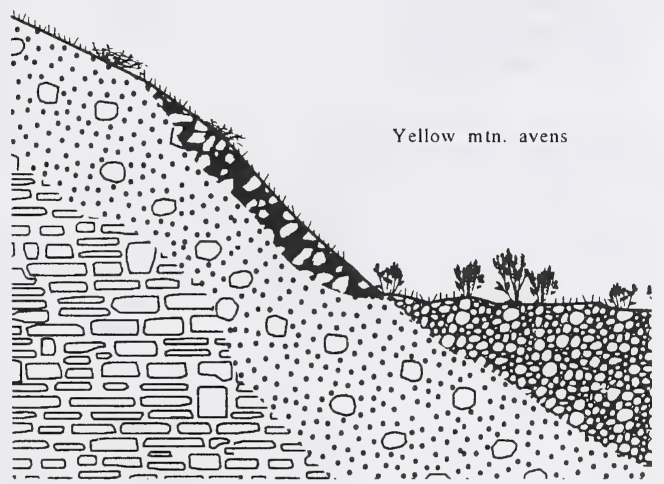

\section{SUCCESSIONAL RELATIONSHIPS}

Yellow mtn. avens generally dominates this community in the early successional stages. Succession in the absence of disturbance will be to balsam poplar, Engelmann spruce and subalpine fir.

\section{INDICATOR SPECIES}

yellow mtn. avens

willow

silverberry

juniper

showy locoweed

bearberry

alpine fireweed

sedge

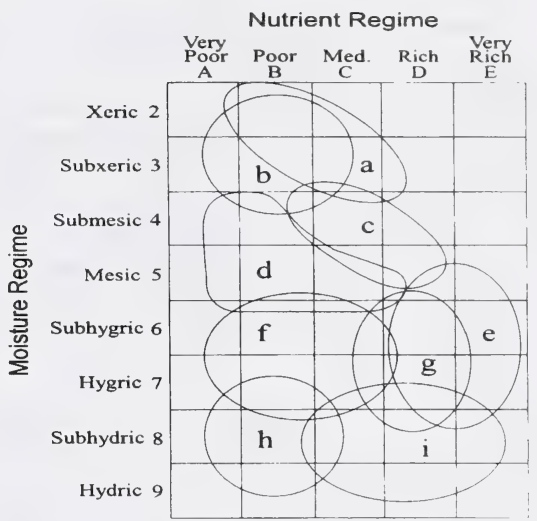

\section{SITE CHARACTERISTICS}

Moisture regime: subxeric, submesic

Nutrient regime: poor, medium

Topographic position: floodplain

Slope: (0-5)

Aspect: variable

\section{SOIL CHARACTERISTICS}

Organic thickness: $(0-2)$

Humus form: mor

Surface texture: SL, SiL

Effective texture: SL,

Depth to Mottles/Gley: none

Drainage: rapid, well

Parent material: F, GF

Soil subgroup:, O.R

\section{ECOSITE PHASES}

bbl yellow mtn. avens $(n=4)$ 
bb1 yellow mtn. avens $(n=4)$

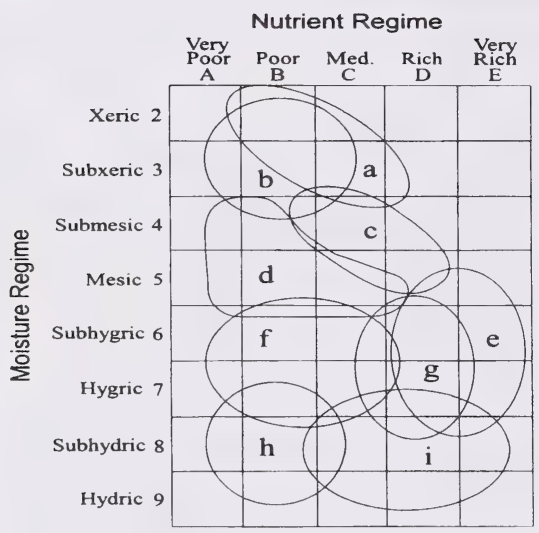

\section{SITE CHARACTERISTICS}

Moisture regime: subxeric, submesic

Nutrient regime: poor, medium

Topographic position: floodplain

Slope: $(0-5)$

Aspect: variable

\section{SOIL CHARACTERISTICS}

Organic thickness: $(0-2)$

Humus form: mor

Surface texture: SL,SiL

Effective texture: SL,

Depth to Mottles/Gley: none

Drainage: rapid, well

Parent material: F, GF

Soil subgroup:, O.R

\section{COMMUNITY TYPES}

SACMA9. Yellow mountain avens $(n=4)$

\section{CHARACTERISTIC SPECIES}

\section{Trees}

[2] Engelmann spruce

[1] Subalpine fir

[1] White spruce

\section{Shrubs}

[5] Willow

[1] Buffaloberry

[50] Yellow mtn. avens

[1] Shrubby cinquefoil

\section{Forbs}
[1] Alpine fireweed
[1] Showy locoweed
[1] Alpine goldenrod

\section{Graminoids}
[1] Sedge
[1] Spiked trisetum 


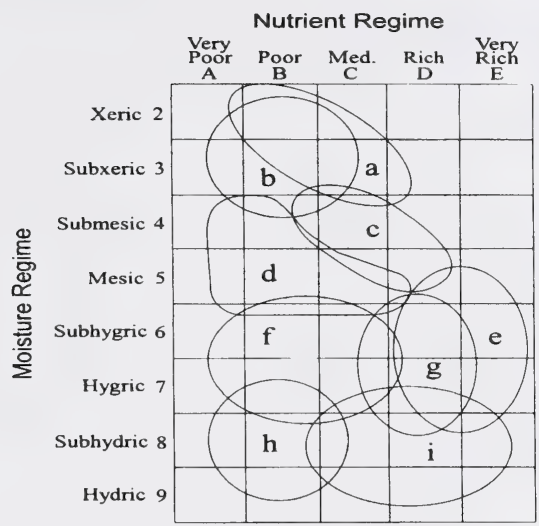

Moisture regime: subxeric, submesic,

Nutrient regime: medium

Topographic position: upper slope

Slope: (16-30)(47-70)

Aspect: southerly

\section{SOIL CHARACTERISTICS}

Organic thickness: $(0-2)(2-5)$

Humus form: no data

Surface texture: SiL

Effective texture: SL,

Depth to Mottles/Gley: none

Drainage: rapid, well

Parent material: $M$

Soil subgroup:, O.R, O.EB

\section{COMMUNITY TYPES}

SACMA3 Shrubby cinquefoil/Hairy wildrye $(n=5)$ SACMA5 Junegrass-Hairy wildrye-Brome $(n=19)$ SACMA6 Hairy wildrye/Bearberry-Juniper $(n=44)$ SACFA9 Rough fescue-Hairy wildrey-Sedge $(n=13)$

\section{Shrubs}

[2] Juniper

[10] Shrubby cinquefoil

Forbs

[9] Bearberry

[2] Showy locoweed

[2] Strawberry

[1] Old man's whiskers

[1] White mtn. avens

[1] Yellow hedysarum

\section{Graminoids}

[5] Rough fescue

[15] Hairy wildrye

[5] Sedge

[ 5 ] Junegrass 


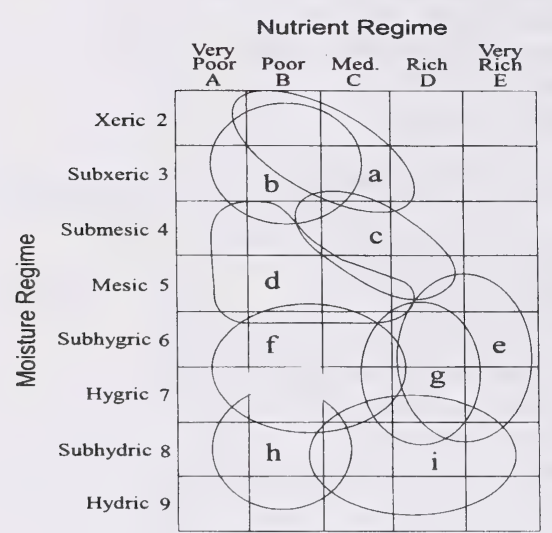

\section{CHARACTERISTIC SPECIES}

\section{Shrubs}

[11] Willow

[13] Shrubby cinquefoil

\section{Forbs}

[5] Bearberry

[3] Veiny meadow rue

[8] Strawberry

[2] Yarrow

[2] Slender blue beardtongue

[1] Fireweed

\section{Graminoids}

[30] California oatgrass

[3] Hairy wildrye

[8] Sedge

[9] Bog sedge

[15] Alpine bluegrass

\section{SITE CHARACTERISTICS}

Moisture regime: mesic, subhygric, submesic,

Nutrient regime: medium, rich, poor

Topographic position: level, midslope

Slope: $(0-5)$

Aspect: variable

\section{SOIL CHARACTERISTICS}

Organic thickness: $(0-2)(2-5)$

Humus form: no data

Surface texture: SiL, L

Effective texture: SL, SiL, L

Depth to Mottles/Gley: none

Drainage: mod. well, well

Parent material: $M$

Soil subgroup:, O.R, O.EB, BR.GL

\section{COMMUNITY TYPES}

SACFA8 California oatgrass-Sedge $(\mathrm{n}=5)$

SACMA1 Bog sedge-California oatgrass $(n=1)$

SACMA8 Alpine bluegrass $(n=1)$ 


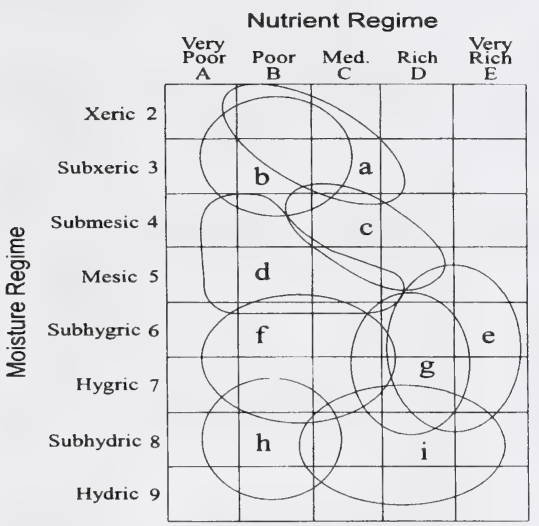

Moisture regime: mesic, subhygric, submesic,

Nutrient regime: medium, rich, poor

Topographic position: level, midslope

Slope: $(0-5)$

Aspect: variable

\section{SOIL CHARACTERISTICS}

Organic thickness: $(0-2)(2-5)$

Humus form: no data

Surface texture: SiL, L

Effective texture: SL, SiL, L

Depth to Mottles/Gley: none

Drainage: mod. well, well

Parent material: $M$

Soil subgroup:, O.R, O.EB, BR.GL

\section{COMMUNITY TYPES}

SACFB6 Willow-Bog birch/California oatgrass $(n=19)$

\section{CHARACTERISTIC SPECIES}

\section{Shrubs}

[30] Willow

[7] Bog birch

\section{Forbs}

[1] Graceful cinquefoil

[1] Veiny meadow rue

[9] Strawberry

[2] Yarrow

[2] Globeflower

[1] Wandering daisy

\section{Graminoids}

[24] California oatgrass

[4] Mountain timothy

[10] Sedge

[1] Slender wheatgrass

[1] Spiked trisetum 


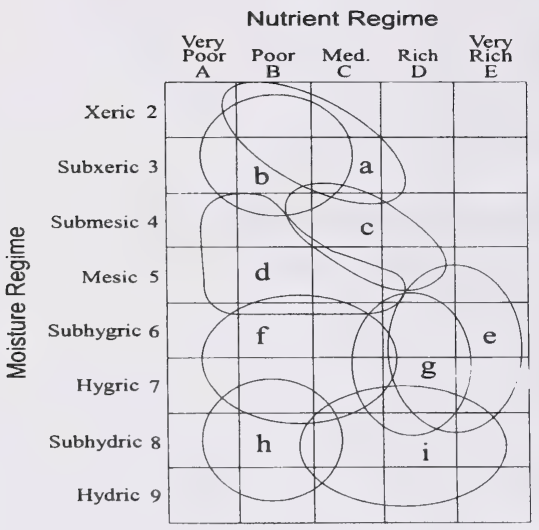

\section{CHARACTERISTIC SPECIES}

Trees

[1] Subalpine fir

Shrubs

[1] Willow

[14] Grouseberry

[5] Ground juniper

[1] Crowberry

\section{Forbs}

[12] Fireweed

[3] Small lv'd everlasting

[3] Strawberry

[2] Yarrow

\section{Graminoids}

[6] California oatgrass

[1] Sedge

[7] Spiked trisetum
Moisture regime: mesic, submesic,

Nutrient regime: medium

Topographic position: level, midslope

Slope: (0-5)

Aspect: variable

\section{SOIL CHARACTERISTICS}

Organic thickness: $(0-2)(2-5)$

Humus form: no data

Surface texture: SiL, L

Effective texture: SL, SiL, L

Depth to Mottles/Gley: none

Drainage: mod. well, well

Parent material: $M$

Soil subgroup:, O.R, O.EB, BR.GL

\section{COMMUNITY TYPES}

SACMB7 Grouseberry-Juniper $(n=4)$ 
veiny meadow rue

sedge

\section{subhygric/medium}

\section{GENERAL DESCRIPTION}

This ecosite is located on moist well drained lowland sites adjacent to rivers and streams at higher elevations in the Central and Northern Foothills of the Subalpine. The presence of bog sedge appears to indicate the transition to the higher Alpine subregion. Indeed, Oglivie (1969) described bog sedge dominated community types on windswept ridges at higher elevations in the Alpine subregion. The forage production of this community is only moderate. Perhaps, the higher elevation and colder climate which favours the growth of bog sedge limits total

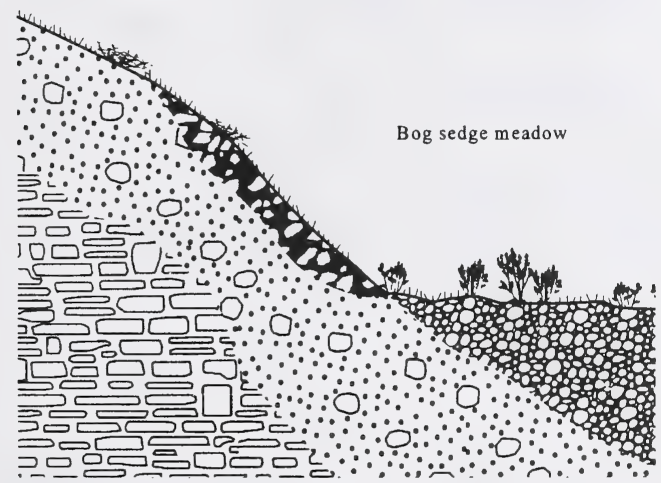

productivity of this site

\section{SUCCESSIONAL RELATIONSHIPS}

Due to the nature of the site grasslands often remain the climax vegetation on these sites. In the absence of disturbance willow and bog birch often invade to form willow and bog birch dominated shrublands.

\section{INDICATOR SPECIES}

california oatgrass

bog sedge rough fescue tufted hairgrass sedge willow bog birch

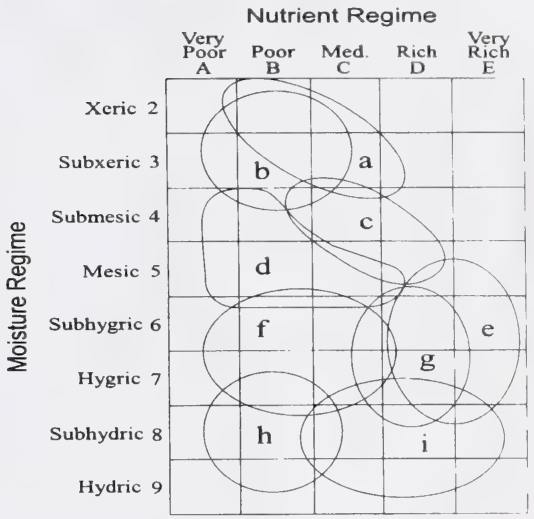

\section{SITE CHARACTERISTICS}

Moisture regime: mesic, subhygric

Nutrient regime: medium, rich

Topographic position: floodplain

Slope: (0-5)

Aspect: variable

\section{SOIL CHARACTERISTICS}

Organic thickness: (0-15)

Humus form: no data

Surface texture: L,SiL

Effective texture: SiL,

Depth to Mottles/Gley: none

Drainage: well, mod. well

Parent material: F, GF

Soil subgroup:, O.R, O.HR

\section{ECOSITE PHASES}

dd1 sedge-bog sedge $(\mathrm{n}=6)$

$\mathrm{dd} 2$ shrubland( $\mathrm{n}=24)$ 


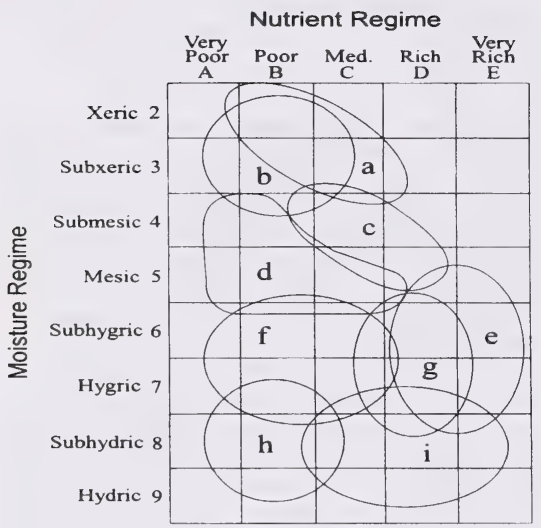

Moisture regime: mesic, subhygric

Nutrient regime: medium

Topographic position: level, midslope

Slope: (0-5)

Aspect: variable

\section{SOIL CHARACTERISTICS}

Organic thickness: $(0-15)$

Humus form: no data

Surface texture: SiL, L

Effective texture: SL, SiL, L

Depth to Mottles/Gley: none

Drainage: mod. well, well

Parent material: F

Soil subgroup:, O.R, O.HR

\section{COMMUNITY TYPES}

SACFA13 Sedge-Bog sedge-Tufted hairgrass $(n=6)$

\section{CHARACTERISTIC SPECIES}

\section{Shrubs}

[1] Shrubby cinquefoil

Forbs

[7] Alpine goldenrod

[3] Graceful cinquefoil

[1] Strawberry

[5] Yarrow

[6] Alpine bistort

\section{Graminoids}

[20] Bog sedge

[40] Sedge

[13] Tufted hairgrass

[7] Hairy wildrye

[3] Rocky mtn. fescue 


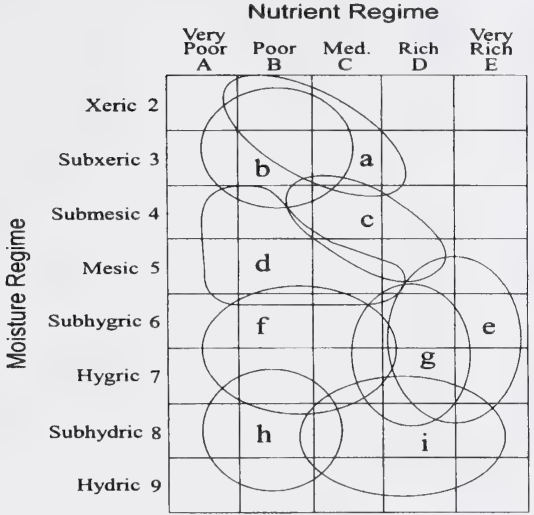

\section{CHARACTERISTIC SPECIES}

\section{Shrubs}

[7] Willow

[ 30 ] Bog birch

\section{Forbs}

[1] Alpine goldenrod

[2] Graceful cinquefoil

[3] Old man's whiskers

[1] Yarrow

[1] Alpine bistort

[2] False dandelion

[2] Tall larkspur

[1] Larkspur

\section{Graminoids}

[17] Bog sedge

[10] Sedge

[7] Rough fescue

[1] Hairy wildrye

[1] California oatgrass

\section{SITE CHARACTERISTICS}

Moisture regime: mesic, subhygric

Nutrient regime: medium

Topographic position: level, midslope

Slope: $(0-5)$

Aspect: variable

\section{SOIL CHARACTERISTICS}

Organic thickness: (0-15)

Humus form: no data

Surface texture: SiL, L

Effective texture: SL, SiL, L

Depth to Mottles/Gley: none

Drainage: mod. well, well

Parent material: $F$

Soil subgroup:, O.R, O.HR

\section{COMMUNITY TYPES}

SACFB8 Bog birch/Bog sedge-Sedge ( $\mathrm{n}=5)$

SACFB9 Bog birch-Willow/Rough fescue $(n=4)$

SACFB10 Bog birch/Rough fescue-Bog sedge $(n=1)$

SACMB4 Willow-Bog birch/Bog sedge $(n=14)$ 


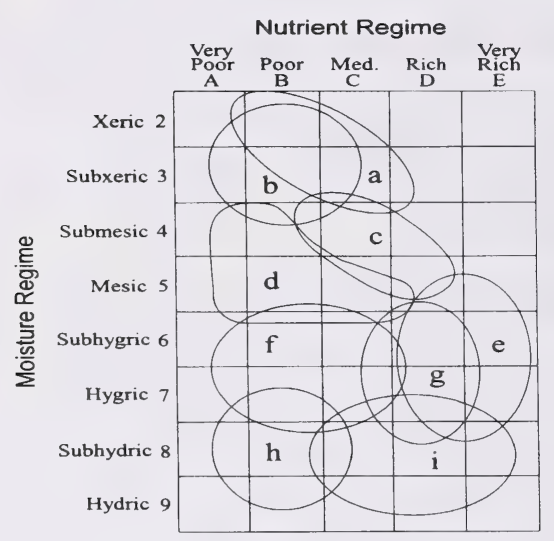

\section{CHARACTERISTIC SPECIES}

\section{Shrubs}

[2] Willow

[1] Bog birch

[1] Shrubby cinquefoil

\section{Forbs}

[3] Veiny meadow rue

[2] Graceful cinquefoil

[1] Old man's whiskers

[2] Yarrow

[1] Alpine bistort

[2] False dandelion

[2] Tall larkspur

\section{Graminoids}

[ 10] Tufted hairgrass

[10] Sedge

[2] Slender wheatgrass

[1] Hairy wildrye

[1] California oatgrass

\section{SITE CHARACTERISTICS}

Moisture regime: mesic, subhygric

Nutrient regime: rich, medium

Topographic position: level, midslope

Slope: $(0-5)$

Aspect: variable

\section{SOIL CHARACTERISTICS}

Organic thickness: (0-15)

Humus form: mor, moder

Surface texture: SiL, L

Effective texture: SiL, L, CL, C, SiCL, SCL, LS

Depth to Mottles/Gley: $(0-25)$

Drainage: mod. well, well, poor

Parent material: $\mathrm{F}$

Soil subgroup:, R.G, O.HG, O.HR, O.MB, CU.R

\section{COMMUNITY TYPES}

SACFA4 Tufted hairgrass-Sedge $(n=18)$

SACFA 17 Fireweed-Meadow rue/Sedge-Hairy wildrye $(n=1)$ 


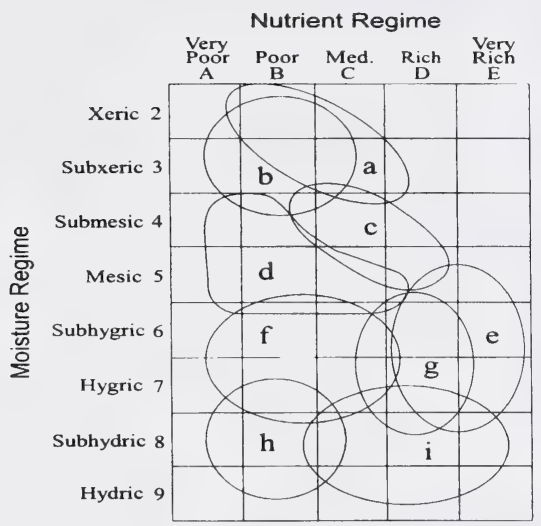

Moisture regime: mesic, subhygric

Nutrient regime: rich, medium

Topographic position: level, midslope

Slope: (0-5)

Aspect: variable

\section{SOIL CHARACTERISTICS}

Organic thickness: $(0-15)$

Humus form: mor, moder

Surface texture: SiL, L

Effective texture: SiL, L, CL, C, SiCL, SCL, LS

Depth to Mottles/Gley: $(0-25)$

Drainage: mod. well, well, poor

Parent material: $F$

Soil subgroup:, R.G, O.HG, O.HR, O.MB, CU.R

\section{COMMUNITY TYPES}

SACFA5 Sedge-Tufted hairgrass $(n=7)$

SACFA6 Sedge-Rocky Mtn. fescue-Alpine timothy $(n=6)$

SACFA7 Sedge-Slender wheatgrass-Fringed brome/Forb $(n=18)$

SACFA 15 Creeping red fescue-Sedge $(n=1)$

SACFA1 6 Kentucky bluegrass-Sedge/Dandelion( $n=1)$

\section{Shrubs}

[2] Willow

[1] Bog birch

[1] Shrubby cinquefoil

Forbs

[3] Veiny meadow rue

[2] Graceful cinquefoil

[1] Old man's whiskers

[2] Yarrow

[1] Alpine bistort

[2] False dandelion

[2] Tall larkspur

[3] Dandelion

\section{Graminoids}

[7] Tufted hairgrass

[10] Sedge

[2] Slender wheatgrass

[1] Hairy wildrye

[1] California oatgrass

[10 ] Creeping red fescue

[12] Kentucky bluegrass

[2] Rocky mtn. fescue 


\section{g2 willow $(\mathrm{n}=4)$}

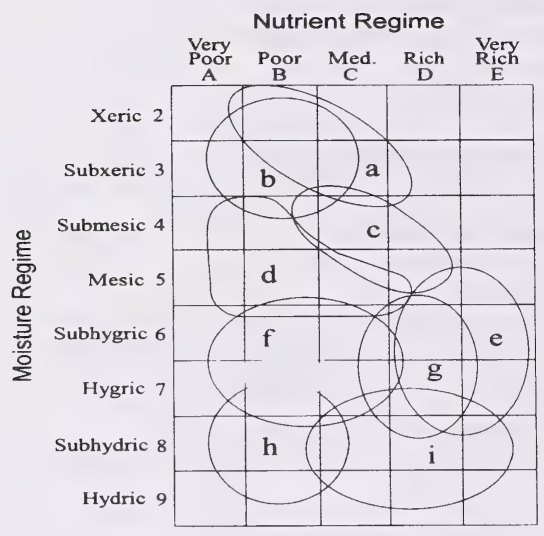

Moisture regime: hygric, subhygric Nutrient regime: rich, medium

Topographic position: level, midslope, toe Slope: (0-5)

Aspect: variable

\section{SOIL CHARACTERISTICS}

Organic thickness: (6-15)

Humus form: mor

Surface texture: humic, SiL, L,SiCL

Effective texture: humic, SiL, L, SCL, SC

Depth to Mottles/Gley: $(0-25)(26-50)$

Drainage: mod. well, poor, imperfect

Parent material: F, M, FL

Soil subgroup:, R.HG, O.R, T.H

\section{COMMUNITY TYPES}

SACFB2 Willow/Horsetail $(n=4)$

\section{CHARACTERISTIC SPECIES}

\section{Shrubs}

[30] Willow

[6] Bog birch

\section{Forbs}

[12] Variegated horsetail

[9] Common horsetail

[3] Showy everlasting

\section{Graminoids}

[6] Tufted hairgrass

[16] Sedge 


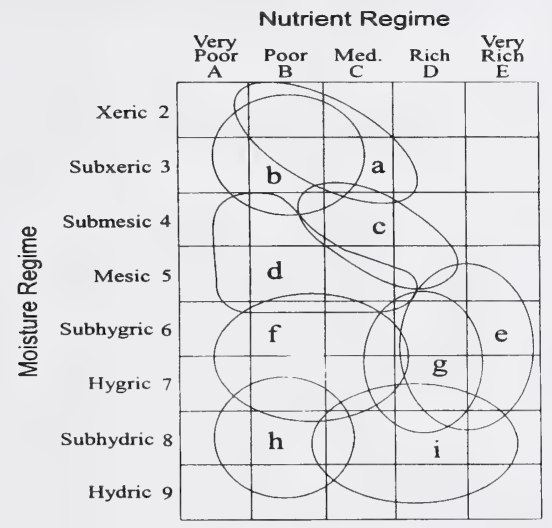

\section{CHARACTERISTIC SPECIES}

\section{Shrubs}

[2] Willow

[2] Bog birch

\section{Forbs}

[1] Elephant's head

[2] Common horsetail

[1] Woolly everlasting

[1] Lanced leaved paintbrush

\section{Graminoids}

[8] Tufted bulrush

[15] Sedge

[3] Cottongrass
Moisture regime: subhydric, hygric

Nutrient regime: medium, poor

Topographic position: depression

Slope: (0-5)

Aspect: variable

\section{SOIL CHARACTERISTICS}

Organic thickness: $(>80)$

Humus form: peatymor

Surface texture: fibric

Effective texture: mesic

Depth to Mottles/Gley: $(0-25)(26-50)$

Drainage: poor, imperfect

Parent material: $\mathrm{O}$

Soil subgroup:, T.M, FI.OC

\section{COMMUNITY TYPES}

SACFA2 Tufted bulrush $(\mathrm{n}=12)$

SACFA3 Sedge-Cottongrass $(n=7)$

\section{(Back to table of contents)}




\section{Results}

The analysis of the 785 plots distinguished 94 community types. These types were split into 4 categories:

\section{Subalpine}

Central and Northern Foothills
A. Native grasslands
17 community types
B. Native shrublands
11 community types

Central and Northern Rocky Mountains
A Native grasslands
9 community types
B. Native shrublands
8 community types

Southern Rocky Mountains
A. Native grasslands
19 community types
B. Native shrublands
5 community types
C. Grazed grasslands
9 community types
D. Deciduous
6 community types
E. Conifer
4 community types

\section{Alpine}
A. Native grasslands and shrulands 6 community types

The dominant plant species, canopy cover, environmental conditions, forage production and carrying capacity (when available) are outlined for each community type. 


\section{SUBALPINE SUBREGION}

\section{SUBALPINE SHRUB AND GRASSLAND ECOLOGY}

The Subalpine subregion has highly variable ecological conditions. Much of the variation is the result of complex topography, with a strong ecotonal effect from the surrounding subregions. For instance the grasslands and shrublands of the foothills west of Sundre, Rocky Mtn. House, Hinton and Grande Cache are very similar to the tufted hairgrass, California oatgrass, sedge and rough fescue dominated grass and shrublands of the Upper Foothills subregion. This area is represented by the Central and Northern Foothills, an area dominated by morainal and residuum deposits, gentler slopes (16-45\%) and Brunisolic and Luvisolic soils. The Central and Northern Foothills are transitional from the lower Upper Foothills subregion to the higher and steeper Central and Northern Rocky Mountains of the Subalpine subregion. The Central and Northern Rocky Mountains are typical of the morainal and talus deposits on steeper slopes (10-100\%), with Brunisolic and Regosolic soils in Banff and Jasper National Parks. These areas are transitional from the lower Subalpine to the higher Alpine subregion. Many species such as bog sedge, heather spp., white mountain avens which are characteristic of alpine communities start to become predominant in these areas. Grasslands on steep, south-facing slopes are dominated by hairy wildrye, junegrass and shrubby cinquefoil.

In southern Alberta (west of Turner valley, south of Blairmore) the subalpine grasslands and shrublands are strongly influenced by the lower Montane subregion. Many of the grass species associated with the Montane (rough fescue, Parry oatgrass, Idaho fescue) dominate the south facing slopes of the Subalpine. These grasslands are very different from the hairy wildrye dominated community types found in the Central and Northern Rocky Mountains. The Southern Rocky Mountains are dominated by residuum, morainal and talus deposits on gentle to steep slopes (16-100\%). 


\section{SUBALPINE SUBREGION}

CENTRAL AND NORTHERN FOOTHILLS

NATIVE GRASSLANDS AND SHRUBLANDS

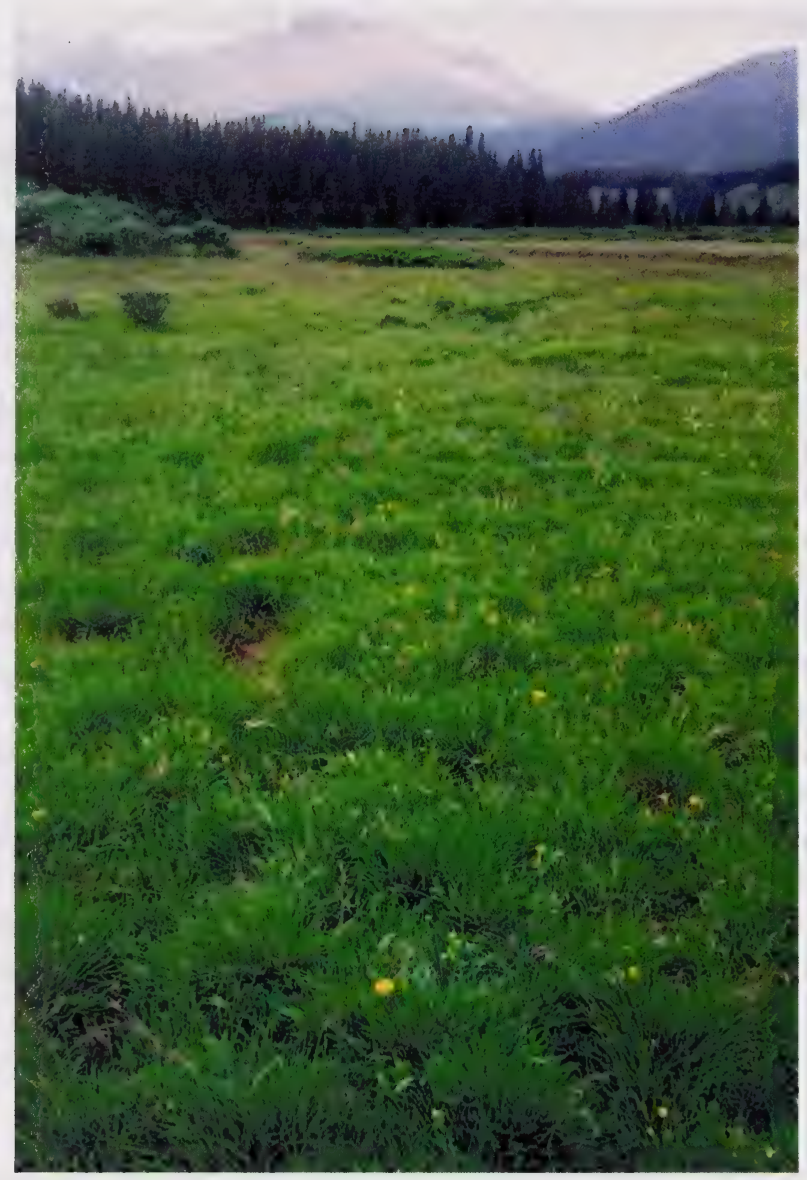

Figure 1. This figure is typical of the Tufted hairgrass-Sedge community with succession to a Willow-Bog birch dominated community type in the Central and Northern Foothills of the Subalpine subregion. 


\section{Native grass and shrubland ecology of the Foothills}

The native grass and shrubland community types in the Central and Northern Foothills of the Subalpine subregion (Table 2) are found in the valley bottoms adjacent to streams and rivers. The community types in this area are very similar to the grass and shrublands found in the Upper Foothills subregion and represent a transition from the lower Upper Foothills subregion to the Central and Northern Rocky Mountains of Banff and Jasper National Parks. The sequence of these community types along a moisture gradient from wet (Sedge meadows) to dry south facing slopes (Blunt sedge-Junegrass/Bearberry, Fringed sage/Junegrass-Sedge) is outlined in Figure 2. The change in species composition from the wet sedge meadows to tufted hairgrass, California oatgrass or rough fescue meadows may occur over a 3 foot elevational gradient. The presence of bog sedge (Kobresia myosuroides) in the White Mtn. avens-Bog sedge and Sedge-Bog sedgeTufted hairgrass community types appears to indicate the transition from the lower Central and Northern Foothills to the higher Central and Northern Rocky Mountains. Ogilvie (1969) and Corns and Achuff (1982), described bog sedge dominated community types in the higher elevations of the subalpine and alpine of the Rocky Mountains of Banff and Jasper National Parks.

The maintenance of these grassland community types is extremely fire dependent. The lack of fire quickly allows bog birch and willow to expand shading the modal grassland community types. Prolonged shading causes the understory composition to shift from a tufted hairgrass-California oatgrass dominated understory to a slender wheatgrass-hairy wildrye dominated understory (Figure 2). Under a heavy shrub cover there is little forb or grass cover. Increased shrub cover also causes a decline in forage productivity and reduces the accessiblility for livestock.

Many of these subalpine grass and shrublands are very fragile because of exposure and cold climate. The forage productivity is generally only half of what is found in the lower Upper Foothills subregion and recovery from overgrazing will likely take some time because of the poor growing conditions. As a result grazing by domestic livestock should be done with caution. 


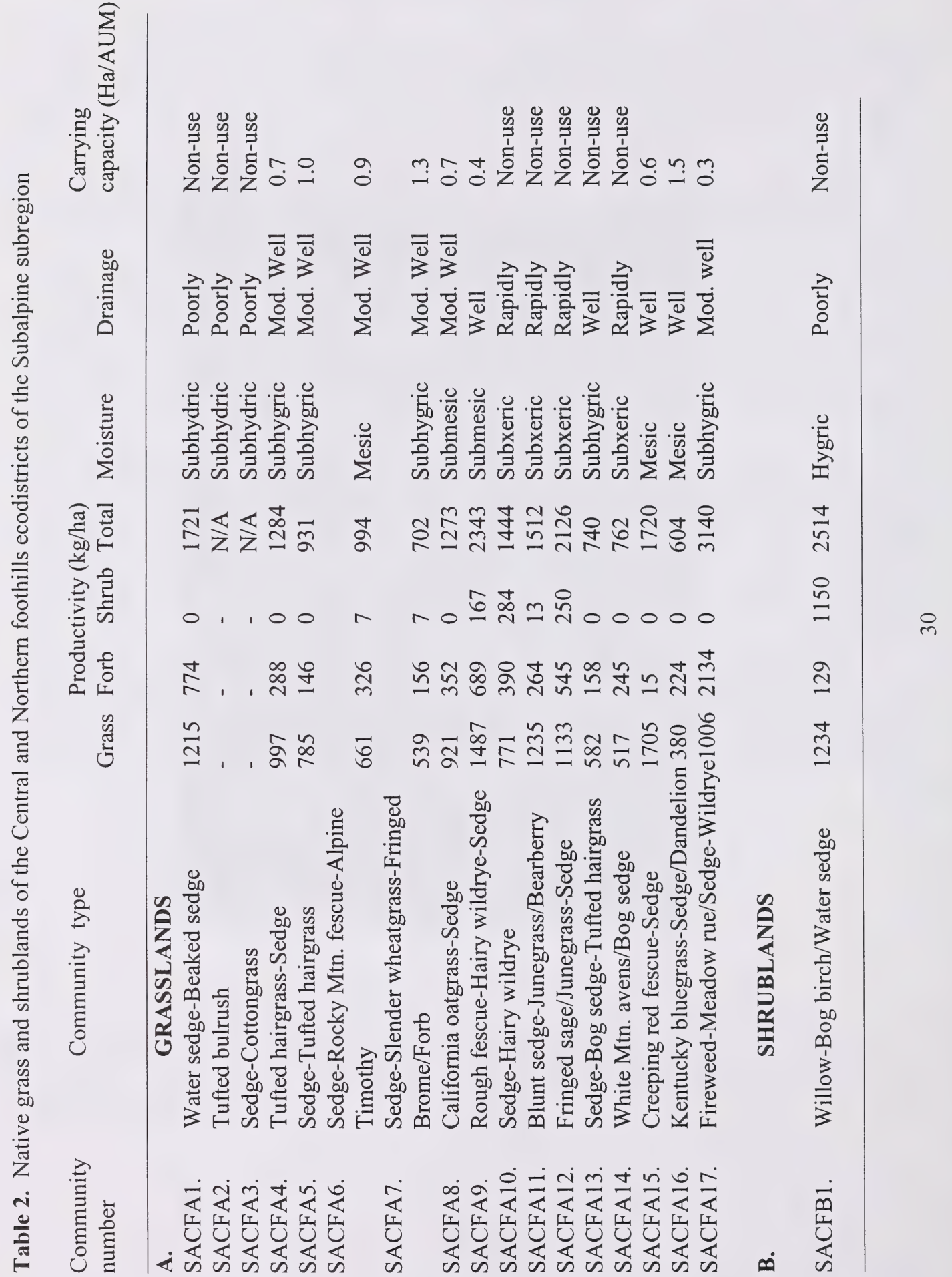




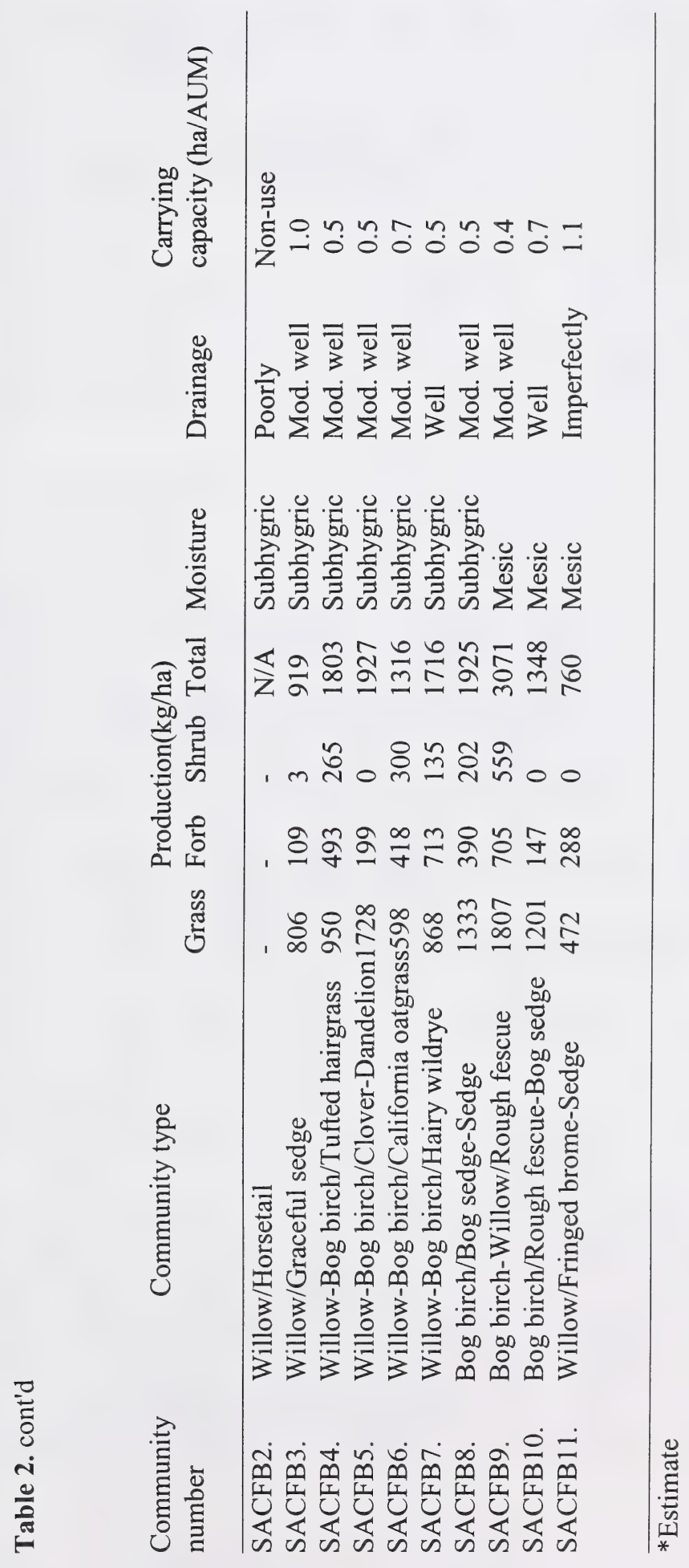




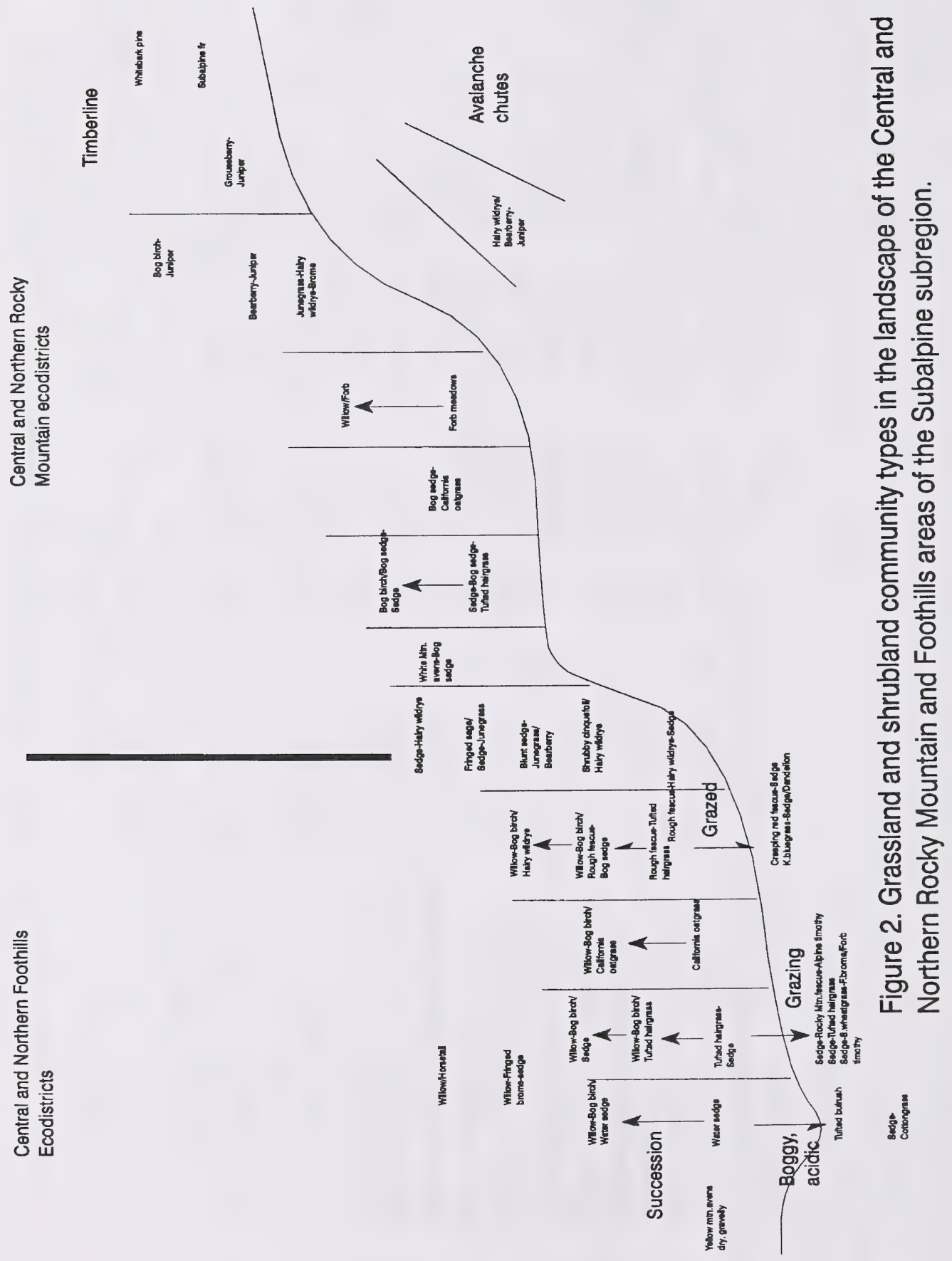




\section{Native grass and shrublands in Central and Northern Mountain and Foothills areas}

1. Community above timberline (Alpine subregion)..........Alpine section of guide

Community not above timberline, meadows, shrublands or south facing slopes dominated by shrubs and grass.

2. Moist sites, community dominated by shrubs $>20 \%$ cover (willow, bog birch) or timberline communities with dwarf trees or grouseberry see shrub key pg 34

Drier to moist sites shrub cover $<10 \%$ site dominated by grasses and forbs

3. Community very wet free standing water, dominated by sedge, cottongrass or tufted bulrush Community drier, dominated by tufted hairgrass, rough fescue, california oatgrass, hairy wildrye, juniper or bearberry.

4. Very wet nutrient rich sites dominated by water or beaked sedge. SACFA1 Very wet nutrient poor, acidic sites dominated by tufted bulrush and cottongrass.............

5. Site dominated by tufted bulrush..................................................SACFA2 Site dominated by cottongrass and sedge. SACFA3

6. Grasslands of meadows and lowland areas.... Grasslands of south facing slopes, or windswept ridges, hairy wildrye, bearberry, white mtn. avens dominated

7. Higher elevation sites near or at timberline, moist sites dominated by wandering daisy, globeflower, mountain marigold. .SACMA2

Lower elevation sites, valley bottoms adjacent to streams or rivers or if higher elevation dry sites dominated by bog sedge.

8. Disturbed or grazed community types dominated by Kentucky bluegrass, creeping red fescue, dandelion, alpine bluegrass, alpine timothy or fireweed. 9 Undisturbed community types dominated by rough fescue, California oatgrass, bog sedge, tufted hairgrass, and sedge species......

9. Moderately grazed site native increasers dominant (slender wheatgrass, sedge, fringed brome, rocky mtn. fescue, alpine timothy), Alpine or Kentucky bluegrass increasing in cover.

Heavily grazed sites dominated by Kentucky bluegrass or abandoned airstrips dominated by creeping red fescue or native

forb species (fireweed, veiny meadow rue).

12

10. Site dominated by Alpine bluegrass.

SACMA8

Site dominated by rocky mtn. fescue, alpine timothy, sedge, slender wheatgrass, fringed brome (moister sites)......

\section{SACFA6}

11. Site dominated by rocky $\mathrm{mtn}$. fescue, alpine timothy, sedge.

Site dominated by slender wheatgrass, sedge, fringed brome ...................SACFA7
Heavily grazed site dominated by Kentucky bluegrass and dandelion........SACFA16

12. Heavily grazed site dominated by Kentucky bluegrass and dandelion........SACFA16 Abandoned airstrips dominated by creeping red fescue, or invaded strips dominated by forbs (fireweed, veiny meadow)

13 Site dominated by creeping red fescue ................................................... 15 Moister disturbed site dominated by fireweed and veiny meadow rue...SACFA17

14. Moist sites dominated by sedge and tufted hairgrass.

Drier sites dominated by rough fescue, hairy wildrye, bog sedge, yellow dryas or California oatgrass.

5. Site dominated by tufted hairgrass, sedge co-dominant

16. Sites dominated by rough fescue and hairy wildrye

SACFA 9

Sites dominated by California oatgrass, bog sedge, or yellow dryas.

SACMA9

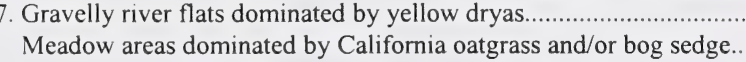

18. Site dominated by bog sedge and california oatgrass.

Site dominated by california oatgrass and sedge, bog sedge not present.........SACFA8

19. Site dominated by bog sedge, california oatgrass, drier sites..........................SACMA1 Site co-dominated by bog sedge, tufted hairgrass, and sedge moister sites... SACFA13

20. Lower elevation grasslands in the Foothills of the Subalpine.

Higher elevation grasslands in the mountains of the Subalpine.

21 Northern wheatgrass dominated site. 
Fringed sage, sedge and junegrass dominated slope.

SACFA12

22. Avalanche slopes dominated by hairy wildrye, juniper, and bearberry....SACMA6

Drier sites or windswept ridges dominated hairy wildrye, juniper, bearberry, shrubby cinquefoil, white mtn. avens. SACFA14

23. Windswept ridges dominated by white $\mathrm{mtn}$. avens.

South facing slopes dominated by hairy wildrye.

24. Shallow rocky soils with little grass cover, site dominated by bearberry.. SACMA4

Deeper soils, good grass cover dominated by hairy wildrye, junegrass.

SACMA3

25. Shrubby cinquefoil dominant in stand

Grass cover extensive, dominated by hairy wildrye, junegrass, and brome....SACMA5

\section{Shrub dominated communities}

1. Timberline communities dominated by whitebark pine, subalpine fir, grouseberry, or willow communities with marsh marigold, wandering daisy or globeflower in understory ........................................... 2

Riparian communities adjacent to streams or rivers............................................... $\quad 5$

2. Trees present in community (whitebark pine, subalpine fir) or grouseberry dominated.... 3 Moist seepage areas at treeline dominated by glooetlower, wandering daisy or marsh marigold in understory...

SACMB6

3. Trees (subalpine fir, whitebark pine) on site.

Grouseberry dominated shrubland.....

SACMB7

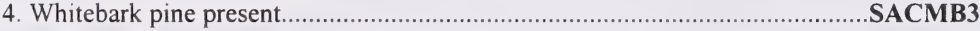

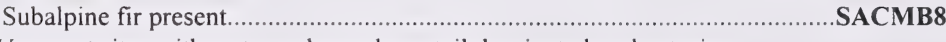

5. Very wet sites with water sedge or horsetail dominated understories.

Drier sites with tufted hairgrass, california oatgrass, bog sedge, hairy wildrye, rough fescue Kentucky bluegrass, dandelion dominated understories.

6. Water sedge dominated understory

SACFB1, SACMB1

Horsetail dominated understory.

SACFB2

7. Grazed communities dominated by clover and dandelion in understory.

SACFB5

Ungrazed sites dominated by native forbs and grasses in understory.

8. Shrubland communities on seepage areas on south facing slopes with shallow soils, dominated by bog birch and juniper.

SACMB5

Meadows and lowland shrublands dominated by rough fescue, bog sedge, california oatgrass, tufted hairgrass, hairy wildrye

or sedge in the understory......

9

10

11

Tufted hairgrass, california oatgrass, bog sedge, sedge, hairy wildrye dominate.

10. Rough fescue and bog sedge dominate understory higher elevations.

Rough fescue dominates, bog sedge not present lower elevations

SACFB 10

SACFB9

11. Moister sites with deep fluvial deposits dominated by tufted hairgrass, sedge, or fringed brome in understory.

Drier sites which are well drained at the surface dominated by hairy wildrye, sedge, bog sedge or california oatgrass in understory.

12. Tufted hairgrass or sedge dominated understory.

Fluvial areas with Fringed brome dominated understory, lower elevation.

13. Tufted hairgrass dominates understory

Graceful sedge and other sedge species dominate understory......

.SACFB3, SASMB2

14. Modal sites with hairy wildrye and sedge dominating understory. Sites dominated by california oatgrass or bog sedge in understory...

15. Hairy wildrye dominates understory...... Graceful sedge and other sedge species dominate understory

16. California oatgrass dominates understory...... Bog sedge dominates understory.
SACFB 11

SACFB4 


\section{SACFA1. Water sedge-Beaked sedge meadows}

(Carex aquatilis-Carex rostrata)

$\mathbf{n}=\mathbf{1 1}$ This community type is found in all ecodistricts of the subalpine. Wet conditions and periodic flooding result in the formation of water sedge-beaked sedge meadows. Bog birch and willow will invade into the drier edges of these meadows to form the Willow-bog birch/Water sedge community type.

These community types are quite productive producing nearly $2000 \mathrm{~kg} / \mathrm{ha}$ of forage, but the high water table in the spring and summer when these meadows are most palatable limits livestock use. A study in the Yukon found that crude protein on these meadows declined from a high of $10 \%$ in May to less than $5 \%$ in September (Bailey et al. 1992). As a result, these meadows would be rated as secondary or non-use range.

\section{PLANT COMPOSITION CANOPY COVER(\%) \\ MeAN RANGe CONST.}

\section{SHRUBS}

SMOOTH WILLOW

(Salix glauca)

BOG BIRCH

(Betula glandulosa)

\section{FORBS}

ARROW LEAVED COLTSFOOT

(Petasites sagitatus) 7

\section{GRASSES}

WATER SEDGE

(Carex aquatilis)

BEAKED SEDGE

(Carex rostrata)

ROCKY-GROUND SEDGE

(Carex saxatilis)

TUFTED HAIRGRASS

(Deschampsia cespitosa)

$1 \quad 0-7 \quad 27$

3

$0-20$

46

$0-14 \quad 18$

23

$0-62$

64

$11 \quad 0-42 \quad 55$

$9 \quad 0-70 \quad 18$

$0-5 \quad 64$

\section{ENVIRONMENTAL VARIABLES}

MoIsture Regime:

HYGRIC

\section{NUTRIENT REGIME \\ PERMESOTROPHIC}

ElEVATION:

$1750 \mathrm{M}$

SOIL DRAINAGE:

POORLY

\section{Forage Production IN KG/HA}

\author{
GRASS 1215 \\ FORBS 774 \\ Total $1721 *$ Estimate
}

SugGested GRAZING CAPACITY NON-USE 


\section{SACFA2. Tufted bulrush \\ (Scirpus cespitosus)}

$\mathrm{n}=12$ This community type occurs on subhydric to hydric, lower subalpine sites (1490-1870 m) on nearly level slopes. Corns and Achuff (1982), described this community type on poorly drained soils in the valleys of Banff and Jasper National Park. The soils are dominated by Terric Mesisols and Orthic Gleysols. They felt this community type was successionally mature.

This community type and the Water sedge-Beaked sedge both occupy poorly drained sites with free standing water, but the dominance of tufted bulrush appears to indicate acidic boggy and peaty sites (Scoggan 1978).

\section{Plant CoMposition Canopy Cover(\%)}

Mean Range Const.

\section{SHRUBS}

SHRUBBY CINQUEFOIL

$\begin{array}{llll}\text { (Potentilla fruticosa) } & 6 & 0-35 & 75\end{array}$

BOG BIRCH

(Betula glandulosa) $3 \quad 0-10 \quad 50$

FORBS

ELEPHANT'S HEAD

(Pedicularis groenlandicum) $1 \quad 0-5 \quad 58$

WOOLY EVERLASTING

(Antennaria lanata)

GRASSES

TUFTED BULRUSH

(Scirpus cespitosus)

WATER SEDGE

(Carex aquatilis)

RUSH-LIKE SEDGE

(Carex scirpoidea)
$61 \quad 18-85 \quad 100$

$2 \quad 0-10 \quad 42$

$1 \quad 0-10 \quad 17$
ENVIRONMENTAL VARIABLES

MOISTURE REGIME:

HYGRIC-SUBHYGRIC

NUTRIENT REGIME:

PERMESOTROPHIC

ELEVATION:

1678(1490-1870) M

SOIL DRAINAGE:

POORLY

Forage Production Kg/Ha

NOT AVAILABLE

SugGested GRAZING CAPACITY

NON-USE 


\section{SACFA3. Sedge-Cottongrass \\ (Carex spp.-Eriophorum spp.)}

n=7 Corns and Achuff (1982), described a cottongrass dominated community on hydric sites in the Upper subalpine on level to gentle slopes. They found the cottongrass communities to form on depressional areas where the snow melts late and seepage is recieved throughout the growing season. Cottongrass is also characteristic of muskegs and boggy marshes. It appears that this community is located on better drained areas adjacent to tufted bulrush dominated community type. The high acidity of the soil appears to favour the growth of cottongrass, rushlike sedge and rocky ground sedge over water sedge.

\section{Plant Composition Canopy Cover(\%)} Mean Range Const.

\section{SHRUBS}

WILLOW SPP.

(Salix spp.)

BOG BIRCH

(Betula glandulosa)

$$
4
$$$$
1-11
$$

100

\section{FORBS}

LANCED -LEAVED PAINT BRUSH

(Castilleja occidentalis) 2

WOOLLY EVERLASTING

(Antennaria lanata)

COMMON HORSETAIL

(Equisetum arvense)

1

3

GRASSES

RUSH-LIKE SEDGE

(Carex scirpoidea)

ROCKY-GROUND SEDGE

(Carex saxatilis)

$12 \quad 0-80$

0-25

57

SHORT SEDGE

(Carex curta)

$7-0-50$

14

SHEATHED COTTONGRASS

(Eriophorum vaginatum) 1

TALL COTTONGRASS

(Eriophorum polystachion)5

$0-10 \quad 14$

$0-18 \quad 57$

\section{ENVIRONMENTAL VARIABLES}

\section{MOISTURE REGIME:}

HYDRIC-SUBHYGRIC

NUTRIENT REGIME:

EUTROPHIC

ELEVATION:

$1586 \mathrm{M}$

SOIL DRAINAGE:

POORLY

\section{Forage Prodcution Kg/Ha}

Not AVAILABLE

SUGGESTED GRAZING CAPACITY

NON-USE 


\section{SACFA4. Tufted hairgrass-Sedge \\ (Deschampsia cespitosa-Carex spp.)}

$\mathbf{n}=18$ This community type is located on moist sites that are better drained and slightly drier than the pure sedge meadows. Willoughby(2001), found that tufted hairgrass is a common plant species on lowland sites in the valley bottoms of the Upper Foothills subregion. Willoughby (1992), found when this community type is protected from grazing for 25-30 years, willow and bog birch expand and tufted hairgrass and sedge decline. The decline in graminoid cover also results in a decline in available forage production. Continuous heavy grazing causes hairgrass to decline and the site will be invaded by Kentucky bluegrass and dandelion.

Bork (1994), found this community type to be the most productive type described in Willmore Wilderness park. Forage production averages over $2000 \mathrm{~kg} / \mathrm{ha}$ and can vary from $(800-3300 \mathrm{~kg} / \mathrm{ha})$. It is interesting to note that forage production on this community type declines from an average of $2200 \mathrm{~kg} / \mathrm{ha}$ in the Upper Foothills to $1555 \mathrm{~kg} / \mathrm{ha}$ in the Subalpine subregion. The shorter growing season and colder climate may account for this change in forage productivity. These community types when located next to backcountry campsites will be utilized by horses.

\section{Plant Composition Canopy Cover(\%)} MEAN RANGE CONST.

\section{SHRUBS}

BARCLAY'S WILLOW

(Salix barclayi)

$2 \quad 0-7 \quad 22$

\section{FORBS}

SLENDER BLUE BEARDSTONGUE

(Penstemon procerus) $\quad 2 \quad 0-9 \quad 72$

VEINY MEADOW RUE

(Thalictrum venulosum) $5 \quad 0-14 \quad 50$

YARROW
(Achillea millefolium) 4

(Potentilla diversifolia) 12

OLD MAN'S WHISKERS

(Geum triflorum)

ALPINE GOLDENROD

(Solidago multiradiata)

$0-14 \quad 94$

$0-43 \quad 72$

$0-6 \quad 22$

$0-13 \quad 72$

\section{GRASSES}

\section{GRACEFUL SEDGE}

TUFTED HAIRGRASS

(Deschampsia cespitosa) $31 \quad 12-57 \quad 100$

SLENDER WHEATGRASS

(Agropyron trachycaulum) 2

SHEEP FESCUE

(Festuca saximontana) $3 \quad 0-16 \quad 33$

HAIRY WILDRYE

(Elymus innovatus)

$3 \quad 0-20 \quad 50$

\section{ENVIRONMENTAL VARIABLES}

MOISTURE REGIME:

MESIC TO HYGRIC

NUTRIENT REGIME:

MESOTROPHIC TO PERMESOTROPHIC

ELEVATION:

1896(1630-2130) M

SOIL DRAINAGE:

MOD. WELL TO VERY POORLY

SLOPE:

$$
3(1-5) \%
$$

ASPECT:

VARIABLE

Forage Production Kg/Ha

GRASS $997(532-1923)$

FORBS 288(0-928)

TOTAL $1284(532-2118)$

\section{SUGGESTED GRAZING CAPACITY}

$0.7 \mathrm{HA} / \mathrm{AUM}$ 


\section{SACFA5. Sedge-Tufted hairgrass \\ (Carex spp.-Deschampsia cespitosa)}

$\mathbf{n}=\mathbf{8} \quad$ This community type was described in the Job Lake, Blackstone-Wapiabi Forest Land Use Zones. These areas are extensively utilized by equestrian backcountry users. This community type appears to develop from moderate to heavy grazing pressure on a Tufted hairgrass-Sedge community. Continued heavy grazing pressure appears to cause a further decline in tufted hairgrass to form the Sedge-Rocky Mtn. fescue-Alpine timothy and Sedge-Slender wheatgrass-Fringed brome/Forb community types. If the seed source becomes available these sites have the potential to be invaded by Kentucky bluegrass, timothy, clover and dandelion if the grazing pressure continues.

\section{Plant Composition Canopy Cover(\%) \\ Mean Range Const.}

\section{SHRUBS}

BOG BIRCH

$\begin{array}{llll}\text { (Betula glandulosa) } & 1 & 0-2 & 13\end{array}$

\section{FORBS}

ALPINE BISTORT

(Polygonum viviparum) 1

VEINY MEADOW RUE

(Thalictrum venulosum) 4

YARROW

(Achillea millefolium) 7

SMOOTH LEAVED CINQUEFOIL

(Potentilla diversifolia) 9

PURPLE AVENS

(Geum rivale)

GREEN SORREL

(Rumex acetosa)

Grasses

GRACEFUL SEDGE

(Carex praegracilis)

TUFTED HAIRGRASS

(Deschampsia cespitosa) 18

KENTUCKY BLUEGRASS

(Poa pratensis)

ALPINE FESCUE

(Festuca brachyphylla) 3

CALIFORNIA OATGRASS

(Danthonia californica)

$0-18 \quad 75$

$0-42 \quad 63$

$0-8 \quad 75$

$19-98 \quad 100$

$3-34 \quad 100$

$0-15 \quad 75$

$0-15 \quad 63$

$0-9 \quad 50$

\section{ENVIRONMENTAL VARIABLES}

MOISTURE REGIME:

MESIC -SUBHYGRIC

NUTRIENT REGIME:

MESOTROPHIC TO PERMESOTROPHIC

ELEVATION:

1866(1832-1895) M

SOIL DRAINAGE:

WELL TO MOD. WELL

\section{Forage Production KG/HA}

$$
\begin{array}{ll}
\text { GRASS } & 785(341-1369) \\
\text { FORBS } & 146(0-443) \\
\text { TOTAL } & 931(412-1738)
\end{array}
$$
$1.0 \mathrm{HA} / \mathrm{AUM}$

\section{SUGGESTED GRAZING CAPACITY}




\section{SACFA6. Sedge-Rocky Mountain fescue-Alpine timothy (Carex praegracilis-Festuca saximontana-Phleum alpina)}

$\mathbf{n}=\mathbf{6}$ This community type appears to arise from grazing of a modal Tufted hairgrass-Sedge community type. The six sites described in this community were all located next to outfitter campsites and had been heavily grazed by horses. The heavy grazing pressure causes tufted hairgrass to decline and allows non-native plants such as Kentucky bluegrass and dandelion to invade onto the site. The heavy grazing pressure also appears to change the moisture regime of the site. Many of the plant species on the site, Rocky mountain fescue, Alpine timothy, Alpine bluegrass, junegrass and hairy wildrye are better adapted to well drained, drier conditions. Perhaps, the removal of litter causes the water to drain away from the site more rapidly. Bork (1994), noticed this on similar sites in Willmore Wilderness park. This community type maybe grazed heavier than the previously described Sedge-Tufted hairgrass community type or it could be drier and the grazing pressure shifts the community to one dominated by more drought resistant $\mathrm{sp}^{\cdots}$ :

\section{Plant Composition Canopy Cover(\%)} MEAN RANGe CONST.

\section{SHRUB}

BOG BIRCH

(Betula glandulosa) $\quad 3 \quad 0-12 \quad 33$

\section{FORBS}

SLENDER BLUE BeARdTONGUE

\section{(Penstemon procerus) 2}

YARROW

(Achillea millefolium) 6

GRACEFUL CINQUEFOIL

(Potentilla gracilis) 4

CHICKWEED

(Cerastium arvense)

DANDELION

(Taraxacum offincinale) 2

NORTHERN VALERIAN

(Valeriana dioica)

$2 \quad 0-5 \quad 50$

\section{GRASSES}

ROCKY MOUNTAIN FESCUE

(Festuca saximontana) 15

TUFTED HAIRGRASS

(Deschampsia cespitosa) 4

KENTUCKY BLUEGRASS

(Poa pratensis)

GRACEFUL SEDGE

(Carex praegracilis)

ALPINE TIMOTHY

(Phleum commutatum)

\section{ENVIRONMENTAL VARIABLES}

MOISTURE REGIME:

SUBMESIC-SUBHYGRIC

NUTRIENT REGIME:

SUBMESOTROPHIC TO MESOTROPHIC

ELEVATION:

1886(1634-2130) M

SOIL DRAINAGE:

WELL TO IMPERFECTLY

SLOPE: $6(2-10) \%$

ASPECT: VARIABLE

\section{Forage Production Kg/HA}

GRASS $661(294-1121)$

FORB $326(0-524)$

SHRUB $7(0-14)$

TOTAL $994(729-1341)$

\section{SUGGESTED GRAZING CAPACITY}

$0.9 \mathrm{HA} / \mathrm{AUM}$ 


\section{SACFA7. Sedge-Slender wheatgrass-Fringed brome/Forbs \\ (Carex praegracilis-Agropyron trachycaulum-Bromus ciliatus/Forbs)}

$\mathbf{n}=\mathbf{1 8}$ This community type appears to arise from grazing of a modal Tufted hairgrass-Sedge community type. All the sites described in this community were found adjacent to outfitter campsites in the Job Lake, BlackstoneWapiabi forest land use zones. The heavy grazing pressure causes tufted hairgrass to decline and allows sedges, slender whatgrass and fringed brome to increase. This community type maybe slightly moister than the previously described Sedge-Rocky mountain fescue-Alpine timothy community. As a result there is succession to more mesic loving plants rather than the drought tolerant plants described in the previous community type.

\section{Plant COMPOSITION CANOPY COVER(\%) Mean Range CONST.}

\section{SHRUBS}

WILLOW SPP. (Salix spp.)

FORBS

ALPINE BISTORT

(Polygonum viviparum) $7 \quad 0-59 \quad 67$

YARROW

(Achillea millefolium) 4

SMOOTH LEAVED CINQUEFOIL

(Potentilla diversifolia) 11

ALPINE GOLDENROD

(Solidago multiradiata) 4

STRAWBERRY

(Fragaria virginiana) 6

FALSE-DANDELION

(Agoseris glauca)

3

\section{GRASSES}

SLENDER WHEATGRASS

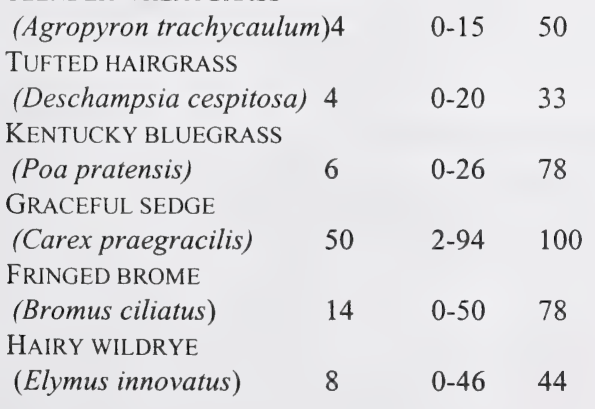

\section{ENVIRONMENTAL VARIABLES}

MOISTURE REGIME:

MESIC-HYGRIC

NUTRIENT REGIME:

MESOTROPHIC-PERMESOTROPHIC

ELEVATION:

1926(1830-2076) M

SOIL DRAINAGE:

WELL TO MODERATELY WELL

\section{Forage Production KG/HA}

\author{
GRASS 539(162-944) \\ FORB 156(0-370) \\ SHRUB $7(0-44)$ \\ TOTAL 702(354-1094)
}

\section{SUGGESTED GRAZING CAPACITY $1.3 \mathrm{HA} / \mathrm{AUM}$ OR 2.8 ACRES/AUM}




\section{SACFA8. California oatgrass-Sedge \\ (Danthonia californica-Carex spp.)}

$\mathbf{n}=\mathbf{5}$ This community is very similar to a community type described by Willoughby $(2001)$ in the Upper Foothills subregion. Corns and Achuff (1982), described a Willow/California oatgrass dominated community type in Banff and Jasper National Park. It appears dry, gravelly or stony soils, with a fluctuating water table support this moderately productive grassland. Small pockets of this community type occur throughout the Subalpine subregion. In the Yukon these small meadows were found to form in depressions which appeared to act as pronounced frost pockets (Bailey et al. 1992). The cold air drainage and poor nutrient quality of the soil limits the forage productivity of these sites.

\section{Plant COMPOSITION CANOPY COVER(\%)} Mean Range Const.

\section{SHRUBS}

WILLOW SPP.

(Salix spp.)

$3.8 \quad 0-13 \quad 60$

SHRUBBY CINQUEFOIL

(Potentilla fruticosa)

$0-10 \quad 60$

\section{FORBS}

TALL LARKSPUR

(Delphinium glaucum) 4
WILD STRAWBERRY

(Fragaria virginiana) 6

SMOOTH LEAVED CINQUEFOIL

(Potentilla diversifolia) 11

YARROW

(Achillea millefolium) 4

VEINY MEADOW RUE

(Thalictrum venulosum) 10

SLENDER BLUE BEARDTONGUE

(Penstemon procerus) 9

GRASSES

CALIFORNIA OATGRASS

$\begin{array}{llll}\text { (Danthonia californica) } & 37 & 15-60 & 100\end{array}$

GRACEFUL SEDGE

(Carex praegracilis) $\quad 24 \quad 0-63 \quad 40$

SLENDER WHEATGRASS

(Agropyron trachycaulum) $3 \quad 0-15 \quad 20$

HAIRY WILDRYE

(Elymus innovatus) $\quad 11 \quad 0-29 \quad 60$

SPIKED TRISETUM

(Trisetum spicatum) $\quad 1 \quad 0-5 \quad 60$

BOG SEDGE

(Kobresia myosuroides) $4 \quad 0-19 \quad 20$

\section{ENVIRONMENTAL VARIABLES}

MOISTURE REGIME:

SUBMESIC

NUTRIENT REGIME:

MESOTROPHIC

ELEVATION:

$1830(1380-2100) \mathrm{M}$

SOIL DRAINAGE:

MODERATELY WELL TO WELL

Forage Production KG/HA

GRASS 921

FORBS 352

TOTAL $1273 *$ EsTIMATE

\section{SUGGESTED GRAZING CAPACITY}

$0.7 \mathrm{HA} / \mathrm{AUM}$ OR 1.6 ACRES/AUM 


\section{SACFA9. Rough fescue-Hairy wildrye-Sedge \\ (Festuca scabrella-Elymus innovatus-Carex spp.)}

$\mathbf{n = 1 3}$ This community was described in the Panther Corners Forest Land Use Zone and in Willmore Wilderness Park on level to undulating ridges, terraces and lower slope positions with Orthic Eutric Brunisolic soils. It is very similar to the Rough fescue-Hairy wildrye community described by Willoughby(2001) in the Upper Foothills subregion and the Rough fescue-Wheatgrass-Hairy wildrye community described by Morgantini and Russell (1983) on Ribbon flats just north of the Panther Corners. This community type is moderately productive and one of the most important communities for wintering elk (Morgantini and Russell 1983). An examination of winter elk diets found that rough fescue made up 45 to $60 \%$ of their food intake during the months of December, January and March (Morgantini and Russell 1983). Care must be taken that this community type is not over-utilized by horses and that sufficient forage is left for overwintering elk.

Plant COMPOSITION CANOPY COVER (\%)

MEAN RANGE CONST.

SHRUBS

SHRUBBY CINQUEFOIL

(Potentilla fruticosa)

$\begin{array}{lll}8 & 0-31 \quad 92\end{array}$

FORBS

TALL LARKSPUR

(Delphinium glaucum)

WILD STRAWBERRY

(Fragaria virginiana)

GRACEFUL CINQUEFOIL

(Potentilla gracilis)

YARROW

(Achillea millefolium)

OLD MAN'S WHISKERS

(Geum triflorum)

AMERICAN VETCH

(Vicia americana)

\section{GRASSES}

ROUGH FESCUE

(Festuca scabrella)

SEDGE

(Carex spp.)

SLENDER WHEATGRASS

(Agropyron trachycaulum) 3
HAIRY WILDRYE

$\begin{array}{llll}\text { (Elymus innovatus) } & 6 & 1-18 \quad 100\end{array}$

JUNEGRASS

(Koeleria macrantha) $\quad 1 \quad 0-4 \quad 85$
MOISTURE REGIME:

SUBXERIC TO MESIC

NUTRIENT REGIME:

MESOTROPHIC -PERMESOTROPHIC

ELEVATION:

$1786(1600-2150) \mathrm{M}$

SOIL DRAINAGE:

WELL TO RAPIDLY

SLOPE:

$$
32(10-60) \%
$$

ASPECT:

SOUTHERLY

\section{Forage Production Kg/Ha}

ENVIRONMENTAL VARIABLES 


\section{SACFA10. Sedge-Hairy wildrye \\ (Carex spp.-Elymus innovatus)}

$\mathbf{n}=13$ This community was described in the Panther Corners Forest Land Use Zone on steep west and south facing slopes at higher elevations. It occupies sites that are similar to the Fringed sage/Sedge-Junegrass community, but this community type is found at elevations averaging over 2000 meters. This community type is similar to the hairy wildrye dominated communities described by Corns and Achuff (1982) at higher elevations in the subalpine of the Central Mountains ecodistrict (SACMA,4,5,6). This community type was only lightly utilized by elk. In contrast the lower elevation Fringed sage/Sedge-Junegrass exhibited signs of heavy elk use. The higher elevation of this community may limit access to wildlife in this area. It is possible that if this community type was heavily grazed it may resemble the Fringed sage/Sedge-Junegrass community described at lower elevations.

Plant Composition Canopy Cover(\%) MEAN RANGE CONST.

SHRUBS

SHRUBBY CINQUEFOIL

(Potentilla fruticosa)

$4 \quad 0-14 \quad 77$

FORBS

TALL LARKSPUR

(Delphinium glaucum) $1 \quad 0-5 \quad 54$

WILD STRAWBERRY

(Fragaria virginiana)

GRACEFUL CINQUEFOIL

(Potentilla gracilis)

YARROW

(Achillea millefolium)

OLD MAN'S WHISKERS

(Geum triflorum)

AMERICAN VETCH

(Vicia americana)

BEARBERRY

(Arctostaphylos uva-ursi)

GRASSES

ROUGH FESCUE

(Festuca scabrella)

2

SEDGE

(Carex spp.)

POA

(Poa spp.)

HAIRY WILDRYE

(Elymus innovatus)

JUNEGRASS

(Koeleria macrantha)

SMOOTH BROME

(Bromus inermis)

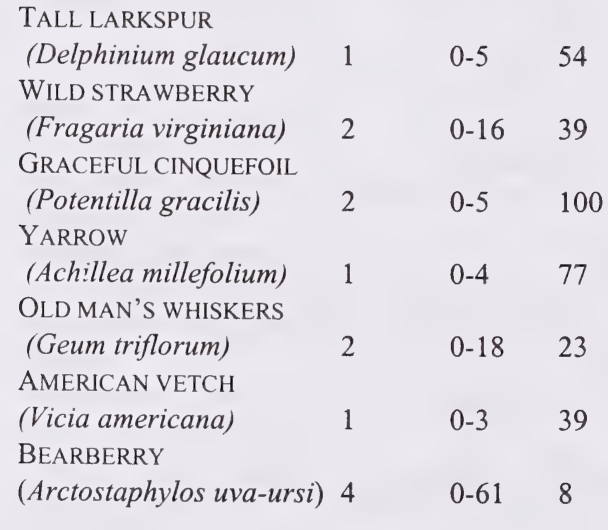

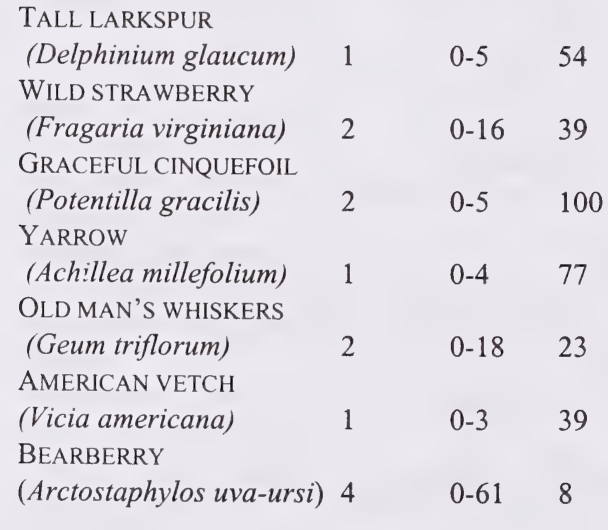

$0-16 \quad 39$

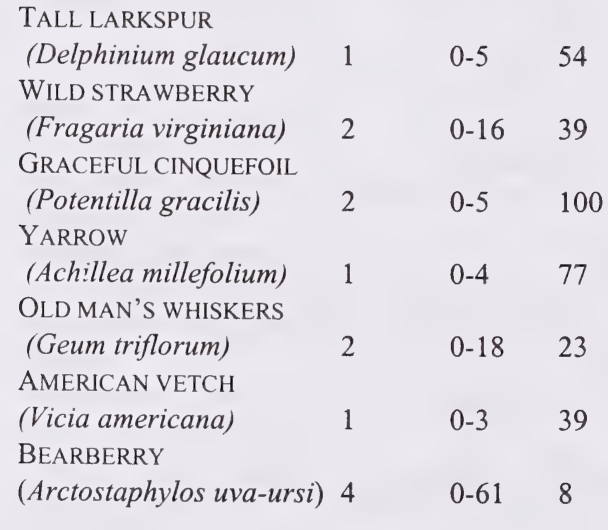

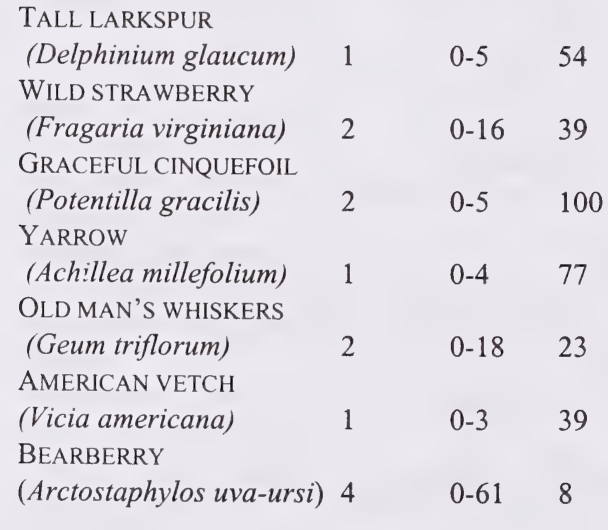

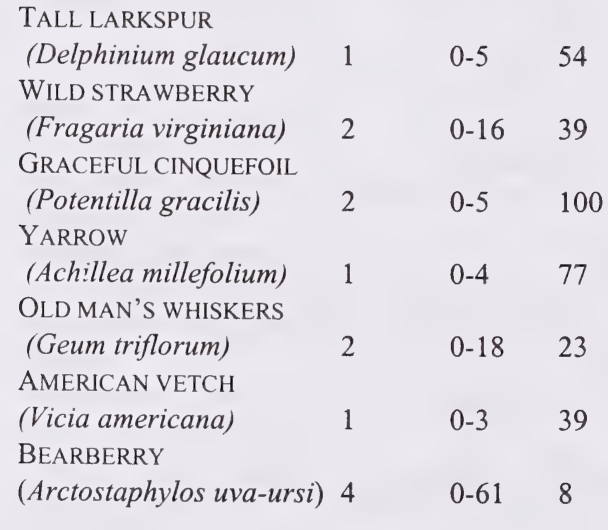

$1 \quad 0-3 \quad 39$

$0-61 \quad 8$

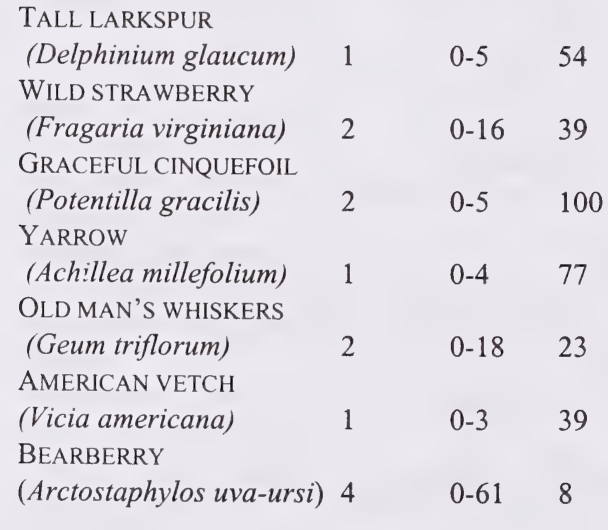

\section{ENVIRONMENTAL VARIABLES}

MOISTURE REGIME:

XERIC TO MESIC

NUTRIENT REGIME:

SUBMESOTROPHIC

ELEVATION:

2029(1650-2300)M

SOIL DRAINAGE:

WELL TO RAPIDLY

ASPECT:

SOUTHERLY AND WESTERLY

SLOPE:

$36(0-50) \%$

Forage Production KG/Ha

GRASS $771(460-1168)$

FORBS $390(160-1010)$

SHRUB $284(0-1712)$

TOTAL $1444(676-3150)$

\section{Suggested GRAZING CAPACITY}

NON-USE 


\section{SACFA11. Blunt sedge-Junegrass/Bearberry \\ (Carex obtusata-Koeleria macrantha/Arctostaphylos uva-ursi)}

$\mathbf{n}=\mathbf{3}$ This community type occurs on steep south facing slopes, with shallow soils, overlying sandstone bedrock. The majority of the vegetation are composed of drought tolerant species bearberry and junegrass. The inaccessibility and fragile nature of the soils make this community type unsuitable for grazing. This community is very similar to the Junegrass/Sage community described by Willoughby(2001) in the Upper Foothills subregion and the Low northern Sedge/Bearberry community described by Lane et al. (2000) in the Lower Foothills subregion on the south facing slopes of the Athabasca River valley.

Plant Composition Canopy Cover(\%)

\section{SHRUBS}

MEAN RANGe CONST.

\section{SHRUBBY CINQUEFOIL}

(Potentilla fruticosa)

$$
3
$$

100

\section{FORBS}

\section{BEARBERRY}

(Arctostaphylos uva-ursi) 11

SHOWY LOCOWEED

(Oxytropis splendens) 10

SWEET FLOWERED ANDROSACE

(Androsace chamaejasme) 7

ALPINE GOLDENROD

(Solidago multiradiata) 1

COMMON YARROW

(Achillea millefolium)

7

GRASSES

JUNEGRASS

(Koeleria macrantha) 10

SHEEP FESCUE

(Festuca saximontana)

BLUNT SEDGE

(Carex obtusata)

HAIRY WILDRYE

(Elymus innovatus)

SLENDER WHEATGRASS

(Agropyron trachycaulum) 3
0-16

67

9-10 $\quad 100$

$0-19 \quad 67$

$0-2 \quad 67$

$2-13 \quad 100$

$1-23$

100

$0-12 \quad 67$

$1-7 \quad 100$

$0-6 \quad 67$

$1-5 \quad 100$

\section{ENVIRONMENTAL VARIABLES}

MOISTURE REGIME:

XERIC TO SUBXERIC

NUTRIENT REGIME:

MESOTROPHIC

ELEVATION:

1990(1950-2070)M

SOIL DRAINAGE: RAPIDLY

SLOPE: $40(30-60) \%$

ASPECT: SOUTHERLY

\section{Forage Production KG/HA}

GRASS 1235(1196-1274)

FORB 264(148-380)

SHRUB 13(0-26)

TOTAL 1512(1370-1654)

SugGESTED GRAZING CAPACITY NON-USE 


\section{SACFA12. Fringed sage/White scaled sedge-Junegrass (Artemisia frigida/Carex xerantica-Koeleria macrantha)}

$\mathbf{n}=\mathbf{5}$ This community type occurs on steep south facing slopes, with shallow soils. It is very similar to the previously described Sedge-Junegrass/Bearberry community type, but lacks the cover of bearberry. The lack of bearberry cover in this community type may indicate that the soils of this type are better developed and slightly moister. The inaccessibility and fragile nature of the soils make this community type unsuitable for domestic livestock grazing. This community type is important winter habitat for migrating elk. The steepness of the slope and the southerly aspect limit snow accumulation and allows access to the forage supply. This community is very similar to the Junegrass/Sage community described by Willoughby(2001) in the Upper Foothills subregion.

\section{Plant CoMPOSITION CANOPY COVER(\%) MEAN Range CONST.}

SHRUBS

SHRUBBY CINQUEFOIL

(Potentilla fruticosa)

PRICKLY ROSE

(Rosa acicularis)

FORBS

BEARBERRY

(Arctostaphylos uva-ursi) 1

EARLY YELLOW LOCOWEED

(Oxytropis sericea) 3

FRINGED SAGE

(Artemisia frigida) $\quad 6 \quad 1-15 \quad 100$

AMERICAN VETCH

(Vicia americana)

NORTHERN BEDSTRAW

(Galium boreale)

$\begin{array}{lll}2 & 0-4 & 80 \\ 3 & 0-8 & 100\end{array}$

GRASSES

JUNEGRASS

(Koeleria macrantha) $\quad 5 \quad 3-7 \quad 100$

WESTERN WHEATGRASS

(Agropyron smithii)

WHITE SCALED SEDGE

(Carex xerantica)

ROUGH FESCUE

(Festuca scabrella) $\quad 3 \quad 0-6 \quad 80$

SLENDER WHEATGRASS

(Agropyron trachycaulum) 3
$0-2 \quad 20$

$1-4 \quad 100$

$0-9 \quad 60$

$1-14 \quad 100$

$0-9 \quad 80$

6-12 100

$0-7 \quad 60$
MOISTURE REGIME:

XERIC TO SUBXERIC

NUTRIENT REGIME:

SUBMESOTROPHIC

SLOPE: $53(45-60) \%$

ASPECT: SOUTHERLY

ELEVATION:

1790(1650-1900)M

SOIL DRAINAGE: RAPIDLY

Forage Production KG/Ha

Grass 1133(650-2206)

FORB 545(202-890)

SHRUB 250(0-556)

TOTAL 1928(936-3096)

SUGGESTED GRAZING CAPACITY

NON-USE

ENVIRONMENTAL VARIABLES 


\section{SACFA13. Sedge-Bog sedge-Tufted hairgrass (Carex praegracilis-Kobresia myosuroides-Deschampsia cespitosa)}

$\mathbf{n}=\mathbf{6}$ This community type is found on moist lowland sites at higher elevations in the Central and Northern Foothills. The presence of bog sedge appears to indicate the transition to the higher Alpine subregion. Indeed, Ogilvie (1969) described bog sedge dominated community types at higher elevations in the Alpine subregion.

The presence of bog sedge may also represent the transition between the foothills ecodistricts to the rocky mountain ecodistricts. Corns and Achuff (1982), described bog sedge dominated community types in the Subalpine subregion of Banff and Jasper National Parks.

The forage production on this community type is only moderate. Perhaps, the higher elevation and colder climate which favours the growth of bog sedge limits the total productivity of the site. Camping and grazing of these communities by horses should be restricted.

\section{Plant Composition Canopy Cover(\%)} MEAN RANGe CONST.

\section{SHRUBS}

SHRUBBY CINQUEFOIL.

(Potentilla fruticosa)

$1 \quad 0-4 \quad 67$

\section{FORBS}

ALPINE GOLDENROD

(Solidago multiradiata)

STRAWBERRY

(Fragaria virginiana)

GRACEFUL CINQUEFOIL

$\begin{array}{llll}\text { (Potentilla gracilis) } & 3 & 0-10 & 33\end{array}$

YARROW

$\begin{array}{llll}\text { (Achillea millefolium) } & 5 & 0-15 & 100\end{array}$

ALPINE BISTORT

(Polygonum viviparum) 6

SMOOTH LEAVED CINQUEFOIL

(Potentilla diversifolia) 12

$0-13 \quad 100$

$0-31 \quad 83$

\section{GRASSES}

GRACEFUL SEDGE

\begin{tabular}{|c|c|c|c|}
\hline (Carex praegracilis) & 40 & $14-60$ & 100 \\
\hline BOG SEDGE & & & \\
\hline (Kobresia myosuroides) & 20 & $10-28$ & 100 \\
\hline TUFTED HAIRGRASS & & & \\
\hline (Deschampsia cespitosa) & 13 & $5-37$ & 83 \\
\hline ROCKY MOUNTAIN FESCUE & & & \\
\hline (Festuca saximontana) & 3 & $0-10$ & 33 \\
\hline ALPINE BLUEGRASS & & & \\
\hline (Poa alpina $)$ & 2 & $0-13$ & 50 \\
\hline $\begin{array}{l}\text { HAIRY WILDRYE } \\
\text { (Elymus innovatus) }\end{array}$ & 7 & $0-30$ & \\
\hline
\end{tabular}

\section{ENVIRONMENTAL VARIABLES}

MoISTURE REGIME:

MESIC-SUBHYGRIC

\section{NUTRIENT REGIME:}

MESOTROPHIC

ELEVATION:

1900(1832-2438)M

SOIL DRAINAGE:

IMPERFECTLY

SLOPE:

$1 \%$

ASPECT:

NORTHEAST

\section{Forage Production KG/Ha}

\author{
GRASS 582 (310-1002) \\ FORB $158(58-272)$ \\ TOTAL $740(582-1060)$
}

SugGested GraZING CAPACITY

NON-USE 


\section{SACFA14. White mountain avens/Bog sedge \\ (Dryas integrifolia/Kobresia myosuroides)}

$\mathbf{n}=\mathbf{3}$ This community type occupies shallow, stoney, wind exposed sites. It represents the transitional community between the bog sedge and white mountain avens community types described by Ogilvie (1969) and Corns and Achuff (1982) on windswept ridges in the Alpine and Subalpine subregions of the Rocky Mountains. The microsite conditions are very similar to higher elevation sites in the Rocky Mountains allowing this community to form in the lower Central Foothills.

The poor soil conditions limits the forage productivity and amount of regrowth after grazing. Often this community type is important winter range for bighorn sheep, because this community type remains snow free for much of the winter.

\section{Plant CoMposition CANopy Cover(\%)} Mean Range CONST.

FORBS

WHITE MOUNTAIN AVENS

(Dryas integrifolia) $\quad 46 \quad 0-41 \quad 67$

ALPINE BISTORT

$\begin{array}{llll}\text { (Polygonum viviparum) } & 6 & 3-9 & 100\end{array}$

ALPINE HEDYSARUM

$\begin{array}{llll}\text { (Hedysarum alpinum) } & 2 & 0-4 & 100\end{array}$

ALPINE MILKVETCH

(Astragalus alpinum) $\quad 1 \quad 0-3 \quad 33$

GRASSES

BOG SEDGE

(Kobresia myosuroides) $11 \quad 1-32 \quad 100$

GRACEFUL SEDGE

(Carex praegracilis) $\quad 6 \quad 0-17 \quad 33$

HAIRY WILDRYE

$\begin{array}{llll}\text { (Elymus innovatus) } & 5 & 0-9 & 67\end{array}$

LICHENS

REINDEER LICHEN

(Cladina spp.)

$17 \quad 0-40$

67

\section{ENVIRONMENTAL VARIABLES}

MOISTURE REGIME: XERIC-SUBXERIC

NUTRIENT REGIME: SUBMESOTROPHIC

ELEVATION:

1912(1878-1981)M

SOIL DRAINAGE: RAPIDLY

SLOPE: $30 \%$

ASPECT: SOUTHERLY

Forage Production KG/HA

GRASS $517(89-945)$

FORB 245(200-290)

TOTAL 762(289-1235)
SUGGESTED GRAZING CAPACITY NON-USE 


\section{SACFA15. Creeping red fescue-Sedge}

(Festuca rubra-Carex spp.)

$\mathbf{n}=\mathbf{1} \quad$ This community type was described in the Blackstone-Wapiabi forest land use zone. It represents an old wellsite road that has been seeded to creeping red fescue. The creeping red fescue was probably used as the reclamation seed to stabilize the road from erosion. Presently, it is the recommendation of the forest service to use native seed in reclamation of these areas in the backcountry. Many of these agronomic mixes are highly invasive on the surrounding vegetation and there is the potential to introduce noxious weeds.

\section{Plant Composition CANopy Cover(\%) Mean Range Const.}

\section{SHRUBS}

WILLOW

(Salix barclayi)

1

100

\section{FORBS}

PaLmate LeaVed COLTSFOOT

(Petasites palmatus)

FIREWEED

(Epilobium angustifolium) 1

Grasses

CREEPING RED FESCUE

(Festuca rubra)

$63 \quad-\quad 100$

GRACEFUL SEDGE

(Carex praegracilis)

TUFTED HAIRGRASS

(Deschampsia cespitosa) 2

TIMOTHY

(Phleum pratense)

$38 \quad-\quad 100$

100

100

\section{ENVIRONMENTAL VARIABLES}

MOISTURE REGIME:

MESIC

NUTRIENT REGIME:

MESOTROPHIC

ELEVATION:

$1832 \mathrm{M}$

SOIL DRAINAGE:

WELL

SLOPE:

LEVEL

Forage Production KG/HA

GRASS 1705

FORB 15

TOTAL 1720

\section{SugGESTED GRAZING CAPACITY}

$0.6 \mathrm{HA} / \mathrm{AUM}$ OR $1.2 \mathrm{AC} / \mathrm{AUM}$ 


\section{SACFA16. Kentucky bluegrass-Sedge/Dandelion \\ (Poa pratensis-Carex spp./Taraxacum officinale)}

$\mathbf{n}=\mathbf{1}$ This community type was described in the Job Lake forest land use zone. It represents a Tufted hairgrassSedge meadow that has been heavily grazed for a prolonged period of time. As a result there has been a decline in tufted hairgrass and other native plant species and an invasion of Kentucky bluegrass and dandelion. This community type is uncommon in the backcountry areas because of the lack of seed source for Kentucky bluegrass and dandelion. However, once established it is very competitive and will likely remain on the site. Kentucky bluegrass is very productive, but it quickly loses it nutrient quality in the dormant season. This loss of nutrient quality will impact wildlife utilizing the area.

\section{Plant COMPOSITION Canopy Cover(\%)}

Mean Range Const.

SHRUBS

WILLOW

(Salix barclayi)

$$
1
$$

100

FORBS

ALPINE BISTORT

$\begin{array}{llll}\text { (Polygonum viviparum) } & 18 & - & 100\end{array}$

GRACEFUL CINQUEFOIL

(Potentilla gracilis) 8

SWEET FLOWERED ANDROSACE (Androsace chamaejasme) 3

ALPINE MILKVETCH

(Astragalus alpinus) $\quad 3 \quad-\quad 100$

MOUSE EARED CHICKWEED

(Cerastium arvense)

\section{GRASSES}

KENTUCKY BLUEGRASS

\section{(Poa pratensis)}

36

GRACEFUL SEDGE

(Carex praegracilis)

SLENDER WHEATGRASS

(Agropyron trachycaulum) 5

100

100

100

100

\section{ENVIRONMENTAL VARIABLES}

\author{
MOISTURE REGIME: \\ MESIC
}

NUTRIENT REGIME:

PERMESOTROPHIC

ELEVATION:

$1832 \mathrm{M}$

Forage Production Kg/Ha

GRASS 380

FORB 224

TOTAL 604

SugGESTED GRAZING CAPACITY

$1.5 \mathrm{HA} / \mathrm{AUMM}$ OR $3.4 \mathrm{AC} / \mathrm{AUM}$ 


\section{SACFA17. Fireweed-Meadow rue/Sedge \\ (Epilobium angustifolium-Thalictrum venulosum/Carex spp.)}

$\mathbf{n}=\mathbf{1} \quad$ This community type was described in the Panther Corners forest land use zone adjacent to an abandoned air strip. The site was a moist site with a higher nutrient regime making it highly productive. This community type had not been extensively utilized by horses or wildlife and appears to be undergoing succession to a shrub dominated community type. Some invasion of agronomic species (smooth brome, bluegrass spp.) has occurred off the old airstrip into this community type.

\section{Plant Composition CANopy Cover(\%)}

MEAN RANGE CONST.

SHRUBS

WILLOW

(Salix spp.)

$\mathrm{T}$

100

\section{FORBS}

FIREWEED

(Epilobium angustifolium) 37

VEINY MEADOW RUE

(Thalictrum venulosum) $22 \quad-\quad 100$

YARROW

(Achillea millefolium) $13 \quad-\quad 100$

AMERICAN VETCH

(Vicia americana)

NORTHERN BEDSTRAW

(Galium boreale)

5

$$
4
$$

GraSSES

BLUEGRASS

(Poa spp.)

SEDGE

(Carex spp.)

SLENDER WHEATGRASS

(Agropyron trachycaulum)

SMOOTH BROME

(Bromus inermis)

HAIRY WILDRYE

(Elymus innovatus)
100

100

100

100

100

100

100

100

\section{ENVIRONMENTAL VARIABLES}

MoIsture Regime: SubHYGRIC

NUTRIENT REGIME:

PERMESOTROPHIC

ELEVATION: $1650 \mathrm{M}$

SOIL DRAINAGE:

MODERATELY WELL

SLOPE: LEVEL

\section{Forage Production}

GRASS 1006

FORB 2134

TOTAL 3140

\section{SUGGESTED GRAZING CAPACITY}

$0.3 \mathrm{HA} / \mathrm{AUM}$ OR $0.7 \mathrm{AC} / \mathrm{AUM}$ 


\section{SACFB1. Willow-Bog birch/Water sedge \\ (Salix spp.-Betula glandulosa/Carex aquatilis)}

$\mathbf{n}=9$ This shrub community appears on areas with very poor drainage. It is found in association with the wetter water sedge meadows. These sites are fairly productive but difficult to graze due to the moist ground conditions and heavy shrub cover which reduces access and mobility within the area. Increased flooding and prolonged waterlogging may result in the disappearance of willow and a transition to a water sedge meadow.

This community is similar to the water sedge-beaked sedge community in that it is found throughout the foothills and into the mountains. It maybe found in the Upper Foothills, Subalpine and lower Alpine subregions.

Plant Compositioncanopy Cover(\%) Mean Range CONST.

SHRUBS

WILLOW

(Salix spp)

30

$1-67$

100

BOG BIRCH

(Betula glandulosa)

18

$0-44$

100

FORBS

ELEPHANT'S HEAD

$\begin{array}{llll}\text { (Pedicularis groenlandicum) } & 1 & 0-6 & 78\end{array}$

(Aster laevis)

$2 \quad 0-8 \quad 56$

ALPINE BISTORT

(Polygonum viviparum) 1

SMOOTH LEAVED CINQUEFOIL

(Potentilla diversifolia) 2

ENTIRE LEAVED GROUNDSEL

(Senecio lugens)

2

$0-6$

$0-15 \quad 33$

$0-13 \quad 22$

GRASSES

WATER SEDGE

(Carex aquatilis)

32

$0-91$

67

TUFTED HAIRGRASS

(Deschampsia cespitosa) 4

GRACEFUL SEDGE

(Carex praegracilis) 2

BALTIC RUSH

(Juncus balticus)

5

$0-26 \quad 89$

$0-20 \quad 11$

$0-17 \quad 56$

\section{ENVIRONMENTAL VARIABLES}

MOISTURE REGIME :

HYGRIC

NUTRIENT REGIME:

PERMESOTROPHIC

ELEVATION:

1760(1600-1950) M

SOIL DRAINAGE:

MODERATELY WELL TO POORLY

SLOPE:

$6(2-5) \%$

ASPECT:

SOUTHEASTERLY

Forage Production Kg/Ha

$$
\begin{array}{ll}
\text { GRASS } & 1234(500-2320) \\
\text { FORBS } & 129(0-354) \\
\text { SHRUB } & 1150(0-2990) \\
\text { TOTAL } & 2514(1870-3848)
\end{array}
$$




\section{SACFB2. Willow/Horsetail \\ (Salix spp./ Equisetum spp.)}

$\mathbf{n}=4$ This community type occupies level to gently sloping, fluvial landforms at lower elevations in the subalpine. The sites are hygric and imperfectly to poorly drained. This community borders rivers and streams and is transitional to the spruce, subalpine fir, horsetail dominated forest.

\section{Plant COMPOSITION CANOPY COVER(\%)} MEAN RANGe CONST.

\section{SHRUBS}

WILLOW SPP.

(Salix spp.)

BOG BIRCH

(Betula glandulosa)

$$
32
$$$$
5-56
$$

100

$5 \quad 0-20 \quad 60$

\section{FORBS}

VARIEGATED HORSETAIL

(Equisetum variegatum) 10

COMMON HORSETAIL

(Equisetum arvense) $\quad 10$

WOOLLY EVERLASTING

(Antennaria lanata)

1

GRASSES

SEDGE SPP.

(Carex spp.)

$14 \quad 3-25 \quad 100$

TUFTED HAIRGRASS

(Deschampsia cespitosa) 1

$0-3 \quad 60$

\section{ENVIRONMENTAL VARIABLES}

MOISTURE REGIME :

SUBHYGRIC

NUTRIENT REGIME:

PERMESOTROPHIC

ELEVATION:

1512(1260-1810) M

SOIL DRAINAGE:

POORLY

\section{Forage Production KG/Ha}

None AVAILABLE

Suggested Grazing Capacity NON-USE 


\section{SACFB3. Willow/Graceful sedge \\ (Salix spp./ Carex praegracilis)}

$\mathrm{n}=6$ This community type appears to represent a stage of succession onto tufted hairgrass meadows. When these communities are protected from disturbance (fire and grazing) willow and bog birch expand and tufted hairgrass declines. Willow growth also appears to favour the growth of tall forbs (veiny meadow rue, fireweed, aster) and slender wheatgrass. Fire has played a dominant role in controlling brush encroachment in the past and continued protection will allow continued shrub expansion, resulting in a decline in forage production.

\section{Plant CoMposition Canopy Cover(\%)} Mean Range CONST.

\section{SHRUBS}

WILLOW SPP.

(Salix spp.)

BOG BIRCH

(Betula glandulosa)

$$
35
$$

$18-55 \quad 100$

$0-3 \quad 50$

FORBS

SMOOTH LEAVED CINQUEFOIL

(Potentilla diversifolia) 8

STRAWBERRY

$\begin{array}{llll}\text { (Fragaria virginiana) } \quad 4 & 0-17 & 50\end{array}$

YARROW

$\begin{array}{llll}\text { (Achillea millefolium) } & 2 & 0-8 & 83\end{array}$

ALPINE BISTORT

(Polygonum viviparum) 2

SMALL LEAVED EVERLASTING

(Antennaria parviflora) 10

MEADOW RUE

$\begin{array}{llll}\text { (Thalictrum venulosum) } & 3 & 0-15 & 17\end{array}$

GraSSES

GRACEFULSEDGE

(Carex praegracilis)

TUFTED HAIRGRASS

(Deschampsia cespitosa) $9 \quad 0-41 \quad 67$

SLENDER WHEATGRASS

(Agropyron trachycaulum) $3 \quad 0-13 \quad 33$

SPIKED TRISETUM

(Trisetum spicatum)
50

$35-73 \quad 100$

$0-16 \quad 33$

\section{ENVIRONMENTAL VARIABLES}

MOISTURE REGIME:

SUBHYGRIC

NUTRIENT REGIME:

PERMESOTROPHIC

ELEVATION:

1876(1832-1985) M

SOIL DRAINAGE:

POORLY

\section{Forage Production Kg/Ha}

GRASS 806(380-1369)

FORBS 109(52-224)

SHRUBS 3(0-10)

TOTAL 919(604-1421)

SUGGESTED GRAZING CAPACITY

$1.0 \mathrm{HA} / \mathrm{AUM}$ OR $2.2 \mathrm{AC} / \mathrm{AUM}$ 


\section{SACFB4. Willow-Bog birch/Tufted hairgrass \\ (Salix glauca-Betula glandulosa/Deschampsia cespitosa)}

$\mathbf{n}=\mathbf{1 4}$ This community type is found in association with the Tufted hairgrass-Sedge c.t.. Willow encroachment into a tufted hairgrass meadow eventually results in this community type. Historically fire has played an important role in the maintenance of the grassland community type in this ecoregion. Continued fire suppression will eventually allow willow and bog birch to invade many of these grassy meadows.

Willoughby (1998) found that the encroachment of willow into the Tufted hairgrass-Sedge c.t. caused a decline in forage production from $2200 \mathrm{~kg} / \mathrm{ha}$ to $1800 \mathrm{~kg} / \mathrm{ha}$ in the Upper Foothills subregion. This community has a high cover of willow and very little forage for domestic livestock.

\section{Plant COMPOSITION CANOPY COVER(\%)}

\section{SHRUBS}

SMOOTH WILLOW .

(Salix glauca)

BARRET'S WILLOW

(Salix barrattiana)

BOG BIRCH

(Betula glandulosa)

10. $0-25$

79

\section{FORBS}

YARROW

(Achillea millefolium)

1

(Fragaria virginiana)

LINDLEY'S ASTER

(Aster ciliolatus)

MOUNTAIN HELIOTROPE

(Valeriana sitchensis)

TALL LARKSPUR

(Delphinium glaucum)

WANDERING DAISY

(Erigeron peregrinus)

26

0-65

86

$6 \quad 0-55$

43

GRASSES

TUFTED HAIRGRASS

(Deschampsia cespitosa)

HAIRY WILDRYE

(Elymus innovatus)

SEDGE

(Carex spp.)
19

2-35

100

$2 \quad 0-5 \quad 36$

10

$0-5 \quad 36$
$0-3$

43

$0-20 \quad 36$

$0-20 \quad 36$

$0-35 \quad 43$

$0-5 \quad 43$

$0-15 \quad 29$
0-26 86

\section{ENVIRONMENTAL VARIABLES}

MOISTURE REGIME :

MESIC TO SUBHYGRIC

NUTRIENT REGIME :

PERMESOTROPHIC

ELEVATION:

1828(1220-2210) M

SOIL DRAINAGE :

MOD. WELL

Forage Production Kg/Ha

GRASS 950

FORBS 493

SHRUBS 265

Total $1803 *$ Estimate

\section{SUGGESTED GRAZING CAPACITY}

$0.5 \mathrm{HA} / \mathrm{AUM}$ OR $1.1 \mathrm{ACRES} / \mathrm{AUM}$ 


\section{SACFB5. Willow-Bog birch/Clover-Dandelion (Salix glauca-Betula glandulosa/Trifolium repens-Taraxacum officinale)}

$\mathbf{n}=\mathbf{1}$ This community type represents a Willow-Bog birch/Tufted hairgrass community that has been extensively grazed by horses. This community was described near a historic campsite in the South Ram river drainage. Longterm moderate grazing pressure or heavy grazing pressure over a couple of years causes tufted hairgrass to decline and allows sedge, slender wheatgrass, Kentucky bluegrass, clover and dandelion to increase (Willoughby 2001) These community types are highly productive for domestic livestock throughout the growing season, but the poor quality of Kentucky bluegrass, clover and dandelion, particularly, in the dormant season limits the use of these community types for wildlife.

\section{PLANT COMPOSITION CANOPY COVER(\%) Mean Range Const.}

\section{SHRUBS}

SMOOTH WILLOW .

(Salix glauca)

BOG BIRCH

(Betula glandulosa)

$\begin{array}{lll}19 & - & 100 \\ 10 & - & 100\end{array}$

\section{FORBS}

YARROW

(Achillea millefolium)

$11 \quad-\quad 100$

(Fragaria virginiana)

4

DANDELION

(Taraxacum offincinale)

Clover

(Trifolium repens)

GRACEFUL CINQUEFOIL

(Potentilla gracilis)

\section{ENVIRONMENTAL VARIABLES}

MOISTURE REGIME:

MESIC

NUTRIENT REGIME :

MESOTROPHIC

ELEVATION:

$1966 \mathrm{M}$

SOIL DRAINAGE :

MOD. WELL

SLOPE:

$$
2 \%
$$

ASPECT:

Forage Production KG/Ha

TUFTED HAIRGRASS

(Deschampsia cespitosa) 10

SLENDER WHEATGRASS

(Agropyron trachycaulum)6 $\quad$ - $\quad 100$

SEDGE

100

(Carex spp.)

12

KENTUCKY BLUEGRASS

(Poa pratensis)

100

HAIRY WILDRYE

7

(Elymus innovatus)

\section{SOUTHEAST}

100

100

GRASS 1728

FORBS 199

TOTAL 1927
SUGGESTED GRAZING CAPACTIY
$0.5 \mathrm{HA} / \mathrm{AUM}$ OR 1.1 ACRES/AUM 


\section{SACFB6. Willow-Bog birch/California oatgrass \\ (Salix glauca-Betula glandulosa/Danthonia californica)}

$\mathbf{n}=19$ This community type likely develops from willow encroaching onto an oatgrass dominated meadow. The oatgrass meadows are found on dry, gravelly soils. These meadows may also form in frost pockets. The spread of willow is likely caused by lack of natural disturbance, such as fire. The cover of willow on this community type is fairly extensive. This will restrict access to domestic livestock. This community type would be rated as secondary range.

\section{Plant COMPOSITION CANopy COVER(\%) \\ MEAN RANGe CONST.}

\section{SHRUBS}

SMOOTH WILLOW

(Salix glauca)

BARRET'S WILLOW

(Salix barratiana)

BOG BIRCH

(Betula glandulosa)

FORBS

YARROW

(Achillea millefolium)

MOUNTAIN CINQUEFOIL

(Potentilla diversifolia) 63

WILD STRAWBERRY

\section{(Fragaria virginiana)}

WANDERING DAISY

(Erigeron peregrinus)

GLOBEFLOWER

(Trollius albiflorus)

NORTHERN VALERAIN

(Valeriana dioica)
GRASSES

CALIFORNIA OATGRASS

(Danthonia californica) $\quad 24 \quad 10-70 \quad 100$

SEDGE

(Carex spp.)

$4 \quad 0-21 \quad 68$

MOUNTAIN TIMOTHY

(Phleum commutatum)

HAIRY WILD RYE

(Elymus innovatus)

SPIKED TRISTEUM

(Trisetum spicatum)
22

$0-75$

90

8

$0-50$

47

7
$0-50 \quad 58$

2

$0-9$

68

$1 \quad 0-6$

$9 \quad 0-33 \quad 90$

1

2

$0-25$

26

$0-8 \quad 21$

$1 \quad 0-8 \quad 21$

$4 \quad 0-35 \quad 68$

$1 \quad 0-15 \quad 32$

$3 \quad 0-20 \quad 68$

\section{ENVIRONMENTAL VARIABLES}

MOISTURE REGIME :

MESIC-SUBHYGRIC

NUTRIENT REGIME:

MESOTROPHIC

ELEVATION:

1888(1360-2340) M

SOIL DRAINAGE:

MODERATELY WELL TO WELL

\section{Forage Production KG/Ha}

$\begin{array}{ll}\text { GRASS } & 598 \\ \text { FORBS } & 418 \\ \text { SHRUBS } & 300 \\ \text { TOTAL } & 1316 * \text { ESTIMATE }\end{array}$

\section{Suggested GRAZING CAPACITY}

$0.7 \mathrm{HA} / A U M$ OR 1.5 ACRES/AUM 


\section{SACFB7. Willow-Bog birch/Hairy wildrye (Salix glauca-Bog birch/Elymus innovatus)}

$\mathbf{n}=\mathbf{2 0}$ This community is typical of the valley bottoms where the low temperatures prohibit the growth of trees. Corns and Achuff (1982) described a similar community in the Banff and Jasper National Parks. They found this community type occupied coarse stream deposits which had repeated flooding.

Bork (1994) felt this community type developed from the invasion of willow and bog birch onto grasslands in the absence of disturbance in Willmore Wilderness park. Willow cover has increased, shading the growth of grasses and allowing tall-growing forbs, such as fireweed, aster and veiny meadow rue to increase. He felt continued protection from disturbance will allow succession to shrub and eventually tree species, which will increase shading of the understory vegetation and eventually lower forage production.

\section{Plant COMPOSITION CANopy Cover(\%) Mean Range CONST.}

TREES

WHITE SPRUCE

(Picea glauca)

$\mathrm{T}$

$0-3 \quad 5$

\section{SHRUBS}

WILLOW SPP.

(Salix glauca)

BOG BIRCH

(Betula glandulosa)

30

$8-52$

100

24

$2-58 \quad 90$

\section{FORBS}

NORTHERN VALERIAN

(Valeriana dioica)

YARROW

(Achillea millefolium)

FIREWEED

(Epilobium angustifolium) 3

STRAWBERRY

(Fragaria virginiana) $\quad 4 \quad 0-12 \quad 80$

TALL LARKSPUR

(Delphinium glaucum) $3 \quad 0-10 \quad 85$

\section{GRASSES}

BOG SEDGE

(Kobriesia myosuroides) $5 \quad 0-16 \quad 55$

HAIRY WILDRYE

(Elymus innovatus) $\quad 10 \quad 0-30 \quad 95$

GRACEFUL SEDGE

(Carex praegracilis)

SLENDER WHEATGRASS

(Agropyron trachycaulum) 3

\section{ENVIRONMENTAL VARIABLES}

MOISTURE REGIME:

XERIC TO SUBHYGRIC

NUTRIENT REGIME:

MESOTROPHIC

ELEVATION:

1926(1560-2250) M

SOIL DRAINAGE:

RAPIDLY TO MODERATELY WELL

SLOPE:

$3(1-10) \%$

ASPECT:

EASTERLY

Forage Production Kg/HA

$\begin{array}{ll}\text { GRASS } & 868(756-1003) \\ \text { FORBS } & 713(85-2120) \\ \text { SHRUB } & 135(0-540) \\ \text { TOTAL } & 1716(1088-2898)\end{array}$

SUGGESTED GRAZING CAPACITY

$0.5 \mathrm{HA} / \mathrm{AUM} 1.2 \mathrm{AC} / \mathrm{AUM}$ 


\section{SACFB8. Bog birch/Bog sedge-Sedge \\ (Betula glandulosa/Kobresia myosuroides-Carex spp.)}

$\mathbf{n = 5}$ This community type was described on moist lowland sites at higher elevations in the Central and Northern foothills ecodistricts. It appears this community type originated from recent shrub encroachment onto sedge-bog sedge-tufted hairgrass community type. The presence of bog sedge may represent the transition between the foothills ecodistricts and the rocky mountain ecodistricts. Corns and Achuff(1982) described bog sedge dominated community types in the Central and Northern Rocky Mountains of the Subalpine subregion of Banff and Jasper National Parks. Camping and grazing of these communities by horses should be restricted.

\section{Plant Composition CANOpy Cover(\%)}

\section{SHRUBS}

\section{MEAN RANGe CONST.}

WILLOW SPP.

$\begin{array}{llll}\text { (Salix spp.) } & 3 & 0-10 & 60 \\ \begin{array}{l}\text { BOG BIRCH } \\ \text { (Betula glandulosa) }\end{array} & 27 & 12-40 & 100\end{array}$

\section{FORBS}

SLENDER Blue BEARdTONGUe

$\begin{array}{llll}\text { (Penstemon procerus) } & 3 & 1-7 & 100\end{array}$

BEARBERRY

(Arctostaphylos uva-ursi) 4

SMOOTH LEAVED CINQUEFOIL

(Potentilla diversitolia) 5

OLD MAN'S WHISKERS

(Geum triflorum)

ALPINE GOLDENROD

(Solidago multiradiata) $2 \quad 0-5 \quad 60$

GRASSES

BOG SEDGE

(Kobresia myosuroides) $26 \quad 16-45 \quad 100$

GRACEFUL SEDGE

(Carex praegracilis) $\quad 16 \quad 0-41 \quad 80$

SLENDER WHEATGRASS

(Agropyron trachycaulum) 9

CALIFORNIA OATGRASS

(Danthonia californica) $\quad 5 \quad 0-12 \quad 80$

\section{ENVIRONMENTAL VARIABLES}

MoISTURE REGIME:

MESIC-SUBHYGRIC

NUTRIENT REGIME: MESOTROPHIC

ELEVATION:

1791(1530-2286) M

SOIL DRAINAGE:

MODERATELY WELL

SLOPE: $2(1-2) \%$

ASPECT: EASTERLY

Forage Production KG/Ha

GRASS 1333(391-2848)

FORBS 390(88-695)

SHRUBS 202(0-807)

TOTAL 1925(683-3416) 


\section{SACFB9. Bog birch-Willow/Rough fescue \\ (Betula glandulosa-Salix spp./Festuca scabrella)}

$\mathbf{n}=\mathbf{4}$ This community type is very similar to the Bog birch/Rough fescue-Sedge community described by Willoughby (1992) in the Upper Foothills subregion. Willoughby found that the rough fescue grasslands were located upslope of tufted hairgrass meadows on slightly drier, gravelly soils. Bork (1994), also described rough fescue dominated grasslands in Willmore Wilderness Park. This community type is also similar to the Bog birch/Rough fescue-Bog sedge community type but lacks the cover of bog sedge. Bog sedge tends to grow at higher elevations and appears to indicate the transition from the Upper Foothills subregion to the Subalpine subregion.

It appears the lack of fire on this community type has allowed the shrub cover to expand, reducing forage productivity for wildlife and domestic livestock. In one study, burning a Bog birch/Rough fescue community type twice in 3 year intervals controlled birch growth and increased total forage production by over $40 \%$ compared to the unburned control in the Upper Foothills subregion (Bork 1990).

\section{Plant COMPOSITION CANopy COVER(\%)}

mean Range Const.

\section{SHRUBS}

BOG BIRCH

\begin{tabular}{|c|c|c|}
\hline (Betula glandulosa) & 39 & $24-62$ \\
\hline $\begin{array}{l}\text { WILLOW SPP. } \\
\text { (Salix spp) }\end{array}$ & & $0-26$ \\
\hline
\end{tabular}

\section{FORBS}

\section{AMERICAN VETCH}

(Vicia americana)

SMOOTH ASTER

(Aster laevis)

TALL LARKSPUR

(Delphinium glaucum)

OLD MAN'S WHISKERS

(Geum triflorum)

FIREWEED

(Epilobium angustifolium) 3

\section{GRASSES}

ROUGH FESCUE

(Festuca scabrella)

GRACEFUL SEDGE

(Carex praegracilis)

SLENDER WHEATGRASS

(Agropyron trachycaulum) 9

HAIRY WILDRYE

(Elymus innovatus)

\section{ENVIRONMENTAL VARIABLES}

MOISTURE REGIME:

MESIC

\section{NUTRIENT REGIME: MESOTROPHIC}

ELEVATION: $1675(1600-1750) \mathrm{M}$

\section{SOIL DRAINAGE:} WELL

\section{SLOPE:}

$$
5 \%
$$

\section{ASPECT:}

VARIABLE

\begin{tabular}{cc} 
FORAGE PRODUCTION KG/HA \\
\hline GRASS & $1807(642-3564)$ \\
FORBS & $705(492-902)$ \\
SHRUBS & $559(170-800)$ \\
TOTAL & $3071(2070-4226)$
\end{tabular}

\section{SUGGESTED GRAZING CAPACITY $0.4 \mathrm{HA} / \mathrm{AUMM}$ OR0. 8 ACRES/AUM}




\section{SACFB10. Bog birch/Rough fescue-Bog sedge \\ (Betula glandulosa/Festuca scabrella-Kobresia myosuroides)}

$\mathbf{n = 1}$ This community type is very similar to the Bog birch-Willow/Rough fescue community previously described. Willoughby(2001) found that the rough fescue grasslands were located upslope of tufted hairgrass meadows on slightly drier, gravelly soils. Bork (1994), also described rough fescue dominated grasslands in Willmore Wilderness Park. The presence of bog sedge in this community type appears to indicate the transition from the Upper Foothills and lower Subalpine subregions to the Upper subalpine subregion.

It appears the lack of fire on this community type has allowed the shrub cover to expand, reducing forage productivity for wildlife and domestic livestock. In one study, buming a Bog birch/Rough fescue community type twice in 3 year intervals controlled birch growth and increased total forage production by over $40 \%$ compared to the unburned control in the Upper Foothills subregion (Bork 1990).

Plant Composition Canopy Cover(\%) MEAN RANGe CONST.

SHRUBS

BOG BIRCH

(Betula glandulosa)

WILLOW SPP.

(Salix barclayi)

FORBS

FALSE DANDELION

(Agoseris glauca)

GRACEFUL CINQUEFOIL

(Potentilla gracilis)

TALL LARKSPUR

(Delphinium glaucum)

ALPINE GOLDENROD

(Solidago multiradiata)

SHOW LOCOWEED

(Oxytropis splendens)

30

5

100

100

GRASSES

ROUGH FESCUE

(Festuca scabrella)

GRACEFUL SEDGE

(Carex praegracilis)

SLENDER WHEATGRASS

(Agropyron trachycaulum) 34

BOG SEDGE

(Kobresia myosuroides) 13

100

100

100

\section{ENVIRONMENTAL VARIABLES}

MOISTURE REGIME:

MESIC

NUTRIENT REGIME:

MESOTROPHIC

ELEVATION:

$1981 \mathrm{M}$

SOIL DRAINAGE:

WELL

GRASS

1201

FORBS 147

SHRUBS 0

TOTAL 1348

SUGGESTED GRAZING CAPACITY

$0.7 \mathrm{HA}$ AUM OR 1.6 ACRES/AUM

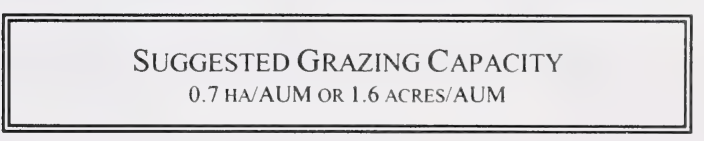




\section{SACFB11. Willow/Fringed brome-Sedge (Salix barclayi/Bromus ciliatus-Carex spp.)}

$\mathbf{n}=\mathbf{1}$ This community was described on the banks of Forbidden Creek west of Rocky Mtn. House where the water table is high but flooding is rare. It occupies the fluvial terraces along the creek. A similar community type Willow/Fringed brome-Slender wheatgrass was described in the Lower Foothills subregion (Lane et al. 2000). The production of the Lower Foothills type averaged over $1700 \mathrm{~kg} / \mathrm{ha}$. This community type had only half the production $(760 \mathrm{~kg} / \mathrm{ha})$. The more extreme climatic conditions of this site in the subalpine likely limits the growth of forage.

\section{Plant Composition Canopy Cover(\%)} MEAN RANGe CONST.

\section{SHRUBS}

WILLOW SPP. (Salix barclayi)

100

\section{FORBS}

YARROW

(Achillea millefolium)

GRACEFUL CINQUEFOIL

(Potentilla gracilis)

ALPINE BISTORT

(Polygonum viviparum)

OLD MAN'S WHISKERS

(Geum triflorum)

8

\section{Grasses}

FRINGED BROME

(Bromus ciliatus)

GRACEFUL SEDGE

(Carex praegracilis)

ROUGH FESCUE

(Festuca scabrella)

SLENDER WHEATGRASS

(Agropyron trachycaulum) 15

100

100

100

100

100

100

100

\section{ENVIRONMENTAL VARIABLES}

MOISTURE REGIME:

MESIC

NUTRIENT REGIME:

MESOTROPHIC

ELEVATION:

$2286 \mathrm{M}$

\section{Forage Prduction KG/HA}

$\begin{array}{ll}\text { GRASS } & 472 \\ \text { FORBS } & 288 \\ \text { TOTAL } & 760\end{array}$

SUGGESTED GRAZING CAPACITY

$1.1 \mathrm{HA} / A U M$ OR 2.4 ACRES/AUM 


\title{
CENTRAL AND NORTHERN ROCKY MOUNTAINS
}

\author{
NATIVE GRASSLANDS AND SHRUBLANDS
}

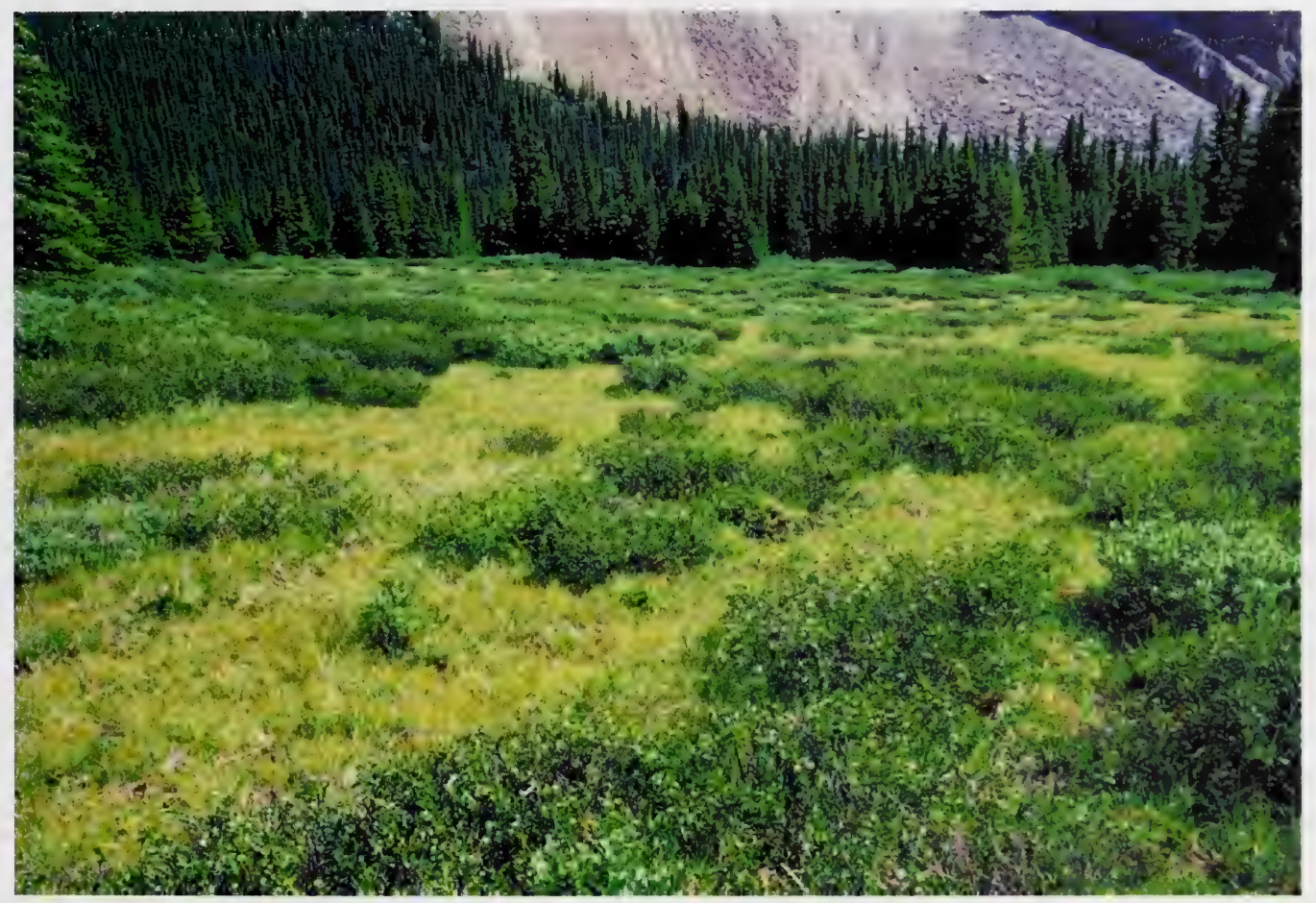

Figure 3. The presence of bog sedge in this Willow-Bog birch/Bog sedge community indicates the transition to the higher and steeper Central and Northern Rocky Mountains of the Subalpine subregion. Note the transition from the Subalpine to Alpine subregions in the background. 


\section{Native grass and shrubland ecology Mountain ecodistricts}

The native grass and shrubland community types in the Central and Northern Rocky Mountains of the Subalpine subregion (Table 3) are found in the valley bottoms adjacent to streams and rivers. The tufted hairgrass, California oatgrass and rough fescue dominated community types described previously in the foothills can also be found in the mountains, but these grassland community types are more common in the foothills and therefore were described in that section of the guide.

There are a number of grassland community types in the Central and Northern Rocky Mountains which are unique and appear to represent a transition from the lower subalpine mountain ecodistricts to the Alpine subregion. These include the hairy wildrye, junegrass and shrubby cinquefoil dominated community types (SACMA3,4,5,6) which are found on steep south facing slopes, at higher elevations throughout the mountains (Figure 2). Near lunberline there is a unique forb dominated (globeflower,wandering daisy, mountain marigold, mountain heliotrope) community type found on imperfectly to well drained sites. The presence of bog sedge (Kobresia myosuroides) in the Bog sedge-California oatgrass community type appears to indicate the transition from the lower Central and Northern Rocky Mountains to the Alpine subregion. Ogilvie (1969) and Corns and Achuff (1982), described bog sedge dominated community types in the higher elevations of the subalpine and alpine of the Rocky Mountains of Banff and Jasper National Parks.

The maintenance of the grassland community types in the mountains is extremely fire dependent. The lack of fire quickly allows bog birch and willow to expand shading the modal grassland community types. Prolonged shading causes the understory composition to shift from a tufted hairgrass-California oatgrass dominated understory to a slender wheatgrass-hairy wildrye dominated understory. Under a heavy shrub cover there is little forb or grass cover. The sequence of the grassland and shrubland community types unique to the mountain ecodistricts is outlined in figures 2 and 4 . These figures represent the transition from willow, bog birch dominated communities in the valley bottoms to the grass and dwarf shrublands in the upper Subalpine and Alpine subregions.

Many of these subalpine grass and shrublands are very fragile because of exposure and cold climate. The forage productivity is generally only half of what is found in the lower Upper Foothills subregion and recovery from overgrazing will likely take some time because of the poor growing conditions. As a result grazing by domestic livestock should be done with caution. 


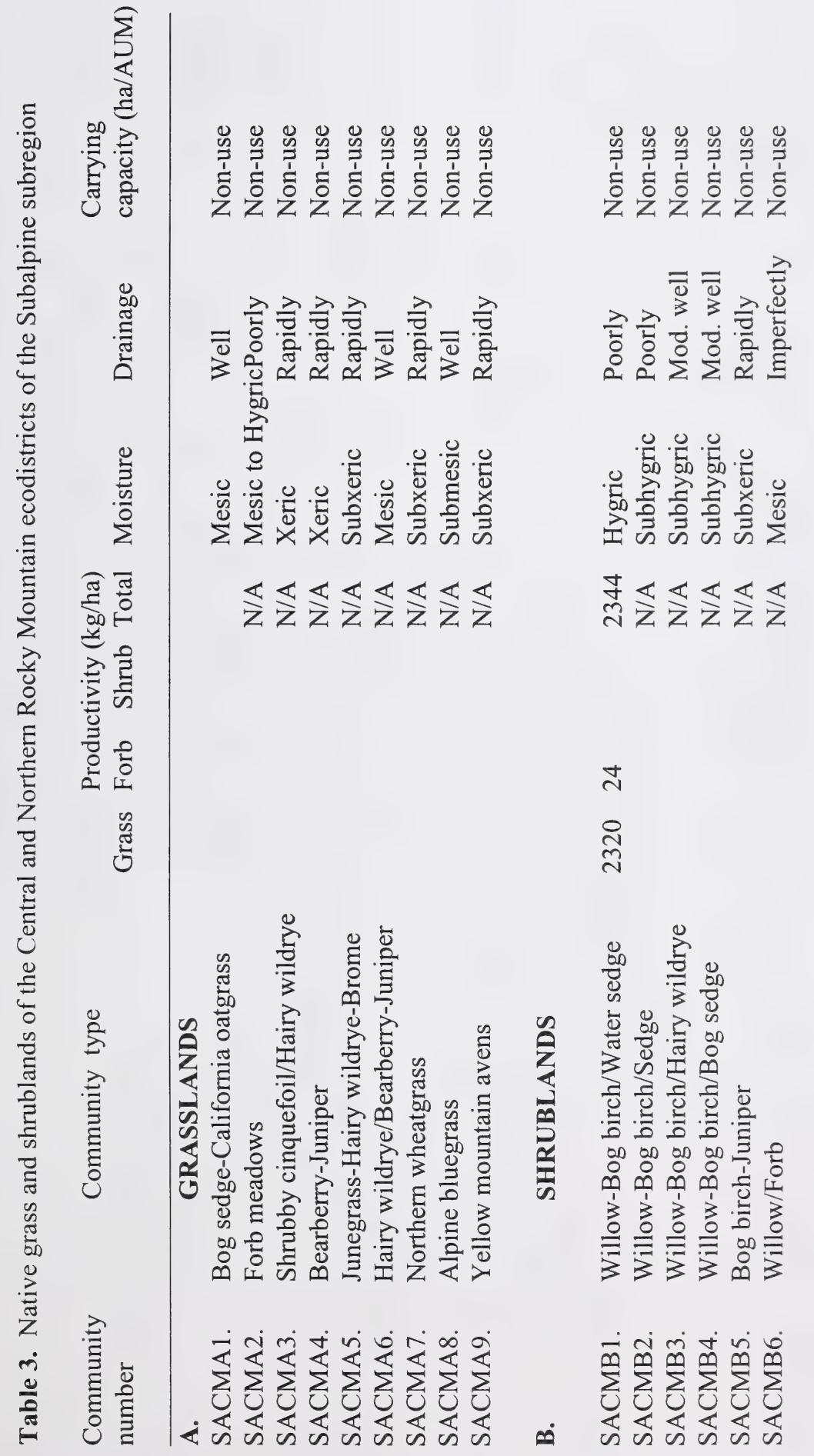




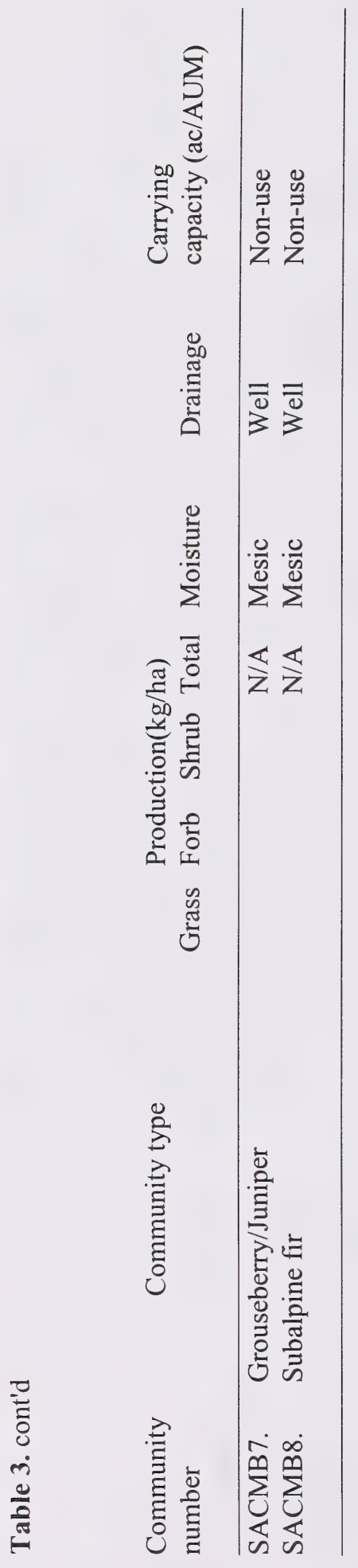




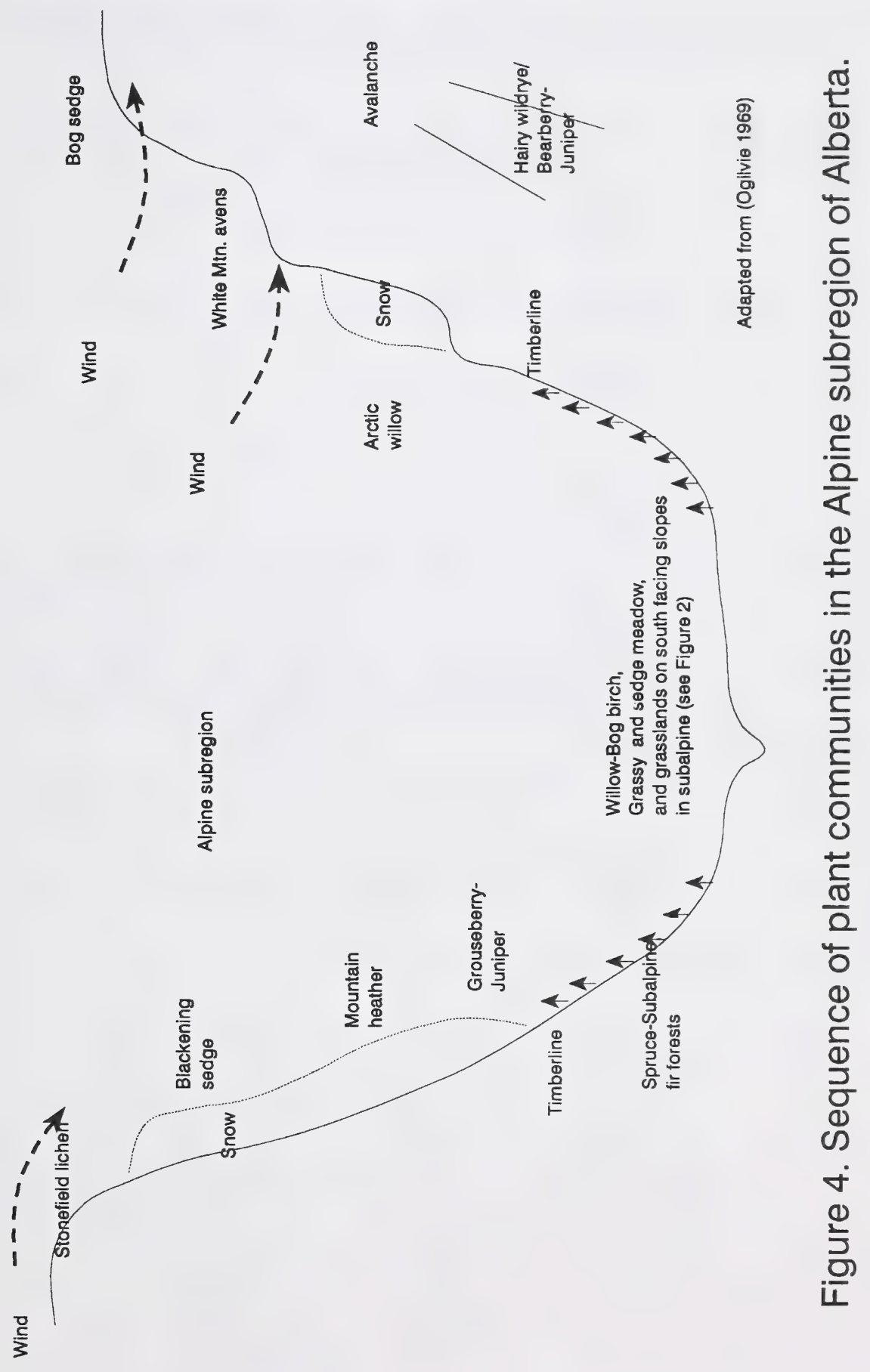




\section{Native grass and shrublands in Central and Northern Mountain and Foothills areas}

1. Community above timberline (Alpine subregion)..........Alpine section of guide

Community not above timberline, meadows, shrublands or south facing slopes dominated by shrubs and grass

2

2. Moist sites, community dominated by shrubs $>20 \%$ cover (willow, bog birch) or timberline communities with dwarf trees or grouseberry .................................. see shrub key pg 34

Drier to moist sites shrub cover $<10 \%$ site dominated by grasses and forbs......

3. Community very wet free standing water, dominated by sedge, cottongrass or tufted bulrush

Community drier, dominated by tufted hairgrass, rough fescue, california oatgrass, hairy wildrye, juniper or bearberry......

4. Very wet nutrient rich sites dominated by water or beaked sedge.

SACFA1

Very wet nutrient poor, acidic sites dominated by tufted bulrush and cottongrass..............

5. Site dominated by tufted bulrush.

SACFA2

Site dominated by cottongrass and sedge.

SACFA3

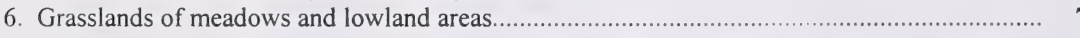

Grasslands of south facing slopes, or windswept ridges, hairy wildrye, bearberry, white mtn. avens dominated

20

7. Higher elevation sites near or at timberline, moist sites dominated by wandering daisy, globeflower, mountain marigold. SACMA2

Lower elevation sites, valley bottoms adjacent to streams or rivers or if higher elevation dry sites dominated by bog sedge

8

8. Disturbed or grazed community types dominated by Kentucky bluegrass, creeping red fescue, dandelion, alpine bluegrass, alpine timothy or fireweed.

Undisturbed community types dominated by rough fescue, California oatgrass, bog sedge, tufted hairgrass, and sedge species..

14

9. Moderately grazed site native increasers dominant (slender wheatgrass, sedge, fringed brome, rocky mtn. fescue, alpine

timothy), Alpine or Kentucky bluegrass increasing in cover....

10

Heavily grazed sites dominated by Kentucky bluegrass or abandoned airstrips dominated by creeping red fescue or native

forb species (fireweed, veiny meadow rue).

10. Site dominated by Alpine bluegrass.

SACMA8

Site dominated by rocky mtn. fescue, alpine timothy, sedge, slender wheatgrass, fringed brome (moister sites).

SACFA6

1. Site dominated by rocky $\mathrm{mtn}$. fescue, alpine timothy, sedge.

SACFA7

Site dominated by slender wheatgrass, sedge, fringed brome

12. Heavily grazed site dominated by Kentucky bluegrass and dandelion........SACFA16

Abandoned airstrips dominated by creeping red fescue, or invaded strips dominated by forbs (fireweed, veiny meadow)

SACFA15

13 Site dominated by creeping red fescue.

Moister disturbed site dominated by fireweed and veiny meadow rue...SACFA17

14. Moist sites dominated by sedge and tufted hairgrass.

Drier sites dominated by rough fescue, hairy wildrye, bog sedge, yellow dryas

or California oatgrass......

SACFA4

SACFA5

Site dominated by sedge, tufted hairgrass co-dominant.

SACFA 9

16. Sites dominated by rough fescue and hairy wildrye.

Sites dominated by California oatgrass, bog sedge, or yellow dryas.

17. Gravelly river flats dominated by yellow dryas.

SACMA9

Meadow areas dominated by California oatgrass and/or bog sedge.......

18. Site dominated by bog sedge and california oatgrass.

Site dominated by california oatgrass and sedge, bog sedge not present.........SACFA8

19. Site dominated by bog sedge, california oatgrass, drier sites.........................SACMA1

Site co-dominated by bog sedge, tufted hairgrass, and sedge moister sites... SACFA13

20. Lower elevation grasslands in the Foothills of the Subalpine.

Higher elevation grasslands in the mountains of the Subalpine.

21 Northern wheatgrass dominated site
13

15

12

11

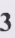

16

17

18

19

21

22 
Fringed sage, sedge and junegrass dominated slope

SACFA12

22. Avalanche slopes dominated by hairy wildrye, juniper, and bearberry....SACMA6

Drier sites or windswept ridges dominated hairy wildrye, juniper, bearberry, shrubby cinquefoil, white mtn. avens..

SACFA14

23. Windswept ridges dominated by white mtn. avens.

South facing slopes dominated by hairy wildrye.

23

24

24. Shallow rocky soils with little grass cover, site dominated by bearberry.. SACMA4

Deeper soils, good grass cover dominated by hairy wildrye, junegrass.

SACMA3

25. Shrubby cinquefoil dominant in stand.

SACMA5

\section{Shrub dominated communities}

1. Timberline communities dominated by whitebark pine, subalpine fir, grouseberry, or willow communities with marsh marigold, wandering daisy or globeflower in understory 2

Riparian communities adjacent to streams or rivers.

2. Trees present in community (whitebark pine, subalpine fir) or grouseberry dominated....

Moist seepage areas at treeline dominated by globeflower, wandering daisy or marsh marigold in understory.

SACMB6

3. Trees (subalpine fir, whitebark pine) on site Grouseberry dominated shrubland...

SACMB7

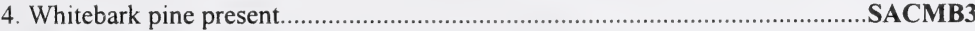
Subalpine fir present..........................................................................SACMB8

5. Very wet sites with water sedge or horsetail dominated understories.

6

Drier sites with tufted hairgrass, california oatgrass, bog sedge, hairy wildrye, rough fescue Kentucky bluegrass, dandelion dominated understories..

6. Water sedge dominated understory.

SACFB1, SACMB1

Horsetail dominated understory.

SACFB2

7. Grazed communities dominated by clover and dandelion in understory.

SACFB5

Ungrazed sites dominated by native forbs and grasses in understory

8

8. Shrubland communities on seepage areas on south facing slopes with shallow soils, dominated by bog birch and juniper.

SACMB5

Meadows and lowland shrublands dominated by rough fescue, bog sedge, california oatgrass, tufted hairgrass, hairy wildrye

or sedge in the understory.

9

9. Rough fescue dominates the understory.

10

11

Tufted hairgrass, california oatgrass, bog sedge, sedge, hairy wildrye dominate.

10. Rough fescue and bog sedge dominate understory higher elevations.

Rough fescue dominates, bog sedge not present lower elevations.

SACFB10

SACFB9

11. Moister sites with deep fluvial deposits dominated by tufted hairgrass, sedge, or fringed brome in understory

Drier sites which are well drained at the surface dominated by hairy wildrye, sedge, bog sedge or california oatgrass in understory.

12. Tufted hairgrass or sedge dominated understory.

Fluvial areas with Fringed brome dominated understory, lower elevation

SACFB11

13. Tufted hairgrass dominates understory

SACFB4

Graceful sedge and other sedge species dominate understory

SACFB3, SASMB2

14. Modal sites with hairy wildrye and sedge dominating understory

Sites dominated by california oatgrass or bog sedge in understory

15. Hairy wildrye dominates understory...... Graceful sedge and other sedge species dominate understory

16. California oatgrass dominates understory. Bog sedge dominates understory.
SACFB6

SACFB8, SACMB4 


\section{SACMA1. Bog sedge-California oatgrass (Kobresia myosuroides-Danthonia californica)}

$\mathbf{n}=\mathbf{1} \quad$ This community type appears to represent the transition from the foothills ecodistricts to the mountain ecodistricts of the subalpine. It appears that tufted hairgrass, california oatgrass and rough fescue all decline and bog sedge increases as there is an increase in elevation and change from the foothills to the mountains.

This community type is found on level to gently sloping valley bottoms with mesic moisture regimes. The presence of California oatgrass maybe indicative of a well drained, gravelly site. In the Yukon the California oatgrass dominated community types were found to form in depressions which appeared to act as pronounced frost pockets (Bailey et al. 1992). Bog sedge also appears to be adapted to these site condition (Oglivie 1969).

\section{Plant COMPOSITION CANOPy COVER(\%) Mean Range CONST.}

SHRUBS

WILLOW

(Salix spp.)

SHRUBBY CINQUEFOIL

(Potentilla fruticosa)

2

100

\section{FORBS}

BEARBERRY

(Arctostaphylos uva-ursi) 15

YARROW

(Achillea millefolium) 1

SMALL LEAVED EVERLASTING

(Antennaria parviflora) 1

\section{GRASSES}

CALIFORNIA OATGRASS

(Danthonia californica) 35

BOG SEDGE

(Kobresia myosuroides) 25

100

100

100

100

\section{ENVIRONMENTAL VARIABLES}

MOISTURE REGIME:

MESIC

\section{NUTRIENT REGIME:}

MESOTROPHIC

ELEVATION:

$1850 \mathrm{M}$

SOIL DRAINAGE:

WELL

Forage Production Kg/HA

\author{
Suggested GraZING CAPACITY \\ NON-USE
}




\section{SACMA2. Forb meadows}

(Trollius albiflorus, Erigeron peregrinus, Anemone occidentalis, Caltha leptosepala)

$\mathbf{n}=17$ These forb dominated meadows include both the Caltha leptosepala-Trollius albiflorus and Erigeron peregrinus-Valeriana sitchensis community types described by Corns and Achuff (1982). These meadows occupy mesic to hygric, gently sloping, upper subalpine to alpine areas. The soils are imperfectly to well drained Gleysols on fluvial and morainal landforms. On the poorly to imperfectly drained sites in areas where snow melts late and seepage is received throughout the growing season mountain marigold and globeflower predominate. In contrast on better drained, drier sites fleabane and mountain heliotrope predominate.

\section{Plant Composition Canopy Cover(\%) MEAN Range Const.}

SHRUBS

ARCTIC WILLOW

(Salix arctica)

$1 \quad 0-5 \quad 59$

WESTERN MOUNTAIN HEATHER

(Cassiope mertensiana) 3

$0-10 \quad 47$

\section{FORBS}

WANDERING DAISY

(Erigeron peregrinus)

WOOLY EVERLASTING

(Antennaria lanata)

GLOBEFLOWER

(Trollius albiflorus)

MOUNTAIN HELIOTROPE

(Valeriana sitchensis)

MOUNTAIN MARIGOLD

(Caltha leptosepala)

CHALICEFLOWER

(Anemone occidentalis)

9

$0-10 \quad 88$

$4 \quad 0-35 \quad 65$

$13 \quad 0-40 \quad 82$

$0-20 \quad 82$

$0-23 \quad 53$

$0-20 \quad 70$

GRASSES

BLACKENING SEDGE

(Carex nigrescens)

MOUNTAIN TIMOTHY

(Phleum commutatum)

SEDGE

(Carex spectabilis)

$0-2 \quad 41$

$0-10 \quad 23$

\section{ENVIRONMENTAL VAR ${ }^{\cdots}$ ES}

MoISTURE REgIME:

MESIC TO HYGRIC

NUTRIENT REGIME:

PERMESOTROPHIC

ELEVATION:

$2024(1850-2300) \mathrm{M}$

SoIl DRAINAGE:

IMPERFECTLY TO WELL

SLOPE:

$$
27(3-55) \%
$$

ASPECT:

VARIABLE

Forage Production Kg/Ha
Suggested GRAZING CAPACITY

NON-USE 


\section{SACMA3. Shrubby cinquefoil/Hairy wildrye}

(Potentilla fruticosa/Elymus innovatus)

$\mathbf{n}=\mathbf{5}$ Corns and Achuff (1982), described this community type on subxeric to xeric, south facing slopes in Banff and Jasper. The soils are rapidly to well drained Regosols on colluvial, eolian and glacial landforms. On more stable sites they felt succession would be to a Lodgepole pine/Juniper/Bearberry community type.

\section{Plant Composition Canopy Cover(\%)} Mean Range Const.

SHRUBS

SHRUBBY CINQUEFOIL.

(Potentilla fruticosa) $\quad 20 \quad 4-40 \quad 100$

BOG BIRCH

$\begin{array}{llll}\text { (Betula glandulosa) } & 2 & 0-5 & 40\end{array}$

\section{FORBS}

BEARBERRY

(Arctostaphylos uva-ursi) 1

WHITE MOUNTAIN AVENS

(Dryas integrifolia) 3

STRAWBERRY

(Fragaria virginiana) 6

ALPINE FORGET-ME-KNOT

(Myosotis alpestris) 5

SWEET-FLOWERED ANDROSACE

(Androsace chamaejasme) 4

WANDERING DAISY

(Erigeron peregrinus) $2 \quad 0-11 \quad 20$

SPOTTED SAXIFRAGE

(Saxifraga bronchialis) $3 \quad 0-13 \quad 20$

GRASSES

HAIRY WILDRYE

(Elymus innovatus) $\quad 3 \quad 0-10 \quad 60$

BLUNT SEDGE

$\begin{array}{llll}\text { (Carex obtusata) } & 1 & 0-4 & 20\end{array}$

NORWAY SEDGE

(Carex norvegica) $\quad 8$
BROAD GLUMED WHEATGRASS

(Agropyron violaceum) 5

$0-40 \quad 20$

$0-25 \quad 20$

\section{ENVIRONMENTAL VARIABLES}

MOISTURE REGIME:

XERIC-SUBXERIC

NUTRIENT REGIME:

SUBMESOTROPHIC

ELEVATION:

$1720(1500-1800) \mathrm{M}$

SOIL DRAINAGE:

RAPIDLY

SLOPE:

$$
28(15-55) \%
$$

ASPECT:

SOUTHERLY

Forage Production Kg/HA

Not AVAILABLE

Suggested GraZing CAPACITY

NON-USE 


\section{SACMA4. Bearberry-Juniper \\ (Arctostaphylos uva-ursi-Juniperus communis)}

$\mathbf{n}=13$ This community type is very similar to the previously describe Shrubby cinquefoil/Hairy wildrye dominated community type. Both community types occupy rapidly drained, steep south facing slopes. This community type is distinguished from the Shrubby cinquefoil community type by the presence of a high cover of bearberry and juniper and a low cover of shrubby cinquefoil. This community type is much drier than the shrubby cinquefoil type and is located on much steeper slopes.

\section{Plant Composition Canopy Cover(\%)}

Mean RANGe CONST.

\section{SHRUBS}

SHRUBBY CINQUEFOIL

\section{(Potentilla fruticosa)}

GROUND JUNIPER

(Juniperus communis)

SMOOTH WILLOW

(Salix glauca)

\section{FORBS}

STRAWBERRY

(Fragaria virginiana)

WHITE CAMUS

(Zigadenus elegans)

MOUNTAIN VALERIAN

(Valeriana sitchensis)

HARE BELL

(Campanula rotundifolia) 1

TWINFLOWER

(Linnaea borealis) $\quad 1 \quad 0-5 \quad 15$

BEARBERRY

(Arctostaphylos uva-ursi) 16

$8-25 \quad 100$

\section{GRASSES}

HAIRY WILDRYE

(Elymus innovatus) $\quad 2 \quad 0-10 \quad 46$

SPIKED TRISETUM

(Trisetum spicatum)

$0-1$

23

SLENDER WHEATGRASS

(Agropyron trachycaulum)

SHEEP FESCUE

(Festuca saximontana)

SEDGE SPP.

(Carex spp.)

$\begin{array}{lll}4 & 0-18 & 77 \\ 9 & 0-25 & 92 \\ 2 & 0-10 & 46\end{array}$

$0-3$

62

46

15

39

15

100

\section{ENVIRONMENTAL VARIABLES}

MOISTURE REGIME:

XERIC-SUBXERIC

NUTRIENT REGIME:

SUBMESOTROPHIC

ELEVATION:

1901(1700-2000) M

SOIL DRAINAGE:

RAPIDLY

SLOPE:

$$
60(55-71) \%
$$

ASPECT:

SOUTHERLY

Forage Production KG/HA

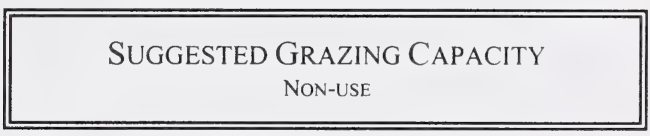




\section{SACMA5. Junegrass-Hairy wildrye-Brome (Koeleria macrantha-Elymus innovatus-Bromus inermis)}

$\mathbf{n}=\mathbf{2 2}$ This community type was described by Corns and Achuff (1982) on subxeric, steep south facing slopes in the Front ranges east of Banff and Jasper. It is very similar to the bearberry and shrubby cinquefoil community types previously described, but this community type has better developed soils (Brunisols) than the Regosolic soils of the other community types.

This community type is also similar to the Pasture sagewort/Junegrass and Junegrass-Plains reed grass community types described by Willoughby et al (2003) and Stringer (1973) in the lower Montane subregion and the Junegrass/Sage community type described in the Upper Foothills subregion (Willoughby 2001). The high elevations of this community distinguishes this community type from the lower elevation grasslands (Corns and Achuff 1982).

\section{Plant Composition Canopy Cover $(\%)$ Mean Range Const.}

\section{SHRUBS}

SHRUBBY CINQUEFOIL

(Potentilla fruticosa) $1 \quad 0-6 \quad 59$

\section{FORBS}

SLENDER BLUE BEARDTONGUE

$\begin{array}{lccc}\begin{array}{l}\text { (Penstemon procerus) } \\ \text { YARROW }\end{array} & \text { T } & 0-2 & 27 \\ \begin{array}{l}\text { (Achillea millefolium) } \\ \text { SHOWY LOCOWEED }\end{array} & 2 & 0-15 & 82 \\ \begin{array}{l}\text { (Oxytropis splendens) } \\ \text { BEARBERRY }\end{array} & 2 & 0-15 & 59 \\ \begin{array}{l}\text { (Arctostaphylos uva-ursi) } 1 \\ \begin{array}{l}\text { YELLOW HEDYSARUM } \\ \text { (Hedysarum sulphurscens)5 }\end{array}\end{array} & 0-10 & 41 \\ \begin{array}{l}\text { SMALL LEAVED EVERLASTING } \\ \text { (Antennaria parviflora) } 3\end{array} & 0-15 & 50 \\ \end{array}$

\section{GRASSES}

ROCKY MOUNTAIN FESCUE

(Festuca saximontana) T

JUNEGRASS

(Koeleria macrantha) $15 \quad 0-35 \quad 96$

HAIRY WILDRYE

(Elymus innovatus) $\quad 17 \quad 0-55 \quad 82$

SEDGE

(Carex spp.) $\quad 1 \quad 0-10 \quad 54$

BROME

(Bromus inermis)

\section{ENVIRONMENTAL VARIABLES}

MoISTURE REgIME:

XERIC-SUBXERIC

NUTRIENT REGIME:

SUBMESOTROPHIC

ELEVATION:

1964(1910-2100) M

SOIL DRAINAGE:

RAPIDLY

SLOPE:

$49(40-56) \%$

ASPECT:

SOUTHERLY

Forage Production Kg/Ha

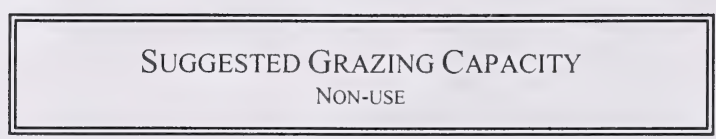




\section{SACMA6. Hairy wildrye/Bearberry-Juniper \\ (Elymus innovatus/Arctostaphylos uva-ursi-Juniperus communis)}

n=36 Ogilvie (1969) and Corns and Achuff (1982), described this community type on steep south-facing slopes, with stoney, black soils. This community type is also subjected to frequent snow avalanching, particularly during the spring when the snow is melting. This community type is moister than the junegrass, bearberry and shrubby cinquefoil communities previously described. This is likely the result of the increased snow cover. The soils are Melanic Brunisols and Humic Regosols, which are better developed than the drier community types previously described.

\section{Plant Composition Canopy Cover(\%)}

Mean RANGe CONST.

SHRUBS

JUNIPER

(Juniperus communis)

SHRUBBY CINQUEFOIL

(Potentilla fruticosa)

6

0-30

63

$3 \quad 0-24 \quad 44$

FORBS

BEARBERRY

(Arctostaphylos uva-ursi) $16 \quad 0-60 \quad 76$

WILD STRAWBERRY

(Fragaria virginiana)

WHITE CAMAS

(Zigadenus elegans) 1

FIREWEED

(Epilobium angustifolium) 1

TWINFLOWER

(Linnaea borealis)

YELLOW HEDYSARUM

(Hedysarum sulphurscens) 3

GRASSES

HAIRY WILDRYE

(Elymus innovatus)

44

JUNEGRASS

(Koeleria macrantha)

CALIFORNIA OATGRASS

(Danthonia californica) 15

RED FESCUE

(Festuca rubra)

SPIKED TRISETUM

(Trisetum spicatum)

$0-25 \quad 39$

0-70 98

$0-5 \quad 28$

$0-40 \quad 13$

$0-30 \quad 2$

$0-5 \quad 28$

\section{ENVIRONMENTAL VARIABLES}

MOISTURE REGIME:

MESIC

NUTRIENT REGIME:

PERMESOTROPHIC

ELEVATION:

1942(1380-2300)M

SOIL DRAINAGE:

WELL

SLOPE:

$52(0-80) \%$

ASPECT:

SOUTH

Forage Production Kg/HA

\section{SUGgESTED GRAZING CAPACITY \\ NON-USE}




\section{SACMA7. Northern wheatgrass \\ (Agropyron dasystachyum)}

$\mathbf{n}=\mathbf{3} \quad$ This community type occurs on steep south facing slopes, with shallow soils, at lower elevations in the subalpine. It is very similar to the northern wheatgrass community type described by Willoughby et al. (2003) and Corns and Achuff (1982) in the Montane subregion of Banff and Jasper. This community type is distinguished from the other hairy wildrye, junegrass, bearberry and shrubby cinquefoil community types by the presence of northern wheatgrass and the lower elevations. The inaccessibility and fragile nature of the soils make this community type unsuitable for grazing.

\section{Plant Composition Canopy Cover $(\%)$ MEAN RANGE CONST.}

SHRUBS

PRICKLY ROSE

(Rosa acicularis)

$1 \quad 0-1 \quad 67$

\section{FORBS}

BEARBERRY

(Arctostaphylos uva-ursi) T

SHOWY LOCOWEED

(Oxytropis splendens) $\quad 1 \quad 0-3 \quad 67$

FIREWEED

(Epilobium angustifolium)2

WESTERN MEADOW RUE

(Thalictrum occidentalis) 6

COMMON YARROW

(Achillea millefolium)

GRASSES

JUNEGRASS

(Koeleria macrantha) $3 \quad 0-5 \quad 67$

ALPINE TIMOTHY

(Phleum commutatum) $\quad 1 \quad 0-2 \quad 67$

BLUNT SEDGE

$\begin{array}{llll}\text { (Carex obtusata) } & 1 & 0-1 & 67\end{array}$

HAIRY WILDRYE

(Elymus innovatus) $\quad 3 \quad 0-10 \quad 33$

NORTHERN WHEATGRASS

(Agropyron dasystachyum) 30
$0-5 \quad 67$

$0-18 \quad 33$

$0-10-33$

$0-15 \quad 67$
1-2 100

\section{ENIIRONMENTAL VARIABLES}

MoISTURE RegIME:

SUBXERIC-XERIC

NUTRIENT REGIME:

SUBMESOTROPHIC

SLOPE:

$$
31(30-60) \%
$$

ASPECT:

SOUTHERLY

ELEVATION:

1720( 1220-1859)M

SOIL DRAINAGE:

RAPIDLY

Forage Production KG/HA

Total $400 *$ Estimate

$0 \mathrm{HA} / A U M$ OR 0 ACRES/AUM 


\section{SACMA8. Alpine bluegrass}

(Poa alpina)

$\mathbf{n}=\mathbf{1}$ The ecology of this community type is unclear. It was described on a gentle, easterly slope in the lower subalpine. Alpine bluegrass is known to grow in meadows, tundra and rocky slopes and is often abundant where the ground has been compacted (MacKinnon et al. 1992). It is possible that this community type could have been described adjacent to a game or hiking trail.

\section{Plant Composition Canopy Cover(\%)}

MEAN RANGe CONST.

\section{SHRUBS}

DWARF BILBERRY

(Vaccinium caespitosum) $6 \quad-\quad 100$

SHRUBBY CINQUEFOIL

$\begin{array}{llll}\text { (Potentilla fruticosa }) \quad 4 \quad-\quad & 0\end{array}$

\section{FORBS}

STRAWBERRY

(Fragaria virginiana) $\quad 20 \quad-\quad 100$

FIREWEED

(Epilobium angustifolium)4 $\quad$ - $\quad 100$

BALSAM GROUNDSEL

(Senecio pauperculus)

$3 \quad-\quad 100$

Grasses

ALPINE BLUEGRASS

(Poa alpina) $\quad 45 \quad-\quad 100$

ROCKY MOUNTAIN FESCUE

(Fescue brachyphylla)

\section{ENVIRONMENTAL VARIABLES}

MOISTURE REGIME:

SUBMESIC

NUTRIENT REGIME:

SUBMESOTROPHIC

ELEVATION:

$1800 \mathrm{M}$

SOIL DRAINAGE:

WELL

SLOPE:

$4 \%$

ASPECT:

EASTERLY

Forage Production KG/HA

NON-USE 


\section{SACMA9. Yellow mountain avens}

\section{(Dryas drummondil)}

$\mathbf{n}=4$ Corns and Achuff (1982), described this community type on recent fluvial and glacialfluvial landforms with gentle slopes. The soils are rapidly drained. Willoughby et al. (2003), described a yellow mountain avens community type on dry, gravelly river flats with nutrient poor soils in the Montane subregion. They found this community type to be successionally immature and succession would be to a Balsam poplar dominated community type.

\section{Plant COMPOSITION CANopy Cover(\%)}

MEAN RANGE CONST.

\section{SHRUBS}

YELLOW MOUNTAIN AVENS

(Dryas drummondii) $\quad 50 \quad 25-50 \quad 100$

WILLOW SPP.

(Salix spp.)

$5 \quad 0-20 \quad 50$

FORBS

ALPINE GOLDENROD

(Solidago multiradiata) T

BROAD LEAVED FIREWEED

(Epilobium latifolium) 1

SHOWY LOCOWEED

(Oxytropis splendens) 1

GRASSES

SEDGE

(Carex spp)

$0-2 \quad 25$

\section{ENVIRONMENTAL VARIABLES}

\section{MOISTURE REGIME:}

SUBXERIC

NUTRIENT REGIME:

MESOTROPHIC

ELEVATION:

$1542(1450-1670) \mathrm{M}$

SOIL DRAINAGE:

RAPIDLY

Forage Production Kg/HA

\section{SUGgESTED GRAZING CAPACITY}

NON-USE 


\section{SACMB1. Willow/Water sedge \\ (Salix spp./Carex aquatilis)}

$\mathbf{n}=\mathbf{2 3}$ This shrub community appears on areas with very poor drainage. It is found in association with the wetter water sedge meadows. These sites are fairly productive but difficult to graze due to the moist ground conditions and heavy shrub cover which reduces access and mobility within the area. Increased flooding and prolonged waterlogging may result in the disappearance of willow and a transition to a water sedge meadow.

This community is similar to the water sedge-beaked sedge community in that it is found throughout the foothills and into the mountains. It maybe found in the Upper Foothills, Subalpine and lower Alpine subregions.

\section{Plant COMPOSITION CANOPY COVER(\%)} Mean Range CONST.

\section{SHRUBS}

WILLOW

(Salix spp)

BOG BIRCH

(Betula glandulosa)

0-75

96

\section{FORBS}

ELEPHANT'S HEAD

(Pedicularis groenlandicum) 1

DWARF RASPBERRY

(Rubus arcticus)

ALPINE BISTORT

(Polygonum viviparum) T

WANDERING DAISY

(Erigeron peregrinus)

$0-7 \quad 30$

$0-4 \quad 30$

$0-1 \quad 17$

$0-3 \quad 22$
GRASSES

WATER SEDGE

(Carex aquatilis)

$50 \quad 15-80 \quad 100$

TUFTED HAIRGRASS

(Deschampsia cespitosa) 3

SEDGE

(Carex spp.)

BALTIC RUSH

(Juncus balticus)
$0-30 \quad 26$

$0-20 \quad 4$

0-1 4

\section{ENVIRONMENTAL VARI_._LES}

MOISTURE REGIME:

SUBHYGRIC-HYGRIC

NUTRIENT REGIME:

PERMESOTROPHIC

ELEVATION:

1747(1340-1970) M

SOIL DRAINAGE:

POORLY

Forage Production KG/Ha

GRASS 2320

FORBS 24

TOTAL 2344

Suggested GraZING CAPACITY

NON-USE 


\section{SACMB2. Willow-Bog birch/Sedge \\ (Salix glauca-Betula glandulosa/Carex spp.)}

$\mathbf{n = 2 1}$ This community type is found in association with the Tufted hairgrass-Sedge or California oatgrass community type. Willow encroachment into grassland meadows eventually results in this community type. Historically fire has played an important role in the maintenance of the grassland community type in this ecoregion. Continued fire suppression will eventually allow willow and bog birch to invade many of the grassy meadows. This community type is slightly drier than the Willow/Water sedge dominated community type.

\section{PLANT COMPOSITION CANOPY}

COVER(\%)

\section{SHRUBS}

SMOOTH WILLOW .

\section{(Salix glauca)}

BARRET'S WILLOW

(Salix barrattiana)

BOG BIRCH

(Betula glandulosa)

\section{Mean Range Const.}

\section{FORBS}

\section{YARROW}

(Achillea millefolium) $1 \quad 0-5$

WILD STRAWBERRY

(Fragaria virginiana) $3 \quad 0-23 \quad 57$

WANDERING DAISY

(Erigeron peregrinus) $\quad 1 \quad 0-8 \quad 38$

MOUNTAIN HELIOTROPE

(Valeriana sitchensis) $\quad$ T $\quad 0-5 \quad 23$

GLOBEFLOWER

$\begin{array}{llll}\text { (Trollius albiflorus) } & 2 & 0-7 & 38\end{array}$

WOOLLY EVERLASTING

(Antennaria lanata) $\quad 1 \quad 0-12 \quad 33$

GRASSES

TUFTED HAIRGRASS

(Deschampsia cespitosa) $1 \quad 0-4 \quad 29$

CALIFORNIA OATGRASS

$\begin{array}{llll}\text { (Danthonia californica) } & 2 & 0-10 & 19\end{array}$

SEDGE

$\begin{array}{llll}\text { (Carex spp.) } & 23 & 0-73 \quad 95\end{array}$

\section{ENVIRONMENTAL VARIABLES}

MOISTURE REGIME:

MESIC -HYGRIC

NutRIENT REgime:

PERMESOTROPHIC

ELEVATION:

1793(1370-2110) M

SOIL DRAINAGE:

MOD. WELL

\section{Forage Production KG/HA}

\section{SUGGESTED GRAZING CAPACITY}

NON-USE 


\section{SACMB3. Willow-Bog birch/Hairy wildrye \\ (Salix glauca-Bog birch/Elymus innovatus)}

$\mathbf{n}=\mathbf{1 7}$ This community is typical of the valley bottoms where the low temperatures prohibit the growth of trees. Corns and Achuff (1982) described a similar community in the Banff and Jasper National Parks. They found this community type occupied coarse stream deposits which had repeated flooding.

Bork (1994) felt this community type developed from the invasion of willow and bog birch onto grasslands in the absence of disturbance in Willmore Wilderness park. Willow cover has increased, shading the growth of grasses and allowing tall-growing forbs, such as fireweed, aster and veiny meadow rue to increase. He felt continued protection from disturbance will allow succession to shrub and eventually tree species. This community is typical of the valley bottoms throughout the subalpine in both the foothills and mountain ecodistricts.

\section{PLANT COMPOSITION CANOPY COVER(\%)}

Mean Range CONST.

TREES

ENGELMANN SPRUCE

(Picea engelmannii)

T

$0-1$

18

\section{SHRUBS}

WILLOW SPP.
(Salix glauca)

BOG BIRCH

(Betula glandulosa)

SHRUBBY CINQUEFOIL

(Potentilla fruticosa)

FORBS

NORTHERN VALERIAN

(Valeriana dioica)

YARROW

(Achillea millefolium)

FIREWEED

(Epilobium angustifolium) 3

STRAWBERRY

(Fragaria virginiana) 5

TALL LARKSPUR

(Delphinium glaucum)

VEINY MEADOW RUE

(Thalictrum venulosum)

0-85 36

$17 \quad 0-65 \quad 59$

$2 \quad 0-12 \quad 47$

$\mathrm{T}$

0-1 12

$0-4 \quad 71$

$0-20 \quad 59$

$0-20 \quad 82$

$0-10 \quad 65$

0-2 6

GRASSES

BOG SEDGE

(Kobriesia myosuroides) $1 \quad 0-13 \quad 12$

HAIRY WILDRYE

(Elymus innovatus)

17

SEDGE

(Carex spp)
TUFTED HAIR GRASS

\section{ENVIRONMENTAL VARIABLES}

\section{MOISTURE REGIME:}

SUBHYGRIC

NUTRIENT REGIME: MESOTROPHIC

ELEVATION:

$1859(1400-2240) \mathrm{M}$

SOIL DRAINAGE:

WELL TO MODERATELY WELL

Forage Production KG/HA

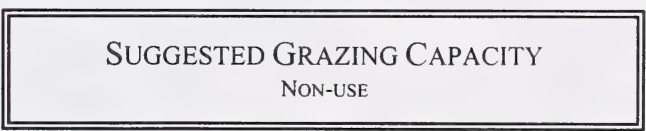




\section{SACMB4. Willow-Bog birch/Bog sedge \\ (Salix spp.-Betula glandulosa/Kobresia myosuroides)}

$\mathbf{n = 1 4}$ This community type was described on moist lowland sites at higher elevations in the Central and Northern Rocky Mountain ecodistricts. It appears this community type originated from recent shrub encroachment onto sedge-bog sedge-tufted hairgrass community type. The presence of bog sedge may represent the transition between the foothills ecodistricts and the rocky mountain ecodistricts. Corns and Achuff (1982) described bog sedge dominated community types in the Central and Northern Rocky Mtn. ecodistricts of the Subalpine subregion of Banff and Jasper National Parks.

\section{Plant Composition CANopy Cover(\%)}

SHRUBS Mean Range Const.

WILLOW SPP.

(Salix spp.) $\quad 24 \quad 0-55 \quad 93$

BOG BIRCH

(Betula glandulosa) $\quad 15 \quad 0-55 \quad 71$

SHRUBBY CINQUEFOIL

(Potentilla fruticosa)

7

$0-20$

79

FORBS

ALPINE BISTORT

(Polygonum viviparum) $1 \quad 0-5 \quad 64$

BEARBERRY

(Arctostaphylos uva-ursi) 3

SMOOTH LEAVED CINQUEFOIL

(Potentilla diversitolia) 1

ALPINE HEDYSARUM

(Hedysarum alpinum) $\quad 3 \quad 0-15 \quad 71$

STRAWBERRY

(Fragaria virginiana) $3 \quad 0-15 \quad 71$

Grasses

BOG SEDGE

(Kobresia myosuroides) $\quad 26 \quad 7-45 \quad 100$

SEDGE

$\begin{array}{llll}\text { (Carex spp.) } & 3 & 0-4 & 71\end{array}$

TUFTED HAIRGRASS

(Deschampsia cespitosum) $2 \quad 0-10 \quad 29$

CALIFORNIA OATGRASS

(Danthonia californica) $\quad 2 \quad 0-10 \quad 21$

\section{ENVIRONMENTAL VARIABLES}

MOISTURE REGIME:

MESIC-SUBHYGRIC

NUTRIENT REGIME:

MESOTROPHIC

ELEVATION:

1901(1700-2280) M

SOIL DRAINAGE:

MODERATELY WELL

Forage Production KG/HA

\section{SUGGESTED GRAZING CAPACITY}

NON-USE 


\section{SACMB5. Bog birch/Juniper \\ (Betula glandulosa/Juniperus communis)}

$\mathbf{n}=\mathbf{6}$ This community type is found on rocky exposures with westerly aspects in association with Engelmann spruce and lodgepole pine forests. The soils are very shallow and rapidly drained.

\section{Plant Composition Canopy Cover(\%)} MEAN RANGe CONST.

\section{SHRLBBS}

BOG BIRCH

(Betula glandulosa) $\quad 38 \quad 0-65 \quad 83$

WILLOW SPP.

(Salix spp.)

$7 \quad 0-4 \quad 50$

\section{FORBS}

YARROW

(Achillea millefolium) $\quad 1 \quad 0-2$

FIREWEED

(Epilobium angustifolium)2 1-2 100

TALL LARKSPUR

(Delphinium glaucum) T $\quad 0-1 \quad 17$

ALPINE GOLDENROD

$\begin{array}{llll}\text { (Solidago multiradiata) } & \mathrm{T} & 0-1 & 17\end{array}$

TWINFLOWER

(Linnaea borealis)

$1 \quad 0-3 \quad 33$

GRASSES

ROCKY MOUNTAIN FESCUE

(Festuca brachyphylla) T

SEDGE

(Carex spp.)

HAIRY WILDRYE

(Elymus innovatus)

$0-3 \quad 80$

$0-15 \quad 50$

\section{ENVIRONMENTAL VARIABLES}

MOISTURE REgIME:

SUBXERIC

NUTRIENT REGIME:

MESOTROPHIC

ELEVATION:

1998(1900-2130) M

SoIl DRAINAGE:

RAPIDLY

SLOPE:

$35(10-50) \%$

ASPECT:

WESTERLY

Forage Production KG/HA
SugGESTED GRAZING CAPACITY

NON-USE 


\section{SACMB6. Willow/Forb \\ (Salix spp./Trollius albiflorus, Erigeron peregrinus, Mountain heliotrope)}

$\mathbf{n}=\mathbf{6}$ This community type results from the invasion of willow onto the forb dominated meadows (SACMA2) previously described. These meadows occupy mesic to subhygric, gently sloping, upper subalpine to alpine areas. The soils are imperfectly to well drained Gleysols on fluvial and morainal landforms (Corns and Achuff 1982). On the poorly to imperfectly drained sites in areas where snow melts late and seepage is received throughout the growing season mountain marigold and globeflower predominate. In contrast on better drained, drier sites wandering daisy and mountain heliotrope predominate.

\section{Plant Composition Canopy Cover(\%)} MEAN RANGe CONST.

SHRUBS

BARRET'S WILLOW .

(Salix barrattiana)

SMOOTH WILLOW

(Salix glauca)

BOG BIRCH

(Betula glandulosa)

$10-75 \quad 100$

$17 \quad 0-40$

2

0-5

33

\section{FORBS}

GLOBEFLOWER

(Trollius albiflorus)

WANDERING DAISY

(Erigeron peregrinus)

MOUNTAIN SAGE

(Artemisia norvegica) $6 \quad 0-15 \quad 50$

MOUNTAIN HELIOTROPE

(Valeriana sitchensis) 4

SMOOTH LEAVED CINQUEFOIL

(Potentilla diversifolia) 4

MOUNTAIN MARIGOLD

(Caltha leptosepala) 2

$2 \quad 0-2 \quad 33$

\section{Grasses}

ALPINE TIMOTHY

(Phleum commutatum) $\quad 1 \quad 0-1 \quad 67$

SEDGE

(Carex spp.) $\quad 10 \quad 0-50 \quad 83$

SIMPLE BOG SEDGE

(Kobresia simpliciuscula) 13

$0-80$

\section{ENVIRONMENTAL VARIABLES}

MOISTURE REGIME:

MESIC

NUTRIENT REGIME:

PERMESOTROPHIC

ELEVATION:

2103(1960-2320) M

SOIL DRAINAGE:

IMPERFECTLY

Forage Production Kg/HA

$0-15 \quad 50$

$0-10 \quad 50$

33

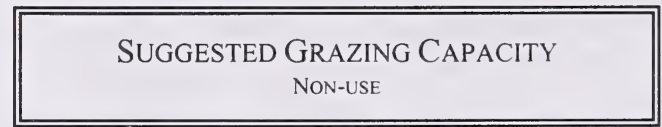




\section{SACMB7. Grouseberry-Juniper \\ (Vaccinium scoparium-Juniperus communis)}

$\mathrm{n}=4$ This is a timberline community type found in conjunction with small patches of subalpine fir. Ogilvie (1969) described a heath-grouseberry community occurring among tree islands and krummholz colonies, on lee slopes with very deep snow accumulation.

\section{Plant COMPOSITION CANOPY COVER(\%)} Mean Range Const.

TREES

SUBALPINE FIR

(Abies lasiocarpa)

$1 \quad 0-4 \quad 25$

\section{SHRUBS}

SMOOTH WILLOW

(Salix glauca)

GROUSEBERRY

(Vaccinium scoparium) $\quad 14 \quad 7-20 \quad 100$

GROUND JUNIPER

(Juniperus communis) $\quad 5 \quad 0-12 \quad 100$

CROWBERRY

(Emptrum nigrum)

$2 \quad 0-8 \quad 25$

\section{FORBS}

FIREWEED

(Epilobium angustifolium) 12

SMALL LEAVED EVERLASTING

(Antennaria parviflora) 3

STRAWBERRY

(Fragaria virginiana) $3 \quad 1-5 \quad 100$

YARROW

(Achillea millefolium) $2 \quad 0-2 \quad 100$

\section{GRASSES}

SPIKED TRISETUM

$\begin{array}{llll}\text { (Trisetum spicatum) } & 7 & 1-20 & 100\end{array}$

SEDGE

(Carex spp.)

CALIFORNIA OATGRASS

(Danthonia californica) 6

$1-8 \quad 100$

100

$0-3 \quad 75$

$0-15 \quad 50$

\section{ENVIRONMENTAL VARIABLES}

MOISTURE REGIME:

SUBXERIC-MESIC

NUTRIENT REGIME:

MESOTROPHIC

ELEVATION:

2157(2080-2260) M

SOIL DRAINAGE:

WELL

Forage Production Kg/HA

\section{SUGGESTED GRAZING CAPACITY} NON-USE 


\section{SACMB8. Subalpine fir \\ (Abies lasiocarpa)}

$\mathbf{n}=\mathbf{2 2}$ This is a timberline community type found in conjunction with small patches of the grouseberry-juniper community type. The trees tend to be very small and shrub like. Ogilvie (1969) described timberline as a gradual breaking -up of the forest into groves, tree islands, low stunted krummholz colonies, and finally dwarfed isolated trees. Ogilvie found timberline to occur high on lee slopes and low on wind-exposed slopes, south facing slopes, avalanche slopes, along stream bottoms and on unstable substrata such as scree and rubble. The major environmental factors controlling timberline are low temperature, wind dessication, avalanching and snow depth.

Plant COMPOSITION CANOPY COVER(\%) MEAN RANGe CONST.

TREES

SUBALPINE FIR

(Abies lasiocarpa)

29

$0-20$

39

SHRUBS

SMOOTH WILLOW

(Salix glauca)

GROUSEBERRY

(Vaccinium scoparium) $4 \quad 0-15 \quad 22$

WHITE FLOWERED RHODODENDRON

$\begin{array}{llll}\begin{array}{l}\text { (Rhododendron albiflorum) } 4 \\ \text { GROUND JUNIPER }\end{array} & 0-30 & 22 \\ \begin{array}{l}\text { (Juniperus communis) } \\ \text { (Jun }\end{array} & 0-15 & 44\end{array}$

FORBS

FIREWEED

$\begin{array}{lll}\text { (Epilobium angustifolium) } 2 & 0-10 \quad 61 \\ \text { MOUNTAIN SAGE }\end{array}$

(Artemisia norvegica) $\quad 3 \quad 0-10 \quad 61$

STRAWBERRY

$\begin{array}{llll}\text { (Fragaria virginiana) } & 1 & 0-5 & 48\end{array}$

WANDERING DAISY

(Erigeron peregrinus) $\quad 2 \quad 0-13 \quad 52$

\section{GRASSES}

SPIKED TRISETUM

$\begin{array}{llll}\text { (Trisetum spicatum) } & \mathrm{T} & 0-5 & 22\end{array}$

SEDGE

(Carex spp.)

HAIRY WILDRYE

(Elymus innovatus)

\section{ENVIRONMENTAL VARIABLES}

MOISTURE REGIME:

MESIC

NUTRIENT REGIME:

MESOTROPHIC

ELEVATION:

1945(1610-2340) M

SOIL DRAINAGE:

WELL

FORAGE PRODUCTION KG/HA

\section{SUGGESTED GRAZING CAPACITY \\ NON-USE}




\section{SUBALPINE SUBREGION}

\section{SOUTHERN ROCKY MOUNTAINS}

\section{NATIVE GRASSLANDS AND SHRUBLANDS}

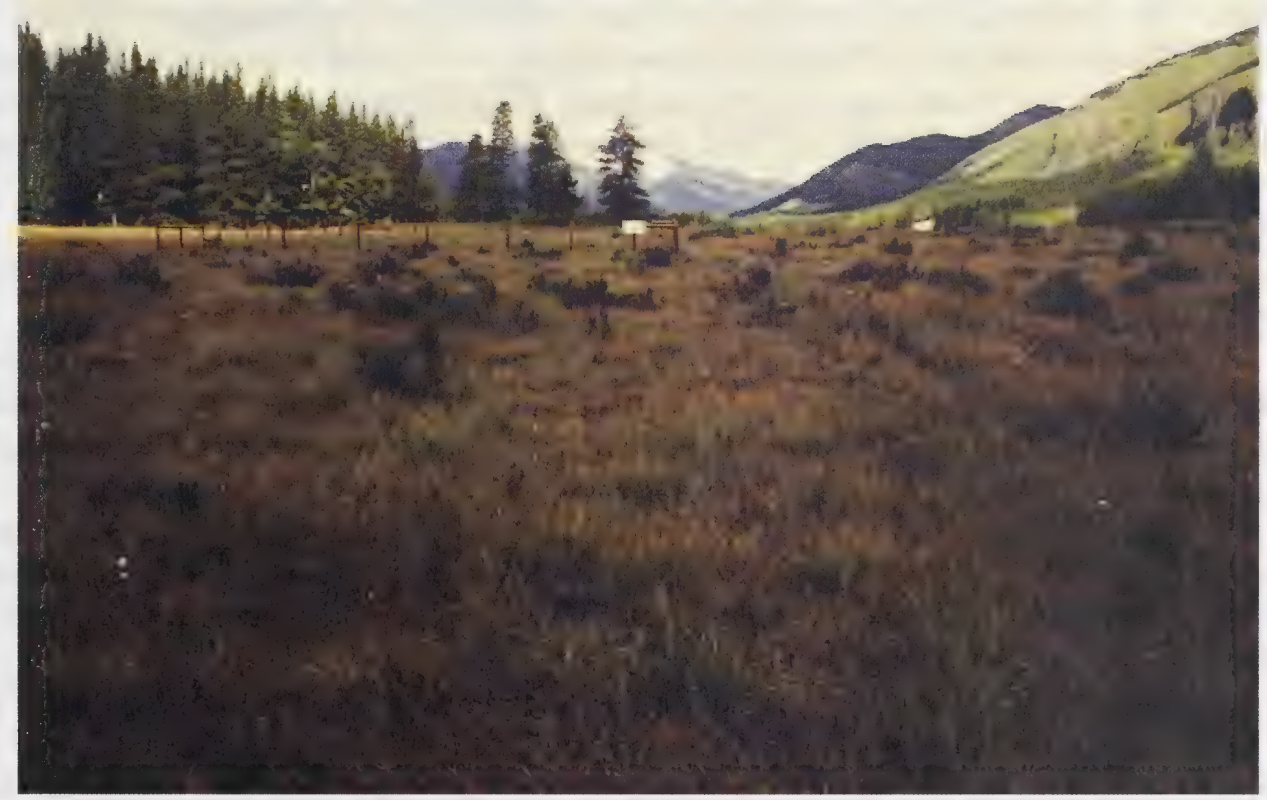

Figure 5. This figure is typical of Rough fescue-Sedge community on mesic sites in the Southern Rocky Mountains of the Subalpine subregion. On steeper slopes rough fescue and hairy wildrye predominate. 


\section{Native grass and shrubland ecology of the Southern Rocky Mountains}

The ecosites and ecosite phases of the native grass and shrubland community types in the Southern Rocky Mountains of the Subalpine subregion (Table 4) are found in the valley bottoms adjacent to streams and rivers and on south facing slopes. This also includes an area that was classified as Lower Foothills, west of Turner Valley. The grass and shrublands within this area more closely resemble the subalpine than the Lower Foothills.

The grassland and shrubland community types in this ecodistrict are strongly influenced by the lower Montane subregion. Many of the grass species associated with the Montane (rough fescue, Parry oatgrass, Idaho fescue) are associated with the grassland community types described in this ecodistrict. On the wet, imperfectly drained lower slope positions the grass and shrubland communities are very similar to the water sedge and willow/water sedge communities described in the northern ecodistricts. It is the grasslands of the south facing slopu urat are different between the southern and northern ecodistricts. In the northern ecodistricts the grasslands of south facing slopes are dominated by hairy wildrye, junegrass and shrubby cinquefoil. In contrast, the grasslands of the southern ecodistrict are dominated by rough fescue, bearberry, hairy wildrye and sedge species.

On gentler south-facing slopes at lower elevations rough fescue and sedge dominate the grassland community types. On more mesic sites within this community Richardson needlegrass may become co-dominant with rough fescue. In contrast at higher elevations on steeper slopes hairy wildrye replaces sedge and Richardson needlegrass as the co-dominant species.

At higher elevations just north of Waterton Lakes National Park the windswept ridges are dominated by Idaho fescue-Junegrass, Bearberry and White mountain avens to form the FescueJunegrass/Bearberry and White mountain avens community types. These community types are important wintering areas for bighorn sheep.

Many of these subalpine grass and shrublands are very fragile because of exposure and cold climate. The forage productivity is generally only half of what is found in the lower Montane subregion and recovery from overgrazing will likely take some time because of the poor growing conditions. Grazing pressure causes rough fescue to decline and allows sedge and hairy wildrye to dominate the community. On moist sites heavy grazing pressure allows Kentucky bluegrass to invade.

The carrying capacity, moisture and nutrient regime of the grass and shrubland communities found in the Southern Rocky Mountains of the Subalpine subregion are outlined in Table 5 . 


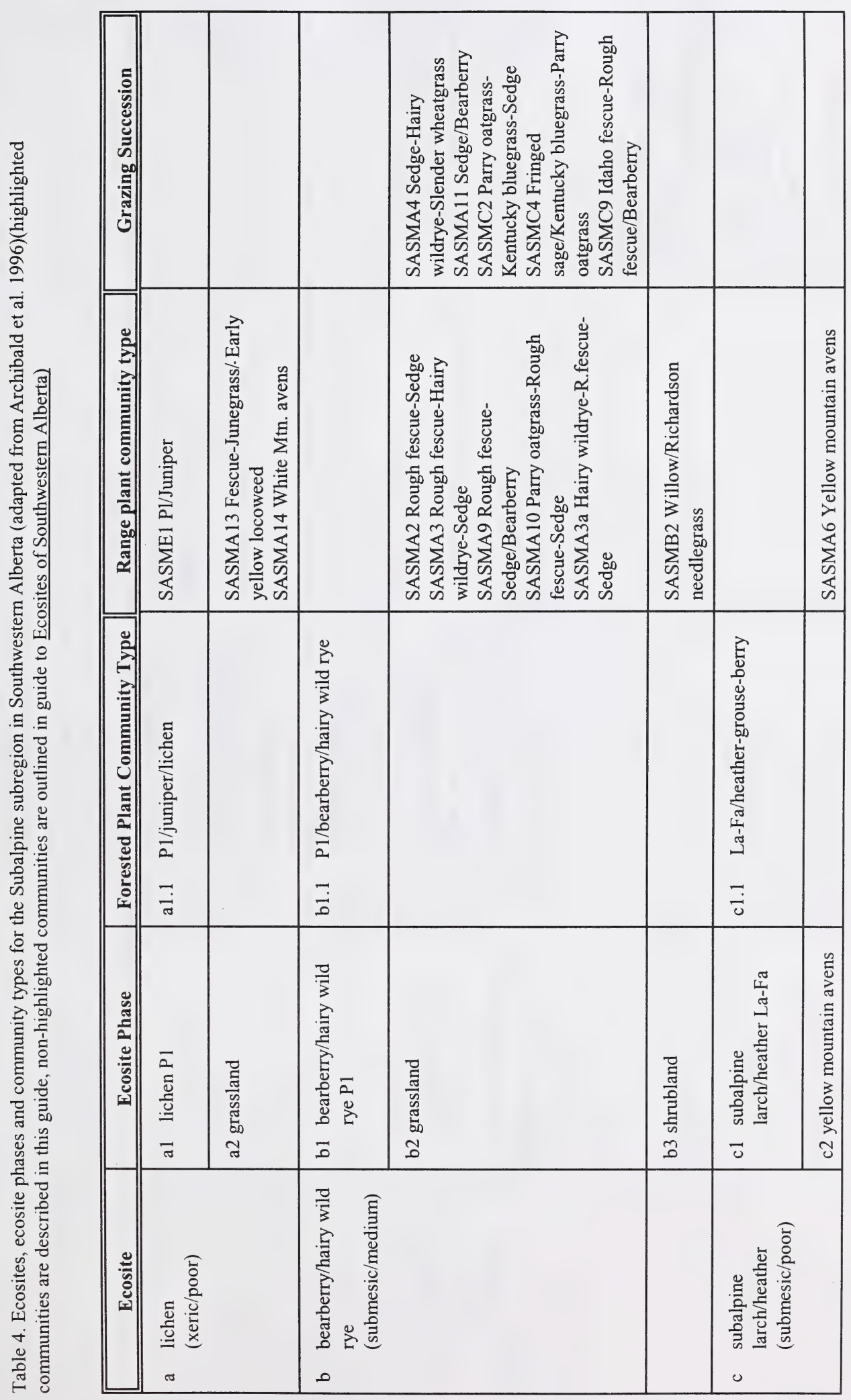




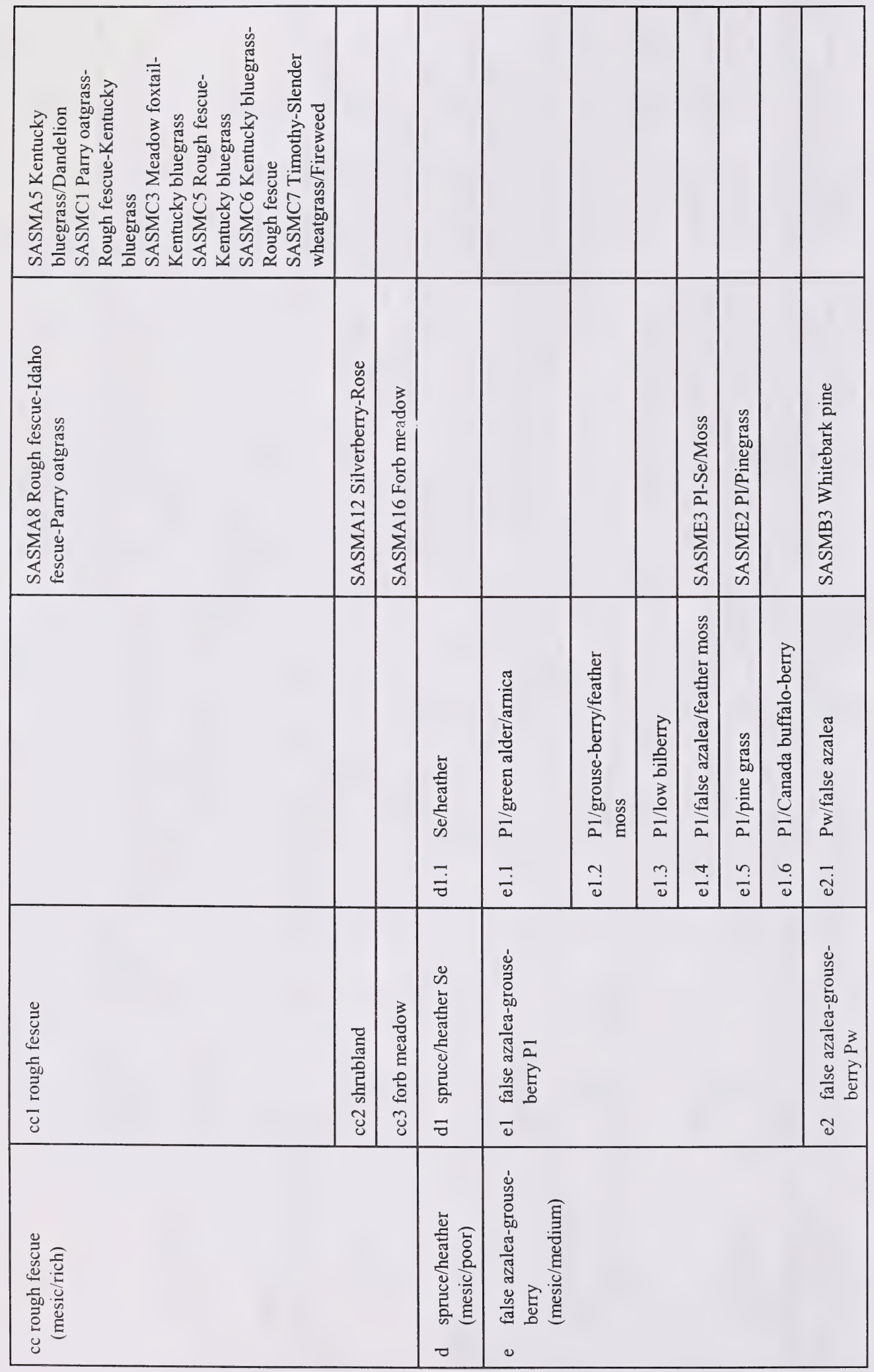




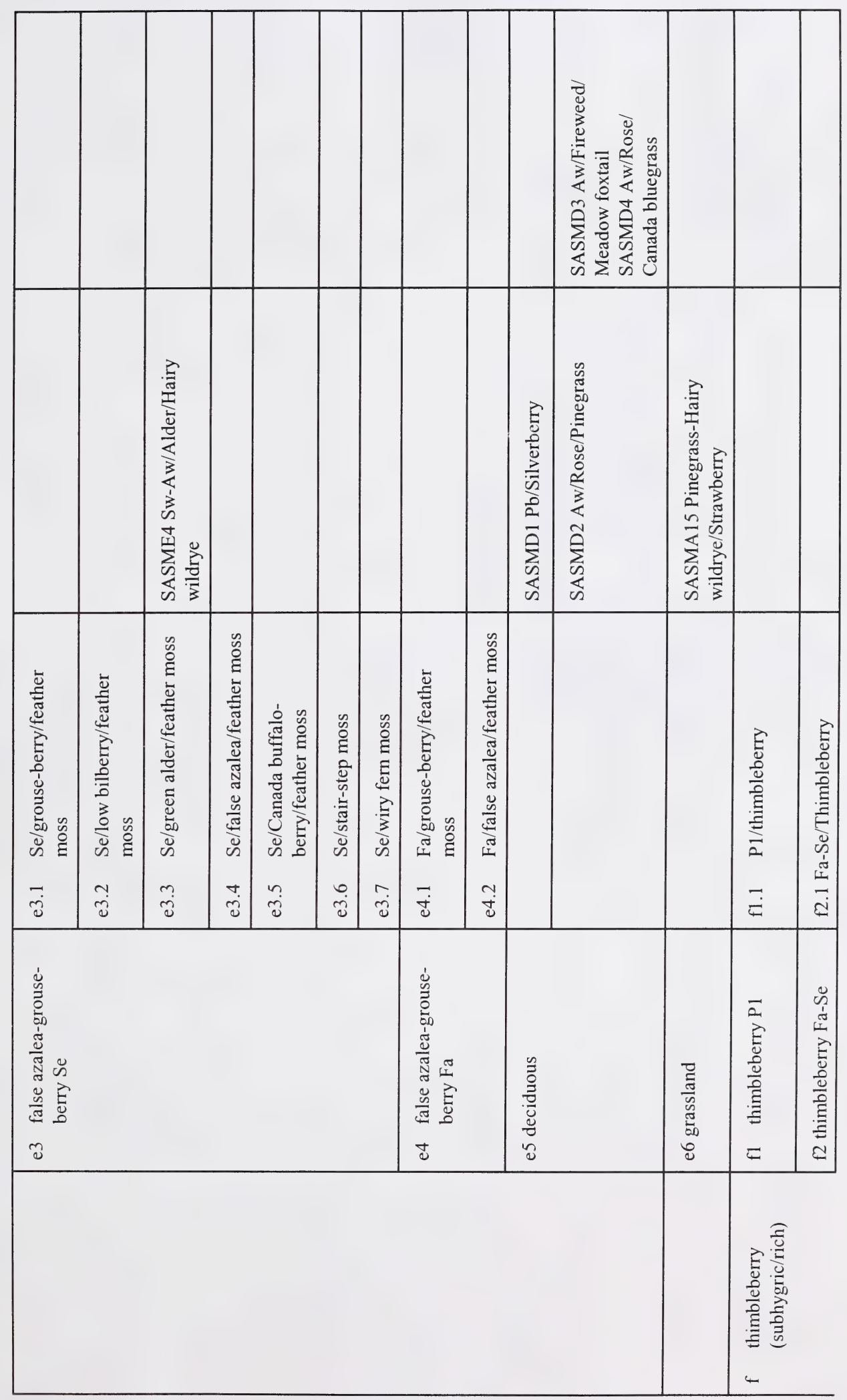




\begin{tabular}{|c|c|c|c|c|c|c|}
\hline 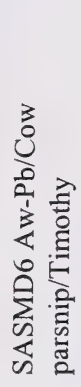 & 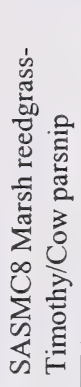 & 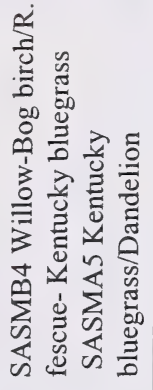 & & & & \\
\hline \multirow[t]{2}{*}{ 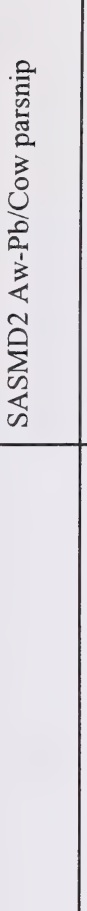 } & 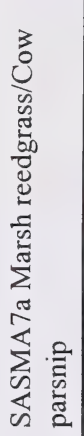 & 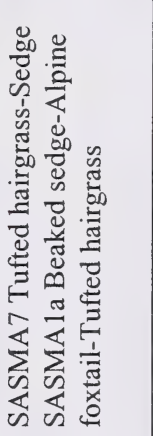 & & & 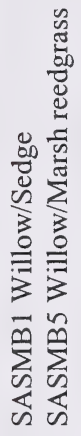 & 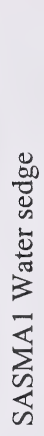 \\
\hline & & 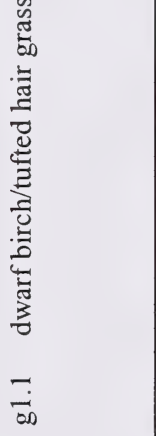 & 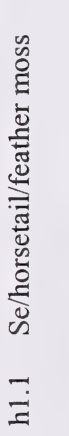 & 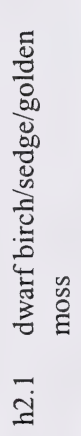 & & \\
\hline \multirow[t]{2}{*}{ 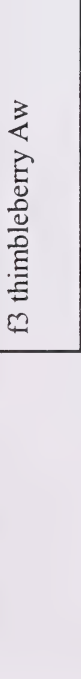 } & 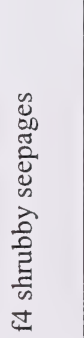 & 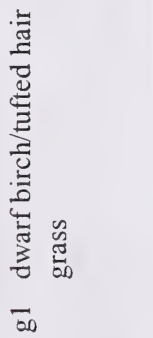 & 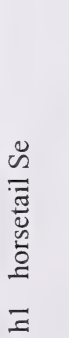 & 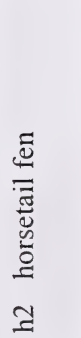 & 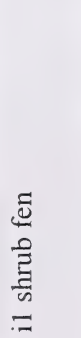 & 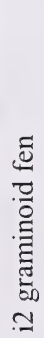 \\
\hline & & 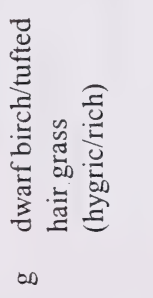 & \multicolumn{2}{|c|}{ 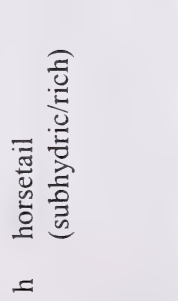 } & \multicolumn{2}{|l|}{ 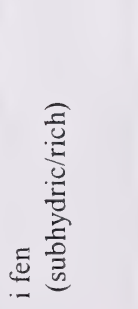 } \\
\hline
\end{tabular}




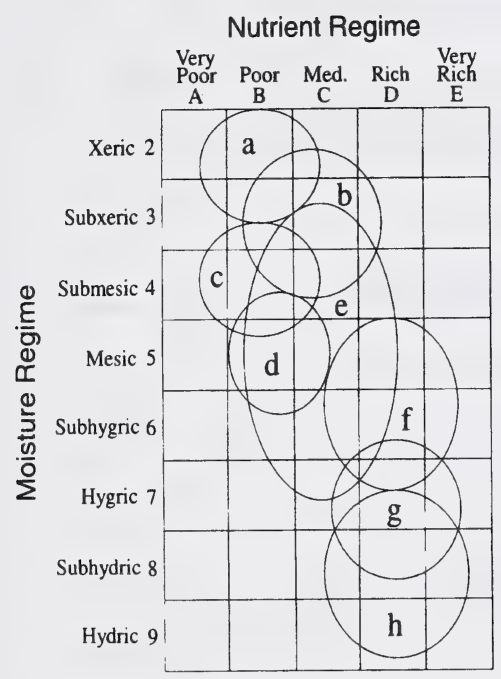

\section{CHARACTERISTIC SPECIES}

Shrubs

[2] Shrubby cinquefoil

\section{Forbs}

[15] White mtn. avens

[1] Bearberry

[1] False dandelion

[2] Spotted saxifrage

[1] Sandwort

[1] Kittentail

[2] Early yellow locoweed

\section{Graminoids}

[3] Sedge

[1] Junegrass

[3] Idaho fescue

[1] Rough fescue
Moisture regime: subxeric, submesic

Nutrient regime: poor, very poor

Topographic position: upper slope, crest

Slope: (6-40)

Aspect: variable

\section{SOIL CHARACTERISTICS}

Organic thickness: (0-2)

Humus form: not available

Surface texture: SL,S,L

Effective texture: SL,LS

Depth to Mottles/Gley: none

Drainage: rapid, well

Parent material: $\mathrm{M}, \mathrm{C} / \mathrm{X}$

Soil subgroup:, O.R, non-soil

\section{COMMUNITY TYPES}

SASMA13 Fescue-Junegrass/Early yellow locoweed( $\mathrm{n}=17)$

SASMA14 White $\mathrm{mtn}$. avens $(\mathrm{n}=12)$ 


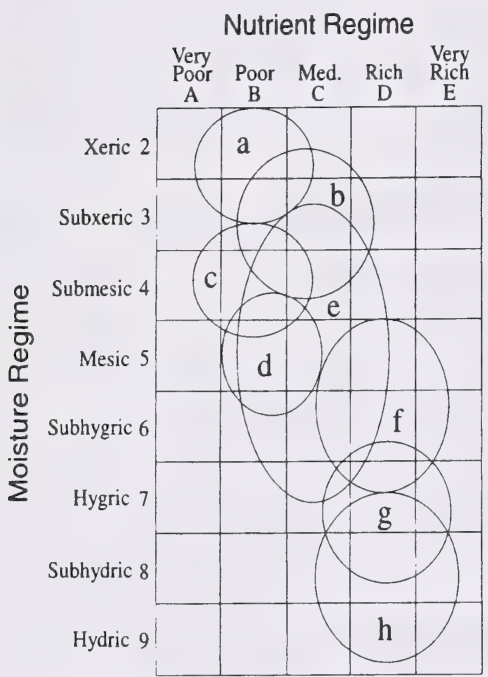

\section{CHARACTERISTIC SPECIES}

\section{Shrubs}

[8] Shrubby cinquefoil

\section{Forbs}

[4] Yellow beardtongue

[ 17 ]Bearberry

[2] Yellow hedysarum

[2] Brown bracted everlasting

[2] Yarrow

[1] Kittentail

[2] Strawberry

Graminoids
[9] Sedge
[1] Junegrass
[2] Idaho fescue
[ 20 ]Rough fescue
[9] Parry oatgrass
[2] Richardson needlegrass

\section{SITE CHARACTERISTICS}

Moisture regime: subxeric, submesic, mesic Nutrient regime: medium

Topographic position: upper slope, crest

Slope: $(0-50)$

Aspect: south, west

\section{SOIL CHARACTERISTICS}

Organic thickness: $(0-2)(2-10)$

Humus form: mull

Surface texture: SL, LS

Effective texture: SL,LS

Depth to Mottles/Gley: none

Drainage: rapid, well

Parent material: $\mathrm{M}, \mathrm{C}, \mathrm{GF}$

Soil subgroup:, O.R, O.EB, O.MB

\section{COMMUNITY TYPES}

SASMA2 Rough fescue-Sedge( $\mathrm{n}=23)$

SASMA3 Rough fescue-Hairy wildrye-Sedge $(n=9)$

SASMA3a Hairy wildrye-Rough fescue-Sedge $(n=1)$

SASMA9 Rough fescue-Sedge/Bearberry $(n=7)$

SASMA10 Parry oatgrass-Rough fescue-

Sedge $(n=12)$ 


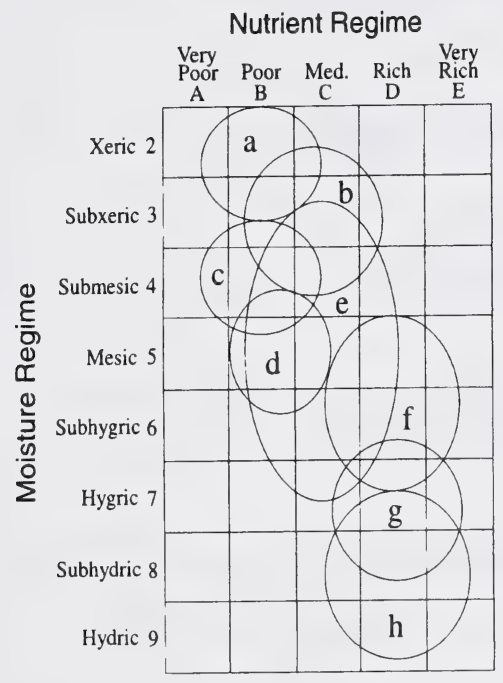

\section{CHARACTERISTIC SPECIES}

Shrubs
[4] Shrubby cinquefoil
[1] Saskatoon
[1] Juniper

\section{Forbs}

[6] Old man's whiskers

[8] Bearberry

[2] Yellow hedysarum

[1] Brown bracted everlasting

[4] Yarrow

[1] Sandwort

[2] Strawberry

\section{Graminoids}

[9] Sedge

[1] Junegrass

[2] Idaho fescue

[5] Rough fescue

[4] Parry oatgrass

[3] Kentucky bluegrass

[1] Timothy

\section{SITE CHARACTERISTICS}

Moisture regime: subxeric, submesic, mesic

Nutrient regime: medium

Topographic position: upper slope, crest

Slope: (0-50)

Aspect: south, west

\section{SOIL CHARACTERISTICS}

Organic thickness: $(0-2)(2-10)$

Humus form: mull

Surface texture: SL, LS

Effective texture: SL,LS

Depth to Mottles/Gley: none

Drainage: rapid, well

Parent material: M,C, GF

Soil subgroup:, O.R, O.EB, O.MB

\section{COMMUNITY TYPES}

SASMA4 Sedge-Hairy wildrye-Slender wheatgrass $(\mathrm{n}=15)$

SASMA11 Sedge/Bearberry $(n=11)$

SASMC2 Parry oatgrass-Kentucky bluegrass-

Sedge $(n=4)$

SASMC4 Fringed sage/Kentucky bluegrass-Parry oatgrass $(\mathrm{n}=1)$

SASMC9 Idaho fescue-Rough fescue/Bearberry $(\mathrm{n}=2)$ 


\section{CHARACTERISTIC SPECIES}

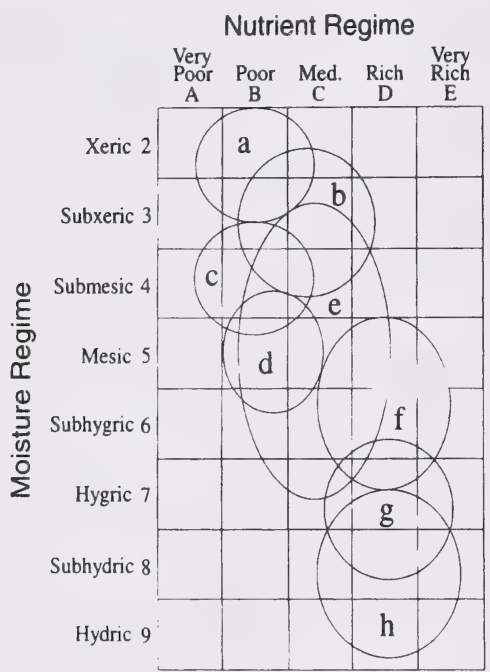

Moisture regime: submesic, mesic Nutrient regime: medium

Topographic position: lower slope Slope: (0-5)

Aspect: south, west

\section{SOIL CHARACTERISTICS}

Organic thickness: $(0-2)(2-10)$

Humus form: mull

Surface texture: SL, LS

Effective texture: SL, LS

Depth to Mottles/Gley: none

Drainage: well

Parent material: F, GF, C

Soil subgroup:, O.R, O.EB

\section{COMMUNITY TYPES}

SASMB2 Willow/Richardson needlegrass $(n=2)$

Shrubs

[30] Willow

[5] Bog birch

[5] Shrubby cinquefoil

Forbs

[1] Northern valerian

[1] Yarrow

[1] Fireweed

[2] Strawberry

Graminoids

[3] Sedge

[8] Rocky mtn. fescue

[45] Richardson needlegrass

[1] Slender wheatgrass 


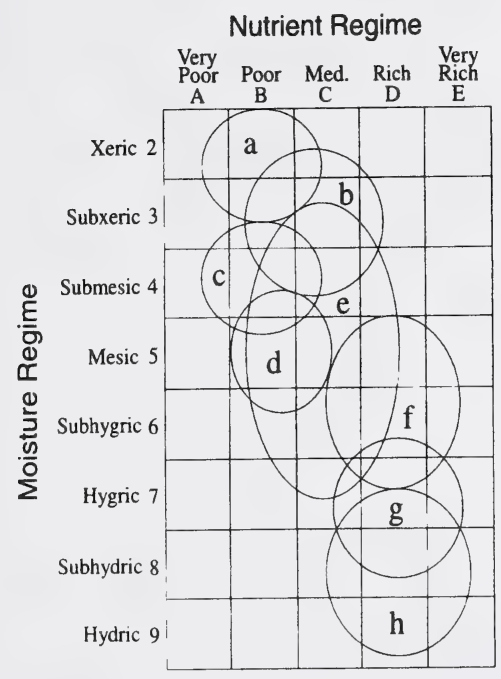

\section{SITE CHARACTERISTICS}

Moisture regime: subxeric, submesic

Nutrient regime: poor, medium

Topographic position: floodplain

Slope: (0-5)

Aspect: variable

\section{SOIL CHARACTERISTICS}

Organic thickness: $(0-2)$

Humus form: mor

Surface texture: SL,SiL

Effective texture: SL,

Depth to Mottles/Gley: none

Drainage: rapid, well

Parent material: F,GF

Soil subgroup:, O.R

\section{COMMUNITY TYPES}

SASMA6 Yellow mtn. avens $(\mathrm{n}=1)$

\section{CHARACTERISTIC SPECIES}

\section{Shrubs}

[4] Shrubby cinquefoil

\section{Forbs}

[13] Yellow mtn. avens

[5] Late yellow locoweed

[3] Silvery cinquefoil

[3] Low goldenrod

[3] Yellow hedysarum

\section{Graminoids}

[67] Sedge

[6] Hairy wildrye

[5] Fringed brome

[1] Slender wheatgrass 


\section{GENERAL DESCRIPTION}

This ecosite is typical of south and west facing slopes and lower slope positions throughout the southern mountains of the Subalpine subregion from an elevation of $1500 \mathrm{~m}$ to $1900 \mathrm{~m}$. This ecosite is usually dominated by grass species because of the dry site conditions and westerly winds. The soils of this ecosite are dominated by deep black soils. A number of rough fescue dominated sites have not had the species composition change in over 30 years of no disturbance in the Montane subregion indicating the climax nature of this ecosite.

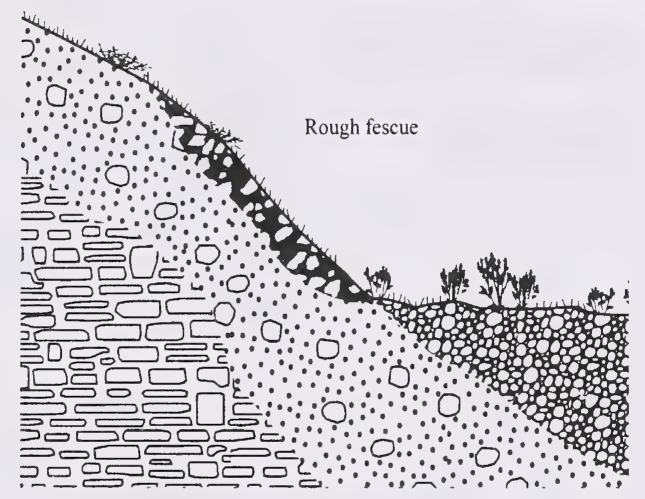

\section{SUCCESSIONAL RELATIONSHIPS}

Due to the nature of the site grasslands often remain the climax vegetation on these sites. On moister sites shrubs and trees such as saskatoon, snowberry, chokecherry and aspen often invade the site. Heavy grazing pressure on these grasslands can often lead to a degraded site that is dominated by Kentucky bluegrass, timothy and clover species.

\section{INDICATOR SPECIES}

rough fescue

Parry oatgrass

Idaho fescue

Kentucky bluegrass

Timothy

Dandelion

Old man's whiskers

Silverberry

\section{mesic/rich}

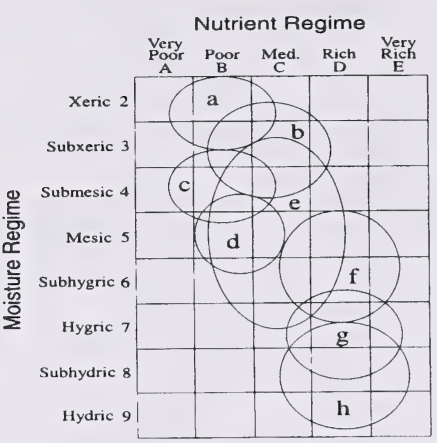

\section{SITE CHARACTERISTICS}

Moisture regime: submesic, mesic

Nutrient regime: rich, medium

Topographic position: crest, midslope, lower slope Slope: $(0-2 \%)^{5}(16-30 \%)^{3}(31-45 \%)^{1}(45-70 \%)^{1}$

Aspect: south, southwest, west

\section{SOIL CHARACTERISTICS}

Organic thickness: $(0-2)(2-5)$

Humus form: mull

Surface texture: CL, SiL, L

Effective texture: CL, SiL, SL,

Depth to Mottles/Gley: none

Drainage: well

Parent material: F, GF, M

Soil subgroup: O.BL, O.DG, O.MB

\section{ECOSITE PHASES}

ccl rough fescue $(n=4)$

$\mathrm{ccla}$ grazed rough fescue $(\mathrm{n}=46)$

cc2 shrubland( $\mathrm{n}=1)$ 


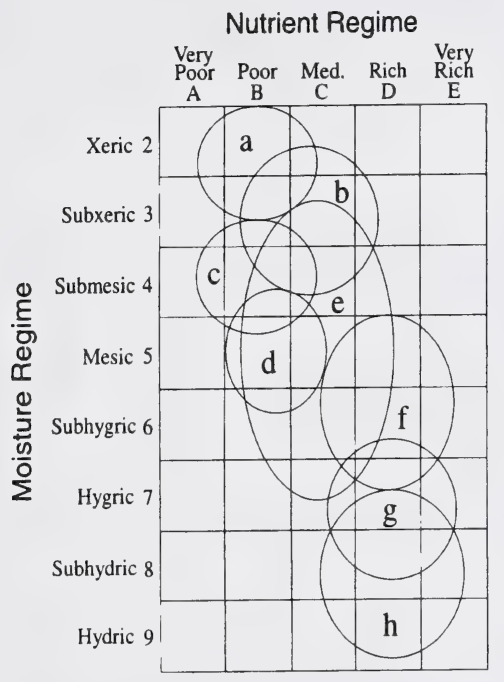

\section{CHARACTERISTIC SPECIES}

\section{Shrubs}

[6] Shrubby cinquefoil

[4] Rose

[3] Saskatoon

\section{Forbs}

[ 15 ] Showy aster

[ 10 ] Strawberry

[ 7 ] Sticky purple geranium

[1] White mtn. avens

[3] Northern bedstraw

\section{Graminoids}

[ 23 ]Rough fescue

[ 10 ]Idaho fescue

[4] Parry oatgrass

[3] Sedge

\section{SITE CHARACTERISTICS}

Moisture regime: submesic, mesic

Nutrient regime: rich, medium

Topographic position: crest, midslope, lower slope Slope: $(0-2 \%)^{5}(16-30 \%)^{3}(31-45 \%)^{1}(45-70 \%)^{1}$

Aspect: south, southwest, west

\section{SOIL CHARACTERISTICS}

Organic thickness: $(0-2)(2-5)$

Humus form: mull

Surface texture: CL,SiL, L

Effective texture: CL, SiL, SL,

Depth to Mottles/Gley: none

Drainage: well

Parent material: F, GF, M

Soil subgroup: O.BL, O.DG, O.MB

\section{COMMUNITY TYPES}

SASMA8 Rough fescue-Idaho fescue-Parry oatgrass $(n=4)$ 


\section{cc1a grazed rough fescue $(n=46)$}

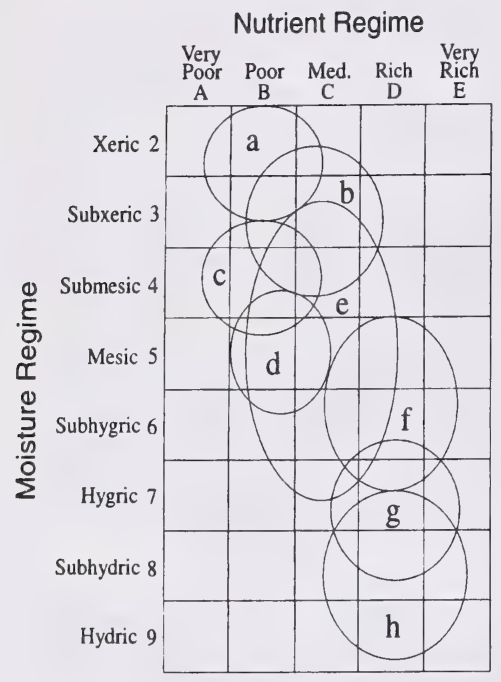

\section{CHARACTERISTIC SPECIES}

\section{Shrubs}

[4] Shrubby cinquefoil

[2] Rose

[1] Saskatoon

\section{Forbs}

[4] Dandelion

[1] Strawberry

[2] Old man's whiskers

[2] Yarrow

[2] Clover

[3] Graceful cinquefoil

\section{Graminoids}

[8] Rough fescue

[1] Idaho fescue

[2] Parry oatgrass

[1] Sedge

[ 15 ]Kentucky bluegrass

[8] Timothy

\section{SITE CHARACTERISTICS}

Moisture regime: submesic, mesic

Nutrient regime: rich, medium

Topographic position: crest, midslope, lower slope Slope: $(0-2 \%)^{5}(16-30 \%)^{3}(31-45 \%)^{1}(45-70 \%)^{1}$

Aspect: south, southwest, west

\section{SOIL CHARACTERISTICS}

Organic thickness: $(0-2)(2-5)$

Humus form: mull

Surface texture: CL,SiL, L

Effective texture: CL, SiL, SL,

Depth to Mottles/Gley: none

Drainage: well

Parent material: F, GF, M

Soil subgroup: O.BL, O.DG, O.MB

\section{COMMUNITY TYPES}

SASMA5 Kentucky bluegrass/Dandelion( $\mathrm{n}=14$ ) SASMC1 Parry oatgrass-Rough fescue-Kentucky bluegrass $(\mathrm{n}=7)$

SASMC3 Meadow foxtail-Kentucky bluegrass( $n=3$ )

SASMC5 Rough fescue-Kentucky bluegrass $(\mathrm{n}=1)$

SASMC6 Kentucky bluegrass-Rough fescue $(n=13)$

SASMC7 Timothy-Slender

wheatgrass/Fireweed $(\mathrm{n}=8)$ 
cc2 shrubland ( $\mathrm{n}=1)$

\section{CHARACTERISTIC SPECIES}

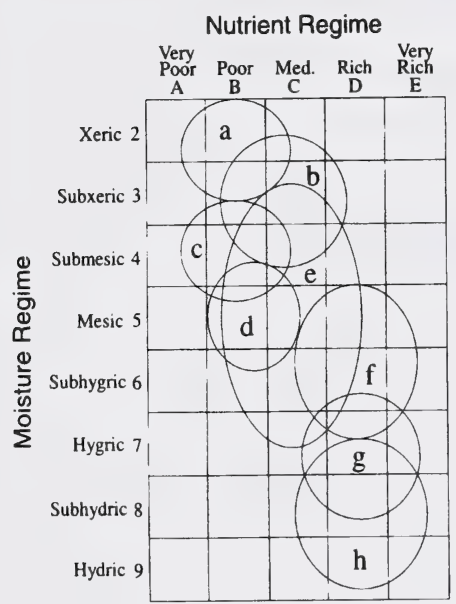

Topographic position: crest, midslope Slope: (16-30\%)

Aspect: south

\section{SOIL CHARACTERISTICS}

Organic thickness: $(0-2)(2-5)$

Humus form: mull

Surface texture: CL,SiL, L

Effective texture: CL, SiL, SL,

Depth to Mottles/Gley: none

Drainage: well

Parent material: F, GF, M

Soil subgroup: O.BL, O.DG, O.MB

\section{COMMUNITY TYPES}

SASMA15 Silverberry-Rose $(n=1)$

Trees

[8] Aspen

\section{Shrubs}

[15] Silverberry

[5] Rose

\section{Forbs}

[6] Chickweed

[2] False dandelion

[1] Silver plant

\section{Graminoids}

[1] Rocky mtn. fescue

[9] Bluebunch wheatgrass 


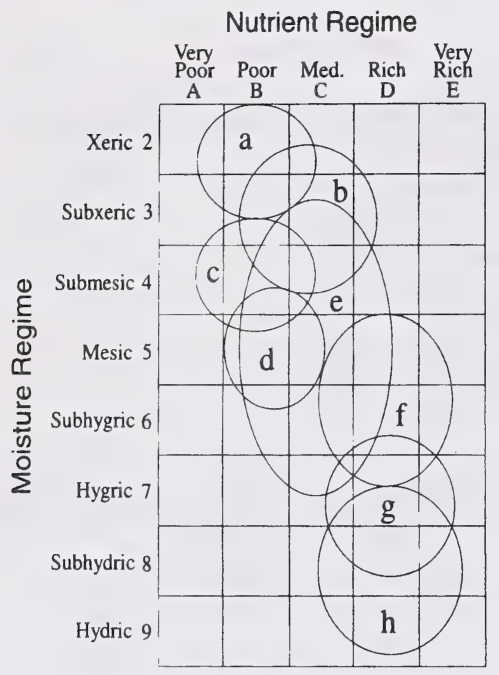

\section{CHARACTERISTIC SPECIES}

Shrubs

[3] Shrubby cinquefoil

[2] Rose

Forbs

[3] Graceful cinquefoil

[4] Yellow hedysarum

[2] American vetch

[6] Fireweed

[1] Strawberry

\section{Graminoids}

[2] Parry oatgrass

[3] Hairy wildrye

[2] Rough fescue

\section{SITE CHARACTERISTICS}

Moisture regime: mesic, subhygric

Nutrient regime: rich, medium

Topographic position: lower slope

Slope: (0-8\%)

Aspect: south, level

\section{SOIL CHARACTERISTICS}

Organic thickness: (6-15)

Humus form: moder

Surface texture: SL,SiL, L,C

Effective texture: $\mathrm{CL}, \mathrm{SiL}, \mathrm{SCL}$,

Depth to Mottles/Gley: none, (0-25)

Drainage: well, mod. well

Parent material: F, C, M, X

Soil subgroup: O.EB, E.DYB, O.EB, BR.GL

\section{COMMUNITY TYPES}

SASMA16 Forb meadow $(\mathrm{n}=1)$ 


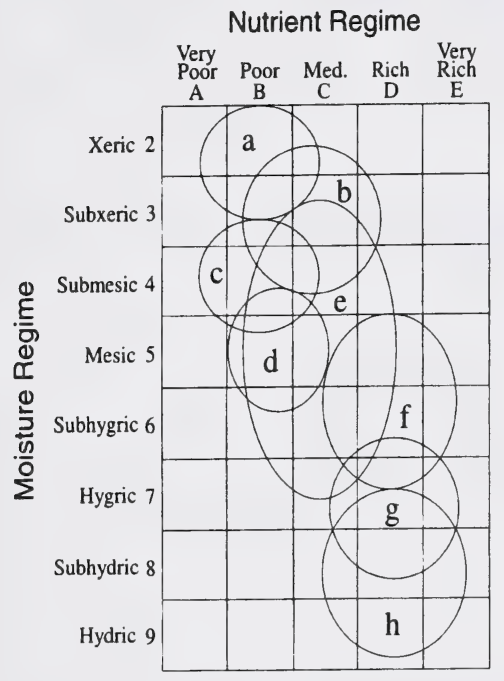

\section{SITE CHARACTERISTICS}

Moisture regime: mesic

Nutrient regime: medium

Topographic position: midslope, lower slope, floodplain

Slope: $(0-5 \%)$

Aspect: south, level

\section{SOIL CHARACTERISTICS}

Organic thickness: $(0-2)(2-5)$

Humus form: mor

Surface texture: SL,SiL, L

Effective texture: CL, SiL, SCL,

Depth to Mottles/Gley: none

Drainage: well, mod. well

Parent material: F, C, M

Soil subgroup: O.EB, E.DYB, O.EB, BR.GL

\section{COMMUNITY TYPES}

\section{CHARACTERISTIC SPECIES}

\section{Trees}

[ 20 ]Aspen

[ 10 ]Balsam poplar

Shrubs

$\begin{array}{ll}\text { [2] } & \text { Silverberry } \\ {[7]} & \text { Rose } \\ \text { [3] } & \text { White meadowsweet } \\ \text { Forbs } & \end{array}$

[5] American vetch

[6] Yellow peavine

[4] Strawberry

[4] Fireweed

[4] Showy aster

[1] Alpine hedysarum

Graminoids

[ 14 ]Pinegrass

[6] Hairy wildrye

[1] Junegrass
SASMD1 $\mathrm{Pb} /$ Silver berry(n=1)

SASMD2 Aw/Rose/Pinegrass( $\mathrm{n}=20)$ 


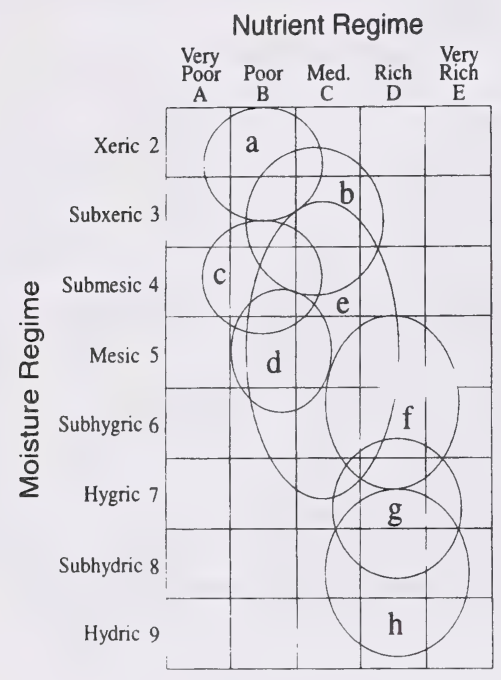

\section{CHARACTERISTIC SPECIES}

\section{Trees}

[35] Aspen

[ 3 ] White spruce

Shrubs

[5] Gooseberry

[6] Rose

Forbs

[1] American vetch

[3] Yellow peavine

[3] Strawberry

[6] Fireweed

[13] Lindley aster

[2] Dandelion

Graminoids
[4] Pinegrass
[2] Kentucky bluegrass
[18] Canada bluegrass
[16] Meadow foxtail
[9] Orchardgrass
[3] Timothy

\section{SITE CHARACTERISTICS}

Moisture regime: mesic

Nutrient regime: medium

Topographic position: midslope, lower slope

Slope: $(0-5 \%)$

Aspect: south, level

SOIL CHARACTERISTICS

Organic thickness: $(0-2)(2-5)$

Humus form: mor

Surface texture: SL,SiL, L

Effective texture: CL, SiL, SCL,

Depth to Mottles/Gley: none

Drainage: well, mod. well

Parent material: F, C, M

Soil subgroup: O.EB, E.DYB, O.EB, BR.GL

\section{COMMUNITY TYPES}

SASMD3 Aw/Fireweed/Meadow foxtail( $\mathrm{n}=1)$ SASMD4 Aw/Rose/Canada bluegrass(n=1) 


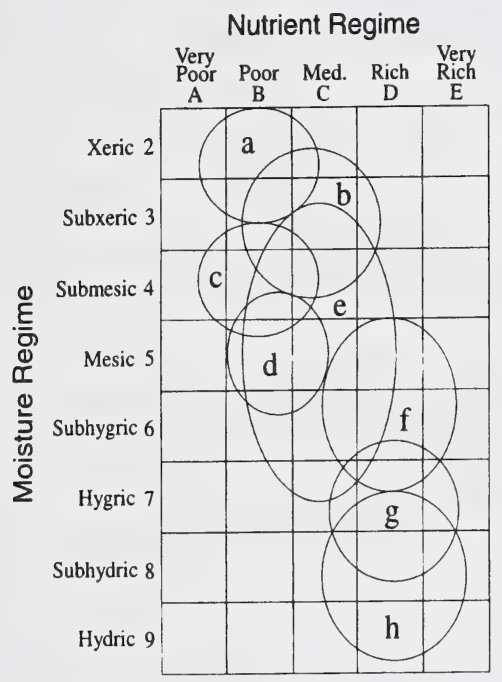

\section{CHARACTERISTIC SPECIES}

\section{Shrubs}

[1] Shrubby cinquefoil

[9] Rose

\section{Forbs}

[4] Lupine

[2] Yellow peavine

[3] Dandelion

[1] Graceful cinquefoil

[3] Showy aster

[1] False mtn. dandelion

Graminoids

[11 ]Pinegrass

[2] Junegrass

[4] Hairy wildrye

[3] Kentucky bluegrass

\section{SITE CHARACTERISTICS}

Moisture regime: mesic

Nutrient regime: medium

Topographic position: crest, midslope, lower slope Slope: (16-30\%)

Aspect: southerly

\section{SOIL CHARACTERISTICS}

Organic thickness: $(0-2)(2-5)$

Humus form: mull

Surface texture: CL,SiL, L

Effective texture: CL, SiL, SL,

Depth to Mottles/Gley: none

Drainage: well, rapid

Parent material: $\mathrm{C}, \mathrm{M}$

Soil subgroup: O.EB, O.MB, O.DG

\section{COMMUNITY TYPES}

SASMA15 Pinegrass-Hairy

wildrye/Strawberry $(n=4)$ 


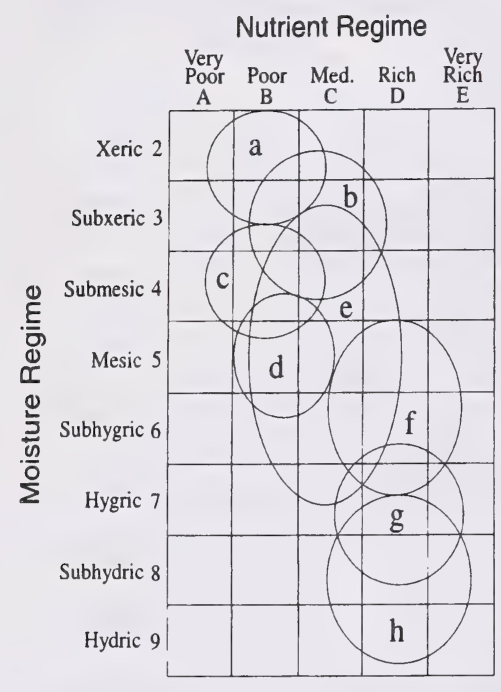

\section{CHARACTERISTIC SPECIES}

\section{Trees}

[ 30 ]Aspen

[ 10 ]Balsam poplar

\section{Shrubs}

[6] Gooseberry

[1] Rose

Forbs

[ 48 ]Cow parsnip

[2] Yellow peavine

[15]Canada violet

[6] Fireweed

[22]Lindley aster

[ 12 ]Tall lungwort

[ 12 ]Tall larkspur

Graminoids

[1] Marsh reedgrass

[2] Hairy wildrye

[2] Sedge

\section{SITE CHARACTERISTICS}

Moisture regime: subhygric

Nutrient regime: rich

Topographic position: lower slope

Slope: (0-8\%)

Aspect: south, level

\section{SOIL CHARACTERISTICS}

Organic thickness: (6-15)

Humus form: moder

Surface texture: SL,SiL, L,C

Effective texture: CL, SiL, SCL,

Depth to Mottles/Gley: none, (0-25)

Drainage: well, mod. well

Parent material: F, C, M, X

Soil subgroup: O.EB, E.DYB, O.EB, BR.GL

\section{COMMUNITY TYPES}

SASMD5 Aw-Pb/Cow parsnip(n=3) 


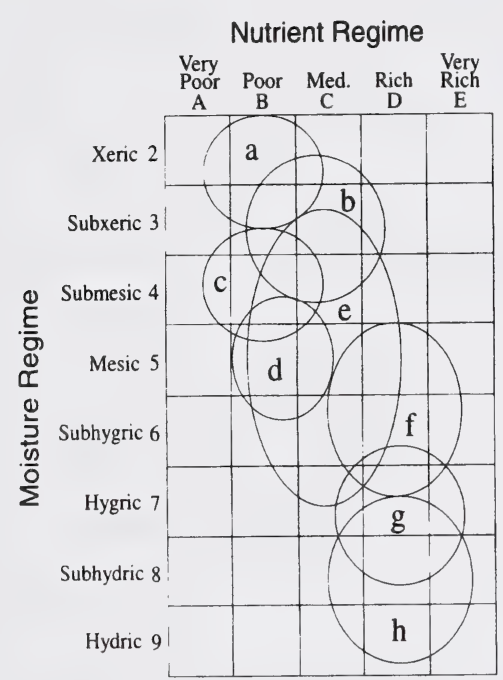

Moisture regime: subhygric

Nutrient regime: rich

Topographic position: lower slope, midslope Slope: $(0-8 \%)$

Aspect: south, level, north

\section{SOIL CHARACTERISTICS}

Organic thickness: (6-15)

Humus form: moder

Surface texture: SL,SiL, L,C

Effective texture: CL, SiL, SCL,

Depth to Mottles/Gley: none, (0-25)

Drainage: well, mod. well

Parent material: F, C, M, X

Soil subgroup: O.EB, E.DYB, O.EB, BR.GL

\section{COMMUNITY TYPES}

SASMD6 Aw-Pb/Cow parsnip/Timothy(n=1)

\section{CHARACTERISTIC SPECIES}

\section{Trees}

[26] Aspen

[16] Balsam poplar

Shrubs

[4] Raspberry

[1] Rose

Forbs

[2] Cow parsnip

[2] Yellow peavine

[2] Canada violet

[6] Fireweed

[19] Lindley aster

[12] White geranium

[6] Dandelion

Graminoids

[4] Marsh reedgrass

[18] Timothy

[4] Kentucky bluegrass

[7] Smooth wildrye 
f4 shrubby seepage $(n=1)$

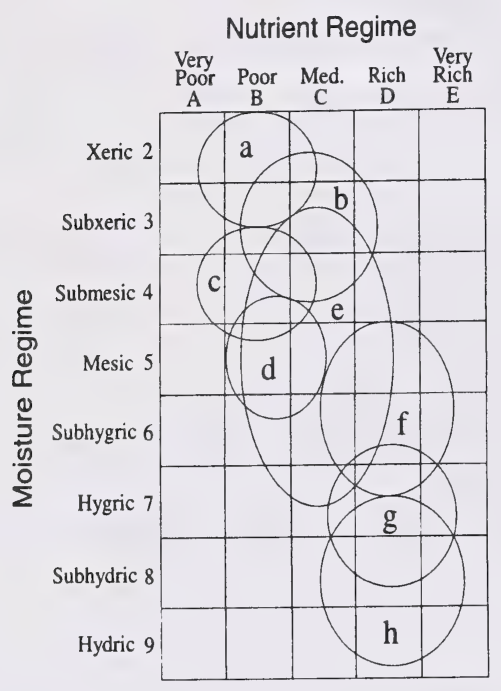

Moisture regime: subhygric

Nutrient regime: rich

Topographic position: lower slope, midslope Slope: (0-8\%)

Aspect: south, level, north

\section{SOIL CHARACTERISTICS}

Organic thickness: (6-15)

Humus form: moder

Surface texture: SL,SiL, L,C

Effective texture: $\mathrm{CL}, \mathrm{SiL}, \mathrm{SCL}$,

Depth to Mottles/Gley: none, (0-25)

Drainage: well, mod. well

Parent material: F, C, M, X

Soil subgroup: O.EB, E.DYB, O.EB, BR.GL

\section{COMMUNITY TYPES}

SASMA7a Marsh reedgrass/Cow parsnip/(n=1)

\section{CHARACTERISTIC SPECIES}

Shrubs

[1] Raspberry

[4] Rose

Forbs

[3] Cow parsnip

[ 10 ]Western meadow rue

[4] Canada violet

[25]Fireweed

[4] Horsetail

[4] Sticky purple geranium

[1] Dandelion

Graminoids

[ 24 ]Marsh reedgrass

[ 15 ]Sedge

[5] Idaho fescue

[2] Brome 


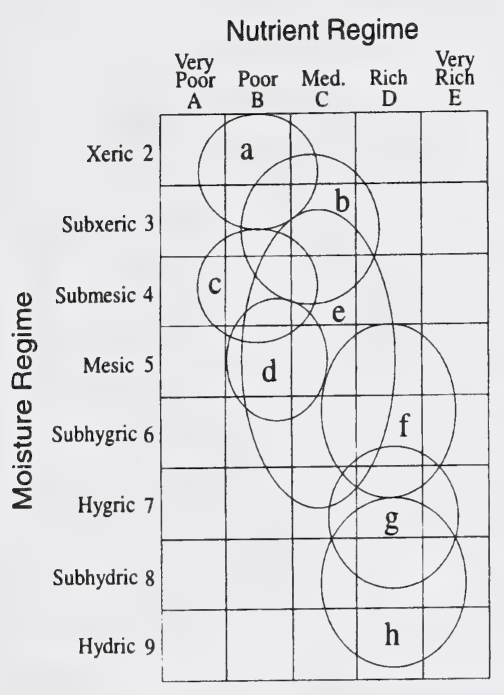

\section{CHARACTERISTIC SPECIES}

\section{Shrubs}

[6] Raspberry

\section{Forbs}

[ 28 ]Cow parsnip

[ 15 ]Western meadow rue

[ 20 ]Canada violet

[3] Fireweed

[1] Horsetail

[ 10 ]White geranium

[3] Dandelion

Graminoids

[ 37 ]Marsh reedgrass

[1] Sedge

[29 ]Timothy

[2] Mountain brome
Moisture regime: subhygric

Nutrient regime: rich

Topographic position: lower slope, midslope

Slope: $(0-8 \%)$

Aspect: south, level, north

\section{SOIL CHARACTERISTICS}

Organic thickness: (6-15)

Humus form: moder

Surface texture: SL,SiL, L,C

Effective texture: $\mathrm{CL}, \mathrm{SiL}, \mathrm{SCL}$,

Depth to Mottles/Gley: none, (0-25)

Drainage: well, mod. well

Parent material: F, C, M, X

Soil subgroup: O.EB, E.DYB, O.EB, BR.GL

\section{COMMUNITY TYPES}

SASMC8 Marsh reedgrass-Timothy/Cow parsnip/(n=1) 
i fen $(\mathrm{n}=8)$ (taken from Ecosites of WestCentral Alberta)

\section{GENERAL DESCRIPTION}

The rich and poor fen are combined in this ecosite. The fen ecosite is generally characterized by flowing oxygenated water and alkaline, nutrientrich conditions. This ecosite occupies level, depressional and lower slope positions where impeded drainage or high water tables enhance the accumulation of organic matter consisting of sedges, golden moss, tufted moss, and brown moss. Black and/or Engelmann spruce dominate the canopy of the treed phase, while dwarf birch or willow form the canopy of the shrubby phase and sedges dominate the graminoid phase.

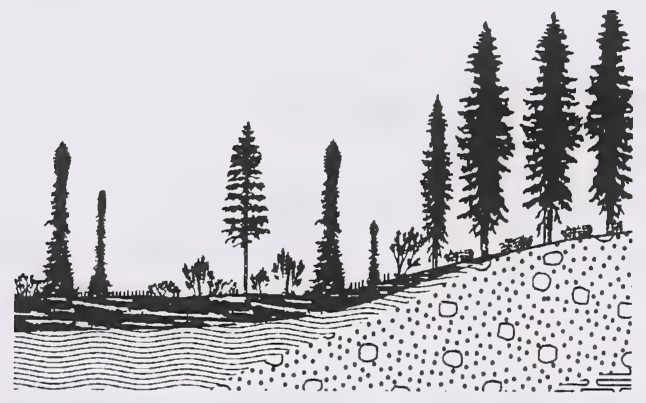

\section{SUCCESSIONAL RELATIONSHIPS}

The fen is an early stage in hydarch succession. Species composition, direction, and rate of succession changes with changing hydrologic regime. As with other wetlands, rich fens have slow successional rates so recovery from disturbance may also be slow.

\section{INDICATOR SPECIES}

Black spruce

Engelmann spruce

Willow

Labrador tea

Dwarf birch

Horsetail

Sedge

Golden moss

Brown moss
Tufted moss

subhydric/rich

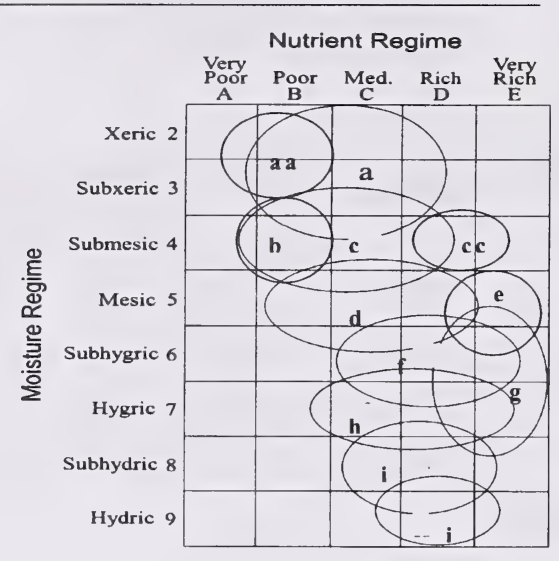

\section{SITE CHARACTERISTICS}

Moisture regime: subhygric, hygric, subhydric,hydric

Nutrient regime: rich, very rich, medium

Topographic position: level, depression, toe Slope: level, $(0-1 \%)$

Aspect: level, southerly, easterly

\section{SOIL CHARACTERISTICS}

Organic thickness: $(>80)(60-79)$

Humus form: mor, peaty mor

Surface texture: fibric, mesic

Effective texture: fibric, mesic

Depth to Mottles/Gley: not applicable

Drainage: imperfect, poor, very poor

Parent material: O

Soil subgroup:R.G, TY.M, TY.F, T.M, T.F, R.HG, O.HG, O.G, FI.M

\section{ECOSITE PHASES}

i1 shrub fen $(n=4)$

i2 graminoid fen $(n=4)$ 


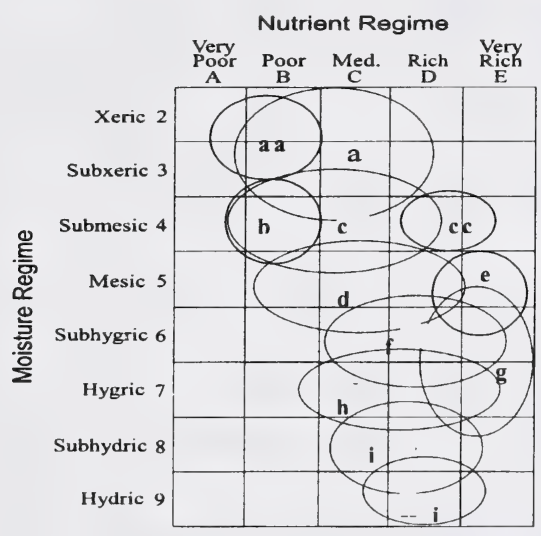

\section{CHARACTERISTIC SPECIES}

Shrub

[ 25 ]Willow

[5] Shrubby cinquefoil

[3] Dwarf birch

Forb

[ 3 ] Lindley's aster

[6] Strawberry

[4] Arrow leaved coltsfoot

[2] Horsetail

[1] Cow parsnip

\section{Grass}

[25]Sedge

[2] Tufted hairgrass

[6] Baltic rush

[2] Tufted hairgrass

\section{SITE CHARACTERISTICS}

Moisture regime: subhygric, subhydric Nutrient regime: very rich, rich medium Topographic position: level, depression Slope: level, $(0-2 \%)$

Aspect: variable

\section{SOIL CHARACTERISTICS}

Organic thickness: $(>80)(60-79)$

Humus form: mor, peaty mor Surface texture: fibric, mesic Effective texture: fibric, mesic Depth to Mottles/Gley: not applicable Drainage: imperfect, poor, very poor

Parent material: $\mathrm{O}$

Soil subgroup:R.G, TY.M, TY.F, T.M, T.F, R.HG, O.HG, O.G, FI.M

\section{PLANT COMMUNITY TYPES}

SASMB1 Willow/Sedge $(\mathrm{n}=2)$

SASMB5 Willow/Marsh reedgrass $(\mathrm{n}=2)$ 
graminoid fen $(n=4)$

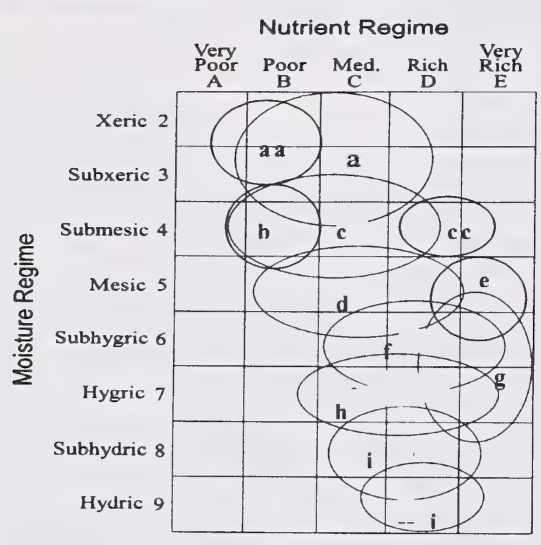

\section{CHARACTERISTIC SPECIES}

Shrub

\section{[1] Willow}

Forb

[ 1 ] Northern bedstraw

[1] Fireweed

\section{Grass}

[ 81 ]Water sedge

[4] Tufted hairgrass

\section{SITE CHARACTERISTICS}

Moisture regime: hygric, subhydric

Nutrient regime: very rich, rich

Topographic position: level, depression

Slope: level, (0-2\%)

Aspect: variable

\section{SOIL CHARACTERISTICS}

Organic thickness: $(>80)(60-79)$

Humus form: mor, peaty mor

Surface texture: fibric, mesic

Effective texture: fibric, mesic

Depth to Mottles/Gley: not applicable

Drainage: imperfect, poor

Parent material: O

Soil subgroup:R.G, TY.M, TY.F, T.M, T.F, R.HG, O.HG, O.G, FI.M

\section{PLANT COMMUNITY TYPES}

SASMA1 Sedge meadows $(n=4)$ 
లై

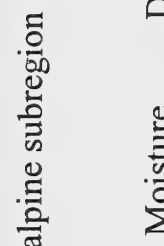

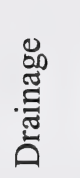

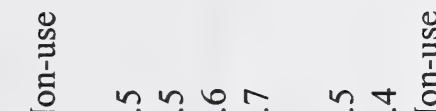

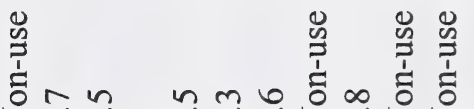

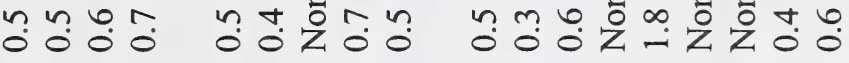

$\frac{0}{3}$

$\sin$

$\ddot{2}$

突色

它

흥 융

D. I

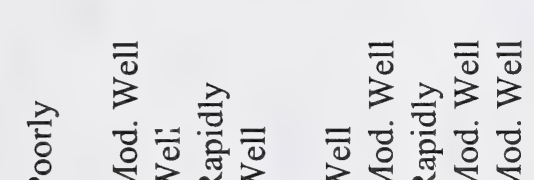

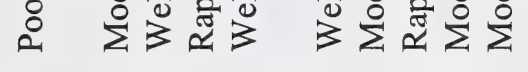

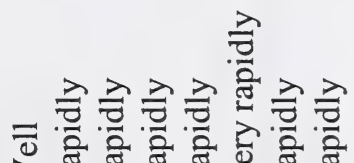

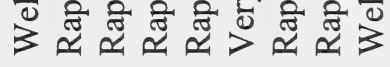

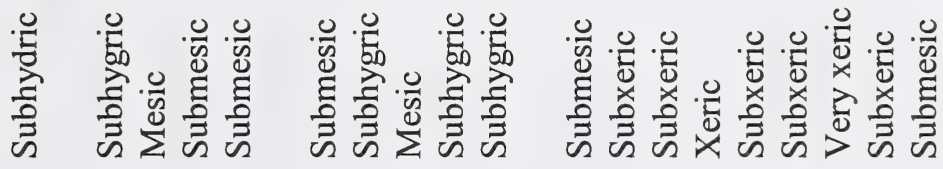

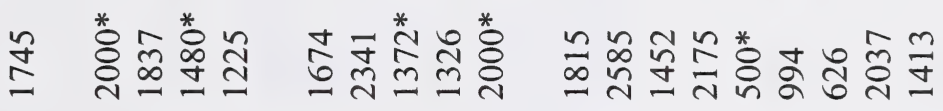

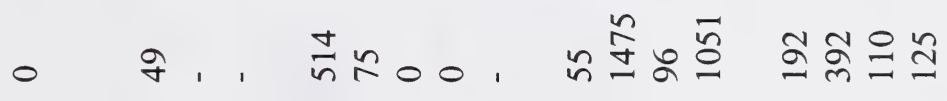

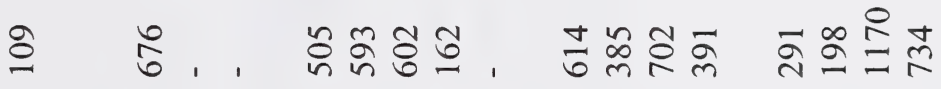

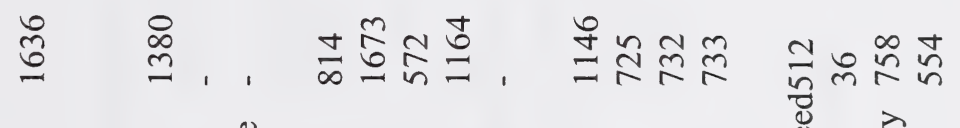

E⿱

嵌

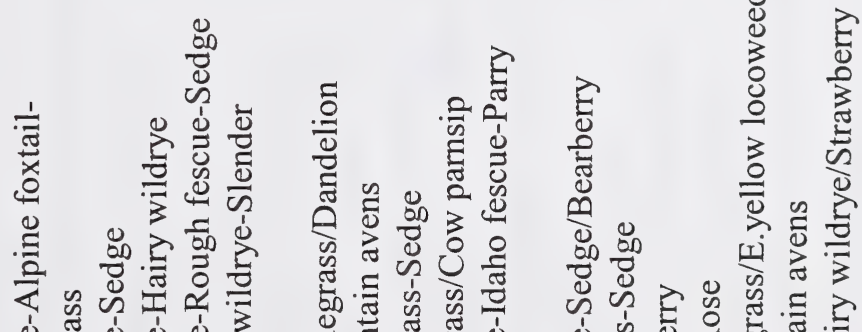
च ₹थै

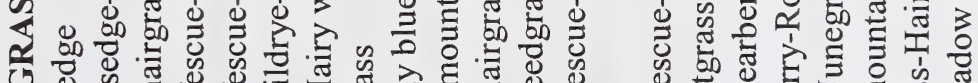

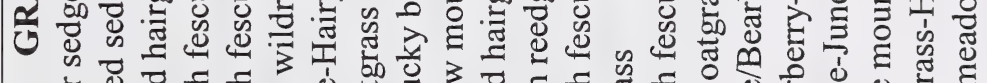

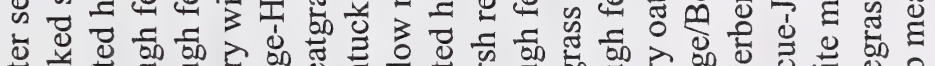
可

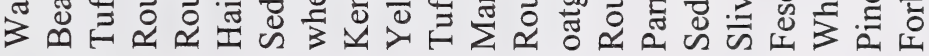

咅

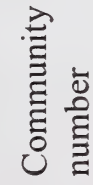

¿

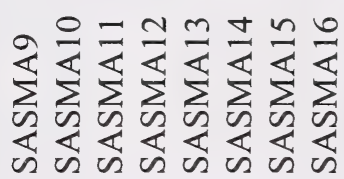


昌, , ํㅡ,

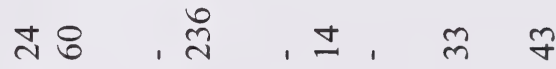

일

흥 윰

m, , 穴,

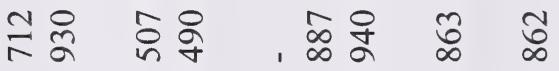

ป⿱艹

$\stackrel{n}{\mathfrak{c}}$

8

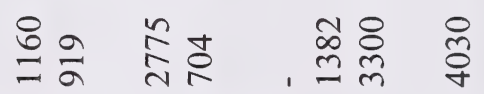

京

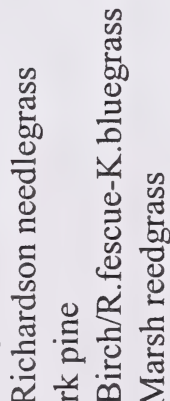

然

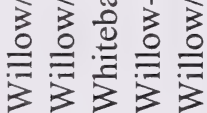

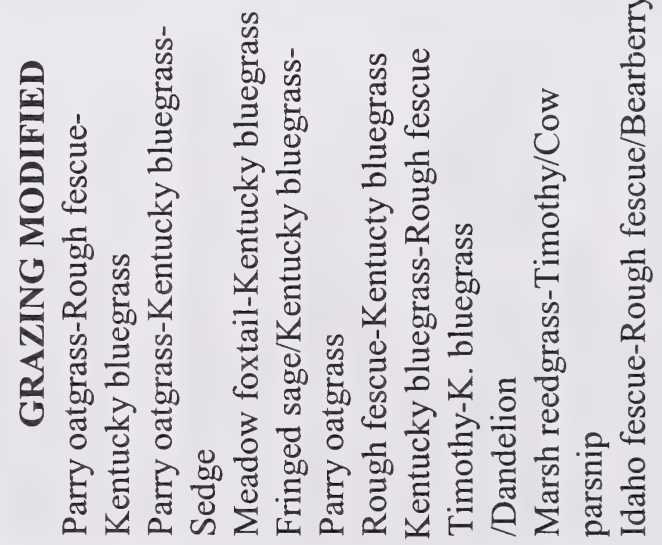

言

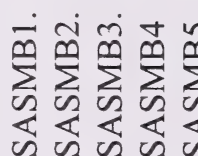

$\sum_{\substack{n \\ 0}}^{\infty} \sum^{5}$

$\sum_{\infty}^{\infty}$

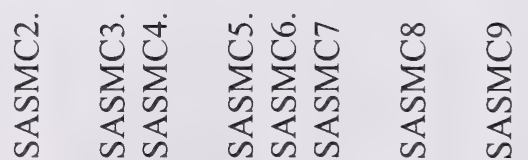



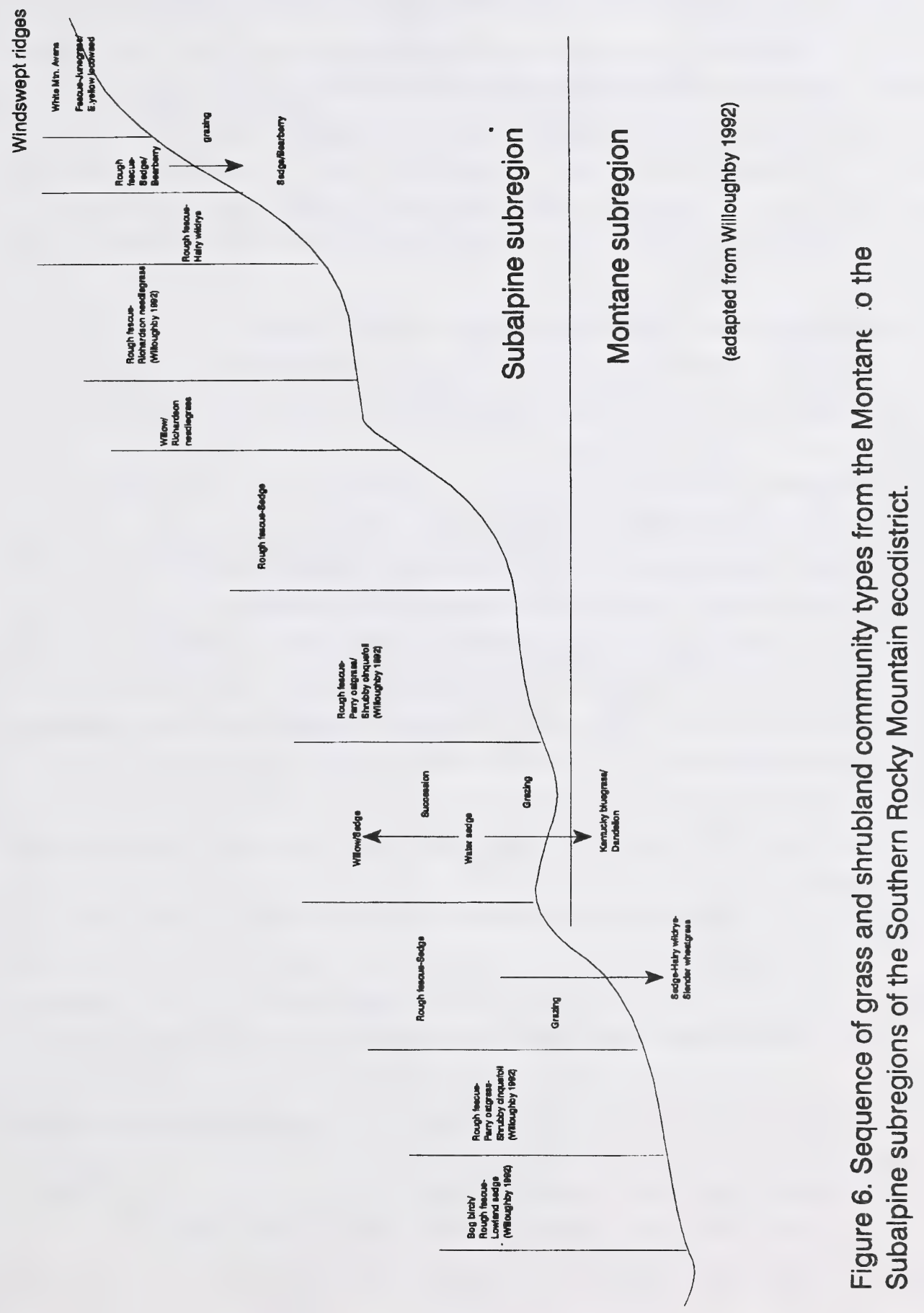
Key to grass and shrubland dominated communities in the Southern mountains of the Subalpine subregion.

1. Timberline communities or windswept ridges at timberline..................................... 2

Meadow communities or south facing grasslands at lower elevations...................... 4

2. Plant community dominated by Whitebark pine................................SASMB3

Windswept ridges dominated by white mtn. avens, Idaho fescue or junegrass....... 3

3. Community dominated by white $\mathrm{mtn}$. avens.................................SASMA14

Grass dominated community dominated by Idaho fescue and Junegrass....SASMA13

4. Moist meadows or gravelly river flats dominated by shrubs, tufted hairgrass, sedge, yellow mtn. avens or silverberry.

Drier south and north facing slopes dominated by rough fescue, parry oatgrass, upland sedges, hairy wildrye, pinegrass us u.rb dominated meadows with fireweed......................... 13

5. Dry gravelly river flats dominated by yellow mtn. avens or silverberry..................... $\quad 6$ Moist sites dominated by willow, bog birch or grassy areas dominated by tufted hairgrass, sedge, marsh reedgrass, kentucky bluegrass and dandelion

6. Site dominated by yellow mtn. avens.....................................................SASMA6

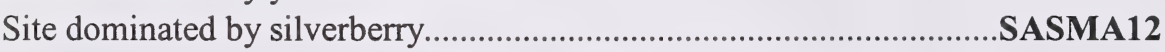

7. Willow or bog birch dominated community types................................................... 8

Grass dominated meadows (tufted hairgrass, marsh reedgrass, alpine foxtail, beaked sedge, water sedge, kentucky bluegrass)............................................................................. 11

8. Wetter sites dominated by sedge or marsh reedgrass in the understory.................... 9

Drier, sites dominated by richardson needlegrass or rough fescue in understory....... $\quad 10$

9. Understory dominated by marsh reedgrass........................................SASMB5

Understory dominated by sedge.

SASMB1

10. Dry south facing slopes in Athabasca river valley near Jasper, dominated by Richardson needlegrass in understory. SASMB2

Understory dominated by rough fescue.

11. Very wet sites dominated by water sedge

SASMA1

Drier sites dominated by tufted hairgrass, graceful sedge, marsh reedgrass, alpine foxtail or

Kentucky bluegrass.

12 Ungrazed sites dominated by tufted hairgrass, beaked sedge, alpine foxtail, marsh reedgrass,

or graceful sedge. $12 \mathrm{a}$

Grazed sites dominated by Kentucky bluegrass, timothy or dandelion.

12a Marsh reedgrass and cow parsnip dominated grassy meadows. SASMA7a

Tufted hairgrass, beaked sedge, alpine foxtail or graceful sedge dominated meadow.

12b Marsh reedgrass, timothy, cow parsnip dominated meadows. SASMC8

Heavy grazing pressure site dominated by Kentucky bluegrass and dandelion.....SASMA5

12c Tufted hairgrass, graceful sedge dominated meadows. SASMA7

Beaked sedge, Alpine foxtail dominated meadow. SASMA1a

13. Ungrazed rough fescue, hairy wildrye, pinegrass or forb dominated grasslands.

Moderately to heavily grazed grasslands

14. Pinegrass or forb (fireweed) dominated meadows 
Rough fescue, parry oatgrass, hairy wildrye, bearberry dominated grasslands.

15 Site dominated by forbs, moist seepage area SASMA16

Pinegrass, hairy wildrye dominated grassland

SASMA15

16. Rough fescue dominated grasslands, south and west of Turner valley, hairy wildrye and sedge dominate or co-dominate grassland.

Rough fescue dominated grasslands, west of Porcupine Hills and in Castle area, codominated by Parry oatgrass, sedge or bearberry.

17. Grasslands of south facing slopes, sedge co-dominated.

Grasslands of lower slope positions or north aspects, dominated or co-dominated by hairy wildrye.

17a Grassland dominated by hairy wildrye, north aspects on steep ridges.....SASMA3a Grasslands co-dominated by hairy wildrye, south facing SASMA3

18. Grasslands of lower slope positions dominated by Rough fescue SASMA8

Grasslands of mid to upper slope positions dominated by Parry oatgrass, Idaho fescue or bearberry.

19. Grasslands of midslope position dominated by Parry oatgrass, Idaho fescue....SASMA10 Grasslands of upper slope positions or hillcrests co-dominated by bearberry....SASMA9

20. Moderately grazed grasslands native grass species still dominate the site. Heavily grazed grasslands non-native species (Kentucky bluegrass, timothy, meadow foxtail) dominate or co-dominate the site.

21 Drier sites with bearberry $.21 \mathrm{a}$

Moister sites dominated by sedge, hairy wildrye and slender wheatgrass.. SASMA4

21a Grassy areas with a high cover of Idaho fescue and Rough fescue. SASMC9 Sedge dominates the grass layer. SASMA11

22. Old range improvement dominated by meadow foxtail. SASMC3 Meadow foxtail not present grazed sites.

23 Kentucky bluegrass or timothy dominated sites.

Kentucky bluegrass only co-dominate, Parry oatgrass or rough fescue or fringed sage dominates

24. Timothy dominated community..... SASMC7 Kentucky bluegrass, dandelion dominated. SASMC6

25. Rough fescue dominates the site. SASMC5 Parry oatgrass or Fringed sage dominate the site SASMC4

26. Hillcrests and south facing slopes dominated by fringed sage Parry oatgrass dominated community types.

27. Parry oatgrass with Rough fescue and Kentucky bluegrass, lower slope.......SASMC1 Little rough fescue present, midslope position. SASMC2 


\section{SASMA1. Water sedge (Carex aquatilis)}

$\mathrm{n}=4 \quad$ This community type is found in all ecodistricts of the subalpine. Wet conditions and periodic flooding result in the formation of water sedge meadows. Willow will invade into the drier edges of these meadows to form the Willow/Water sedge community type. These community types are quite productive producing nearly $2000 \mathrm{~kg} / \mathrm{ha}$ of forage, but the high water table in the spring and summer when these meadows are most palatable limits livestock use. A study in the Yukon found that crude protein on these meadows declined from a high of $10 \%$ in May to less than $5 \%$ in September (Bailey et al. 1992). As a result, these meadows would be rated as secondary or non-use range.

\section{Plant Composition Canopy Cover(\%)} MEAN RANGe CONST.

SHRUBS

WILLOW

(Salix spp.)

T $\quad-\quad 25$

\section{FORBS}

FIREWEED

(Epilobium angustifolium) $\mathrm{T}$

NORTHERN BEDSTRAW

(Galium boreale)

1

$0-1 \quad 50$

$0-5 \quad 25$

\section{GRASSES}

WATER SEDGE

(Carex aquatilis)

TUFTED HAIRGRASS

(Deschampsia cespitosum) 3

$0-9 \quad 75$

\section{ENVIRONMENTAL VARIABLES}

MOISTURE REGIME :

SUBHYDRIC

NUTRIENT REGIME:

MESOTROPHIC

ELEVATION:

1600-1981(1859) M

SOIL DRAINAGE:

POORLY

Forage Production
GRASS $1636(636-2636)$

FORB $109(0-218)$

TOTAL $1745(636-2854)$

\section{SUGGESTED GRAZING CAPACITY NON-USE}




\section{SASMA1a. Beaked sedge-Alpine foxtail-Tufted hairgrass \\ (Carex atherodes-Alopecurus occidentalis-Deschampsia cespitosa)}

$\mathbf{n}=1$ This community type was described in a meadow adjacent to a small creek. It is similar to the previously described water sedge community, but this community type is better drained which favours the growth of beaked sedge, alpine foxtail and tufted hairgrass. On the drier edges of this community type upland grass species like rough fescue and Idaho fescue can be found. Willoughby (1992) has found that beaked sedge is palatable to livestock, which causes these meadows to be regularly grazed. Heavy grazing will allow Kentucky bluegrass, timothy and dandelion to invade onto these sites.

Plant Composition Canopy Cover(\%)

\section{MEAN RANGe CONST.}

\section{SHRUBS}

WILLOW

(Salix spp.)

1

100

FORBS

FIREWEED

(Epilobium angustifolium) 3

MARSH CINQUEFOIL

(Poa palustre)

SMOOTH ASTER

(Aster laevis)

40

18

MOUNTAIN CINQUEFOIL

(Potentilla diversifolia)

\section{ENVIRONMENTAL VARIABLES}

MOISTURE REGIME :

SUBHYGRIC

NUTRIENT REGIME:

PERMESOTROPHIC

ELEVATION:

$1640 \mathrm{M}$

SOIL DRAINAGE:

MODERATELY WELL

Forage Production

TOTAL $2000 *$ EsTIMATE

100

100

100

100

SUGgESTED GRAZING CAPACITY

$0.5 \mathrm{HA} / \mathrm{AUM}$

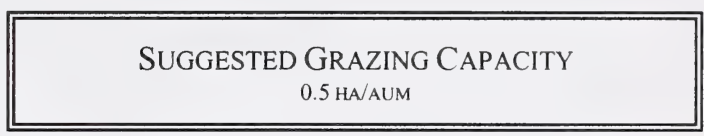

IDAHO FESCUE

(Festuca idahoensis) 


\section{SASMA2. Rough fescue-Sedge \\ (Festuca scabrella-Carex spp.)}

$\mathbf{n}=\mathbf{2 3}$ This community type appears to be the modal grassland community type found on level and gentle south -facing slopes in the Southern Rocky Mountains of the Subalpine subregion. The dominance of rough fescue indicates that this grassland is transitional from the lower Montane subregion. As one moves up in elevation there is a shift away from a Rough fescue-Parry oatgrass dominated community type to a Rough fescue Sedge dominated community type. Willoughby (1992), found that blunt sedge replaced Parry oatgrass as dominant or codominant on steep south-facing slopes, and Richardson needlegrass replaced Parry oatgrass as codominant on more mesic sites in this area. This community type includes both the Rough fescue-Sedge, Kough fescue-Richardson needlegrass and Rough fescue-Parry oatgrass/Shrubby cinquefoil community types described by Willoughby (1992).

Jaques (1976), described a similar community type from Plateau Mountain to Mount Allan. He felt this community type represented critical wildlife habitat because it remained snow-free for a majority of the winter. Grazing by livestock on these community types should be managed carefully in order to maintain a carryover for wildlife in the winter.

\section{Plant COMPOSITION CANopy COVER(\%) Mean RANGe CONST.}

\section{SHRUBS}

SHRUBBY CINQUEFOIL

(Potentilla fruticosa)

$\begin{array}{lll}5 & 0-19 \quad 84\end{array}$

FORBS

YARROW

\begin{tabular}{|c|c|c|}
\hline (Achillea millefolium) & 5 & $0-17$ \\
\hline YELLOW BEARDSTONGUE & & \\
\hline (Penstemon confertus) & 5 & $0-39$ \\
\hline MOUSE EARED CHICKWEED & & \\
\hline (Cerastium arvense) & 2 & $0-6$ \\
\hline BEARBERRY & & \\
\hline (Arctostaphylos uva-ursi) & 3 & $0-25$ \\
\hline STRAWBERRY & & \\
\hline (Fragaria virginiana) & 5 & $0-11$ \\
\hline OLD MANS WHISKER'S & & \\
\hline (Geum triflorum) & 3 & $0-18$ \\
\hline
\end{tabular}

GRaSSES

ROUGH FESCUE

(Festuca scabrella)

18

$2-47$

100

BLUNT SEDGE

(Carex obtusata)

12

$0-28$

91

CALIFORNIA OATGRASS

(Danthonia californica) 11

(Stipa richardsonii) . 4

$0-43 \quad 78$

$0-22 \quad 48$
HAIRY WILDRYE

(Elymus innovatus) $\quad 5 \quad 0-34 \quad 61$

\section{ENVIRONMENTAL VARIABLES}

MOISTURE REGIME:

SUBMESIC-MESIC

NUTRIENT REGIME :

MESOTROPHIC

ELEVATION:

$$
\text { 1460-2024(1751) M }
$$

SOIL DRAINAGE:

WELL

SLOPE: $0-48(6) \%$

ASPECT SOUTHERLY

\section{Forage Production Kg/HA}

$\begin{array}{ll}\text { GRASS } & 1380(748-1972) \\ \text { FORB } & 676(224-1412) \\ \text { SHRUB } & 49(0-296) \\ \text { TOTAL } & 1837(1138-3103)\end{array}$

SUGGESTED GRAZING CAPACITY $0.5 \mathrm{HA} / \mathrm{AUM}, 1.2 \mathrm{AC} / \mathrm{AUM}$ 


\section{SASMA3. Rough fescue-Hairy wildrye \\ (Festuca scabrella-Elymus innovatus)}

$\mathbf{n}=\mathbf{9}$ This community is similar to the Rough fescue-Sedge community type (SASMA2) previously described, but it is found on drier, steeper slopes with poorer soils than the other rough fescue dominated community type. As one moves upslope there is a shift in codominance of sedge to hairy wildrye and an increase in cover of bearberry and juniper.

Corns and Achuff (1982), described hairy wildrye dominated community types on south facing slopes in the more northern ecodistricts. They felt these grasslands occurred on areas with frequent snow avalanching. It is possible that this community type is associated with deeper snow accumulation than the Rough fescue-Sedge dominated type previously described.

Plant Composition Canopy Cover(\%) MEAN RANGe CONST.

SHRUBS

SHRUBBY CINQUEFOIL.

(Potentilla fruticosa) $\quad 5 \quad 0-23 \quad 88$

CREEPING JUNIPER

$\begin{array}{llll}\text { (Juniperus horizontalis) } & 2 & 0-9 & 33\end{array}$

FORBS

BEARBERRY

(Arctostaphylos uva-ursi)9 $\quad 0-16 \quad 75$

YARROW

(Achillea millefolium) $\quad 3 \quad 2-6 \quad 100$

STRAWBERRY

$\begin{array}{llll}\text { (Fragaria virginiana) } & 4 & 1-9 & 100\end{array}$

YELLOW HEDYSARUM

(Hedysarum sulphurscens) 3

SILVERY PERENNIAL LUPINE

(Lupinus argenteus) 2

GRASSES

HAIRY WILDRYE

(Elymus innovatus) $\quad 24 \quad 15-57 \quad 100$

BLUNT SEDGE

(Carex obtusata)

$6 \quad 3-13 \quad 67$

ROUGH FESCUE

$\begin{array}{llll}\text { (Festuca scabrella) } \quad 37 & 8-57 & 100\end{array}$

PARRY OATGRASS

(Danthonia parryii)

$5 \quad 0-24 \quad 57$

\section{ENVIRONMENTAL VARIABLES}

MOISTURE REGIME:

SUBMESIC

NUTRIENT REGIME :

SUBMESOTROPHIC-MESOTROPHIC

ELEVATION:

1620-2042(1859)

SOIL DRAINAGE:

RAPIDLY

SLOPE:

$0-50(22) \%$

ASPECT:

SOUTHERLY

\section{Forage Production KG/HA}

TOTAL 1480(900-2502)

SUGGESTED GRAZING CAPACITY

$0.6 \mathrm{HA} / \mathrm{AUM}$ OR $1.4 \mathrm{AC} / \mathrm{AUM}$ 


\section{SASMA3a. Hairy wildrye- Rough fescue -Carex spp.}

(Elymus innovatus- Festuca scabrella-Sedge)

$\mathbf{n}=\mathbf{1} \quad$ This community is similar to the Rough fescue-Hairy wildrye community type (SASMA3) previously described, but this type was described on a site with a north aspect. Corns and Achuff (1982), described hairy wildrye dominated community types on south facing slopes in the more northern ecodistricts. They felt these grasslands occurred on areas with frequent snow avalanching. It would appear that this community type represents the transition between the northerly hairy wildrye dominated grasslands and the southerly rough fescue-hairy wildrye dominated grasslands.

This community type was described in an area that is difficult for livestock to access. It should likely be rated as non-use.

\section{Plant Composition Canopy Cover(\%)}

\section{SHRUBS}

\section{MEAN RANGe CONST.}

SHRUBBY CINQUEFOIL.

$\begin{array}{lll}\text { (Potentilla fruticosa) } & 2 & -\end{array}$

$\begin{array}{llll}\text { (Juniperus communis) } & 1 & - & 100\end{array}$

FORBS

YELLOW BEARDTONGUE

(Penstemon confertus)

MISSOURI GOLDENROD

(Solidago missouriensis) $2 \quad-\quad 100$

FIREWEED

(Epilobium angustifolium)4 - $\quad 100$

ALPINE HEDYSARUM

(Hedysarum alpinus) $\quad 5 \quad-\quad 100$

MOUNTAIN DANDELION

(Agoseris glauca)

2

100

GRASSES

HAIRY WILDRYE

(Elymus innovatus) $\quad 20 \quad-\quad 100$

BLUNT SEDGE

(Carex obtusata)

ROUGH FESCUE

(Festuca scabrella)

\section{ENVIRONMENTAL VARIABLES}

MOISTURE REGIME:

SUBMESIC

NUTRIENT REGIME :

SUBMESOTROPHIC

ELEVATION:

$1951 \mathrm{M}$

SOIL DRAINAGE:

WELL

SLOPE:

$30 \%$

ASPECT:

NORTHERLY

Forage Production KG/HA

TOTAL $1225(900-1500)$

Suggested GRAZING CAPACITY

$0.7 \mathrm{HA} / A U M$ OR $1.6 \mathrm{AC} / \mathrm{AUM}$ 


\section{SASMA4. Sedge-Hairy wildrye-Slender wheatgrass \\ (Carex obtusata-Elymus innovatus-Agropyron trachycaulum)}

$\mathbf{n}=15$ This community type appears to represent the result of moderate to heavy grazing pressure on a Rough fescue-Sedge dominated community type. Heavy grazing appears to cause rough fescue to decline and allows sedge to increase. Indeed Willoughby et al. (2003), described similar species composition changes with grazing on south facing slopes in the Montane subregion.

\section{Plant COMPOSITION CANopy COVER(\%) Mean Range Const.}

\section{SHRUBS}

SHRUBBY CINQUEFOIL

(Potentilla fruticosa)

$3 \quad 0-13 \quad 55$

\section{FORBS}

STRAWBERRY

\begin{tabular}{|c|c|c|}
\hline (Fragaria virginiana) & 11 & $1-17$ \\
\hline WHITE CAMUS & & \\
\hline (Zigadenus elegans) & $\mathrm{T}$ & $0-1$ \\
\hline $\begin{array}{l}\text { YARROW } \\
\text { (Achillea millefolium) }\end{array}$ & 12 & $1-15$ \\
\hline SMOOTH LEAVED CINQUEF & & \\
\hline $\begin{array}{l}\text { (Potentilla diversifolia) } \\
\text { BEARBERRY }\end{array}$ & 6 & $0-23$ \\
\hline $\begin{array}{l}\text { (Arctostaphylos uva-ursi, } \\
\text { YELLOW BEARDTONGUE }\end{array}$ & & $0-18$ \\
\hline (Penstemon confertus) & 1 & $0-14$ \\
\hline OLD MAN'S WHISKERS & & \\
\hline (Geum triflorum) & 7 & $0-11$ \\
\hline
\end{tabular}

GRASSES

HAIRY WILDRYE

$\begin{array}{lccc}\begin{array}{l}\text { (Elymus innovatus) } \\ \text { ROUGH FESCUE }\end{array} & 10 & 0-26 & 91 \\ \begin{array}{l}\text { (Festuca scabrella) } \\ \text { SLENDER WHEATGRASS } \\ \text { (Agropyron trachycaulum)5 }\end{array} & 3 & 0-13 & 55 \\ \begin{array}{l}\text { IDAHO FESCUE } \\ \text { (Festuca idahoensis) }\end{array} & 1 & 0-7 & 64 \\ \begin{array}{l}\text { BLUNT SEDGE } \\ \text { (Carex obtusata) }\end{array} & 14 & 0-31 & 55\end{array}$

MOISTURE REGIME:

SUBMESIC

NUTRIENT REGIME:

SUBMESOTROPHIC

ELEVATION:

1768-1981(1823) M

SOIL DRAINAGE:

WELL

SLOPE:

$$
0-35(12) \%
$$

ASPECT:

\section{SOUTHERLY}

\section{Forage Production Kg/HA}

$$
\begin{array}{ll}
\text { GrASS } & 814(163-1364) \\
\text { FORB } & 505(97-140) \\
\text { SHRUB } & 514(0-1743) \\
\text { TOTAL } & 1674(1000-2318)
\end{array}
$$

\section{SugGeSTED GRAZING CAPACITY}

$0.5 \mathrm{HA} / \mathrm{AUM}$ 


\section{SASMA5. Kentucky bluegrass/Dandelion (Poa pratensis/Taraxacum officinale)}

$\mathbf{n}=14$ This community type represents a moist, tufted hairgrass-sedge dominated community type that has been heavily grazed. Heavy grazing pressure causes tufted hairgrass to decline and allows sedge and Kentucky bluegrass to increase. Continuous heavy grazing pressure will eventually cause all native species to decline on the site and the site will become dominated by Kentucky bluegrass, dandelion and clover (Willoughby 1992).

Plant Composition Canopy Cover(\%) MEAN RANGe CONST.

SHRUBS

SMOOTH WILLOW

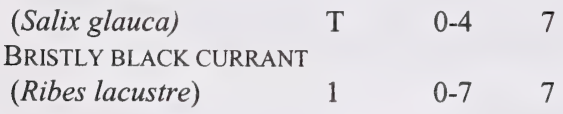

FORBS

DANDELION

$\begin{array}{llll}\text { (Taraxacum officinale) } & 10 & 1-29 & 100\end{array}$

YARROW

$\begin{array}{llll}\text { (Achillea millefolium) } & 5 & 2-15 & 100\end{array}$

FIREWEED

(Epilobium angustifolium) 3

BUNCHBERRY

$\begin{array}{llll}\text { (Cornus canadensis) } & 1 & 0-7 & 7\end{array}$

ClOVER

(Trifolium spp.)

$4 \quad 0-15 \quad 46$

GRASSES

KENTUCKY BLUEGRASS

$\begin{array}{lccc}\begin{array}{l}\text { (Poa pratensis) } \\ \begin{array}{l}\text { RUSH LIKE SEDGE } \\ \text { (Carex scirpoidea) }\end{array}\end{array} & 43 & 0-58 & 71 \\ \begin{array}{l}\text { TUFTED HAIRGRASS } \\ \text { (Deschampsia cespitosum) T }\end{array} & 0-5 & 7 \\ \begin{array}{l}\text { TIMOTHY } \\ \text { (Phleum pratense) }\end{array} & 12 & 0-28 & 71\end{array}$

\section{ENVIRONMENTAL VARIABLES}

MOISTURE REGIME:

SUBHYGRIC

NUTRIENT REGIME:

PERMESOTROPHIC

ELEVATION:

1541(1340-1798)M

SOIL DRAINAGE:

MODERATELY WELL

SLOPE:

$$
6(0-20) \%
$$

ASPECT:

$$
\text { VARIABLE }
$$

\section{Forage Production Kg/HA}

$$
\begin{array}{ll}
\text { GRASS } & 1673(248-3700) \\
\text { FORB } & 593(420-889) \\
\text { SHRUB } & 75(0-198) \\
\text { TOTAL } & 2341(746-4589)
\end{array}
$$

\section{SugGested GRAZING CAPACITY} $0.4 \mathrm{HA} / \mathrm{AUM}$ 


\section{SASMA6. Yellow mountain avens \\ (Dryas drummondii)}

$\mathbf{n}=1 \quad$ This is similar to the community type described in the Central and Northern Rocky Mountain ecodistricts. Corns and Achuff (1982) described this community type on recent fluvial and glacialfluvial landforms with gentle slopes, where the soils are rapidly drained. Willoughby et al. (2003), described a yellow mountain avens community on dry, gravelly river flats with nutrient poor soils in the Montane subregion. They found this community type to be successionally immature and succession would be to a Balsam poplar dominated community type.

Plant Composition CANopy Cover(\%) MEAN RANGe CONST.

\section{SHRUBS}

SHRUBBY CINQUEFOIL

(Potentilla fruticosa)

100

FORBS

YELLOW DRYAD

(Dryas drummondii) $\quad 13 \quad$ - 100

LATE YELLOW LOCOWEED

(Oxytropis monticola)

SILVERY CINQUEFOIL

(Potentilla argentea) $\quad 3 \quad-\quad 100$

LOW GOLDENROD

(Solidago missouriensis) $3 \quad$ - 100

YELLOW HEDYSARUM

(Hedysarum sulphurscens) 3

Grasses

HAIRY WILDRYE

(Elymus innovatus) $6 \quad-\quad 100$

JUNEGRASS

(Koeleria macrantha) $\quad$ T $\quad$ - $\quad 100$

SLENDER WHEATGRASS

(Agropyron trachycaulum) 1

BLUNT SEDGE

(Carex obtusata)

FRINGED BROME

(Bromus ciliatus)

100

100

$67 \quad-\quad 100$

100

\section{ENVIRONMENTAL VARIABLES}

MOISTURE REGIME:

MESIC

NUTRIENT REGIME:

SUBMESOTROPHIC

ELEVATION:

$2165 \mathrm{M}$

SOIL DRAINAGE:

WELL TO RAPIDLY

\section{Forage Production Kg/HA}

\author{
GRASS 572 \\ FORB 602 \\ TOTAL 1372 \\ *Estimate
}

SUGGESTED GRAZING CAPACITY NON-USE 


\section{SASMA7. Tufted hairgrass-Sedge \\ (Deschampsia cespitosa-Carex spp.)}

$\mathbf{n}=\mathbf{3}$ This community type was described in the Savanna Creek range allotment and is located on moist sites that are better drained and slightly drier than the pure sedge meadows. Willoughby(2001), found that tufted hairgrass is a common plant species on lowland sites in the valley bottoms of the Upper Foothills subregion. Willoughby (1992), found when this community type is protected from grazing for 25-30 years, willow and bog birch expand and tufted hairgrass and sedge decline. The decline in graminoid cover also results in a decline in available forage production . Continuous heavy grazing causes hairgrass to decline and the site will be invaded by Kentucky bluegrass and dandelion.

Plant Composition Canopy Cover(\%) MEAN Range CONST.

SHRUBS

BARCLAY'S WILLOW

(Salix barclayi)

(Potentilla fruticosa)

$\begin{array}{lll}3 & 0-7 & 33 \\ 1 & 0-2 & 33\end{array}$

FORBS

LINDLEY'S ASTER

(Aster ciliolatus)

$1 \quad 0-2 \quad 33$

YELLOW HEDYSARUM

(Hedysarum sulphurscens) 1

YARROW

(Achillea millefolium)

GRACEFUl CINQUEFOIL

(Potentilla gracilis)

OLD MAN'S WHISKERS

(Geum triflorum)

AMERICAN VETCH

(Vicia americana)

$\mathrm{T}$

GRASSES

TWO-SEEDED SEDGE

(Carex disperma)

$14 \quad 0-42 \quad 33$

TUFTED HAIRGRASS

(Deschampsia cespitosa) $41 \quad 18-62 \quad 100$

SLENDER WHEATGRASS

(Agropyron trachycaulum)

ROUGH FESCUE

(Festuca scabrella)

HAIRY WILDRYE

(Elymus innovatus)

6

$0-3 \quad 33$

$3-10 \quad 100$

6-14 100

$0-9 \quad 68$

67

$1-4 \quad 100$

$0-6 \quad 33$

$0-18 \quad 33$

\section{ENVIRONMENTAL VARIABLES}

\section{MOISTURE REGIME:}

SUBHYGRIC

NUTRIENT REGIME:

PERMESOTROPHIC

ELEVATION:

1445(1445-1450)M

SOIL DRAINAGE： MOD. WELL

SLPOE $4 \%$

ASPECT:NORTHERLY

FORAGE PRODUCTION KG/HA

$\begin{array}{ll}\text { GRASS } & 1164 \\ \text { FORBS } & 162 \\ \text { SHRUBS } & 0 \\ \text { TOTAL } & 1326\end{array}$

\section{SugGESTED GRAZING CAPACITY}

$0.7 \mathrm{HA} / A U M$ OR $2.5 \mathrm{AC} / \mathrm{AUM}$ 


\section{SASMA7a. Marsh reedgrass/Cow parsnip \\ (Calamagrostis canadensis/Heracleum lanatum.)}

$\mathbf{n}=\mathbf{1} \quad$ This community type represents moist seepage areas in the foothills west of Turner valley. Often these sites are willow dominated to form the Willow/Marsh reedgrass dominated community type. Marsh reedgrass is characteristic of the lower elevation Lower Foothills subregion. Moving up in elevation into the Subalpine and Upper Foothills subregions, there is often a shift in dominance away from marsh reedgrass to tufted hairgrass on these moist sites. This community type is very similar to the Cow parsnip/Veiny meadow rue community described by Lane et al. (2000) in the Lower Foothills subregion. In the Lower Foothills this community type is very productive and is often heavily utilized by livestock. The Marsh reedgrass-Timothy/Cow parsnip (SASMC8) represents a grazing disclimax of this community type.

\section{Plant Composition Canopy Cover(\%)}

\section{MEAN RANGe CONST.}

\section{SHRUBS}

PRICKLY ROSE

(Rosa acicularis)

RASPBERRY

(Rubus idaeus)

$$
4
$$

\section{FORBS}

COW PARSNIP

(Heracleum lanatum) $\quad 3 \quad-\quad 100$

FIREWEED

(Epilobium angustifolium) 25

WESTERN MEADOW RUE

(Thalictrum occidentalis) $10 \quad$ - $\quad 100$

HORSETAIL

(Equisetum arvense) $\quad 4 \quad$ - $\quad 100$

STICKY PURPLE GERANIUM

(Geranium viscosissimum) 4

AMERICAN VETCH

(Vicia americana)

\section{2}

Grasses

SEDGE

(Carex spp)

15

MARSH REEDGRASS

(Calamagrostis canadensis) 24

SLENDER WHEATGRASS

(Agropyron trachycaulum) $1 \quad$ - 100

IDAHO FESCUE

(Festuca idahoensis) 5

\section{ENVIRONMENTAL VARIABLES}

\section{MOISTURE REGIME:}

SUBHYGRIC

NUTRIENT REGIME:

PERMESOTROPHIC

\section{ELEVATION:}

$1768 \mathrm{M}$

SoIl Drainage: MoD. Well

SLOPE $3 \%$

ASPECT: SOUTHERLY

Forage Production KG/Ha

TOTAL 2000* ESTIMATE

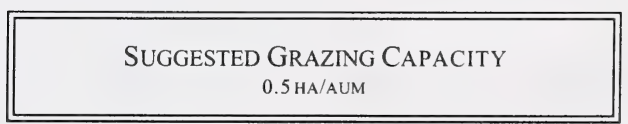




\section{SASMA8. Rough fescue-Idaho fescue-Parry oatgrass \\ (Festuca scabrella-Festuca idahoensis-Danthonia parryii)}

$\mathbf{n}=4 \quad$ This community was described on lower slope positions in the Castle area. It is very similar to the Rough fescue-Idaho fescue-Parry oatgrass community described on Black Chernozemic soils in the Montane subregion from an elevation of $1300 \mathrm{~m}$ up to $1900 \mathrm{~m}$ (Willoughby et al. 2003) Willoughby (1992), described one Rough fescue-dominated site where the species composition had not changed in over 30 years, indicating this maybe the climax community type on river terraces and south facing slopes in the Montane subregion. Indeed Moss and Campbell (1947), found that rough fescue grows almost to the exclusion of other plants in the absence of disturbance. On rocky and gravelly slopes with shallow soils, rough fescue is replaced by Parry oatgrass and Idaho fescue. They also found Parry oatgrass and Idaho fescue increased and rough fescue declined with increased grazing pressure. Willoughby (1992), also described rough fescue and Idaho fescue dominated community types with little Parry oatgrass in the Castle area south of Blairmore. He also found that rose and shrubby cinquefoil tended to increase in cover at higher elevations in these grasslands.

\section{Plant CoMposition CANopy Cover(\%)} MEAN RANGE CONST.

SHRUBS

SHRUBBY CINQUEFOIL

(Potentilla fruticosa)

PRICKLY ROSE

(Rosa acicularis)

$4 \quad 1-10 \quad 100$

$3 \quad 0-8 \quad 75$

FORBS

SHOWY ASTER

(Aster conspicuus)

8

0-29

75

COMMON FIREWEED

(Epilobium angustifolium) 4

CUT-LEAVED ANEMONE

(Anemone multifida)

GRACEFUL CINQUEFOIL

(Potentilla gracilis)

LONG-FRUITED WILD PARSLEY

(Lomatium macrocarpum) 1

LOW GOLDENROD

(Solidago missouriensis) 2

GRASSES

ROUGH FESCUE

\begin{tabular}{|c|c|c|c|}
\hline (Festuca scabrella) & 21 & $12-27$ & 10 \\
\hline IDAHO FESCUE & & & \\
\hline (Festuca idahoensis) & 7 & $0-13$ & 75 \\
\hline $\begin{array}{l}\text { PARRY OATGRASS } \\
\text { (Danthonia parrvi) }\end{array}$ & & & \\
\hline $\begin{array}{l}\text { (Danthonia parryi) } \\
\text { ?INE REED GRASS }\end{array}$ & 5 & $0-12$ & 50 \\
\hline $\begin{array}{l}\text { (Calamagrostis rubescens } \\
\text { HAIRY WILDRYE }\end{array}$ & & $0-15$ & 50 \\
\hline (Elymus innovatus) & 1 & $0-1$ & 50 \\
\hline
\end{tabular}

\section{ENVIRONMENTAL VARIABLES}

MOISTURE REGIME:

SUBXERIC TO SUBMESIC

NUTRIENT REGIME:

SUBMESOTROPHIC TO MESOTROPHIC

ELEVATION:

1838(1680-1974) M

SOIL DRAINAGE:

VERY RAPIDLY TO WELL

SLOPE: $13(6-22) \%$

ASPECT: VARIABLE

\section{Forage Production KG/HA}

GRASS 1146(934-1358)

FORBS 614(488-740)

SHRUBS 55(0-109)

TOTAL 1815(1674-1955)

\section{Suggested Grazing CAPACITY}

$0.5 \mathrm{HA} / \mathrm{AUM}$ 


\section{SASMA9. Rough fescue-Sedge/Bearberry \\ (Festuca scabrella-Carex obtusaia./Arctostaphylos uva-ursi)}

$\mathbf{n}=\mathbf{7} \quad$ This community is characteristic of dry, south facing slopes, below the crest of the hill. It appears that snow accumulates in these areas favoring the growth of rough fescue. This community is similar to the Rough fescueSedge/Bearberry community type described by Willoughby et al. (2003) on hilltops in the Montane subregion. The shallow poorly developed soils appear to favour rough fescue, slender wheatgrass, and sedge over Parry oatgrass. This community is drier than the Rough fescue-Idaho fescue-Parry oatgrass grasslands characteristic of lower slope positions. This community type is similar to the Sedge/Bearberry community type but lacks the high cover of rough fescue. It appears that the Sedge/Bearberry community may represent a grazing disclimax of this community type.

Plant Composition Canopy Cover(\%) Mean Range Const.

SHRUBS

SHRUBBY CINQUEFOIL

$\begin{array}{llll}\text { (Potentilla fruticosa) } & 5 & 1-11 & 100\end{array}$

PRICKLY ROSE

(Rosa acicularis)

$3 \quad 0-6 \quad 86$

FORBS

BEARBERRY

(Arctostaphylos uva-ursi) 40

SILKY PERENNIAL LUPIN

(Lupinus sericeus) $\quad 4 \quad 0-10 \quad 71$

CUT-LEAVED ANEMONE

(Anemone multifida) $3 \quad 0-2 \quad 71$

WILD STRAWBERRY

$\begin{array}{llll}\text { (Fragaria virginiana) } & 2 & 0-9 & 43\end{array}$

SMOOTH ASTER

$\begin{array}{llll}\text { (Aster laevis) } & 1 & 0-8 & 43\end{array}$

LOW GOLDENROD

(Solidago missouriensis)

Grasses

ROUGH FESCUE

(Festuca scabrella) $\quad 22 \quad 6-43 \quad 100$

SEDGES

(Carexspp.)

$2 \quad 0-5 \quad 71$

PARRYS OATGRASS

(Danthonia Perryi)

$4 \quad 0-18 \quad 43$

PINE REED GRASS

(Calamagrostis rubescens)4

HAIRY WILDRYE

(Elymus innovatus)

$0-15 \quad 50$

$0-9 \quad 57$

\section{ENVIRONMENTAL VARIABLES}

MOISTURE REGIME:

XERIC TO MESIC

NUTRIENT REGIME:

OLIGOTROPHIC TO MESOTROPHIC

ELEVATION:

1740(1400-1939)M

SOIL DRAINAGE:

VERY RAPIDLY-WELL

SLOPE:

$30(18-40) \%$

ASPECT:

VARIABLE

Forage Production KG/HA

GRASS 725(102-1612)

FORB 385(111-676)

SHRUB 1475(28-4400)

TOTAL 2585(970-5384)

SUGGESTED GRAZING CAPACITY

$0.3 \mathrm{HA} / \mathrm{AUM}$ 


\section{SASMA10. Parry oatgrass-Rough fescue-Sedge \\ (Danthonia parryi-Festuca scabrella-Carex spp)}

n=12 This community is situated upslope of the rough fescue dominated community types. This community type tends to be drier and better drained than the rough fescue dominated types found in the lower slope positions. The drier site conditions favour the growth of Parry oatgrass and sedge over rough fescue.

These sites are moderately productive and are easily accessible to livestock. They should be considered primary range. Continuous heavy grazing pressure will lead to a community type that is dominated by sedge and fringed sage.

Plant COMPOSITION G inopy Cover(\%)

MEAN KANGE CONST.

SHRUBS

SHRUBBY CINQUEFOIL

(Potentilla fruticosa)

PRICKLY ROSE

(Rosa acicularis) $\quad 3 \quad 0-5 \quad 75$

SASKATOON

(Amelanchier alnifolia)

2

$0-16 \quad 50$

FORBS

SILKY PERENNIAL LUPINE

(Lupinus sericeus)

CUT-LEAVED ANEMONE

(Anemone multifida)

OLD MAN'S WHISKERS

(Geum triflorum)

NORTHERN BEDSTRAW

(Galium boreale)

EARLY YELLOW LOCOWEED

(Oxytropis sericea)

GOLDENBEAN

(Thermophis rhombifolia)4

$5 \quad 0-18 \quad 75$

$2 \quad 0-2 \quad 83$

$2 \quad 0-21 \quad 42$

$\begin{array}{lll}4 & 1-8 & 100\end{array}$

$2 \quad 0-6 \quad 67$

$0-8 \quad 42$

Grasses

ROUGH FESCUE

$\begin{array}{llll}\text { (Festuca scabrella) } & 6 & 0-15 & 92\end{array}$

PARRY OATGRASS

(Danthonia parryi) $\quad 23 \quad 10-31 \quad 100$

SEDGES

(Carex spp.)

$3 \quad 0-8 \quad 94$

JUNE GRASS

(Koeleria macrantha)

COLUMBIA NEEDLE GRASS

(Stipa columbiana)

SLENDER WHEATGRASS

(Agropyron trachycaulum)

\section{ENVIRONMENTAL VARIABLES}

MOISTURE REGIME:

XERIC TO SUBXERIC

NUTRIENT REGIME :

OLIGOTROPHIC TO PERMESOTROPHIC

ELEVATION:

1473(1400-1962) M

SOIL DRAINAGE:

RAPIDLY TO WELL

SLOPE:

$$
23(12-33) \%
$$

ASPECT:

VARIABLE

\section{Forage Production Kg/HA}

GRASS 732(356-1284)

FORB 702(0-1550)

SHRUB $96(0-388)$

TOTAL 1452(660-2866)

\section{SUGGESTED GRAZING CAPACITY}

0.6 HA/AUM 


\section{SASMA11. Sedge/Bearberry \\ (Carex spp./Arctostaphylos uva-ursi)}

$\mathbf{n = 1 1}$ This community was described on south facing slopes. This community is very similar to the Rough fescue-

Sedge/Bearberry community type, but lacks the high cover of rough fescue. A number of the sites described in this community had extensive grazing pressure by bighorn sheep and domestic livestock. It is possible that this community type represents a grazing disclimax of the Rough fescue-Sedge/Bearberry community type.

\section{PLANT COMPOSITION CANOPY COVER(\%)} MEAN RANGe CONST.

\section{TREES}

SUBALPINE FIR

$\begin{array}{llll}\text { (Abies lasiocarpa) } & \text { T } & 0-2 & 20 \\ \text { WhITE BARK PINE } & & & \end{array}$

(Pinus albicaulis) $\quad$ T $\quad 0-3 \quad 20$

\section{SHRUBS}

BEARBERRY

(Arctostaphylos uva-ursi) $27 \quad 6-70 \quad 100$

SHRUBBY CINQUEFOIL

$\begin{array}{llll}\text { (Potentilla fruticosa) } & 2 & 0-8 & 70\end{array}$

SASKATOON

(Amelanchier alnifolia) $\quad 4 \quad 0-10 \quad 50$

\section{FORBS}

EARLY YELLOW LOCOWEED

(Oxytropis sericea) $2 \quad 0-5 \quad 90$

BROWN-BRACTED MOUNTAIN EVERLASTING

(Antennaria umbrinella) $1 \quad 0-5 \quad 50$

YELLOW VALSE DANDELION

(Agoseris glauca)

$0-3 \quad 70$

ARCTIC SANDWART

$\begin{array}{llll}\text { (Minuartia obtusiloba) } & 1 & 0-3 & 40\end{array}$

YELLOW HEDYSARUM

(Hedysarum sulphurescens) $2 \quad 0-6 \quad 60$

COMMON FIREWEED

(Epilobium angustifolium) $1 \quad 0-3 \quad 30$

\section{GRASSES}

\section{SEDGES}

$\begin{array}{llll}\text { (Carexspp.) } & 1 & 0-4 & 80\end{array}$

ROUGH FESCUE

$\begin{array}{llll}\text { (Festuca scabrella) } & 2 & 0-7 & 70\end{array}$

IDAHO FESCUE

(Festuca idahoensis) $\quad 1 \quad 0-2 \quad 80$

BLUEBUNCH WHEATGRASS

(Agropyron spicatum)

\section{ENVIRONMENTAL VARIABLES}

MOISTURE REGIME:

XERIC-SUBXERIC

NUTRIENT REGIME:

OLIGOTROPHIC TO PERMESOTROPHIC

ELEVATION:

1883(1706-2072)M

SOIL DRAINAGE:

VERY RAPIDLY TO WELL

SLOPE: $\quad 31(16-50) \%$

ASPECT: SOUTH TO WEST

\section{Forage Production Kg/HA}

GRASS 733(17-1238)

FORB 391(34-583)

SHRUB 1051(241-2382)

TOTAL 2175(605-4121)

SugGESTED GRAZING CAPACITY NON-USE 


\section{SASMA12. Silverberry-Rose \\ (Elaeagnus commutata-Rosa acicularis)}

$\mathbf{n}=\mathbf{1}$ This community type was described on the downwind side of the hill at lower elevations in the Castle area of the province (north of Waterton Lakes National Park). It appears this area accumulates snow so the moisture regime is favorable for the growth of silverberry and aspen. At $1800 \mathrm{~m}$ aspen is at its upper elevational limit. The aspen trees at this site are very stunted and lack the vigour of lower elevation sites. Silverberry is well adapted to growing on dry, gravelly, light soils in ravines, coulees and stream banks throughout Alberta (Wilkinson 1990). It is unusual to have silverberry and aspen growing at these higher elevations indicating that this site is somewhat protected and warmer so that the climate resembles the lower elevation sites.

\section{Plant COMPOSITION CANopy Cover(\%) Mean Range Const.}

TREES

ASPEN

(Populus tremuloides)

4

100

\section{SHRUBS}

SILVERBERRY

(Elaeagnus commutata) 15

PRICKLY ROSE

(Rosa acicularis) $\quad 5$

ASPEN

(Populus tremuloides)

\section{FORBS}

MOUSE EARED CHICKWEED

(Cerastium arvense) 6

FALSE DANDELION

(Agoseris glauca)

2

SILVER PLANT

(Eriogonum ovalifolium) $\mathrm{T}$

GRASSES

ROCKY MOUNTAIN FESCUE

(Festuca brachycaulum) 1

BLUEBUNCH WHEATGRASS

(Agropyron spicatum) 3

100

\section{ENVIRONMENTAL VARIABLES}

MOISTURE REGIME:

XERIC

NUTRIENT REGIME:

SUBMESOTROPHIC

ELEVATION: $\quad 1841 \mathrm{M}$

SOIL DRAINAGE: VERY RAPIDLY

SLOPE: $24 \%$

ASPECT: SOUTHEASTERLY

Forage Production Kg/HA

TOTAL $500 *$ EsTIMATE

SUGGESTED GRAZING CAPACITY

$1.8 \mathrm{HA} / \mathrm{AUM}$ 


\section{SASMA13. Fescue-Junegrass/Early yellow locoweed (Festuca spp.-Koeleria macrantha/Oxytropis sericea)}

$\mathbf{n}=17$ This community type is characteristic of the dry, rocky, windswept ridges in the Castle area north of Waterton Lakes National Park. At higher elevations this community is often replaced by the White mountian avens community which occupies similar sites. This community type is somewhat variable false mountain dandelion and early yellow locoweed were found in the majority of the plots, but in areas where there is slightly more snow accumulation the cover of Idaho fescue increases, and there are larger patches of species like spotted saxifrage, brown bracted mountian everlasting and sandwort. Bareground on these moister areas is usually less than $40 \%$. In contrast bareground on the drier parts of this community type exceed $60 \%$. At lower elevations on Whistler Mtn. bluebunch wheatgrass becomes more prevalent.

Plant Composition Canopy Cover(\%) Mean Range Const.

\section{SHRUBS}

SHRUBBY CINQUEFOIL

$\begin{array}{llll}\begin{array}{l}\text { (Potentilla fruticosa) } \\ \text { LIMBER PINE }\end{array} & 3 & 0-13 & 82 \\ \text { (Pinus flexilis) } & 1 & 0-11 & 12\end{array}$

(Pinus flexilis)

FORBS

BEARBERRY

(Arctostaphylos uva-ursi) 1

KITTENTAILS

(Besseya wyomingensis) 1

EARLY YELLOW LOCOWEED

(Oxytropis sericea) 1

SANDWORT

(Minuartia obtusiloba)

LITTLE CLUBMOSS

(Selaginella densa)

SPOTTED SAXIFRAGE

(Saxifraga bronchialis) 3

GRASSES

ROUGH FESCUE

(Festuca scabrella) $\quad 1 \quad 0-6 \quad 24$

JUNEGRASS

(Koeleria macrantha) $2 \quad 0-5 \quad 77$

SEDGE

(Carex spp.)

$0-8 \quad 24$

$0-3 \quad 59$

$0-5 \quad 88$

$0-16 \quad 47$

$0-8 \quad 41$

$0-29 \quad 24$

IDAHO FESCUE

(Festuca idahoensis)

SMOOTH BROME

(Bromus pumpellianus)

BLUEBUNCH WHEATGRASS

(Agropyron spicatum) 1

\section{ENVIRONMENTAL VARIABLES}

MOISTURE REGIME:

VERY XERIC TO SUBXERIC

NUTRIENT REGIME:

OLIGOTROPHIC TO MESOTROPHIC

ELEVATION:

1949(1536-2322) M

SOIL DRAINAGE:

VERY RAPIDLY TO WELL

SLOPE: $\quad 26(6-50) \%$

ASPECT: VARIABLE

Forage Production Kg/HA

GRASS 512(18-2018)

FORB 291(44-680)

SHRUB 192(0-589)

TOTAL 994(519-2126)

Suggested GraZING CAPACITY NON-USE 


\section{SASMA14. White mountain avens}

(Dryas octopetala)

n=12 This community occurs on wind-exposed, snow free ridges and resembles the White mountain avens community described in the Alpine subregion. The soils are shallow, stoney, colluvial Regosols (Corns and Achuff 1982). Ogilvie (1969), found this community type to have an abundance of cushion and mat plants and a large number of lichens. This community is generally found at higher elevations than the Fescue-Junegrass/E. yellow locoweed community type. This community type appears to have no snow accumulation throughout the year, whereas, the fescue, Junegrass dominated community appears to have some snow accumulation. This may account for the differences in dominant plant species for each community type.

\section{Plant Composition CANopy Cover(\%)}

MEAN RANGe CONST.

\section{SHRUBS}

PRICKLY ROSE

$\begin{array}{llll}\text { (Rosa acicularis) } & \text { T } & 0 & 25\end{array}$

SHRUBBY CINQUEFOIL

(Potentilla fruticosa) $2 \quad 0-6 \quad 92$

BUFFALOBERRY

$\begin{array}{llll}\text { (Shepherdia canadensis) } & \text { T } & 0-3 & 8\end{array}$

SILVERBERRY

$\begin{array}{llll}\text { (Elaeagnus commutata) } & \mathrm{T} & 0-2 & 8\end{array}$

\section{FORBS}

WHITE MOUNTAIN AVENS

(Dryas octopetala)

EARLY YELLOW LOCOWEED

(Oxytropis sericea) 3

SPOTTED SAXIFRAGE

(Saxifraga bronchialis)

KITTENTAILS

(Besseya wyomingensis) 1

YELLOW HEDYSARUM

(Hedysarum sulphurscens)2

FALSE MTN. DANDELION

(Agoseris glauca)

1

\section{GRASSES}

IDAHO FESCUE

(Festuca idahoensis) $\quad 1 \quad 0-4 \quad 33$

SEDGE SPP.

(Carex spp.)

SMOOTH BROME

(Bromus pumpellianus) $1 \quad 0-2 \quad 67$

JUNEGRASS

(Koeleria macrantha) $\quad 1 \quad 0-5 \quad 67$

\section{ENVIRONMENTAL VARIABLES}

\section{MOISTURE REGIME:}

VERY XERIC-SUBXERIC

NUTRIENT REGIME:

OLIGOTROPHIC TO SUBMESOTROPHIC

ELEVATION:

2136(2001-2423) M

SOIL DRAINAGE:

VERY RAPIDLY TO RAPIDLY

SLOPE : $17(7-38) \%$

ASPECT: VARIABLE

\section{Forage Production KG/HA}

$\begin{array}{ll}\text { GRASS } & 36(25-47) \\ \text { FORB } & 198(27-369) \\ \text { SHRUB } & 392(195-589) \\ \text { TOTAL } & 626(269-983)\end{array}$

Suggested Grazing CAPACTIY NON-USE 


\section{SASMA15. Pinegrass-Hairy wildrye/Strawberry \\ (Calamagrostis rubescens-Elymus innovatus/Fragaria virginiana)}

$\mathbf{n}=4$ This community type is similar to the pinegrass dominated community type described on west and north facing slopes in the Montane subregion (Willoughby et al 2003). In the Montane this community represents the transition from grassland to forest on moist sites with northerly aspects. There is usually high forb cover on these sites with strawberry, showy aster, american vetch and silkly perennial lupine being common. Pinegrass and Hairy wildrye are common grass species in the understory of conifer and deciduous stands and their dominance in this community type may indicate a transition to a forested community. The higher moisture conditions on these sites allows for production of over $2000 \mathrm{~kg} / \mathrm{ha}$.

\section{Plant Composition Canopy Cover(\%)}

\section{SHRUBS}

PRICKLY ROSE

(Rosa acicularis)

MEAN RANGE CONST.

SHRUBBY CINQUEFOIL

(Potentilla fruticosa)

WHITE MEADOWSWEET

$\begin{array}{llll}\text { (Spiraea betulifolia) } & 1 & 0-4 & 25\end{array}$

ASPEN

(Populus tremuloides)

$0-3 \quad 50$

\section{FORBS}

SILKY PERENNIAL LUPINE

(Lupinus sericeus) 4

SHOWY ASTER

(Aster conspicuus)

COMMON DANDELION

(Taraxacum officinale) 3

CREAM-COLORED VETCHILING

(Lathyrus ochroleucus)

GRACEFUL CINQUEFOIL

(Potentilla gracilis)

FALSE MTN. DANDELION

(Agoseris glauca)

$\begin{array}{lll}9 & 1-20 & 100 \\ 1 & 1-2 & 100 \\ 1 & 0-4 & 25\end{array}$

GraSSES

PINEGRASS

(Calamagrostis rubescens) $11 \quad 1-22 \quad 100$
JUNEGRASS

(Koeleria macrantha) $\quad 2 \quad 1-2 \quad 100$

HAIRY WILDRYE

(Elymus innovatus) $\quad 4 \quad 0-11 \quad 75$

KENTUCKY BLUEGRASS

(Poa pratensis)

$3 \quad 0-13 \quad 25$

\section{ENVIRONMENTAL VARIABLES}

MOISTURE REGIME:

SUBXERIC TO MESIC

NUTRIENT REGIME:

SUBMESOTROPHIC TO MESOTROPHIC

ELEVATION:

1701(1684-1710)M

SOIL DRAINAGE:

WELL TO IMPERFECTLY

SLOPE (RANGE):

$31(23-40) \%$

ASPECT:

SOUTHERLY

\section{Forage ProduCtion KG/HA}

GRASS 758(392-1204)

FORB 1170(506-1884)

SHRUB $110(0-260)$

TOTAL 2037(1346-2739)

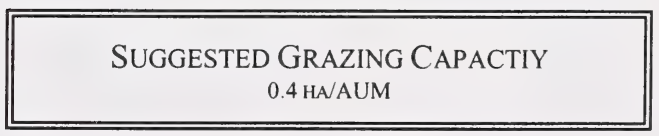




\section{SASMA16. Forb meadow (Epilobium angustifolium)}

$\mathbf{n}=\mathbf{3}$ This site is similar to the Fireweed-Meadow rue/Sedge dominated community type described in the northern foothills area of the Subalpine. This community is characterized by a dominance of forb species (fireweed, graceful cinquefoil, yellow hedysarum) and only a small cover of grass species. It would appear that the moisture and nutrient regime are higher on this site compared to the other grassland community types which favors the growth of forb species. Succession in the absence of disturbance will likely be to aspen and then white spruce.

The forage production of this community type is fairly high because of the higher moisture and nutrient content of the soil, but the areas are so small and isolated they contribute little to the overall carrying capacity of a disposition.

\section{Plant Composition Canopy Cover(\%)}

SHRUBS

PRICKLY ROSE

(Rosa acicularis)

SHRUBBY CINQUEFOIL

(Potentilla fruticosa)

CREEPING JUNIPER

(Juniperus horizontalis)

2

$0-2 \quad 100$

$3 \quad 0-5 \quad 100$

$1 \quad 0-2 \quad 67$

\section{MEAN RANGe CONST.}

\section{FORBS}

GRACEFUL CINQUEFOIL

(Potentilla gracilis)

COMMON FIREWEED

(Epilobium angustifolium)6

YELLOWHEDYSARUM

(Hedysarum sulphurescens) 4
WILD VETCH

(Vicia americana)

WILD STRAWBERRY

(Fragaria virginiana)

(Anemone multifida)

2

$3 \quad 1-6 \quad 100$

2-10 $\quad 100$

$0-9 \quad 100$

$0-3 \quad 100$

$1 \quad 0-1 \quad 100$

$1 \quad 0-2 \quad 100$

\section{GRASSES}

HAIRY WILDRYE

$\begin{array}{llll}\begin{array}{l}\text { (Elymus innovatus) } \\ \text { PARRYS OATGRASS } \\ \text { (Danthonia parryi) }\end{array} & 3 & 0-5 & 100 \\ \begin{array}{l}\text { TIMOTHY } \\ \text { (Phleum pratense) }\end{array} & 1 & 0-1 & 67 \\ \begin{array}{l}\text { ROUGH FESCUE } \\ \text { (Festuca scabrella) }\end{array} & 2 & 0-4 & 33\end{array}$

\section{ENVIRONMENTAL VARIABLES}

MOISTURE REGIME:

MESIC

NUTRIENT REGIME:

PERMESOTROPHIC TO MESOTROPHIC

ELEVATION: $1701(1684-1710)$

SOIL DRAINAGE:

WELL TO IMPERFECTLY

SLOPE: $3(0-7) \%$

ASPECT: VARIABLE

Forage Production KG/Ha

GRASS 554(175-1126)

FORB 734(567-1009)

SHRUB $125(0-208)$

TOTAL 1413(968-2135)
Suggested Grazing CAPACTIY

$0.6 \mathrm{HA} / \mathrm{AUM}$ 


\section{SASMB1. Willow/Sedge \\ (Salix spp./Carex spp.)}

$\mathbf{n}=\mathbf{2}$ Willow encroachment into moist grassland meadows eventually results in this community type Historically fire has played an important role in the maintenance of the grassland community type in this subregion. Continued fire suppression will eventually allow willow and bog birch to invade many of the grassy meadows.

This community type is slightly drier than the Willow/Water sedge dominated community type.

\section{Plant Composition Canopy Cover(\%)} MEAN RANGe CONST.

SHRUBS

WILLOW

(Salix spp.)

$30 \quad 27-32 \quad 100$

BOG BIRCH

(Betula glandulosa)

SHRUBBY CINQUEFOIL

(Potentilla fruticosa)

4

$3 \quad 0-5 \quad 100$

\section{FORBS}

YARROW

(Achillea millefolium)
WILD STRAWBERRY

(Fragaria virginiana)

SMOOTH ASTER

(Aster laevis)

SILVERY CINQUEFOIL

(Potentilla argentea)

LOW GOLDENROD

(Solidago missouriensis) 8

GRASSES

TUFTED HAIRGRASS

(Deschampsia cespitosa)

BALTIC RUSH

(Juncus balticus)

SEDGE

(Carex spp.)

HAIRY WILDRYE

(Elymus innovatus)

$1 \quad 0-1 \quad 50$

$7 \quad 0-13 \quad 50$

$3 \quad 0-6 \quad 50$

$3 \quad 0-6 \quad 50$

$0-15 \quad 50$

\section{ENVIRONMENTAL VARIABLES}

MOISTURE REGIME:

MESIC -HYGRIC

NUTRIENT REGIME :

OLIGOTROPIC TO PERMESOTROPHIC

ELEVATION:

$1599(1300-1631) \mathrm{M}$

SOIL DRAINAGE :

WELL TO VERY POORLY

\section{Forage Production Kg/HA}

GRASS $1695(1622-1768)$

FORB 373(0-1120)

SHRUB $149(0-446)$

TOTAL 2478(2068-2888)

\section{SUGGESTED GRAZING CAPACITY \\ NON-USE}




\section{SASMB2. Willow/Richardson needlegrass (Salix spp./Stipa richardsonii)}

$\mathbf{n}=\mathbf{2}$ The ecology of this community type is unclear. Stringer (1973) described a Richardson needlegrass shrub savanna on small isolated areas, south facing slopes amongst subalpine fir, spruce, douglas fir forests in Banff and Jasper National Parks. He felt these grassland types were not closely related to any other grassland types.

\section{Plant Composition Canopy Cover(\%)} Mean Range CONST.

\section{SHRUBS}

WILLOW SPP.

(Salix myrtillfolia) $\quad 30 \quad 20-40 \quad 100$

BOG BIRCH

\section{(Betula glandulosa)}

SHRUBBY CINQUEFOIL

(Potentilla fruticosa)

$$
5
$$$$
0-10
$$

$5 \quad 0-10 \quad 50$

\section{FORBS}

SHOWY LOCOWEED

(Oxytropis splendens)

YARROW

(Achillea millefolium)

FIREWEED

(Epilobium angustifolium) 1

STRAWBERRY

(Fragaria virginiana)

2

1

100

1.100

$1-2 \quad 100$

\section{ENVIRONMENTAL VARIABLES}

MOISTURE REGIME:

SUBMESIC

NUTRIENT REGIME:

MESOTROPHIC

ELEVATION:

1375(1300-1450) M

SOIL DRAINAGE:

WELL

FORAGE CAPACITY KG/HA

\section{GRASSES}

RICHARDSON NEEDLEGRASS

(Stipa richardsonii) 45

ROCKY MTN. FESCUE

$40-50 \quad 100$

(Festuca saximontana) 8

$5-10 \quad 100$

SEDGE

(Carex spp)

$1-5 \quad 100$

QUACK GRASS

$3 \quad 1-5 \quad 100$

(Agropyron repens)

$0-2 \quad 50$

\section{SUGGESTED GRAZING CAPACITY}

NON-USE 


\section{SASMB3. Whitebark pine \\ (Pinus albicaulis)}

$\mathrm{n}=\mathbf{1} \quad$ This is a timberline community type found on steep south facing slopes with subxeric moisture regimes. The trees tend to be very small and shrub like. On moister sites the tree islands would by made up of the subalpine fir community type previously described.

\section{Plant COMPOSITION CANOPY COVER(\%)} Mean Range Const.

\section{TREES}

WHITE BARK PINE

(Pinus albicaulis)

$25 \quad-\quad 100$

\section{SHRUBS}

SMOOTH WILLOW

(Salix glauca)

BUFFALOBERRY

(Shepherdia canadensis) 8

GROUND JUNIPER

(Juniperus communis)

$-\quad 100$

$3 \quad-\quad 100$

FORBS

BEARBERRY

(Arctostaphylos uva-ursi) 2

MOUNTAIN GOLDENROD

(Solidago spathulata) 2

STRAWBERRY

$\begin{array}{llll}\text { (Fragaria virginiana) } & 2 & - & 100\end{array}$

YARROW

(Achillea millefolium)

\section{GRASSES}

SMOOTH BROME

(Bromus inermis)

SEDGE

(Carex spp.)

HAIRY WILDRYE

(Elymus innovatus)

\section{ENVIRONMENTAL VARIABLES}

MOISTURE REGIME:

SUBXERIC

NUTRIENT REGIME :

MESOTROPHIC

ELEVATION:

$2030 \mathrm{M}$

SOIL DRAINAGE:

RAPIDLY

SLOPE:

$60 \%$

ASPECT:

SOUTHERLY

Forage CAPACITY KG/HA

100

\section{SUGGESTED GRAZING CAPACITY}

NON-USE 


\section{SASMB4. Willow-Bog birch/Rough fescue-Kentucky bluegrass \\ (Salix spp.-Betula glandulosa $\mid$ Festuca scabrella-Poa pratensis)}

$\mathbf{n}=\mathbf{1} \quad$ This community type represents the inside transect of a rangeland reference area which has been protected from grazing for over 30 years. This community type represents moist meadows and grasslands in the Sheep area west of Turner valley. Continous heavy grazing pressure will cause the cover of shrubs and rough fescue to decline and allow Kentucky bluegrass, timothy and dandelion to invade onto the site.

This area of the province is classified as Lower Foothills (Alberta Environmental Protection 1994), but the plant species of this area are more characteristic of the Parkland and Montane subregions and the higher Subalpine subregion than the Lower Foothills. As a result this community type was placed within the Subalpine subregion guide.

\section{PLANT COMPOSITION CANOPY COVER(\%)} MEAN RANGe CONST.

\section{SHRUBS}

PUSSY WILLOW

(Salix discolor)

BOG BIRCH

(Betula glandulosa)

SHRUBBY CINQUEFOIL

(Potentilla fruticosa)

$$
14
$$

11

100

$5 \quad-\quad 100$

FORBS

LINDLEY'S ASTER

(Aster ciliolatus)

WOOLLY CINQUEFOIL

(Potentilla hippiana)

STRAWBERRY

(Fragaria virginiana)

YARROW

(Achillea millefolium)

FIREWEED

(Epilobium angustifolium) 3

VEINY MEADOW RUE

(Thalictrum venulosum) 3

7

6

2

3

GRASSES

SMOOTH BROME

(Bromus inermis)

SEDGE

(Carex spp.)

HAIRY WILDRYE

(Elymus innovatus)

\section{2}

1

1
100

100

100

100
MOISTURE REGIME:
SUBHYGRIC

NUTRIENT REGIME :

PERMESOTROPHIC

ELEVATION:

$1450 \mathrm{M}$

SOIL DRAINAGE:

MOD. WELL

SLOPE: $2 \%$

ASPECT: SOUTHERLY

\section{Forage Production Kg/HA}

$\begin{array}{ll}\text { GRASS } & 600 \\ \text { FORB } & 200 \\ \text { SHRUB } & 150 \\ \text { TOTAL } & 950 * \text { ESTIMATE }\end{array}$

\section{SUGGESTED GRAZING CAPACITY}

1.1 HA/AUM OR $2.5 \mathrm{AC} / \mathrm{AUM}$

\section{ENVIRONMENTAL VARIABLES}




\section{SASMB5. Willow/Marsh reedgrass \\ (Salix spp./Calamagrostis canadensis)}

$\mathbf{n}=\mathbf{2}$ This community type was described in the Pekisko and Deep Creek allotments which are southwest of Longview. This community represents a small pocket of willow in depressional and seepage areas. It is unusual having a community type dominated by marsh reedgrass in the Subalpine subregion. Marsh reedgrass is more characteristic of wetland sites in the Boreal forest and Lower Foothills subregions of North and Central Alberta. Perhaps this community represents a transition between the Subalpine and lower elevation Montane subregion.

These sites can be highly productive because of the increased moisture and nutrients at the site, but livestock will rarely use these communities and they should be considered non-use.

\section{PlaNT COMPOSITION CANOPY COVER(\%)} MEAN RANGe CONST.

SHRUBS

WILLOW

(Salix spp.)

BOG BIRCH

(Betula glandulosa)

ENGELMANN SPRUCE

(Picea engelmannii)

$$
19
$$$$
13-25 \quad 100
$$

$2 \quad 0-3 \quad 50$

$8 \quad 0-15 \quad 50$

\section{FORBS}

ARROW-LEAVED COLTSFOOT

\section{(Petasites sagittatus) 4}

COMMON HORSETAIL

(Equisetum arvense) 7

COW PARSNIP

(Heracleum lanatum) 14

FIREWEED

(Epilobium angustifolium) 8

TALL LARKSPUR

(Delphinium glaucum) 4

\section{GRASSES}

MARSH REEDGRASS

(Calamagrostis canadensis) $20 \quad 15-25 \quad 100$

Тімотну

$\begin{array}{llll}\text { (Phleum pratense) } & 2 & 1-3 & 100\end{array}$

SWEETGRASS

(Hierochloe odorata) $\quad 1 \quad 0-1 \quad 50$

\section{ENVIRONMENTAL VARIABLES}

MOISTURE REGIME :

SUBHYGRIC-HYGRIC

NUTRIENT REGIME:

PERMESOTROPHIC-EUTROPHIC

ELEVATION:

1704(1671-1737)M

SOIL DRAINAGE:

IMPERFECTLY

SLOPE:

$0 \%$

ASPECT:

NORTH

Forage Production KG/HA

TOTAL $3500 *$ EsTIMATE

\section{SUGGESTEDGRAZING CAPACITY}

NON-USE 


\section{SASMC1. Parry oatgrass-Rough fescue-Kentucky bluegrass}

(Danthonia parryii-Festuca scabrella-Poa pratensis)

$\mathbf{n}=\mathbf{7} \quad$ This community type represents the grazing disclimax community of the Rough fescue-Idaho fescue-Parry oatgrass community type. Increased grazing pressure favours the growth of Parry oatgrass and sedge over rough fescue. Continued heavy grazing pressure eventually leads to a decline in all native species and the site is often dominated by only Kentucky bluegrass, timothy and dandelion. Recovery of this community type back to a rough fescue dominated site is possible with a reduction in grazing pressure, but once Kentucky bluegrass establishes in the stand it will likely remain as a co-dominant.

This community type is very productive and should be considered primary range.

\section{Plant Composition Canopy Cover(\%)} Mean Range CONST.

SHRUBS

PRICKLY ROSE

(Rosa acicularis)

$1 \quad 0-1 \quad 57$

SASKATOON

(Amelanchier alnifolia) $\quad 1 \quad 0-1 \quad 14$

SHRUBBY CINQUEFOIL

(Potentilla fruticosa)

4

$0-9 \quad 86$

FORBS

YARROW

(Achillea millefolium)

WILD STRAWBERRY

$\begin{array}{llll}\text { (Fragaria virginiana) } & 1 & 0-6 & 72\end{array}$

THREE FLOWERED AVENS

(Geum triflorum)

GRACEFUL CINQUEFOIL

$\begin{array}{llll}\text { (Potentilla gracilis) } & 3 & 1-11 & 100\end{array}$

DANDELION

(Taraxacum officinale) $\quad 4 \quad 1-9 \quad 100$

AMERICAN VETCH

(Vicia americana)

$4 \quad 0-13 \quad 86$

GraSSES

PARRY OATGRASS

(Danthonia parryi) $\quad 17 \quad 6-25 \quad 100$

ROUGH FESCUE

$\begin{array}{llll}\text { (Festuca scabrella) } & 7 & 1-13 & 100\end{array}$

KENTUCKY BLUEGRASS

(Poa pratensis)

IDAHO FESCUE

(Festuca idahoensis)

Тімотну

(Phleum pratense)

\section{ENVIRONMENTAL VARIABLES}

MOISTURE REGIME :

XERIC TO SUBMESIC

NUTRIENT REGIME :

SUBMESOTROPHIC TO MESOTROPHIC

ELEVATION:

1488(1397-1510)M

SOIL DRAINAGE :

RAPIDLY TO WELL

SLOPE:

$$
16(0-50) \%
$$

ASPECT:

SOUTH EASTERLY

Forage Production KG/HA

GRASS 1160(654-1412)

FORB 712(382-1140)

SHRUB 39(0-118)

TOTAL 1574(660-2448)
SUGGESTED GRAZING CAPACITY

$0.6 \mathrm{HA} / \mathrm{AUM}$ 


\section{SASMC2. Parry oatgrass-Kentucky bluegrass-Sedge (Danthonia parryi-Poa pratensis-Carex spp.)}

$\mathbf{n}=4$ This community type represents a heavily grazed Parry oatgrass-Rough fescue-Sedge community type. Heavy grazing pressure favours the growth of grazing resistant species of Kentucky bluegrass and sedge and causes rough fescue to decline. Continued heavy grazing pressure will eventually lead to a community type that is dominated by Kentucky bluegrass, timothy and sedge. If the grazing pressure is reduced on this community type there is a good possibility of recovery.

\section{Plant Composition Canopy Cover(\%)}

\section{SHRUBS}

SHRUBBY CINQUEFOIL

(Potentilla fruticosa) $\quad 2 \quad 1-3 \quad 100$

SASKATOON

(Amelanchier alnifolia) $\quad 1 \quad 0-2 \quad 50$

\section{FORBS}

THREE FLOWERED AVENS

(Geum triflorum) 4

EARLY YELLOW LOCOWEED

(Oxytropis sericea) 6

SILKY PERENNIAL LUPINe

(Lupinus sericeus)

CUT-LEAVED ANEMONE

(Anemone multifida)

MEAN RANGe CONST.
$4 \quad 0-9 \quad 100$

$6 \quad 0-16 \quad 75$

$4 \quad 0-14 \quad 75$

$3 \quad 0-5 \quad 100$
GRASSES

PARRY OATGRASS

(Danthomia pargyi)

KENTUCKY BLUEGRAS

(Poa pratensis)

SEDGE

(Carex spp)

SLENDER WHEATGRASS

(Agropyron trachycaulum)

TIMOTHY

(Phleum pratense)

\section{ENVIRONMENTAL VARIABLES}

MOISTURE REGIME:

XeRIC TO SUBMESIC

NUTRIENT REGIME:

SUBMESOTROPHIC TO MESOTROPHIC

ELEVATION:

1419(1400-1441)M

SOIL DRAINAGE:

RAPIDLY

SLOPE:

$25(13-30) \%$

ASPECT:

SOUTHWESTERLY

Forage Production Kg/HA

GRASS 919(0-2018)

FORB 930(108-2330)

SHRUB 60(0-238)

TOTAL 1908(1408-2330)

\section{SUGGESTED GRAZING CAPACITY $0.5 \mathrm{HA} / \mathrm{AUM}$}




\section{SASMC3. Meadow foxtail-Kentucky bluegrass \\ (Alopecurus pratensis-Poa pratensis)}

$\mathbf{n}=\mathbf{3}$ This community type was described in the South Sheep allotment. It represents small aspen stands that were cleared and seeded to a mixture of meadow brome, creeping red fescue, clover and meadow foxtail. These sites have continued to be heavily grazed which has favoured the growth of meadow foxtail, Kentucky bluegrass and clover. Meadow foxtail is not particularly palatable to livestock and therefore gains a competitive advantage over meadow brome and creeping red fescue, in these seeded areas.

\section{PlantCOMPOSITIONCANopyCover(\%)} Mean Range Const.

SHRUBS

SHRUBBY CINQUEFOIL

(Potentilla fruticosa)

PRICKLY ROSE

(Rosa acicularis)

$\mathrm{T}$

$0-1$

$0-1$

33

\section{FORBS}

\section{COMMON DANDELION}

(Taraxacum officinale) 8
STICKY PURPLE GERANIUM

(Geranium viscosissimum) 1

ClOVER

\section{(Trifolium spp.) \\ WESTERN MEADOW RUE}

$11 \quad 0-32$

4-12 100

$0-2 \quad 100$

(Thalictrum occidentale) 3

\section{GRASSES}

MEADOW FOXTAIL

(Alopecurus pratensis) $\quad 23 \quad 14-33 \quad 100$

SEDGE

\section{(Carex spp.)}

KENTUCKY BLUEGRASS

(Poa pratensis)

TIMOTHY

(Phleum pratense)

RED FESCUE

(Festuca rubra)

$4 \quad 1-6 \quad 100$

$24 \quad 14-36 \quad 100$

$1 \quad 1-2 \quad 100$

$6 \quad 0-15 \quad 67$

\section{ENVIRONMENTAL VARIABLES}

MoISTURE REgIME:

MESIC TO SUBHYGRIC

NUTRIENT REGIME:

MESOTROPHIC TO PERMESOTROPHIC

\section{ELEVATION:}

1375(1300-1424)M

SOIL DRAINAGE:

WELL TO MODERATELY WELL

SLOPE:

$$
7(2-10) \%
$$

\section{ASPECT:}

SOUTHERLY

\section{Forage Production KG/HA}

GRASS 2775(2552-3132)

FORBS 507(306-608)

TOTAL 3282(2946-3160)

SugGESTED GRAZING CAPACITY 0.3 HA/AUM 


\section{SASMC4. Fringed sage/Kentucky bluegrass-Sedge \\ (Artemisia frigida/Poa pratensis-Carex spp.)}

$\mathbf{n}=1 \quad$ This community type was described on a south facing slope and ridge top in the South Sheep allotment. It appears to represent long-term heavy grazing pressure on a Parry oatgrass-Rough fescue-Sedge dominated community type. The increased grazing pressure on these south facing slopes favours the growth of fringed sage, sedge, Kentucky bluegrass and dandelion. It is unusual having such a high cover of Kentucky bluegrass on these slopes. Kentucky bluegrass usually prefers moister lower slope positions. Perhaps the higher precipitation received in the Subalpine subregion compared to the Montane makes the south facing slopes more favorable to Kentucky bluegrass invasion.

There is still a strong component of native species in this community type and recovery is likely if the grazing pressure is reduced.

\section{PlantCompositioncanopyCover(\%)}

\section{SHRUBS}

MEan Range CONST.

PASTURE SAGE

(Artemisia frigida)

SHRUBBY CINQUEFOIL

(Potentilla fruticosa)

$\begin{array}{lll}16 & - & 100 \\ 4 & - & 100\end{array}$

\section{FORBS}

GOLDEN BEAN

(Thermopsis rhombifolia) 5

EARLY YELLOW LOCOWEED

(Oxytropis sericea) 2

COMMON DANDELION

(Taraxacum officinale) 2

NATIVE VETCH

(Vicia americana)

COMMON GOATS BEARD

(Tragopogon dubius)

GRASSES

KENTUCKY BLUEGRASS

(Poa pratensis)

PARRY OATGRASS

(Danthonia parryi)

ROUGH FESCUE

(Festuca scabrella.)

COLUMBIA NEEDLE GRASS

(Stipa columbiana)

JUNEGRASS

(Koeleria macrantha)

SEDGE SPP.

(Carex spp.)

3

3

100

100

100

ENVIRONMENTAL VARIABLES
100

100
MOISTURE REGIME:

XERIC

NUTRIENT REGIME:

SUBMESOTROPHIC

ELEVATION:

$1450 \mathrm{M}$

SOIL DRAINAGE:

RAPIDLY

SLOPE:

$33 \%$

ASPECT:

SOUTHERLY

\section{Forage Production KG/HA}

GRASS 704

FORB $\quad 490$

SHRUB 236

TOTAL $\quad 1430$

\section{SUGGESTED GRAZING CAPACITY}

$0.6 \mathrm{HA} / \mathrm{UUM}$

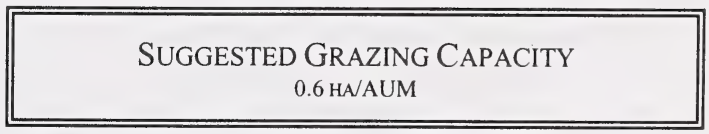




\section{SASMC5. Rough fescue-Kentucky bluegrass \\ (Festuca scabrella-Poa pratensis)}

$\mathbf{n}=1 \quad$ This community type was described in the South Sheep allotment west of Turner valley and represents a rough fescue grassland that has been heavily grazed to the point of Kentucky bluegrass invasion and is now recovering. Long-term heavy grazing pressure leads to a decline in rough fescue and an increase in Parry oatgrass and sedge species. Continued grazing pressure reduces the competitive advantage of rough fescue and the other native grass species and allows Kentucky bluegrass to establish on site. Protection or a reduction in stocking level at the point where Kentucky bluegrass becomes a significant of the community allows rough fescue to recover, but it seems Kentucky bluegrass also remains as co-dominant.

\section{Plant COMPOSITION CANOPY COVER(\%)} MEAN RANGe CONST.

\section{SHRUBS}

LIMBER PINE

(Pinus flexilis)

SHRUBBY CINQUEFOIL

(Potentilla fruticosa)

1

10

100

\section{FORBS}

GOLDEN BEAN

(Thermopsis rhombifolia) 1

SILKY PERENNIAL LUPINE

(Lupinus sericea)

COMMON DANDELION

(Taraxacum officinale)

NATIVE VETCH

(Vicia americana)

MOUNTAIN GOLDENROD

(Solidago spathulata)

\section{GRASSES}

KENTUCKY BLUEGRASS

(Poa pratensis)

CALIFORNIA OATGRASS

(Danthonia californica)

ROUGH FESCUE

(Festuca scabrella.

HAIRY WILDRYE

(Elymus innovatus)
4

1

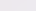

1

2

15
100

100

\section{ENVIRONMENTAL VARIABLES}

MOISTURE REGIME:

MESIC

NUTRIENT REGIME:

PERMESOTROPHIC

ELEVATION:

$1500 \mathrm{M}$

SOIL DRAINAGE:

WELL

SLOPE:

$0 \%$

Forage Production Kg/HA

Total $2000 *$ Estimate

100

SUGGESTED GRAZING CAPACITY

$0.5 \mathrm{HA} / \mathrm{AUM}$ 


\section{SASMC6. Kentucky bluegrass-Rough fescue \\ (Poa pratensis-Festuca scabrella)}

$\mathrm{n}=13$ Long-term heavy grazing pressure leads to a decline in rough fescue and an increase in Parry oatgrass and sedge species. Continued grazing pressure reduces the competitive advantage of rough fescue and the other native grass species and allows Kentucky bluegrass to establish on site. Continued heavy grazing pressure eventually leads to a decline in all native species and the plant community will resemble a Timothy-Kentucky bluegrass/dandelion type.

The forage productivity of this community type $(2300 \mathrm{~kg} / \mathrm{ha})$ is equivalent to or better than a lightly grazed Rough fescue dominated community $(1900 \mathrm{~kg} / \mathrm{ha})$. However, rough fescue is a more desirable forage species because it maintains it nutrient content into the dormant season. In contrast, Kentucky bluegrass loses its palatability and nutrient content if is allowed to flower and set seed.

\section{Plant Composition Canopy Cover(\%)} MEan Range Const.

\section{SHRUBS}

ASPEN

$\begin{array}{cccc}\begin{array}{c}\text { (Populus tremuloides) } \\ \text { SHRUBBy CINQUEFOIL }\end{array} & 1 & 0-5 & 23 \\ \text { (Potentilla fruticosa) } & 2 & 1-8 & 92\end{array}$

\section{FORBS}

THREE FLOWERED AVENS

(Geum triflorum) $\quad 3 \quad 0-16 \quad 69$

WILD STRAWBERRY

(Fragaria virginiana) $2 \quad 0-8 \quad 85$

GRACEFUL CINQUEFOIL

(Potentilla gracilis) $\quad 3 \quad 0-13 \quad 69$

LATE YELLOW LOCOWEED

(Oxytropis monticola) 1

YELLOW FALSE DANDELION

$\begin{array}{llll}\text { (Agoseris glauca) } & 1 & 0-10 \quad 62\end{array}$

GraSSES

KENTUCKY BLUEGRASS

(Poa pratensis P.compressa)7 $\quad 2-21 \quad 100$

TIMOTHY

(Phleum pratense) $\quad 4 \quad 0-21 \quad 77$

ROUGH FESCUE

$\begin{array}{llll}\text { (Festuca scabrella.) } & 2 & 0-5 & 69\end{array}$

IDAHO FESCUE

(Festuca idahoensis) $\quad 2 \quad 0-12 \quad 69$

\section{ENVIRONMENTAL VARIABLES}

MOISTURE REGIME:

SUBXERIC TO SUBHYGRIC

NUTRIENT REGIME:

SUBMESOTROPHIC TO PERMESOTROPHIC

(POOR TO RICH)

ELEVATION:

$$
1630(1502-1798) \mathrm{M}
$$

SOIL DRAINAGE:

VERY RAPIDLY TO MODERATELY WELL

SLOPE: $\quad 20(2-45) \%$

ASPECT: VARIABLE

\section{Forage Production Kg/HA}

GRASS 1382(85-3584)

FORB $\quad 887(126-2312)$

SHRUB $14(0-45)$

TOTAL 2258(421-4733)
SUGGESTED GRAZING CAPACITY $0.4 \mathrm{ha} / \mathrm{AUM}$ 


\section{SASMC7. Timothy-Kentucky bluegrass/Dandelion \\ (Phleum pratense-Agropyron trachycaulum/Epilobium angustifolium)}

$\mathbf{n}=\mathbf{8}$ This community type was described in moist lower slope positions. Heavy grazing pressure has caused the native grass species to decline and allowed Canada bluegrass and timothy to invade onto the site. The presence of fireweed indicates that the site will likely succeed to an aspen dominated community type.

This community type is highly productive and it is easily accessible to domestic livestock. It should be rated as primary range.

\section{Plant COMPOSITION Canopy Cover(\%)}

SHRUBS

\section{MEAN RANGe CONST.}

PRICKLY ROSE

(Rosa acicularis)

$2 \quad 0-10 \quad 50$

SHRUBBY CINQUEFOIL

(Potentilla fruticosa)

$1 \quad 0-2 \quad 38$

FORBS

GRACEFUL CINQUEFOIL

(Potentilla gracilis) 6

FIREWEED

(Epilobium angustifolium)2

COMMON DANDELION

(Taraxacum officinale) $\quad 11 \quad 1-26 \quad 100$

NATIVE VETCH

(Vicia americana) 3

STICKY PURPLE GERANIUM

(Geranium viscosissimum)5

Grasses

TIMOTHY

(Phleum pratense)

$50 \quad 19-64 \quad 100$

SLENDER WHEATGRASS

(Agropyron trachycaulum)2

ROUGH FESCUE

CALIFORNIA OATGRASS

$\begin{array}{llll}\text { (Danthonia californica) } & 2 & 0-15 & 14\end{array}$

KENTUCKY BLUEGRASS

(Poa pratensis)

$4 \quad 0-11 \quad 86$

SEDGE

(Carex spp.)
MOISTURE REGIME:

MESIC

NUTRIENT REGIME:

MESOTROPHIC

ELEVATION:

1511(1524-1655)M

SOIL DRAINAGE:

WELL

SLOPE:

$5(1-5) \%$

ASPECT:

VARIABLE

Forage Production KG/HA

GRASS 4030(1368-7740)

FORB 863(550-1060)

SHRUB 33(0-144)

TOTAL 4926(2482-8494)

\section{SUGGESTED GRAZING CAPACITY \\ 0.2 HA/AUM}

\section{ENVIRONMENTAL VARIABLES}




\section{SASMC8. Marsh reedgrass-Timothy/Cow parnsip \\ (Calamagrostis canadensis-Phleum pratense/Heracleum lanatum)}

$\mathbf{n}=\mathbf{1} \quad$ This community type represents seepage areas in the foothills west of Turner valley. Often these areas are invaded by willow to form the Willow/Marsh reedgrass dominated community type. This community type is very similar to the Marsh reedgrass/Cow parnsip community previously described, but this community has a high cover of timothy. Timothy, Kentucky bluegrass and dandelion will often invade these sites when exposed to heavy grazing pressure. This community type is highly productive and should be rated as primary range.

\section{Plant Composition Canopy Cover(\%)} MEAN RANGE CONST.

\section{SHRUBS}

RASPBERRY

(Rubus idaeus)

100

\section{FORBS}

COW PARSNIP

FIREWEED

(Epilobium angustifolium) 3

COMMON DANDELION

(Taraxacum officinale) 3

CANADA VIOLET

(Viola canadensis)

WHITE GERANIUM

(Geranium richardsonii) 10

WESTERN MEADOW RUE

(Thalictrum occidentalis) 15

100

100

100

100

100

100

GRASSES

TIMOTHY

\section{(Phleum pratense)}

29

SLENDER WHEATGRASS

(Agropyron trachycaulum) 3

MOUNTAIN BROME

$\begin{array}{llll}\text { (Bromus carinatus.) } & 2 & - & 100\end{array}$

MARSH REEDGRASS

(Calamagrostis canadensis)37 - 100

\section{ENVIRONMENTAL VARIABLES}

\section{MOISTURE REGIME:}

SUBHYGRIC

NUTRIENT REGIME:

PERMESOTROPHIC

ELEVATION:

$1570 \mathrm{M}$

SOIL DRAINAGE:

MOD. WELL

SLOPE:

$10 \%$

ASPECT:

VARIABLE

\section{Forage Production Kg/HA}

GRASS

1369

FORB

1245

TOTAL

2613

SugGESTED GRAZING CAPACITY 0.4 HA/AUM 


\section{SASMC9. Idaho fescue-Rough fescue/Bearberry \\ (Festuca idahoensis-Festuca scabrella/Arctostaphylos uva-ursi)}

$\mathbf{n}=\mathbf{2} \quad$ This community type represents a Rough fescue/Bearberry plant community that has been heavily to moderately grazed for a number of years. Increased grazing pressure causes rough fescue to decline and allows Idaho fescue, timothy and sedge species to increase. If grazing pressure is reduced on this site it will likely succeed back to a rough fescue dominated community.

\section{Plant Composition Canopy Cover(\%) MEAN RANGE CONST.}

\section{SHRUBS}

SHRUBBY CINQUEFOIL

$\begin{array}{llll}\text { (Potentilla fruticosa) } & 1 & 1-2 & 100\end{array}$

COMMON JUNIPER

(Juniperus communis)

$7 \quad 0-15 \quad 50$

\section{FORBS}

BEARBERRY

(Arctostaphylos uva-ursi) $22 \quad 13-30 \quad 100$

OLD MANS WHISKERS

(Geum triflorum)

$\begin{array}{lll}16 & 4-27 \quad 100\end{array}$

STRAWBERRY

(Fragaria virginiana) $\quad 11 \quad 4-16 \quad 100$

YARROW

(Achillea millefolium)

NORTHERN BEDSTRAW

(Galium boreale)

AMERICAN VETCH

(Vicia americana)

6

$\begin{array}{lll}7 & 6-8 & 100\end{array}$

$\begin{array}{lll}6 & 5-7 & 100\end{array}$

$6 \quad 2-9 \quad 100$

\section{GRASSES}

IDAHO FESCUE

(Festuca idahoensis) $\quad 26 \quad 20-31 \quad 100$

ROUGH FESCUE

(Festuca scabrella) - 9

NORTHERN WHEATGRASS

(Agropyron dasystachyum) 5

JUNEGRASS

(Koeleria macrantha) 4

\section{ENVIRONMENTAL VARIABLES}

MOISTURF REGIME:

SUBMESIC

NUTRIENT REGIME:

MESOTROPHIC

ELEVATION:

$1500-1510(1505 \mathrm{M})$

SOIL DRAINAGE:

WELL

SLOPE:

$2(1-3 \%)$

ASPECT:

VARIABLE

\section{Forage Production KG/Ha}

GRASS 1408(1012-1804)

FORB 862(434-1290)

SHRUB 43(0-86)

TOTAL 2313(2302-2324)

\section{SUGGESTED GRAZING CAPACITY}

$0.4 \mathrm{HA} / \mathrm{AUM}$ 


\section{SUBALPINE SUBREGION}

\section{SOUTHERN ECODISTRICTS}

\section{FORESTED COMMUNITY TYPES}

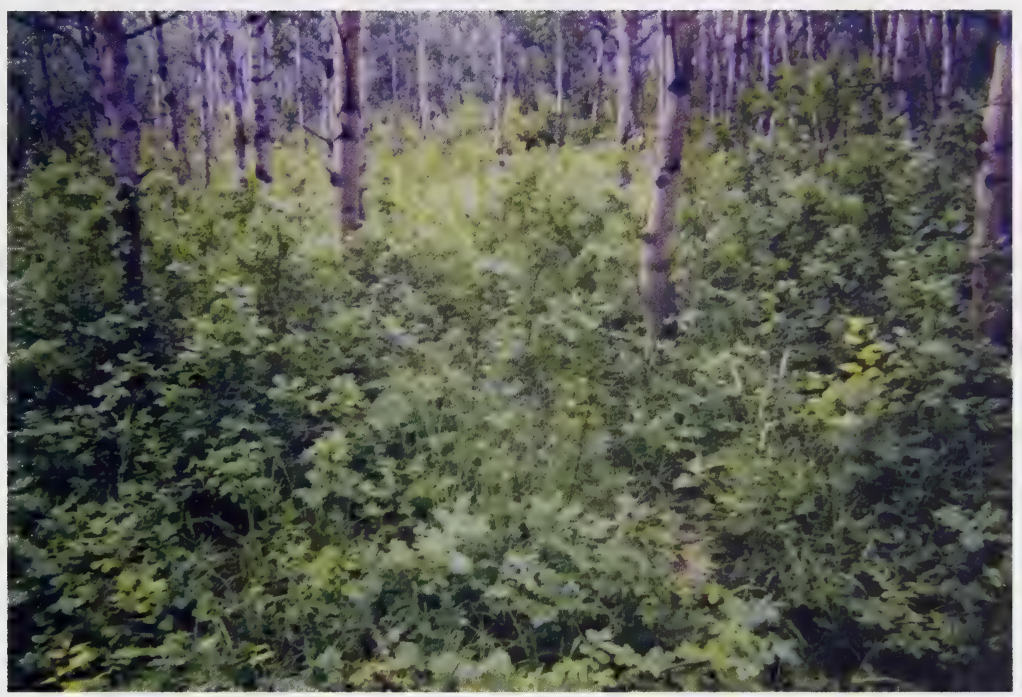

Figure 7. Deciduous communities are not common in the Subalpine, but where they do occur they can be very productive for domestic livestock. This picture represents an Aspen/Rose/Pinegrass dominated community, which can be common on warmer sites in the Subalpine subregion of southern Alberta. 


\section{SUBALPINE SUBREGION}

\section{FOREST ECOLOGY}

The forested plant communities in the subalpine can be split into three zones. These include the Pine, Spruce-Fir and Upper Subalpine zones (Strong and Leggat 1992). The Pine zone is the lowest elevation zone and is dominated by lodgepole pine and shows little evidence of succession to Engelmann spruce. It is within this zone that aspen and balsam poplar dominated plant communities can occur on warmer sites. The Spruce-Fir zone is located altitudinally above the Pine zone (Strong and Leggat 1992). This zone displays evidence of lodgepole pine succession to Engelmann spruce and subalpine fir. The Upper subalpine zone is characterized by open canopied vegetation that occurs between the Spruce-Fir zone and timberline. This zone is dominated by dwarfed Engelmann spruce, alpine fir, whitebark pine and alpine larch. Plant growth in this upper zone is limited by low temperatures, wind, low moisture and a short growing season (Strong and Leggat 1992). There are only a handful of forested community types described in this guide. Archibald et al. (1996), provide a good descriptions of the major forested community types in the Subalpine subregion that are not represented in this guide. Generally, these forested plant communities only provide limited forage for domestic livestock, but where deciduous communities are extensive they can be heavily utilized by livestock and should be considered secondary range. 

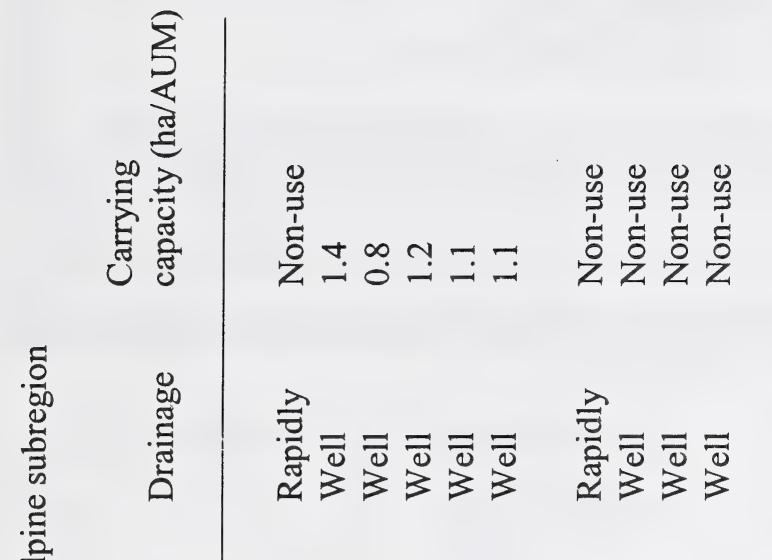

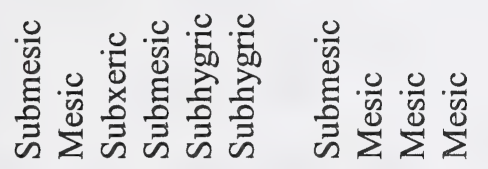

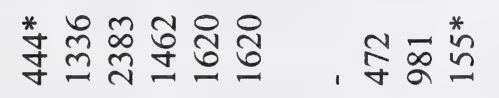

, Эส๙

, ㄱํำ

,

岌 0 1

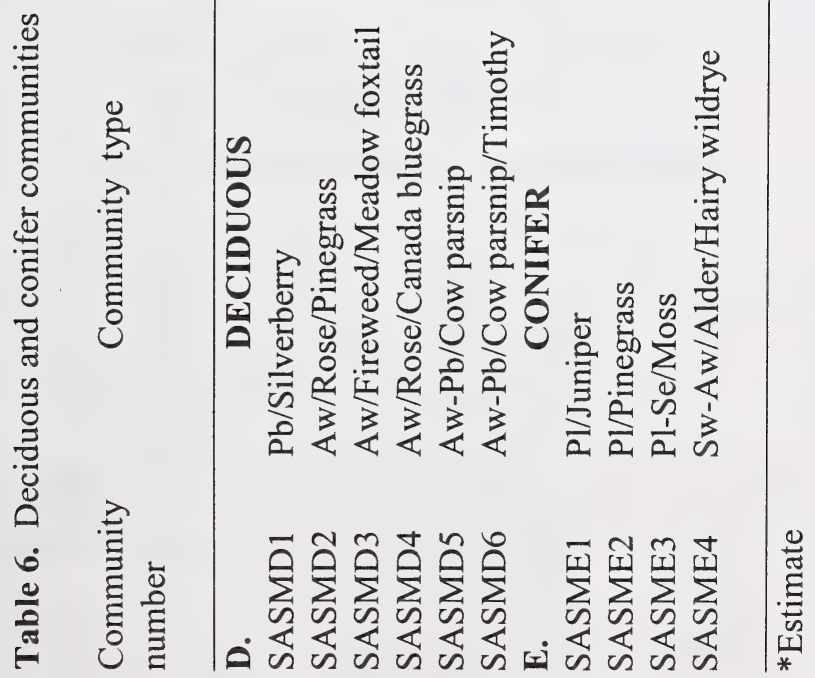




\section{SASMD1. Pb/Silverberry \\ (Populus balsamifera/Elaeagnus commutata)}

$\mathbf{n}=\mathbf{1}$ This community type was described along the banks of Pekisko creek in the Pekisko Creek allotment. It is characteristic of dry gravelly, river flats, which are periodically flooded in the spring. This community type is very similar to the yellow mountain avens community which have been described in both the Montane and Subalpine subregions.

Generally, there is little forage for domestic livestock in this community type and it should be rated as nonuse.

\section{PLANT COMPOSITION $\cdots$ py COVER(\%)}

MeAN RANGe CONST.

TREES

BALSAM POPLAR

(Populus balsamifera) $15 \quad-\quad 100$

\section{SHRUBS}

PRICKLY ROSE

(Rosa acicularis)

SILVERBERRY

(Elaeagnus commutata) $5 \quad-\quad 100$

SHRUBBY CINQUEFOIL

$\begin{array}{llll}\text { (Potentilla fruticosa) } & 1 & - & 100\end{array}$

FALSE MOUNTAIN WILLOW

(Salix pseudomonticola) 2

FORBS

ALPINE HEDYSARUM

(Hedysarum alpinum)

COMMON HORSETAIL

(Equisetum arvense)

CUT-LEAVED ANEMONE

(Anemone multifida)

GRACEFUL CINQUEFOIL

(Potentilla gracilis)

Grasses

BLUE BUNCH WHEATGRASS

(Agropyron spicatum)

JUNE GRASS

(Koeleria macrantha)

CANADA BLUEGRASS

(Poa compressa)

HAIRY WILD RYE

(Elymus innovatus)

\section{ENYIRONMENTAL VARIABLES}

MOISTURE REGIME :

SUBMESIC

NUTRIENT REGIME :

MESOTROPHIC

ELEVATION:

$1828 \mathrm{M}$

SoIL DRAINAGE :

RAPIDLY

SLOPE:

$18 \%$

ASPECT:

SOUTHEAST

Forage Production Kg/HA

TOTAL 444 *ESTIMATE

100

100

SUGGESTED GRAZING CAPACITY

NON-USE 


\section{SASMD2. Aw/Rose/Pinegrass \\ (Populus tremuloides/Rosa/Calamagrostis rubescens)}

$\mathbf{n = 2 0}$ This community type is similar to the Aw/Rose/Pinegrass community which is described on mesic sites with medium nutrient regimes in the Montane subregion. It may represent the transition from the Montane to the Subalpine. These sites were described at lower elevations in the Subalpine and generally had southerly aspects, making the conditions more suitable for growing aspen. The forage productivity on this community type is moderate and it should be rated as secondary range.

\section{Plant Composition Canopy Cover(\%) MEAN RANGe Const.}

TREES

ASPEN

(Populus tremuloides) $\quad 34 \quad 20-50 \quad 100$

WHITE SPRUCE

(Picea glauca)

BALSAM POPULAR

(Populus balsamifera)

$2 \quad 0-5 \quad 25$

$2 \quad 0-15 \quad 20$

\section{SHRUBS}

PRICKLY ROSE

(Rosa acicularis) $\quad 6 \quad 1-28 \quad 90$

SNOWBERRY

(Symphoricarpose albus) $1 \quad 0-5 \quad 50$

WHITE MEADOWSWEET

(Spiraea betulifolia) $4 \quad 0-31 \quad 50$

WILD RED RASPBERRY

(Rubus idaeus)

$1 \quad 0-8 \quad 30$

FORBS

WILD VETCH

(Vicia americana) 5

CREAM COLORED VETCHLING

(Lathyrus ochroleucus) 7

WILD STRAWBERRY

(Fragaria virginiana) $\quad 5 \quad 0-11 \quad 95$

SHOWY ASTER

(Aster conspicuus)

COMMON FIREWEED

(Epilobium angustifolium)5

COMMON DANDYLION

(Taraxacum officinale) 1

WESTERN CANADIAN VIOLET

(Viola canadensis)

3

GRASSES

PINEGRASS

(Calamagrostis rubescens) 14

$0-24 \quad 80$

$0-24 \quad 80$

$0-5 \quad 70$

$0-10 \quad 30$
HAIRY WILDRYE

(Elymus innovatus) $\quad 5 \quad 0-9 \quad 85$

\section{ENVIRONMENTAL VARIABLES}

MOISTURE REGIME :

SUBMESIC TO SUBHYGRIC

NUTRIENT REGIME :

MESOTROPHIC

ELEVATION:

1508(1400-1768)M

SOIL DRAINAGE :

WELL TO IMPERFECTLY

SLOPE:

$13(6-20) \%$

ASPECT:

VARIABLE

Forage Production Kg/HA

GRASS 603(160-1512)

FORB 621(44-1151)

SHRUB 112(0-726)

TOTAL 1336(416-2034)

SugGESTED GRAZING CAPACITY

1.4HA/AUM 


\section{SASMD3. Aw/Fireweed/Meadow foxtail \\ (Populus tremuloides/Epilobium angustifolium/Alopecurus pratensis)}

$\mathbf{n}=\mathbf{1}$ This community type was described in the South Sheep allotment on an old range improvement area. Many aspen stands in the South Sheep were cleared and seeded to mixture of brome, meadow foxtail, creeping red fescue and clover. This site represents invasion of aspen back into these range improvement areas. Meadow foxtail is generally unpalatable to livestock and has persisted on these sites.

This community is very productive and efforts should be made to control the aspen invasion.

\section{Plant Composition Canopy Cover(\%)} Mean Range CONST.

\section{TREeS}

ASPEN

$\begin{array}{llll}\text { (Populus tremuloides) } & 36 & - & 100\end{array}$

SHRUBS

PRICKLY ROSE

(Rosa acicularis)

PIN CHERRY

$\begin{array}{llll}\text { (Prunus pensylvanica) } & 1 & - & 100\end{array}$

FORBS

COMMON FIREWEED

(Epilobium angustifolium) 12

STICKY PURPLE GERANIUM

(Geranium viscosissimum) 8

LINDLEY'S ASTER

(Aster ciliolatus)

COMMON VETCH

(Vicia americana)

CREAM COLORED VETCHLINO

(Lathyrus ochroleucus) 2

\section{GRASSES}

MEADOW FOXTAIL

(Alopecurus pratensis)

ORCHARDGRASS

(Dactylis glomerata) 17

KENTUCKY BLUEGRASS

(Poa pratensis)

3

TIMOTHY

(Phleum pratense)
100

100

100

100

100

100
ENVIRONMENTAL VARIABLES

MOISTURE REGIME :

MESIC TO SUBHYGRIC

NUTRIENT REGIME :

MESOTROPHIC

ELEVATION:

$1400 \mathrm{M}$

SOIL DRAINAGE :

WELL

SLOPE:

$10 \%$

ASPECT:

SOUTHWEST

Forage Production Kg/HA

GRASS 1612

FORB 679

SHRUB 92

TOTAL 2383

SUGGESTED GRAZING CAPACITY $0.8 \mathrm{HA} / \mathrm{AUM}$ 


\section{SASMD4. Aw/Rose/Canada bluegrass \\ (Populus tremuloides/Rosa spp./Poa compressa)}

$\mathbf{n}=1 \quad$ This community type represents a Aw/Rose/Pinegrass community that has been heavily grazed and invaded by Canada bluegrass. Canada bluegrass is an introduced grass that increases with increased grazing pressure. As grazing pressure increases in these aspen dominated community types there is a shift away from native species (rose, pinegrass, asters, fireweed) to a community that is dominated by bluegrass, timothy, dandelion and clover species. The invasion of non-native invaders onto the site makes this community very productive for domestic livestock, but the presence of overgrazed communities indicates some type of distribution problem and the management of the disposition should be discussed.

\section{Plant COMPOSITION CANopy Cover(\%)} MEan Range Const.

TREES

ASPEN

(Populus tremuloides)

WHITE SPRUCE

(Picea glauca)

35

100

SHRUBS

PRICKLY ROSE

(Rosa acicularis)

WILD RED RASPBERRY

(Rubus idaeus)

NORTHERN GOOSEBERRY

(Ribes oxyacanthoides)

\section{FORBS}

\section{LINDLEY'S ASTER}

(Aster ciliolatus)

WILD STRAWBERRY

(Fragaria virginiana)

COMMON DANDYLION

(Taraxacum officinal)

COMMON FIREWEED

(Epilobium angustifolium) 4

CREAM COLORED VETCHLING

(Lathyrus ochroleucus) 4

\section{GRASSES}

CANADA BLUEGRASS

(Poa compressa)

PINE REEDGRASS

(Calamagrostis rubescens) 9

HAIRY WILDRYE

(Elymus innovatus) 9

AWNLESS BROME

(Bromus inermis)

\section{ENVIRONMENTAL VARIABLES}

MOISTURE REGIME :

SUBMESIC

NUTRIENT REGIME :

MESOTROPHIC

ELEVATION:

$1420 \mathrm{M}$

SOIL DRAINAGE :

WELL

SLOPE:

$10 \%$

ASPECT:

\section{SOUTHWEST}

\section{Forage Production KG/HA}

$\begin{array}{ll}\text { GrASS } & 1036 \\ \text { FORB } & 348 \\ \text { SHRUB } & 78 \\ \text { TOTAL } & 1462\end{array}$

Suggested GRAZING CAPACITY $1.2 \mathrm{HA} / \mathrm{AUM}$ 


\section{SASMD5. Aw-Pb/Cow parsnip \\ (Populus tremuloides-Populus balsamifera/Heracleum lanatum)}

$\mathbf{n}=\mathbf{3}$ Nutrient seepage occurs at some point in the growing season favouring the growth of cow parsnip. This community type is very similar to the Aw/Thimbleberry community described in the Montane subregion. Forage productivity on these sites is generally quite hig because of the favourable moisture and nutrient conditions. Cow parsnip is palatable to livestock and maybe extensively utilized. This community type should be rated as secondary range.

Plant CoMposition Canopy Cover(\%) MEAN RANGe CONST.

TREES

ASPEN

(Populus tremuloides)

BALSAM POPLAR

(Populus balsamifera)

$17 \quad 0-30$

$18 \quad 10-30 \quad 100$

SHRUBS

WILD RED RASPBERRY

(Rubus idaeus)

(Ribes oxyacanthoides)

$1 \quad 0-1$

67

$2 \quad 0-5 \quad 33$

\section{FORBS}

CREAM COLORED VETCHLING

(Lathyrus ochroleucus) 5

COW PARSNIP

(Heracleum lanatum) 31

LINDLEY'S ASTER

(Aster ciliolatus)

WESTERNCANADA VIOLET

(Viola canadensis)

$22 \quad 20-24 \quad 100$

TALL LUNGWORT

(Mertensia paniculata) 5

TALL LARKSPUR

(Delphinium glaucum)

COMMON FIREWEED

(Epilobium angustifolium) 4

COMMON DANDYLION

(Taraxacum officinale)

6

$1-15 \quad 100$

$1-12 \quad 100$

$1-11 \quad 100$

3-5 $\quad 100$

$1-2 \quad 100$

GraSSES

MARSH REEDGRASS

$\begin{array}{lll}\text { (Calamagrostis canadensis) } 4 & 0-7 & 67\end{array}$

HAIRY WILDRYE

(Elymus innovatus)

AWNLESS BROME

(Bromus inermis)

2

$1-2$

100

$2 \quad 1-5 \quad 100$
TiмOTHY

$\begin{array}{llll}\begin{array}{l}\text { (Phleum: pratense) } \\ \text { SEDGE }\end{array} & 2 & 1-3 & 100 \\ \text { (Carex spp.) } & 1 & 1-2 & 100\end{array}$

\section{ENVIRONMENTAL VARIABLES}

MOISTURE REGIME :

SUBHYGRIC

NUTRIENT REGIME :

MESOTROPHIC-PERMESOTROPHIC

ELEVATION:

$1400 \mathrm{M}$

SOIL DRAINAGE :

WELL

SLOPE:

$8 \%$

ASPECT:

SOUTHWEST

Forage Production Kg/HA

GRASS 328

FORB 1200

SHRUB 92

TOTAL 1620

SUGGESTED GRAZING CAPACITY

$1.1 \mathrm{HA} / \mathrm{AUM}$ 


\section{SASMD6. Aw-Pb/Cow parsnip/Timothy}

(Populus tremuloides-Populus balsamifera/Heracleum lanatum/Phleum pratense)

$\mathbf{n = 1} \quad$ Nutrient seepage occurs at some point in the growing season favouring the growth of cow parsnip. This community type is very similar to the previously described $\mathrm{Aw}-\mathrm{Pb} / \mathrm{Cow}$ parsnip community, but this community has a high cover of timothy. Increased grazing pressure will often allow timothy, Kentucky bluegrass and dandelion to invade onto these sites. Forage productivity on these sites is generally quite high because of the favourable moisture and nutrient conditions. Cow parsnip is palatable to livestock and maybe extensively utilized.

This community type should be rated as secondary range.

Plant Composition Canopy Cover(\%) mean Range Const.

TREeS

ASPEN

(Populus tremuloides)

BALSAM POPLAR

(Populus balsamifera)

26

100

$16 \quad-\quad 100$

\section{SHRUBS}

WILD RED RASPBERRY

(Rubus idaeus)

4

100

FORBS

CREAM COLORED VETCHLING

(Lathyrus ochroleucus) 2

COW PARSNIP

(Heracleum lanatum) 2

LINDLEY'S ASTER

(Aster ciliolatus)

WESTERNCANADA VIOLET

(Viola canadensis) 2

TALL LUNGWORT

(Mertensia paniculata) 1

WESTERN MEADOW RUE

(Thalictrum occidentalis) 4

COMMON FIREWEED

(Epilobium angustifolium) 1

COMMON DANDELION

(Taraxacum officinale) 6

GRASSES

MARSH REEDGRASS

(Calamagrostis rubescens) $4 \quad$ - $\quad 100$

SMOOTH WILDRYE

(Elymus glaucus)

AWNLESS BROME

(Bromus inermis)

TIMOTHY

(Phleum pratense)
SEDGE

$\begin{array}{lll}\text { (Carex spp.) } & 3 & -\end{array}$

\section{ENVIRONMENTAL VARIABLES}

MOISTURE REGIME :

SUBHYGERIC

NUTRIENT REGIME :

PERMESOTROPHIC

ELEVATION:

$1510 \mathrm{M}$

SOIL DRAINAGE :

MOD. WELL

SLOPE:

$10 \%$

ASPECT:

VARIABLE

Forage Production KG/HA

GRASS 328

FORB 1200

SHRUB 92

TOTAL 1620

SugGeStED GRAZING CAPACITY

$1.1 \mathrm{HA} / \mathrm{AUM}$ 


\section{SASME1. PI/Juniper \\ (Pinus contorta/Juniperus spp.)}

$\mathbf{n}=1 \quad$ Dry site conditions from south exposures or coarse textured soils are characteristic of this community type (Archibald et al. 1996). The dry site conditions limit the amount of forage this site can produce and the steep slope limits access to livestock. As a result, this community would be considered non-use.

\section{Plant Composition Canopy Cover(\%)} Mean Range Const.

TREES

LODGEPOLE PINE

(Pinus contorta)

$15-100$

\section{SHRUBS}

GROUND JUNIPER

(Juniperus communis) $15 \quad$ - $\quad 100$

CREEPING JUNIPER

(Juniperus horizontalis) $2 \quad$ - 100

CANADA BUFFALOBERRY

(Shepherdia canadensis) $6 \quad-\quad 100$

PRICKLY ROSE

(Rosa acicularis) $\quad 3 \quad$ - 100

CHOKE CHERRY

$\begin{array}{llll}\text { (Prunus virginiana) } & 2 & - & 100\end{array}$

\section{FORBS}

YELLOW HEDYSARUM

(Hedysarum sulphurescens)3 - 100

BEARBERRY

(Arctostaphylos uva-ursi)8 - 100

SPREADING DOGBANE

(Apocynum androsaemifolium)15 - 100

LINDLEY'S ASTER

(Aster ciliolatus)$$
1
$$

GrasseS

HAIRY WILD RYE

(Elymus innovatus)

SEDGE

(Carex spp.)
MOISTURE REGIME :

SUBMESIC

NUTRIENT REGIME :

OLIGOTROPHIC

ELEVATION:

$1659 \mathrm{M}$

SoIL DRAINAGE :

RAPIDLY

SLOPE:

$22 \%$

ASPECT:

SOUTH

Forage Production KG/HA

Total $350 *$ Estimate

SUGGESTED GRAZING CAPACITY

NON-USE

\section{ENVIRONMENTAL VARIABLES}




\section{SASME2. PI/Pinegrass \\ (Pinus contorta/Calamagrostis rubescens)}

$\mathbf{n}=1$ This community type is very similar to the $\mathrm{Pl} / \mathrm{Pinegrass}$ dominated community described in the Montane subregion (Willoughby et al. 2003). Succession will be to white spruce, but the extensive fire history in the area has resulted in a predominance of lodgepole pine (Archibald et al 1996). Pinegrass is generally unpalatable to livestock, but if grazed early in the spring they will utilize it as a forage source. The forage productivity of this community type is quite low. As a result this community type should be rated as non-use.

\section{Plant CoMposition Canopy Cover(\%)} Mean Range CONST.

TREES

LODGEPOLE PINE

(Pinus contorta)

70

100

SHRUBS

PRICKLY ROSE

(Rosa acicularis)

3

WHITE MEADOWSWEET

(Spiraea betulifolia)

DWARF BILBERRY

(Vaccinium caespitosum) 7

GROUND JUNIPER

(Juniperus communis)

FORBS

TWINFLOWER

(Linneae borealis)

SHOWY ASTER

(Aster conspicuus)

CREAM COLORED VETCHLING

(Lathyrus ochroleucus) 2

WILD STRAWBERRY

(Fragaria virginiana)

HEART-LEAVED ARNICA

(Arnica cordifolia)

WESTERN LOUSEWORT

(Pedicularis bracteosa)

Grasses

PINEGRASS

(Calamagrostis rubescens) 27

HAIRY WILDRYE

(Elymus innovatus)
ENVIRONMENTAL VARIAG:

MOISTURE REGIME :

MESIC

NUTRIENT REGIME :

MESOTROPHIC

ELEVATION:

$1676 \mathrm{M}$

SOIL DRAINAGE :

WELL

SLOPE:

$10 \%$

ASPECT:

EAST

\section{FORAGE PRODUCTION KG/HA}

GRASS 210

FORB 180

SHRUB 154

TOTAL 472

\section{SugGeSTED GRAZING CAPACITY}

NON-USE 


\section{SASME3. PI-Se/Moss \\ (Pinus contorta-Picea engelmannii/Moss spp.)}

$\mathbf{n}=\mathbf{5} \quad$ This community type represents the modal conditions for the Subalpine subregion at mid to lower elevations. Lodgepole pine, Engelmann spruce and subalpine fir can all occur as the dominant tree species on this ecological site. In general succession is from lodgepole pine to Engelmann spruce and subalpine fir. However, lodgepole pine is the most common tree species because of the frequency of fire.

There is little forage for domestic livestock in this community type. As a result, this community should be rated as non-use.

\section{PLANT COMPOSITION : 'PY COVER(\%) Mean Range Const.}

Trees

ENGELMANN SPRUCE

(Picea engelmannii)

WHITE SPRUCE

(Picea glauca)

LODGEPOLE PINE

(Pinus contorta)

$30 \quad 15-60 \quad 100$

\section{SHRUBS}

PRICKLY ROSE

(Rosa acicularis)

DWARF BILBERRY

(Vaccinium caespitosum)2

WHITE MEADOWSWEET

(Spiraea betulifolia)

GREEN ALDER

(Alnus crispa)

3

$0-10$

40

$2 \quad 0-10 \quad 20$

$30 \quad 15-60 \quad 100$

\section{FORBS}

BUNCHBERRY

(Cornus canadensis)

WILD STRAWBERRY

(Fragaria virginiana)

SHOWY ASTER

(Aster conspicuus)

TWINFLOWER

(Linnaea borealis)

BROAD-LEAVED ARNICA

(Arnica latifolia)

$1 \quad 0-1 \quad 80$

$1-3 \quad 100$

$2 \quad 0-5 \quad 80$

$3 \quad 0-8 \quad 40$

\section{GRASSES}

HAIRY WILDRYE

(Elymus innovatus)

PINEGRASS

(Calamagrostis rubescens) 3

RICHARDSON NEEDLEGRASS

(Stipa richardsonii)
8

$1-14$

100

2

$1-4 \quad 100$

$2 \quad 0-3 \quad 80$

$2 \quad 0-6 \quad 80$
Moss

(Moss spp)

10

$1-38$

100

\section{ENVIRONMENTAL VARIABLES}

MOISTURE REGIME :

XeRIC TO MESIC

NUTRIENT REGIME :

SUBMESOTROPHIC TO MESOTROPHIC

ELEVATION:

1647(1536-1770)M

SOIL DRAINAGE : RAPIDLY TO WELL

SLOPE: $\quad 9(0-22) \%$

ASPECT: VARIABLE

\section{Forage Production KG/HA}

GRASS 187

FORB 707

SHRUB 88

TOTAL 981

\section{SUGGESTED GRAZING CAPACITY}

NON-USE 


\section{SASME4. Sw-Aw/Alder/Hairy wildrye \\ (Picea glauca-Populus tremuloides/Alnus crispa/Elymus innovatus)}

$\mathbf{n}=\mathbf{1} \quad$ This community type represents the succession of spruce onto an aspen dominated community type. As succession occurs from aspen to spruce there is a corresponding drop in forage production. This community type has little forage available for domestic livestock and should be rated as non-use.

\section{Plant COMPOSITION CANopy COVER(\%) Mean Range Const.}

\section{TREES}

WHITE SPRUCE

(Picea glauca)

ASPEN

(Populus tremuloides)

LODGEPOLE PINE

(Pinus contorta)

SHRUBS

PRICKLY ROSE

(Rosa acicularis)

DWARF BILBERRY

(Vaccinium caespitosum)

WHITE MEADOWSWEET

(Spiraea betulifolia) 5

GREEN ALDER

(Alnus crispa)

$31 \quad-\quad 100$

$16 \quad-\quad 100$

3

100

\section{FORBS}

ONE SIDED WINTERGREEN

(Orthilia secunda) 2

SHOWY ASTER

(Aster conspicuus)

TWINFLOWER

(Linnaea borealis)

2

2

3

100

100

100

100

GRASSES

HAIRY WILDRYE

(Elymus innovatus) $\quad 3 \quad-\quad 100$

PINEGRASS

(Calamagrostis rubescens)3 $\quad$ - 100

Moss

(Moss spp)

$10 \quad-\quad 100$

\section{ENVIRONMENTAL VARIABLES}

MOISTURE REGIME :

MESIC

NUTRIENT REGIME : MESOTROPHIC

ELEVATION:

$1557 \mathrm{M}$

SOIL DRAINAGE : WELL

SLOPE: $22 \%$

ASPECT: NORTHERLY

FORAGE PRODUCTION KG/HA

TOTAL 155

\section{SUGGESTED GRAZING CAPACITY NON-USE}




\section{ALPINE SUBREGION}

\section{NATIVE GRASSLANDS AND SHRUBLANDS}

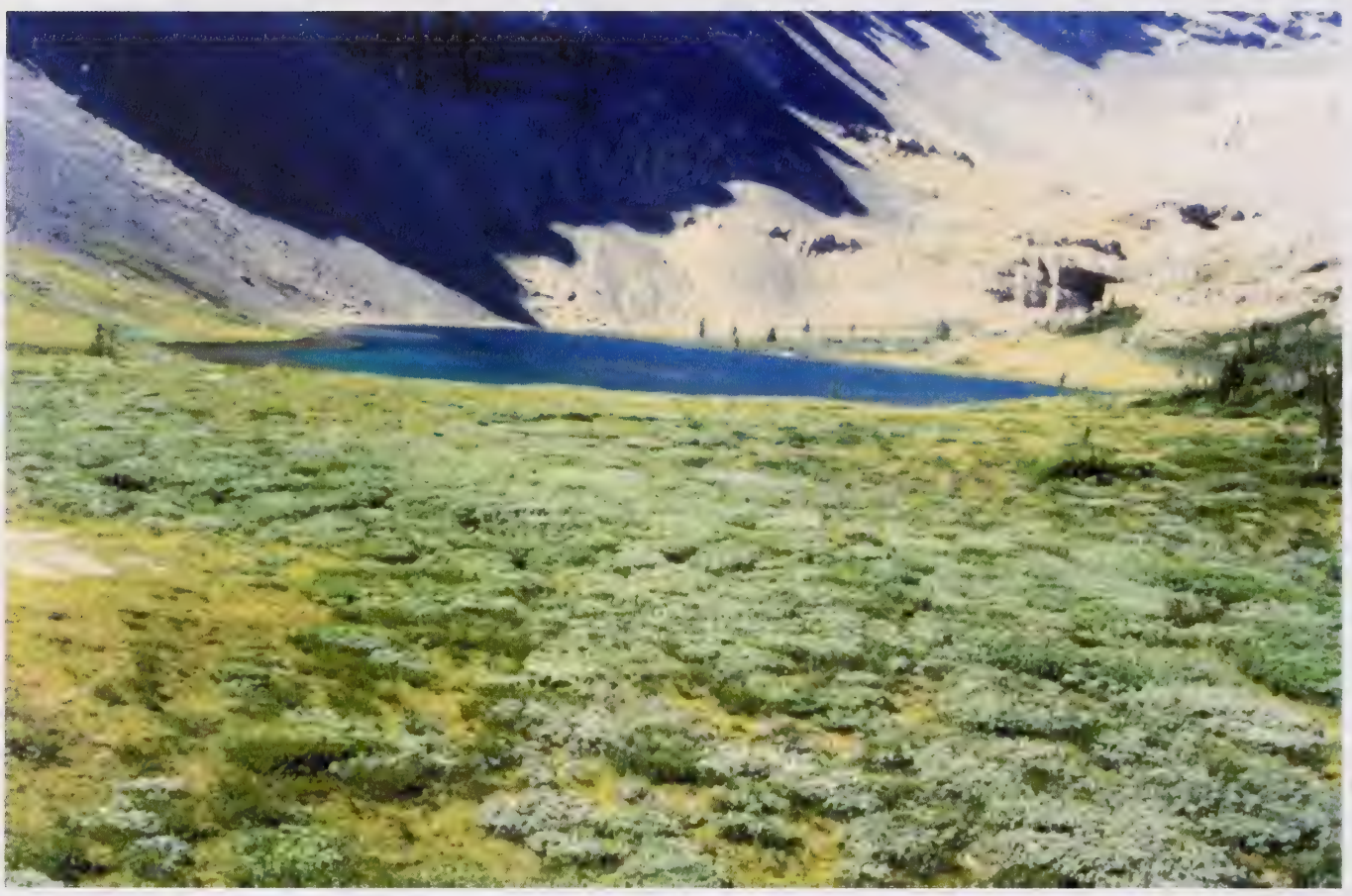

Figure 8. Low growing plant communities of white mountain avens and bog sedge on windswept ridges, with arctic willow, heather and blackening sedge in snow accumulation areas are typical of the Alpine subregion 


\section{Alpine communities}

The alpine environment generally occurs above timberline. Ogilvie (1969), found timberline to be controlled by low temperature, wind dessication, avalanching and snow depth. The alpine plants and communities show adaptations to these extreme environmental conditions. The alpine plant communities tend to be low growing where they are protected from the wind and benefit from the warmer temperatures close to the ground (Ogilvie 1969). Figure 4 outlines the alpine communities in the landscape of the Rocky Mountains. On south facing, wind swept ridges the bog sedge and white dryad communities are found. At slightly lower elevations where snow accumulates the low growing willow communities predominate (arctic willow, snow willow, rock willow). On the north facing slopes where snow accumulates the blackening sedge and heather community types are found. In the valley bottoms below timberline the willow, bog birch, and grassy meadow community types are typical. The sequence of the valley bottom community types in the landscape is described in Figure 2. The plant community types found in the Alpine subregion are listed in Table 7.

Many of these alpine grass and shrublands are very fragile because of exposure and cold climate. The forage productivity is very low compared to the valley bottoms. Consequently, recovery from overgrazing will likely take some time. As a result grazing by domestic livestock in the Alpine subregion should be discouraged. 


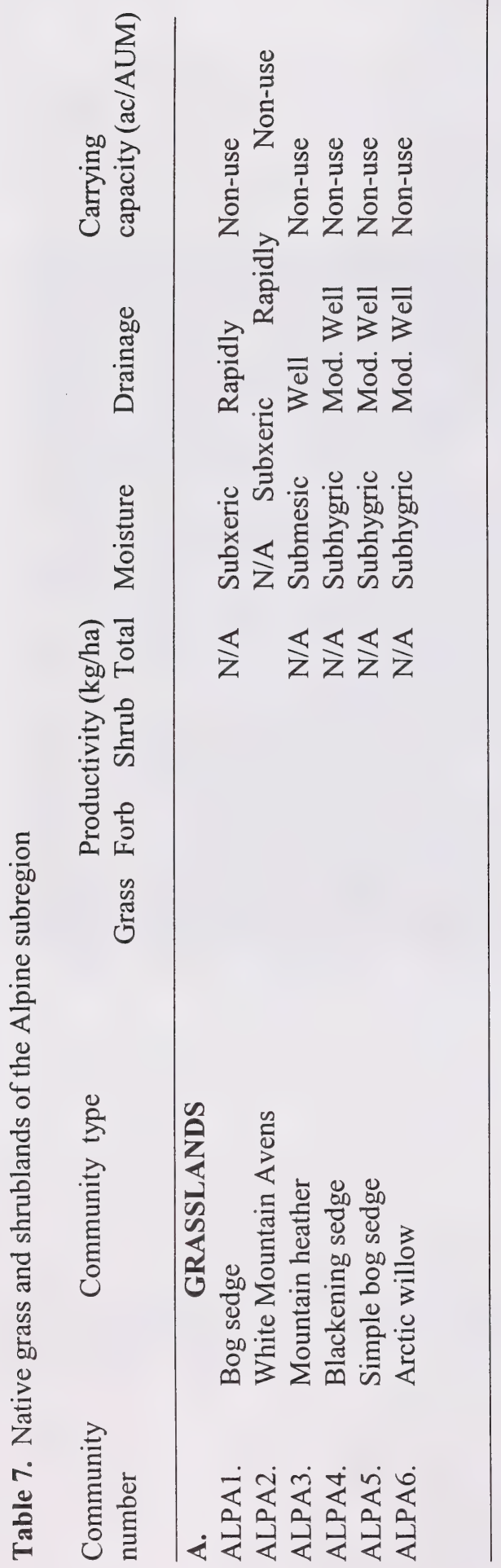

છ0 


\section{ALPA1. Bog sedge \\ (Kobresia myosuroides)}

$\mathbf{n = 5}$ This community type occurs at higher elevations on snow-free, wind-exposed south facing slopes and ridge crests. The soils are shallow, stoney colluvial Regosols (Corns and Achuff 1982). Ogilvie (1969), found that there was rich herb layer, and an abundant lichen and bryophyte layer in this community type.

\section{Plant COMPOSITION CANOPY COVER(\%)} MeAN RANGe CONST.

\section{SHRUBS}

SMOOTH WILLOW

(Salix glauca)

BOG BIRCH

$\begin{array}{llll}\text { (Betula glandulosa) } & 3 & 0-7 & 60\end{array}$

WHITE MOUNTAIN AVENS

(Dryas integrifolia,
D. octopetala)
4
$0-7 \quad 40$

\section{FORBS}

ALPINE HEDYSARUM

(Hedysarum alpinum)

LITTLE CLUBMOSS

(Selaginella densa)

ALPINE BISTORT

$\begin{array}{llll}\text { (Polygonum viviparum) } & 2 & 0-4 & 60\end{array}$

SMOOTH LEAVED CINQUEFOIL

(Potentilla diversifolia) 1

\section{GRASSES}

BOG SEDGE

$\begin{array}{llll}\text { (Kobresia myosuroides) } & 44 & 35-65 & 100\end{array}$

HAIRY WILDRYE

(Elymus innovatus) $\quad 4 \quad 0-10 \quad 80$

ROCKY MTN. FESCUE

(Festuca saximontana) $\quad 1 \quad 0-5 \quad 40$

\section{ENVIRONMENTAL VARIABLES}

MOISTURE REGIME:

SUBXERIC

NUTRIENT REGIME:

OLIGOTROPHIC

ELEVATION:

2042(1900-2260) M

SOIL DRAINAGE:

RAPIDLY

SLOPE:

$$
0-48(19) \%
$$

ASPECT:

SOUTH -SOUTHWEST

Forage Production KG/HA

SUGGESTED GRAZING CAPACITY

NON-USE 


\section{ALPA2. White mountain avens \\ (Dryas octopetala, D. integrifolia)}

$\mathbf{n = 4 3}$ This community type occurs on wind-exposed, snow-free ridges. The soils are shallow, stoney, colluvial Regosols (Corns and Achuff 1982). Ogilvie (1969), found this community to have an abundance of cushion and mat-plants and a large number of lichens.

Plant Composition Canopy Cover(\%) Mean Range CONST.

\section{SHRUBS}

WHITE MOUNTAIN AVENS

(Dryas octopetala,

(Silene acaulis)

$$
\text { D. integrifolia) }
$$

SNOW WILLOW

(Salix reticulata)

WHITE MOUNTAIN HEATHER

(Cassiope tetragona) 3

FORBS

ELEPHANT'S HEAD

(Pedicularis groenlandicum) $\mathrm{T}$

WOOLY EVERLASTING

(Antennaria lanata)

MOSS CAMPION

ALPINE BISTORT

(Polygonum viviparum)

LITTLE CLUBMOSS

(Selaginella densa)

$$
33
$$$$
1-70
$$$$
95
$$

$2 \quad 0-15 \quad 65$

$0-35 \quad 23$

GRASSES

BOG SEDGE

(Kobresia myosuroides) $3 \quad 0-35 \quad 35$

SEDGE SPP.

(Carex spp.)

SPIKED TRISETUM

(Trisetum spicatum)

$2 \quad 0-65 \quad 77$

$0-7 \quad 42$

\section{ENVIRONMENTAL VARIABLES}

MOISTURE REGIME:

SUBXERIC

NUTRIENT REGIME:

SUBMESOTROPHIC

ELEVATION:

2192(1410-2490) M

SOIL DRAINAGE:

RAPIDLY

SLOPE:

$$
0-60(25) \%
$$

ASPECT:

EAST TO WEST

FORAGE PRODUCTION

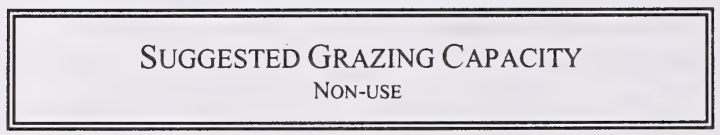




\section{ALPA3. Mountain heather \\ (Cassiope spp.-Phyllodoce spp.)}

$\mathbf{n = 5 8}$ This community type occurs on north facing slopes, with deep snow cover. The soils are Brunisolic, Podzolic and Regosolic and they have seepage and solifluction (Corns and Achuff 1982). Ogilvie (1969), found this community type to have an abundant low shrub layer, a rich byrophyte and lichen layer and a moderately developed herb layer.

This community type includes both the Cassiope tetragona-Dryas octopetala-Salix nivalis and Phyllodoce glanduliflora-Cassiope mertensiana-Antennaria lanata community types described by Corns and Achuff (1982).

\section{Plant Composition Canopy Cover(\%)} MEAN RANGe CONST.

\section{SHRUBS}

WILLOW SPP.

(Salix spp.)

$13 \quad 0-30 \quad 67$

WESTERN MOUNTAIN HEATHER

(Cassiope mertsiana) 27

WHITE MOUNTAIN HEATHER

(Cassiope tetragona) 1

YELLOW HEATHER

(Phyllodoce glanduliflora) 20

RED HEATHER

(Phyllodoce empetriformis)5

\section{FORBS}

LANCED -LEAVED PAINT BRUSH

(Castilleja occidentalis) T

WOOLLY EVERLASTING

(Antennaria lanata)

WESTERN ANEMONE

(Anemone occidentalis)

MOUNTAIN SAGE

(Artemisia norvegica)

GRASSES

REDDISH WOOD RUSH

(Luzula piperi)

SEDGE

(Carex spp.)

$0-75 \quad 86$

$0-15 \quad 16$

$0-60 \quad 20$

$0-25 \quad 40$

$0-1 \quad 16$

$0-15 \quad 85$

$0-30 \quad 26$

$0-15 \quad 53$

$0-5 \quad 33$

$1 \quad 0-12 \quad 66$

T $\quad 0-5 \quad 33$

Forage Production KG/HA

Not AVAILABLE

\section{ENVIRONMENTAL VARIABLES}

MOISTURE REGIME:

SUBMESIC

NUTRIENT REGIME:

MESOTROPHIC

ELEVATION:

2154(194-2410) M

SOIL DRAINAGE:

WELL

SLOPE:

ASPECT:

NORTHERLY
SugGeSTED GRAZING CAPACITY NON-USE 


\section{ALPA4. Blackening sedge \\ (Carex nigricans)}

$\mathbf{n = 7}$ This is a snowpatch community occurring in small channels and depressions where there is very deep snow accumulation (Ogilvie 1969). The soils are predominantly Brunisols, Podzols and Regosols and are moist and free of snow for only a brief period of time (Corns and Achuff 1982). Ogilvie (1969) found these community types to have an abundant herb layer of sedges, grasses and forbs, with only a minor occurrence of dwarf shrubs and mosses.

\section{Plant Composition ranopy Cover(\%)}

MEA、 KANGE CONST.

\section{SHRUBS}

WILLOW

(Salix spp)

T $\quad 0-2 \quad 14$

\section{FORBS}

WOOLLY EVERLASTING

(Antennaria lanata)

MOUNTAIN MARIGOLD

(Caltha leptosepala)

MOUNTAIN BUTTERCUP

(Ranunculus eschscholtzii)1

MARE'S TAIL

(Hippus vulgaris)

Grasses

BLACKENING SEDGE

(Carex nigricans)

$49 \quad 0-90 \quad 100$

TUFTED HAIRGRASS

(Deschampsia caespitosa)4

REDDISH WOOD RUSH

(Luzula piperi)

$\begin{array}{lll}2 & 0-8 & 57\end{array}$

MOUNTAIN HAIRGRASS

(Vahlodea atropurpurea) 4

WHITE RUSH

(Juncus albescens)

2

$\begin{array}{lll}6 & 0-34 & 57\end{array}$

$7 \quad 0-40 \quad 43$

$0-5 \quad 29$

$0-12 \quad 14$

$0-15 \quad 57$

$0-15 \quad 14$

\section{ENVIRONMENTAL VARIABLES}

MOISTURE REGIME:

MESIC TO SUBHYGRIC

NUTRIENT REGIME:

MESOTROPHIC

ELEVATION:

2164(1990-2240) M

SOIL DRAINAGE:

MODERATELY WELL

SLOPE:

$$
25(1-64) \%
$$

ASPECT:

NORTHERLY

Forage Production KG/HA 


\section{ALPA5. Simple bog sedge \\ (Kobresia simpliciuscula)}

$\mathbf{n}=\mathbf{1}$ This community type was described at only one site. Simple bog sedge is typical of boggy areas at higher elevations. This community type was described on a poorly drained, level site at higher elevations. It is likely found in association with the willow and sedge dominated community types found in the valley bottoms of the lower alpine and upper subalpine.

\section{PLANT COMPOSITION CANOPY COVER(\%)} MEAN RANGe CONST.

\section{SHRUBS}

WILLOW SPP.

(Salix spp.)

BOG BIRCH

(Betula glandulosa)

$$
3
$$

100

FORBS

BOG ASPHODEL

(Tofieldia pusilla)

YELLOW MOUNTAIN SAXIFRAGE

(Saxifraga aizoides) 5

SMALL WOOD ANEMONE

(Anemone parviflora) 2

BROAD LEAVED FIREWEED

(Epilobium latifolium) 2

ALPINE BISTORT

(Polygonum viviparum)

\section{Grasses}

SIMPLE BOG SEDGE

(Kobresia simpliciuscula)25 - 100

BALTIC RUSH

(Juncus balticus)

100

100

100

100

\section{ENVIRONMENTAL VARIABLES}

MOISTURE REGIME:

SUBHYGRIC

NUTRIENT REGIME:

PERMESOTROPHIC

ELEVATION:

$1900 \mathrm{M}$

SOIL DRAINAGE:

MODERATELY WELL

Forage Production KG/HA
SUGGESTED GRAZING CAPACITY

NON-USE 


\section{ALPA6. Arctic willow \\ (Salix arctica)}

$\mathbf{n = 2 0}$ This dwarf shrub community occurs in areas of deep snow accumulation, on soils which receive seepage for much of the growing season (Corns and Achuff 1982). Ogilvie (1969), found that there was a rich herb layer of sedges, grasses and forbs and an abundant dwarf shrub layer. This community is similar to the blackening sedge community previously described, but it appears melt out occurs earlier in this community type (Corns and Achuff 1982)

Plant Composition Canopy Cover(\%) Mean Range Const.

SHRUBS

ARCTIC WILLOW .

(Salix arctica)

SNOW WILLOW

(Salix reticulata)

ROCK WILLOW

(Salix vestita)

FORBS

WOOLY EVERLASTING

(Antennaria lanata)

WILD STRAWBERRY

(Fragaria virginiana) $\mathrm{T}$

SMOOTH LEAVED CINQUEFOIL

(Potentilla diversifolia) 1

MOUNTAIN SAGE

(Artemisia norvegica)

ALPINE BISTORT

(Polygonum viviparum) $1 \quad 0-5 \quad 55$

GRASSES

SEDGE

(Carex spp)

HAIRY WILDRYE

(Elymus innovatus) $1 \quad 0-15 \quad 5$

MOUNTAIN TIMOTHY

(Phleum commutatum)

$$
17 \quad 0-50 \quad 80
$$

$4 \quad 0-30 \quad 40$

$6 \quad 0-65 \quad 15$

$7 \quad 0-35 \quad 50$

$0-5 \quad 15$

$0-3 \quad 35$

$0-5 \quad 50$

$0-20 \quad 35$

$0-10 \quad 25$
Forage Production KG/HA

NON-USE

\section{ENVIRONMENTAL VARIABLES}

MOISTURE REGIME:

MESIC TO SUBHYGRIC

NUTRIENT REGIME:

MESOTROPHIC

ELEVATION:

$$
\text { 2141(1830-2330)M }
$$

SOIL DRAINAGE:

MODERATELY WELL TO IMPERFECT

SLOPE:

$$
25(11-58) \%
$$

ASPECT:

VARIABLE 


\section{Literature cited}

Archibald, J.H., G. Klappstein and I.G.W. Corns. 1996. Field guide to ecosites of Southwestern Alberta. Nat. Resour. Can., Can. For. Serv. Northwest Reg., North. For. Cent., Edmonton, AB. Spec rep. no. 8.

Bailey, A.W., M.G. Willoughby, R. Johansen and S. Smith. (1992) Management of Yukon Rangelands. Renewable Resources, Yukon Territorial Government, Whitehorse, Yukon. 55pp. ISBN-1-55018-138-6.

Bork, E. 1990. Clearwater allotment: Prescribed burn vegetation survey, evaluation, and discussion. Range Management Section, Alberta Forest Service, Edmonton, Alta. 29pp.

Bork, E. 1994. Ecological classification and management of native ranges in Willmore Wilderness Park. Range management section, Alberta Environmental Protection. Edmonton, Alta. Pub. no. T/282 65pp.

Beckingham, J., I.G.W. Corns and J.H. Archibald. 1996. Field guide to Ecosites of WestCentral Alberta. Nat. Resour. Can., Can. For. Serv. Northwest Reg., North. For. Cent., Edmonton, AB. Spec rep. no. 9.

Beckingham, J. and J.H. Archibald. 1996. Field guide to ecosites of Northern Alberta. Nat. Resour. Can., Can. For. Serv. Northwest Reg., North. For. Cent., Edmonton, AB. Spec rep. no. 5.

Corns, I.G.W. and P. Achuff. 1982. In Ecological (Biophysical) Land Classification of Banff and Jasper National Parks. Vol II: Soil and Vegetation Resources. Edited by Holland, W.D. and G.M. Coen. Environment Canada and Alberta Institute of Pedology, University of Alberta. Pub. no. SS-82-44. 540pp.

Corns, I.G.W. and R.M. Annas. 1986. Field guide to forest ecosystems of West-Central Alberta. Northern Forestry Center, Canadian Forestry Service, Edmonton, Alta. 251pp.

Daubenmire, R. 1952. Forest vegetation of Northern Idaho and adjacent Washington and its bearing on concepts of vegetation classification. Ecol. Mongr. 22: 301-330.

Department of Environmental Protection. 1994. Natural Regions of Alberta. Alberta Environmental Protection. Edmonton, Alta. Pub. no.: I/531. 18pp.

Gauch, H.G. 1982. Multivariate analysis in community ecology. Cambridge University Press, Cambridge, 298pp. 
Holland, W.D. and G.M. Coen. 1982. Ecological (Biophysical) Land Classification of Banff and Jasper National Parks. Vol II: Soil and Vegetation Resources. Environment Canada and Alberta Institute of Pedology, University of Alberta. Pub. no. SS-82-44. 540pp.

Jaques, D.R. 1976. Winter alpine-subalpine wildlife habitat in the southern Rocky Mountains of Alberta. Kananaskis Center for Environmental Research, University of Calgary. Calgary, Alta. 113pp.

Lane, C.T., M.G.Willoughby and M.J. Alexander. 2000. Range plant community types and Carrying capacity for the Lower Foothills Subregion. $2^{\text {nd }}$ Approximation. Alberta Environment. Land and Forest Service. Edmonton. Pub.no. T/532. 232 pp.

Mackinnon, A., J. Pojar and R. Coupe. 1992. Plants of Northern British Columbia. Lone Pine Publishing, Edmonton, Alta. 345pp.

Mueggler, W.F. 1988. Aspen community types of the Intermountain Region. U.S.D.A. Intermoutain Research Station. INT-250. 133pp.

Morgantini, L. E. and W.B. Russell. 1983. An assessement of three selected elk winter ranges in the Rocky Mountains Region. Alberta Fish and Wildlife Division. Edmonton. AB. 264pp.

Moss, E.H. and J.W. Campbell. 1947. The fescue grassland of Alberta. Can. J. Res. 25:209-227.

Ogilvie, R.T. 1969. The Mountain Forest and Alpine Zones of Alberta. In, Vegetation, Soils and Wildlife. edited by J.G. Nelson and M.J. Chambers. Methuen Publications, Toronto. pg 24-44.

Range Survey Manual. 1992. Range Management Section, Alberta Forest Service. Edmonton, Alta. 39pp.

Scoggan, H.J. 1978. The Flora of Canada. National Museum of Natural Sciences, Publications in Botany, Ottawa, Canada. No. 7(2).

Stringer, P.W.1973. An ecological study of grasslands in Banff, Jasper and Waterton National Parks. Can. J. Bot. Vol. 51. 383-411.

Strong, W.L. 1992. Ecoregions and ecodistricts of Alberta. Vol 1. Alberta Forestry Lands and Wildlife, Land Information Services Division, Resource Information Branch, Edmonton, Alta. T/244. 77pp.

Strong, W.L. and J.M. Thompson. 1995. Ecodistricts of Alberta: Summary of Biophysical 
Attributes. Alberta Environmental Protection, Resource Data Division. Edmonton, Alta. Pub. no. $\mathrm{T} / 319.91 \mathrm{pp}$.

Strong, W.L. and K.R. Leggat. 1992. Ecoregions of Alberta. Alberta Forestry, Lands and Wildlife, Resource Information Branch, Edmonton, Alta. T/245. 77pp.

Wilkinson, K. 1990. Trees and shrubs of Alberta. Lone Pine Publishing. Edmonton. Alta. $191 \mathrm{pp}$.

Willoughby, M.G. 1992. Rangeland Reference Areas, Plant communities, ecology and response to grazing in Division 3. Forestry, Lands and Wildlife, Alberta Forest Service, Edmonton, Alta. Pub. no. T/269. 36pp.

Willoughby, M.G. 1992. Rangeland Reference Areas, Plant communities, ecology and response to grazing in Division 2. Forestry, Lands and Wildlife, Alberta Forest Service, Edmonton, Alta. Pub. no. T/268. 42pp.

Willoughby, M.G. 1998. Rangeland Reference Areas, Seven mile creek range condition and trend from 1953-1994. Environmental Protection, Lands and Forest Service. Edmonton, Alta. Pub. No. T/403. 21 pp.

Willoughby, M.G. 2001. Range plant community types and carrying capacity for the Upper Foothills subregion . $3^{\text {rd }}$ Approximation. Sustainable Resource Development. Public Lands Division, Alta. Pub. no. T/003 120pp.

Willoughby, M.G., M.J. Alexander and B.W. Adams. 2003. Range plant communities and carrying capacity for the Montane subregion. $5^{\text {th }}$ Approximation. Sustainable Resource Development. Public Lands Division. Pub. No. T/033. 223pp. 






\section{2}

